\title{
10. CALCAREOUS NANNOFOSSIL BIOSTRATIGRAPHY: EVIDENCE FOR THRUST FAULTING AND SEDIMENT MIXING IN THE ACCRETIONARY COMPLEX OF THE CENTRAL NEW HEBRIDES ISLAND ARC ${ }^{1}$
}

\author{
T. Scott Staerker ${ }^{2}$
}

\begin{abstract}
Seven sites drilled in the central New Hebrides Island Arc during Ocean Drilling Program Leg 134 yielded varying quantities of upper Eocene through Pleistocene calcareous nannofossils. Most of the Miocene and Pliocene strata were absent from Sites 827-831 drilled along the collisional boundary between the Australia and Pacific plates where the North d'Entrecasteaux Ridge and Bougainville Guyot are being subducted. Sites 832 and 833, drilled in the intra-arc North Aoba Basin, contained upper Miocene through Pleistocene and early Pliocene through Pleistocene nannofossils, respectively. Detailed range charts displaying species abundances and age interpretations are presented for all of the sites.

Despite problems of reworked assemblages, poor preservation, overgrowths and/or dilution from volcaniclastics, the nannofossil biostratigraphy delineates several repeated sections at Site 829 in the accretionary prism adjacent to Espiritu Santo Island. Paleogene pelagic sediments equivalent to those in a reference section at Site 828 appear to have been scraped from the downgoing North d'Entrecasteaux Ridge and accreted onto the forearc during the Pleistocene. Other sediments in the forearc include Pleistocene olistostromal trench-fill deposits containing clasts of various ages and compositions. Some of the clasts and olistoliths have affinities to rocks exposed on the neighboring islands and environs, whereas others are of uncertain origin. The matrix of the olistostromes is predominately Pleistocene, however, matrices of mixed nannofossil ages are frequently encountered. Comparisons of the mixed nannofossil ages in the matrices with sedimentological and structural data suggest that sediment mixing resulting from fault movement is subordinate to that occurring during deposition.
\end{abstract}

\section{INTRODUCTION}

During Ocean Drilling Program (ODP) Leg 134, cores were recovered from seven sites within the central New Hebrides Island Arc located east of the North Fiji Basin (Fig. 1). Although limited core recovery and a paucity of nannofossils across some intervals hindered biostratigraphic interpretation, the bulk of the material recovered on this leg is of significant biostratigraphic value. In conjunction with the other geologic disciplines represented on this cruise, the nannofossil biostratigraphy has increased the understanding of the timing of the major geologic events that have resulted in the present-day configuration of the New Hebrides Island Arc.

The post-cruise scientific investigations for Leg 134 focused on sites in two areas: Sites 827-831, located along the collisional boundary between the Australia-India and the Pacific plates, and Sites 832 and 833, located in the intra-arc North Aoba Basin (NAB) (Fig. 1), Seismic surveys have identified the presence of a curvilinear aseismic bathymetric high, known as the d'Entrecasteaux Zone (DEZ), which is presently being subducted beneath the islands of Espiritu Santo and Malakula (Daniel et al., 1977; Daniel et al., 1986; Collot et al., 1985). Adjacent to these islands the DEZ is characterized by two east-west trending bathymetric features, a ridge called the North d'Entrecasteaux Ridge (NDR) and a seamount chain called the South d'Entrecasteaux Chain (SDC). The relative convergence rate since $0.39 \mathrm{Ma}$ is approximately $13.2 \mathrm{~cm} / \mathrm{yr}$ (Taylor et al., this volume) with the NDR converging slightly oblique to the trench, resulting in a $3.2 \mathrm{~cm} / \mathrm{yr}$ northward translation along the trench (Collot and Fisher, 1991; Taylor et al., this volume). During the early and middle Pleistocene the relative convergence rate was $17.2 \mathrm{~cm} / \mathrm{yr} \pm 7 \mathrm{~cm} / \mathrm{yr}$ with a $4.1 \mathrm{~cm} / \mathrm{yr}$ northward translation of the NDR (Taylor et al., this volume).

\footnotetext{
${ }^{1}$ Greene, H.G., Collot, J.-Y., Stokking, L.B., et al., 1994. Proc. ODP, Sci. Results. 134: College Station, TX (Ocean Drilling Program).

${ }^{2}$ Department of Geology, Florida State University, Tallahassee, FL 32306, U.S.A. (Present address: EA Engineering, Science, and Technology, 1420 Valwood Parkway, Suite 170. Carrollton, TX 75006, U.S.A.)
}

The collision of the DEZ may have influenced the regional tectonics by uplifting the adjacent arc-slope rocks and concomitantly downwarping the NAB (Daniel and Katz, 1981; Burne et al., 1988; Greene et al., 1988; Collot et al., 1985; Collot and Fisher, 1991; Collot, Greene, Stokking, et al., 1992). Deformation along the collisional boundary is not uniform. Relatively little deformation occurred as a result of the impingement of the NDR compared to extensive deformation of the DEZ/arc boundary where the Bougainville Guyot of the SDC collides with the arc (Fisher, 1986; Fisher et al., 1991; Collot, Greene, Stokking, et al., 1992). Despite the greater tectonic deformation evident at the Bougainville Guyot/arc collisional boundary, paleontological and sedimentological shipboard studies conducted on sediments recovered from Hole 829A concluded that numerous repeated geologic sections are present at the NDR/arc collisional boundary (Collot, Greene, Stokking, et al., 1992; Reid et al., this volume; Meschede and Pelletier, this volume.; Collot et al., this volume). Tectono-sedimentary deposits consisting of mixed-age, fractured, chalk-rich breccias were also recovered at Hole $829 \mathrm{~A}$, which suggests that some sediments at the toe of the forearc slope have undergone extensive mass wasting in addition to faulting (Collot, Greene, Stokking, et al., 1992; Reid et al., this volume). Although this paper details the biostratigraphic results from all of the sites drilled during Leg 134, special emphasis is placed on the complex mixture of sediments encountered at Hole 829A.

\section{SCIENTIFIC OBJECTIVES}

The primary objectives of Leg 134 were two fold: (1) to investigate the effects that the composition and morphology of the DEZ have had on the extent of deformation along the collisional front; and (2) to determine the timing of the collision of the DEZ with the arc using data acquired in both the intra-arc NAB and the forearc drill sites (see Greene et al., this volume). Documentation of sediment ages from the Leg 134 holes by means of nannofossil biostratigraphy helped to achieve these objectives by identifying the presence of repeated sections associated with thrust faults in the forearc drill sites and constraining the ages of unconformities recognized from seismic reflection profiles across the NAB. 


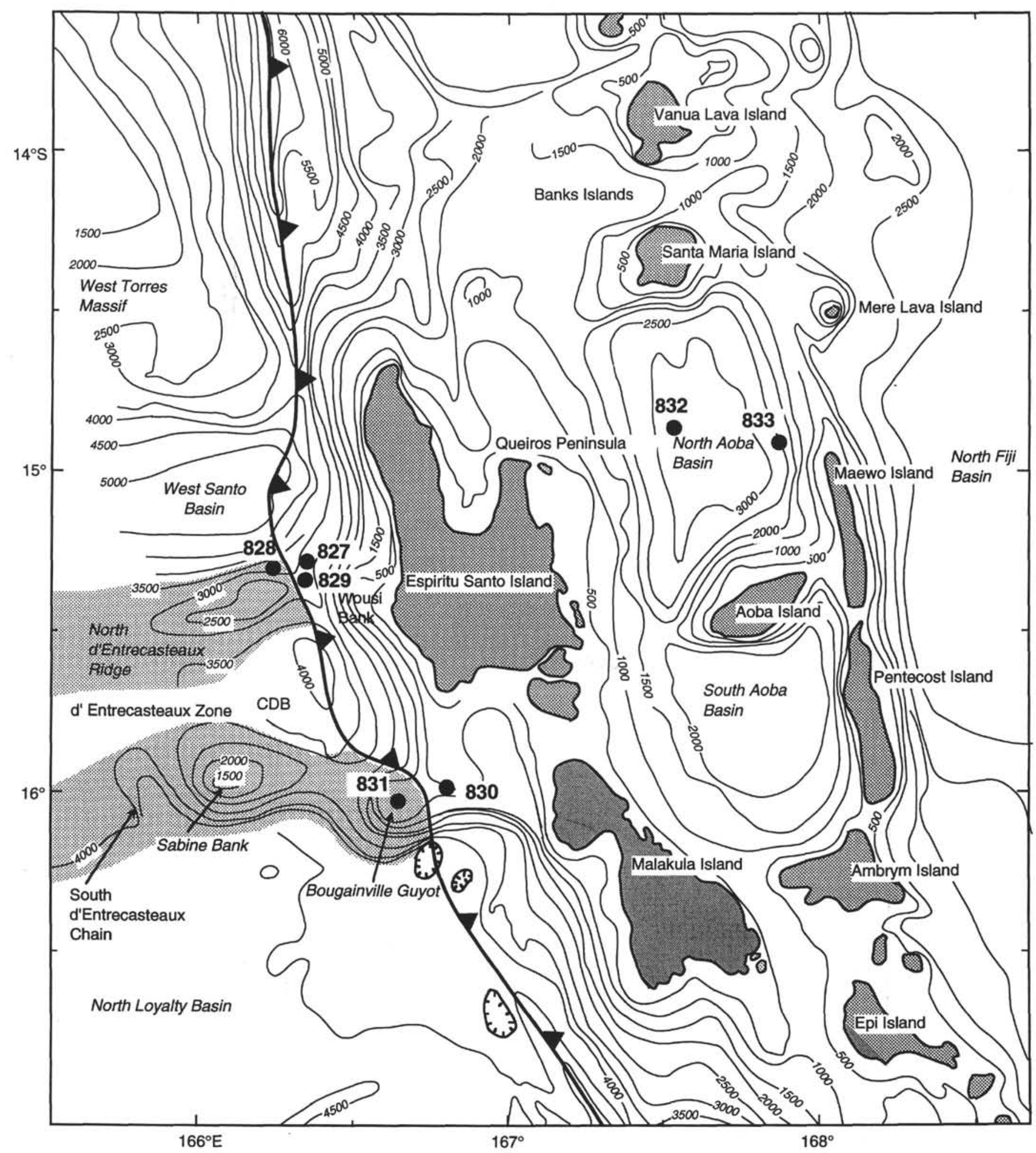

Figure 1. Location of ODP Leg 134 Sites 827 through 833, New Hebrides Island Arc (Vanuatu). Bathymetric contours are in meters. Bold line with triangles indicates plate boundary. Modified from Collot, Greene, Stokking, et al. (1992).

Approximately 1300 samples were taken aboard ship for shorebased nannofossil studies. With the exception of some barren intervals associated with shallow-water carbonates and igneous intrusive rocks, most cores were suitable for nannofossil studies. Nevertheless, some nannofossil assemblages exhibited extensive dissolution, overgrowth, reworking, and/or dilution by volcaniclastics.
To emphasize the biostratigraphic evidence for thrust faulting in the accretionary complex associated with the New Hebrides Island Arc, this study concentrates primarily on the samples from the forearc sites $(827,829$, and 830$)$ and sedimentary reference sections from the NDR (Site 828) and Bougainville Guyot (Site 831). Two sites from the NAB were also studied to record the age of the basin sediments 
and to report the presence of any unconformities. The present study includes the following goals:

1. To use conventional techniques of light and electron microscopy to identify known nannofossil taxa.

2. To place the nannofossils within existing biostratigraphic zonations.

3. To interpret the tectonic and sedimentologic significance of hiatuses, repeated geologic sections, and reworked floral assemblages.

4. To correlate sedimentary units from data acquired on Leg 134 and additional geologic sections from the nearby islands and surrounding environs.

\section{METHODS AND BIOSTRATIGRAPHIC ZONATIONS}

Standard smear slide preparations were used for most of the sediment samples using Norland Optical adhesive \#61 as a mounting medium. Because of the low abundance of nannofossils, settling and centrifuging were required to concentrate samples from Sites 832 and 833. Most taxa identifications were performed using a Zeiss photoscope III at magnifications of approximately $\times 1560$ and $\times 625$. The greater resolution provided by a JEOL JSM840 scanning electron microscope (SEM) was needed to verify datums in the Pleistocene where the nannofossils are extremely small (e.g., Emiliania huxleyi). All data acquired using light microscopy were recorded on species abundance lists and range charts using the paleontological computer program Bugware, provided by its developer, J. Michener Covington of the Florida Geologic Survey.

Abundance estimates of the nannofossils in the smear slides were made on optimum density areas of the slide, that is, areas where most of the field was covered with sample material without appreciable piling of specimens or other material. Estimates of the percentage of total nannofossils present in the sediment were made from smear slides using the following scale:

$$
\begin{aligned}
& A=\text { abundant: }>50 \% \\
& C=\text { common: between } 10 \% \text { and } 50 \% \\
& F=\text { few: between } 1 \% \text { and } 10 \% \\
& R=\text { rare: }<1 \% \\
& B=\text { barren: none }
\end{aligned}
$$

Relative abundances of individual nannofossil species in a given sample are estimated using the method proposed by Hay (1970). Six levels of abundance were recorded as follows:

$$
\begin{aligned}
& H=\text { highly abundant: } 101-1000 \text { specimens per field of view } \\
& V=\text { very abundant: } 11-100 \text { specimens per field of view } \\
& A=\text { abundant: } 1-10 \text { specimens per field of view } \\
& C=\text { common: } 1 \text { specimen per } 2 \text { to } 10 \text { fields of view } \\
& F=\text { few: } 1 \text { specimen per } 11 \text { to } 100 \text { fields of view } \\
& R=\text { rare: } 1 \text { specimen per } 101 \text { to } 1000 \text { fields of view }
\end{aligned}
$$

Calcareous nannofossils commonly show signs of both significant etching and overgrowth; more dissolution-resistant forms add secondary calcite provided by dissolution-prone morphotypes. The following descriptive categories were used to record the various states of preservation observed:

$\mathrm{E}=$ excellent (no evidence of dissolution and/or secondary overgrowth of calcite, with delicate morphological structures fully preserved)

$\mathrm{G}=$ good (minor dissolution and/or secondary overgrowth of calcite, but most morphological characteristics are fully preserved)

$\mathrm{F}=$ fair (dissolution and/or secondary overgrowth partially alter diagnostic morphological characteristics, but nearly all specimens can be identified at the species level)

$\mathrm{P}=$ poor (severe dissolution, fragmentation, and/or secondary overgrowth with primary features largely destroyed; many specimens cannot be identified at the species and/or generic level)
$\mathrm{M}=$ mixed (mixed preservation evident from two or more distinct nannofossil assemblages in the sample)

The zonation schemes of Martini (1971), Gartner (1977), and Okada and Bukry (1980) were used for biostratigraphic determinations with the latter serving as the framework zonation. Since many of the datums used in these zonation schemes have subsequently been correlated with global magnetostratigraphy (Berggren, Kent, and Flynn, 1985; Berggren, Kent, and Van Couvering, 1985), absolute ages for many of the zonal markers have been assigned. The database of combined magnetostratigraphy and biostratigraphy has grown considerably since the Berggren, Kent, and Flynn (1985) and the Berggren, Kent, and Van Couvering (1985) compilations. In an attempt to best represent the current scientific knowledge regarding the consistency of paleontologic age datums, it has been necessary to continually update the absolute ages assigned to the paleontologic datums. The zonation scheme and age assignments for all datums used in this study, including both zonal markers and additional datums, are found in Table 1 and Figure 2. Appendix A presents a discussion of the taxonomic concepts and placement of problematic biostratigraphic datums. Quantitative procedures for delineating the first appearance datum (FAD) of $E$. huxleyi and the last appearance datum (LAD) of $P$. lacunosa in Hole $828 \mathrm{~A}$ are also discussed in Appendix A. Taxa considered in this report are listed in Appendix B.

\section{PREVIOUS STUDIES}

Prior to Leg 134, research in the central New Hebrides Island Arc consisted of land-based mapping of the surface geology of the islands surrounding the Aoba Basin; geophysical surveys conducted by France, the United States, Australia, and New Zealand; and sea-based dredge and grab samples (see Greene et al., 1988; Greene et al., this volume). Detailed bathymetric mapping of the Vanuatu (New Hebrides) area was done by Chase and Seekins (1988). Wide-swath bathymetric mapping using SeaBeam data was performed during both the 1985 SEAPSO (Daniel et al., 1986) and 1987 MULTIPSO (Collot and Fisher, 1989, 1991, 1992) cruises conducted by the Institut Français de Recherche Scientifique pour le Développement en Coopération (ORSTOM).

Results from the SeaBeam investigations suggest that the oblique collision of the NDR with the New Hebrides Island Arc has resulted in a complex tectonic pattern characterized by three distinct structural regimes displayed in the forearc (Fig. 3). Thrust and strike-slip faults are evident north of the collision zone, normal faulting is present to the south, and uplift of the forearc is present at the point of collision (Collot and Fisher, 1991, 1992; Collot et al., 1992).

The first extensive geological sampling of sedimentary rocks from the NDR/Espiritu Santo Island forearc collisional boundary was conducted by the French submersible Nautile during the 1989 SUBPSO 1 cruise (Collot et al., 1989, 1992; Greene et al., 1992). Seven total dives were undertaken along the forearc side of the New Hebrides trench adjacent to Espiritu Santo and Malakula islands (Fig. 4). Four of the dives were conducted in the vicinity of the NDR/forearc collisional boundary adjacent to Espiritu Santo Island. The results of dive 1, which explored the upper slope, indicated lithologies resembling formations that crop out on western Espiritu Santo Island, but dives 2, 3, and 4 located at the toe of the arc slope displayed diverse lithologies (Collot and Fisher, 1992; Collot et al., 1992; Greene et al., 1992). The similarity of the upper arc slope rocks with those exposed on Espiritu Santo Island, together with the trenchward dip of seismic reflectors evident in most of the arc slope examined during the Nautile dives, suggests that the rocks forming most of the arc slope are predominantly of the arc proper and not accreted material (Collot et al., 1989). The exception to the general pattern of trenchward-dipping rocks, however, occurred at the toe of the arc slope along the collisional boundaries of the NDR/ arc and Bougainville Guyot/arc, which suggests that some degree of 
A

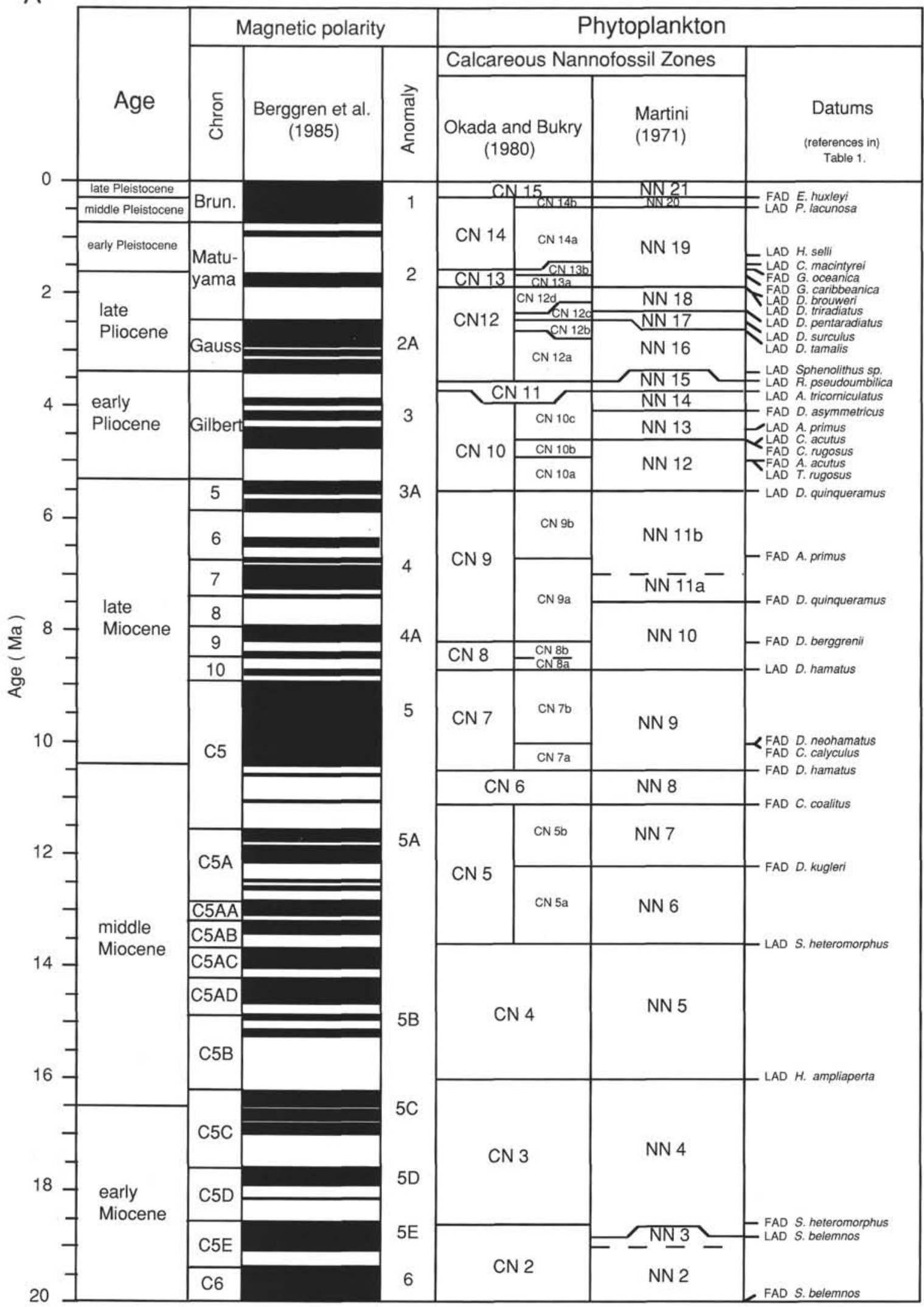

Figure 2. Comparison of nannofossil zones and datums with geomagnetic time scale. Magnetostratigraphic standard is that of Berggren, Kent, Flynn, et al. (1985) and Berggren, Kent, and Van Couvering (1985). The nannofossil datums with corresponding biozones are compiled from the current literature as listed in Table 1. A. 0-20 Ma. B. 20-40 Ma. C. 40-60 Ma. 
B

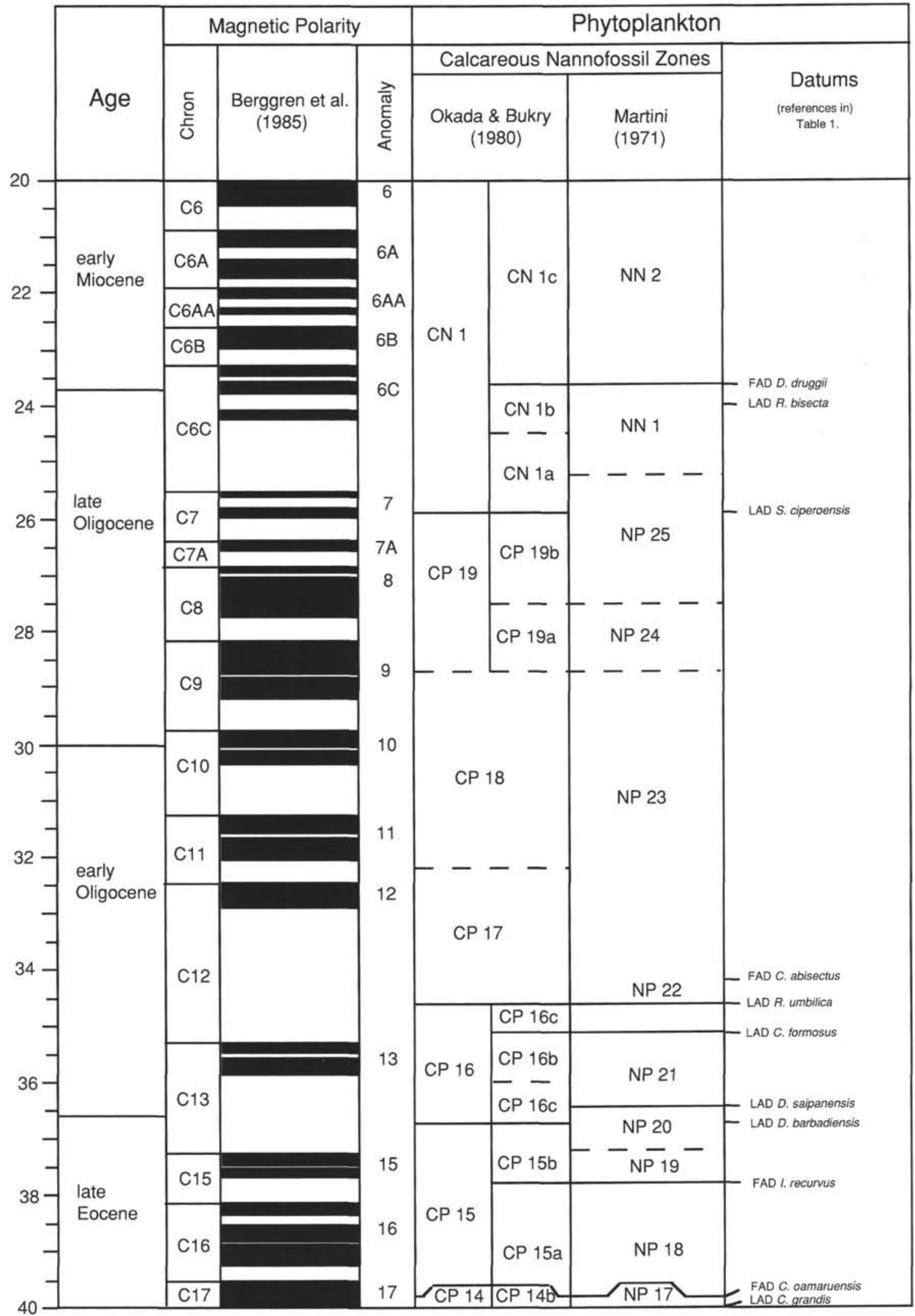

Figure 2 (continued). 


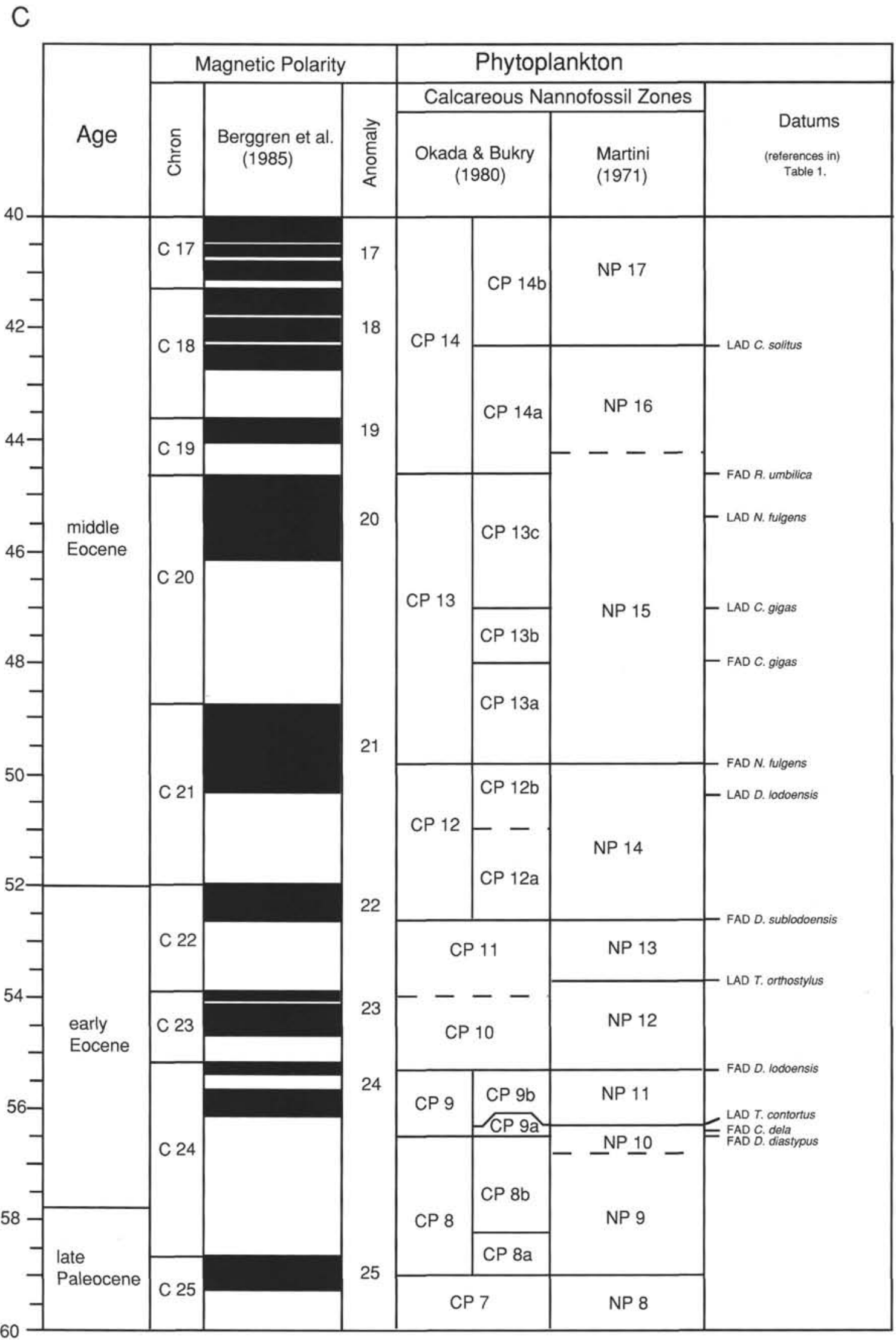

Figure 2 (continued). 
accretion has occurred at these respective localities (Collot et al., 1989, 1992; Collot and Fisher, 1992; Greene et al., 1992).

Nannofossil and foraminiferal analyses were performed on samples recovered by Nautile during the SUBPSO 1 cruise (Collot et al., 1992). Most pertinent to this study are the nannofossil ages interpreted from samples obtained during dives 2-4 along the NDR-Espiritu Santo forearc. These sediments show a great variety in lithology ranging from volcanic-rich calcarenites to nannofossil-rich calcilutites with corresponding ages ranging from latest Pleistocene (NN21) to middle Oligocene (NP23) (Collot et al., 1992; C. Müller, unpubl. data, 1989). Several samples contained assemblages consisting of Oligocene or Miocene species mixed with varying quantities of Quaternary species. Some of these mixed assemblages were interpreted to be from mélange units; however, massive reworking or contamination was suggested for most of the samples containing minor quantities of Quaternary species (C. Müller, unpubl. data, 1989).

Deep Sea Drilling Project (DSDP) Site 286 provides another regional data base to compare with paleontological assemblages from the Leg 134 sites. Drilling at Site 286, in the North Loyalty Basin approximately $130 \mathrm{~km}$ to the south of the NDR (Fig. 1), primarily recovered nannofossil-bearing siltstones and sandstones deposited as turbidites that presumably originated from bathymetric highs located to the north (DEZ) and the west (New Caledonia) (Shipboard Scientific Party, 1975; Klein, 1975). Some nannofossil chalks had also been deposited during intervals of decreased clastic input (Shipboard Scientific Party, 1975).

Although the nannofossil reports from Site 286 record only species presence or absence, age interpretations from this site (Shafik, 1975) can allow correlation of regional unconformities and provide a maximum age for sediments overlying the basaltic basement of the Australia-India plate in this area. The lack of a detailed range chart with abundance estimates does, however, limit comparison of species abundance fluctuations and hinders the correlation of zones between the NDR and the North Loyalty Basin. This is particularly true where reworking has been cited but not differentiated in the range charts.

The most recent and extensive studies to date of the subsurface rocks from the forearc and DEZ were undertaken during the shipboard investigations conducted during Leg 134 (Collot, Greene, Stokking, et al., 1992). Shipboard paleontological studies provided encouraging evidence for thrust-faulted sediment packages within the accretionary complex adjacent to Espiritu Santo Island. Preliminary nannofossil and foraminiferal age determinations delineated several repeated sections, which indicate the existence of imbricate thrusts (Collot, Greene, Stokking, et al., 1992). In addition to the core-catcher samples analyzed aboard ship, approximately 350 samples were collected from cores drilled in the accretionary complex and approximately 250 samples were collected from cores taken from the NDR. These samples were used in the post cruise study to augment the biostratigraphic interpretation established aboard ship.

\section{ONSHORE STRATIGRAPHY}

In addition to the offshore sampling, the geology of the western belt of islands, which includes Espiritu Santo and Malakula islands, has been reported in several New Hebrides Geological Survey publications (Barsdell, 1976; Carney, 1985; Carney and Macfarlane, 1985; Mallick and Greenbaum, 1977; Mitchell, 1966, 1971; Paltech, Pty. Ltd., unpubl. data, 1981; Robinson, 1969; D. Taylor, unpubl. data, 1977). The most recent compilation of geological data from the islands of Espiritu Santo and Malakula were presented by Macfarlane et al. (1988) and is summarized in Figure 5.

The oldest recorded sedimentary rocks from the western belt are exposed only on northwest Malakula Island. These rocks are wellindurated, dark-red to chocolate-brown mudstones with volcanic fragments, interpreted to be of late Oligocene, deep-water origin (Mitchell, 1971; Macfarlane et al., 1988). No microfossils are mentioned from these rocks, which are named the Red Mudstone Formation.
Table 1. Nannofossil datums with references.

\begin{tabular}{|c|c|c|c|}
\hline Event & Species & $\begin{array}{l}\text { Age } \\
\text { (Ma) }\end{array}$ & References \\
\hline FAD & Emiliania huxleyi & 0.28 & 1 \\
\hline LAD & Pseudoemiliania lacunosa & 0.46 & 1 \\
\hline LAD & Helicosphaera sellii & 1.36 & 2 \\
\hline LAD & Calcidiscus macintyrei & 1.45 & 8 \\
\hline FAD & Gephyrocapsa oceanica & 1.58 & 8 \\
\hline LAD & Discoaster brouweri & 1.89 & 3 \\
\hline LAD & Discoaster triradiatus & 1.89 & 3 \\
\hline LAD & Discoaster pentaradiatus & 2.35 & 3 \\
\hline LAD & Discoaster surculus & 2.41 & 3 \\
\hline LAD & Discoaster tamalis & 2.65 & 3 \\
\hline LAD & Sphenolithus spp. & 3.45 & 3 \\
\hline LAD & Reticulofenestra pseudoumbilica & 3.56 & 3 \\
\hline LAD & Amaurolithus tricorniculatus & 3.7 & $6 \mathrm{a}$ \\
\hline FAD & Discoaster asymmetricus & 4.1 & $6 a$ \\
\hline LAD & Amaurolithus primus & 4.4 & $6 a$ \\
\hline FAD & Ceratolithus rugosus & 4.6 & 3 \\
\hline LAD & Ceratolithus acutus & 4.6 & 3 \\
\hline FAD & Ceratolithus acutus & 4.9 & 7 \\
\hline LAD & Triquetrorhabdulus rugosus & 4.9 & 7 \\
\hline LAD & Discoaster quinqueramus & 5.5 & 7 \\
\hline FAD & Amaurolithus primus & 6.7 & 8 \\
\hline FAD & Discoaster quinqueramus & 7.5 & 7 \\
\hline FAD & Discoaster berggrenii & 8.2 & $6 a$ \\
\hline LAD & Discoaster hamatus & 8.7 & 7 \\
\hline FAD & Discoaster neohamatus & 10.0 & 7 \\
\hline FAD & Catinaster calyculus & 10.0 & $6 a$ \\
\hline FAD & Discoaster hamatus & 10.5 & 7 \\
\hline FAD & Catinaster coalitus & 11.1 & 7 \\
\hline FAD & Discoaster kugleri & 12.2 & 7 \\
\hline LAD & Sphenolithus heteromorphus & 13.6 & 7 \\
\hline LAD & Helicosphaera ampliaperta & 16.0 & $6 a$ \\
\hline FAD & Sphenolithus heteromorphus & 18.6 & 7 \\
\hline LAD & Sphenolithus belemnos & 18.8 & 7 \\
\hline FAD & Sphenolithus belemnos & 20.0 & 7 \\
\hline FAD & Discoaster druggii & 23.6 & 7 \\
\hline LAD & Reticulofenestra bisecta & 24.0 & 5 \\
\hline LAD & Sphenolithus ciperoensis & 25.9 & 5 \\
\hline FAD & Cyclocargolithus abisectus & 34.2 & 5 \\
\hline LAD & Reticulofenestra umbilica & 34.6 & $6 b$ \\
\hline LAD & Coccolithus formosus & 35.1 & 5 \\
\hline LAD & Discoaster saipanensis & 36.4 & 5 \\
\hline LAD & Discoaster barbadiensis & 36.7 & $6 \mathrm{~b}$ \\
\hline FAD & Isthmolithus recurvus & 37.8 & $6 \mathrm{~b}$ \\
\hline FAD & Chiasmolithus oamaruensis & 39.8 & $6 \mathrm{~b}$ \\
\hline LAD & Chiasmolithus grandis & 40.0 & $6 \mathrm{~b}$ \\
\hline LAD & Chiasmolithus solitus & 42.3 & $6 \mathrm{~b}$ \\
\hline FAD & Reticulofenestra umbilica & 44.6 & 5 \\
\hline LAD & Nannotetrina fulgens & 45.4 & $6 \mathrm{~b}$ \\
\hline LAD & Chiasmolithus gigas & 47.0 & $6 \mathrm{~b}$ \\
\hline FAD & Chiasmolithus gigas & 48.0 & $6 \mathrm{~b}$ \\
\hline FAD & Nannotetrina fulgens & 49.8 & $6 \mathrm{~b}$ \\
\hline LAD & Discoaster lodoensis & 50.4 & 4 \\
\hline FAD & Discoaster sublodoensis & 52.6 & $6 \mathrm{~b}$ \\
\hline LAD & Tribrachiatus orthostylus & 53.7 & $6 \mathrm{~b}$ \\
\hline FAD & Discoaster iodoensis & 55.3 & $6 \mathrm{~b}$ \\
\hline LAD & Tribrachiatus contortus & 56.3 & $6 b$ \\
\hline FAD & Campylosphaera dela & 56.4 & $6 \mathrm{~b}$ \\
\hline FAD & Discoaster diastypus & 56.5 & $6 b$ \\
\hline
\end{tabular}

Note: $\mathrm{FAD}=$ first-appearance datum; $\mathrm{LAD}=$ last-appearance datum. Legend for references: 1 = Thierstein et al., 1977; 2 = Sato et al., 1991; 3 = Backman and Shackleton, 1983; 4 = Backman, 1986; $5=$ Wei and Wise, 1989; 6a = Berggren, Kent, and Van Couvering, 1985; $6 \mathrm{~b}=$ Berggren, Kent, and Flynn, 1985; 7 = Backman et al., 1990; 8 = Rio et al., 1990.

The oldest rocks from Espiritu Santo Island are upper Oligocene to middle Miocene volcanic breccias and graded vitric sandstones locally containing calcirudite bands and algal-nodule limestones of the Ora Formation (Macfarlane et al., 1988). Calcarenite and calcilutite bands of the Kerewai Division contain lower middle Miocene foraminifers but also contain a shallow-water Eulepidina-Spiroclypeus fauna typical of the Oligocene to lower Miocene (Macfarlane et al., 1988; Mallick and Greenbaum, 1977).

The Pua, Peteao Greywacke, and Pelapa Greywacke Formations are early and middle Miocene in age and represent depositional environments ranging from shallow-water reefal carbonates within portions of the Peteao Greywacke to basinal mudstones, calcirudite, and calcilutites in other portions of the Peteao Greywacke and Pelapa Greywacke Formations. Faunal assemblages from both the Pua and Peteao Greywacke Formations contain Austrotrillina lowchini, 


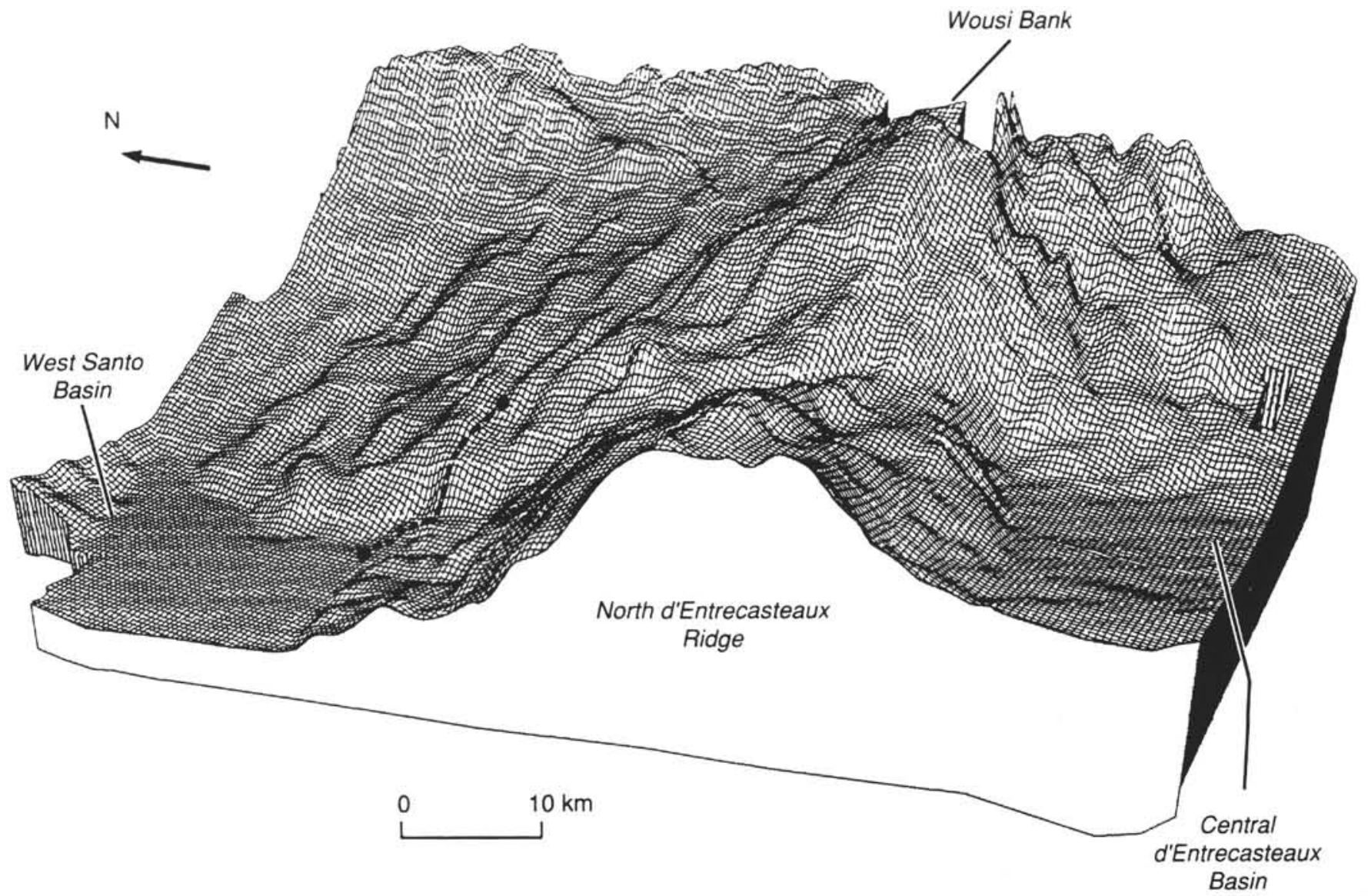

Figure 3. Three-dimensional SeaBeam bathymetry of the forearc/d'Entrecasteaux Zone collisional boundary located adjacent to Espiritu Santo Island in the central New Hebrides Island Arc, Vanuatu. Modified from Collot and Fisher (1991).

which limits these formations to lower middle Miocene foraminiferal Zones N8-N10 (Paltech, Pty. Ltd., unpubl. data, 1981; Macfarlane et al., 1988). The Pelapa Greywacke Formation contains Orbulina suturalis indicating deposition in the lower middle Miocene foraminiferal Zone N9.

Formations deposited during the middle Miocene include the Pialapa Greywacke and Wailapa Formation. The Pialapa Greywacke consists primarily of turbiditic sandstones with interbedded calcirudite and calcarenite bands containing clasts with foraminifers indicative of Zones N9-N10 (Mallick and Greenbaum, 1977). The Wailapa Formation is composed of predominately volcaniclastic breccias and sandstones, turning more calcareous upsection where calcilutites containing middle Miocene age (N11-N14) foraminifers are present (Mallick and Greenbaum, 1977).

Rocks of late Miocene to early Pliocene age exposed on Espiritu Santo Island are placed within the Tawoli Formation and consist of white-gray, recrystallized, well-bedded calcarenites, calcisiltites, and calcilutites of variable degrees of induration (Robinson, 1969; Carney and Macfarlane, 1985; Mallick and Greenbaum, 1977). Abundant foraminiferal concentrations indicate that the Tawoli Formation ranges in age from late Miocene (Zone N17) to early Pleistocene (Zone N22) (Barsdell, 1976; Carney and Macfarlane, 1985; Paltech, Pty. Ltd. unpubl. data, 1979; D. Taylor, unpubl. data, 1977). The Tawoli changes laterally to a predominately calcilutite in its northern and southern exposures on Espiritu Santo Island, where it lies unconformably below the Sale and Navaka Sands Formation (Carney and Macfarlane, 1985).

The Sale and Navaka Sands Formations are primarily shallowwater deposits of late Pliocene to Pleistocene age. The Sale Formation consists of semiconsolidated silts and sands sporadically containing plant debris and shell material (Macfarlane et al., 1988). The Sale
Formation contains foraminifers indicative of Zones N19-N23 which makes it contemporaneous with the lowermost Tawoli Formation. The Navaka Sands Formation, although similar in depositional environment to the Sale Formation, is younger than the Tawoli Formation as the presence of Globorotalia truncatulinoides indicates deposition in the Pleistocene (Mallick and Greenbaum, 1977).

The youngest rocks on Espiritu Santo Island are Pleistocene and Holocene reefal limestones of the Eastern Plateau Limestones. These rocks have been uplifted to a maximum height of $784 \mathrm{~m}$ on eastern Espiritu Santo Island (Macfarlane et al., 1988). Composed of algalcoral biolithites with accompanying forereef and beach deposits, these rocks form terraces that cover much of the eastern and southern parts of Espiritu Santo Island and neighboring Malakula Island (Macfarlane et al., 1988; Taylor, 1992).

\section{BIOSTRATIGRAPHY OF THE DEZ/ARC COLLISION ZONE SITES}

Five sites were drilled within the collision zone between the New Hebrides Island Arc and the DEZ. By drilling a combination of reference sections (Sites 828 and 831) unaffected by compressional deformation and intervals within the deformation front (Sites 827, 829, and 830 ), the degree of accretion and the role compositional and morphological variation has upon deformation can be assessed.

\section{Reference Sections}

\section{Site 828}

Cores from Site 828 (Fig. 1) provide a critical reference section taken from the NDR. Age determinations correlated with lithologic 


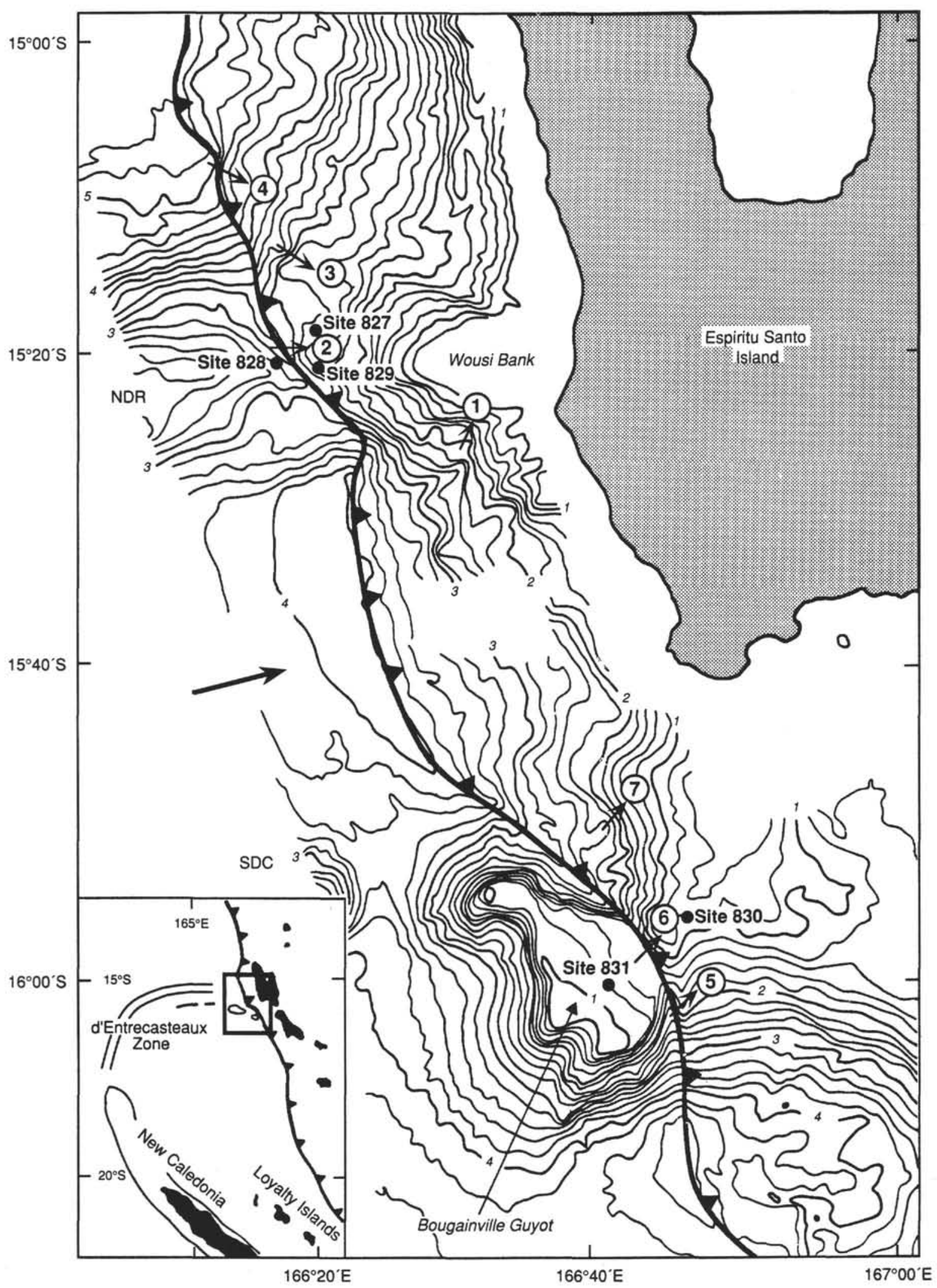

Figure 4. Detailed bathymetry (in kilometers) of the central New Hebrides Island Arc showing transects of dives 1-7 of the submersible Nautile conducted by ORSTOM during the 1987 SEAPSO cruise. Bathymetric contours are in $200 \mathrm{~m}$ intervals. Modified from Daniel et al. (1986). 


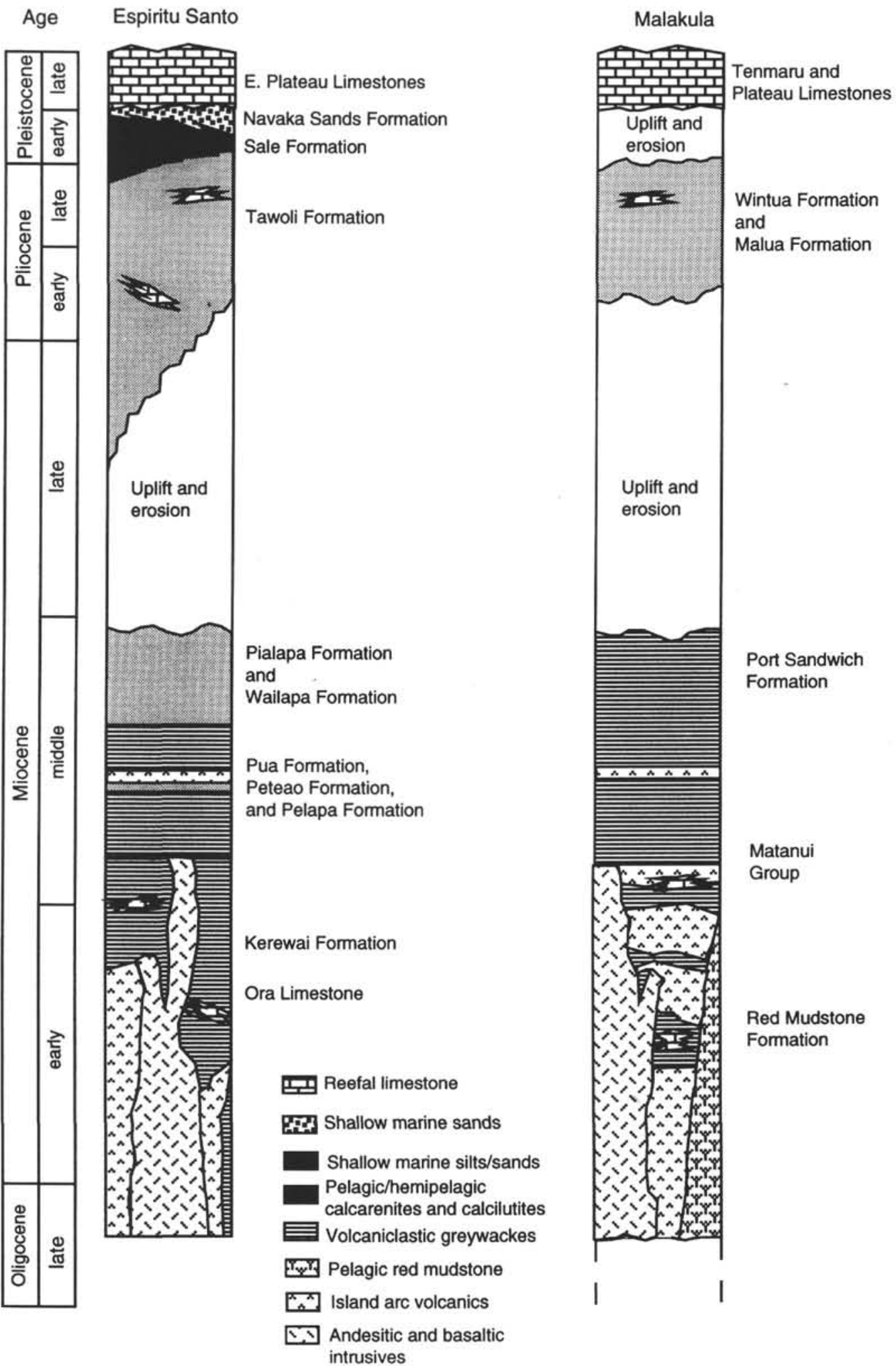

Figure 5. Schematic diagram of the major lithologies and events represented on the islands of Espiritu Santo and Malakula in the central New Hebrides Island Arc. Modified from MacFarlane et al. (1988). 
studies of this site are essential for recognizing biostratigraphically the presence of accreted material along the collision zone at Sites 827 and 829. Questions regarding the timing of the DEZ/arc collision and any consequent tectonic uplift of neighboring Espiritu Santo Island are also addressed from data collected at this site.

There is a significant variation in the age and proportion of nannofossils to volcaniclastic sediments from Site 828 . The calcareous nannofossils range in age from latest Pleistocene to late Eocene (Fig. 6 and Table 2). The sedimentary record is not continuous, however, as indicated by the presence of two prominent unconformities. Across the interval represented by the uppermost unconformity, the lower Pleistocene and upper Pliocene rocks are missing. The second unconformity displays an even more significant loss of section with the lowermost Pliocene, Miocene, and uppermost Oligocene rocks missing. A third more subtle unconformity across which the uppermost Eocene rocks are missing is also interpreted from the nannofossil record at this site.

Pleistocene vitric siltstones comprise the uppermost cores from Hole 828A. The interval from Sample 134-828A-1H, 80-81 cm, through Sample 134-828A-6H-5, 36-37 cm, contains a volumetrically rare but well-preserved nannofossil assemblage typical of the uppermost Pleistocene Zone $\mathrm{CN} 15$, as indicated by the presence of Emiliania huxleyi, Gephyrocapsa oceanica, small and medium gephyrocapsids $(<4 \mu \mathrm{m})$, Rhabdosphaera claviger, Helicosphaera kamptneri, Scapholithus fossilis, Calcidiscus leptoporus, Umbilicosphaera mirabilis, Syracosphaera pulchra, and rare occurrences of Ceratolithus cristatus. Sparse occurrences of the Neogene discoasters Discoaster pentaradiatus, Discoaster brouweri, Discoaster variabilis, and Discoaster quinqueramus are interpreted to be reworked, as are sparse and rare occurrences of Pseudoemiliania lacunosa, Calcidiscus macintyrei, Sphenolithus abies/S. neoabies, and Sphenolithus heteromorphus.

Samples 134-828A-6H-6, 36-37 cm, through 134-828A-7H-4, $39-40 \mathrm{~cm}$, are assigned to upper Pleistocene Zone CN14b. A typical sample consists of $G$. oceanica, small and medium gephyrocapsids $(<4 \mu \mathrm{m}), R$. claviger, $H$. kamptneri, S. fossilis, C. leptoporus, $U$. mirabilis, S. pulchra, and rare occurrences of $C$. cristatus. As with the previously mentioned samples, $P$. lacunosa occurs throughout this sample interval in rare quantities and is considered reworked. Sparse and rare occurrences of Neogene species $D$. pentaradiatus, $D$. brouweri, D. variabilis, D. quinqueramus, Discoaster deflandrei, C. macintyrei, Cyclicargolithus floridanus, Cyclicargolithus abisectus, and $S$. heteromorphus are also considered reworked. Emiliania huxleyi is absent.

Specimens of $P$. lacunosa between Samples 134-828A-7H-5, 59$60 \mathrm{~cm}$, and $134-828 \mathrm{~A}-8 \mathrm{H}-1,28-29 \mathrm{~cm}$, are interpreted to be in situ and indicate that these samples are within the middle to lower Pleistocene (Zone CN14a). The accompanying assemblage is similar to that found uphole. As with all the Pleistocene samples at this site, sparse and rare quantities of reworked nannofossils are present. The reworked species are the same as those previously described from uphole.

The Pleistocene is biostratigraphically complicated owing to the reworking mentioned previously. The shorebased use of sampleenhancement techniques such as particle size separation through settling and centrifuging has, however, resulted in a better quality of microscopic slide than was previously attained aboard ship. Consequently, the placement of two previously uncertain datums during the ship-based study has been revised. The first occurrence of $E$. huxleyi $(0.28 \mathrm{Ma})$ is documented in Sample 134-828A-6H-5, 116-117 cm (SEM sample), whereas the last occurrence of $P$. lacunosa $(0.46 \mathrm{Ma})$ is recorded in Sample 134-828A-7H-5, 59-60 cm (58.49 mbsf).

The next significant change in the microfloral assemblage occurs in Sample 134-828 A-8H-1, 79-80 cm, where lower Pliocene nannofossils indicative of nannofossil Zone CN11 lie disconformably below the previously mentioned middle to lower Pleistocene (CN14a) samples. Between Samples 134-828A-8H-1, 79-80 cm, and 134-
$828 \mathrm{~A}-8 \mathrm{H}-6,26-27 \mathrm{~cm}$, the typical nannofossil assemblage consists of Amaurolithus delicatus, Reticulofenestra pseudoumbilica (>7 $\mu \mathrm{m}), C$. macintyrei, P. lacunosa, $H$. kamptneri, S. abies/S. neoabies, Discoaster asymmetricus, D. pentaradiatus, Coccolithus pelagicus, and C. leptoporus.

Accompanying the change in nannofossil assemblage is a significant change in preservational quality. All of the samples studied from the interval placed in Zone $\mathrm{CN} 11$ are typified by fair preservation with many severely overgrown discoasters. This overgrowth limits the identification of some discoaster species. In addition, the species listed in the range chart have been identified with a higher degree of interpretation than nannofossils from the overlying Pleistocene section, where preservation is excellent. Despite the overgrowth problems, some uniquely shaped taxa such as D. asymmetricus (Pl. 1, Fig. 9 ) and the large five-rayed, bifurcated, and symmetrical $D$. pentaradiatus could be identified with relative certainty (Pl. 1, Fig. 12).

Evidence for a second disconformity, in which all of the Miocene is missing, as well as the lowermost Pliocene and uppermost Oligocene, is supported by the juxtaposition of nannofossil Zones CN11 (Sample 134-828A-8H-6, 26-27 cm) and CP18/17 (Sample 134-828A8 H- $6,112-113 \mathrm{~cm})$. Directly below this disconformity the nannofossil assemblage is typical of the upper to lower Oligocene Zones CP18/17. Between Samples 134-828A-8H-6,112-113 cm, and 134-828A-10H$7,10-11 \mathrm{~cm}$, the dominant nannofossils are Sphenolithus distentus, Sphenolithus predistentus, Dictycoccites bisectus, C. abisectus, C. floridanus, D. deflandrei, and Clausicoccus fenestrata. Rare occurrences of a sphenolith resembling Sphenolithus ciperoensis may suggest that upper Oligocene Zone CP19 also is present.

From Section 134-828A-10H-CC through Sample 134-828A-11H-1, $62-63 \mathrm{~cm}$, a typical lower Oligocene assemblage (Zone CP16c) is indicated by the presence of the marker species Reticulofenestra umbilica together with C. fenestrata, S. predistentus, D. bisectus, C. floridanus, and $D$. deflandrei. Below this sample, the paucity of nannofossils prevents further age determinations.

Although an Eocene age for sediments could not be confirmed in Hole 828A using nannofossils, Sample 134-828B-1R-CC contained an Eocene assemblage (CP15) as indicated by the presence of Discoaster saipanensis and Discoaster barbadiensis. R. umbilica, Ericsonia formosa, D. bisectus, Cribrocentrum reticulatum, Sphenolithus pseudoradians and $C$. floridanus were also observed.

Evidence for a third minor unconformity is indicated by lower Oligocene sediments of Zone CP16b (denoted by the presence of $E$. formosa in the absence of $D$. saipanensis or D. barbadiensis), juxtaposed with the upper Eocene sediments of Zone CP15b containing common occurrences of $D$. barbadiensis and $C$. reticulatum. The presence of $C$. reticulatum (PI. 1, Figs. 1A and 1B) suggests that these samples are not uppermost Eocene. Although the last occurrence of $C$. reticulatum has not been commonly used as a zonal marker, it is widely accepted that the last occurrence of this species lies below the Eocene/ Oligocene boundary (Perch-Nielsen, 1985; Wei and Wise, 1989). The disappearance of both $D$. saipanensis and $C$. reticulatum between Samples 134-828B-1R-5, 35-36 cm, and 134-828B-1R-5, 79-80 cm, would suggest the existence of a short hiatus. A minor lithologic change in the core at $96.65 \mathrm{mbsf}$ further supports the possible presence of an unconformity (Collot, Greene, Stokking, et al., 1992).

Although the framework biostratigraphy created on board ship has been basically confirmed by shore-based analysis, some zonal changes have been made. The recognition of two additional nannofossil datums within the Pleistocene in particular has refined the biostratigraphic interpretation of this problematic, yet significant, interval.

\section{Site 831}

Site 831 was drilled in the center of Bougainville Guyot. The easternmost extension of a seamount chain that forms the southern DEZ (Fig. 1), Bougainville Guyot currently abuts the forearc between 
Table 2. Nannofossil range charts for Site 828.

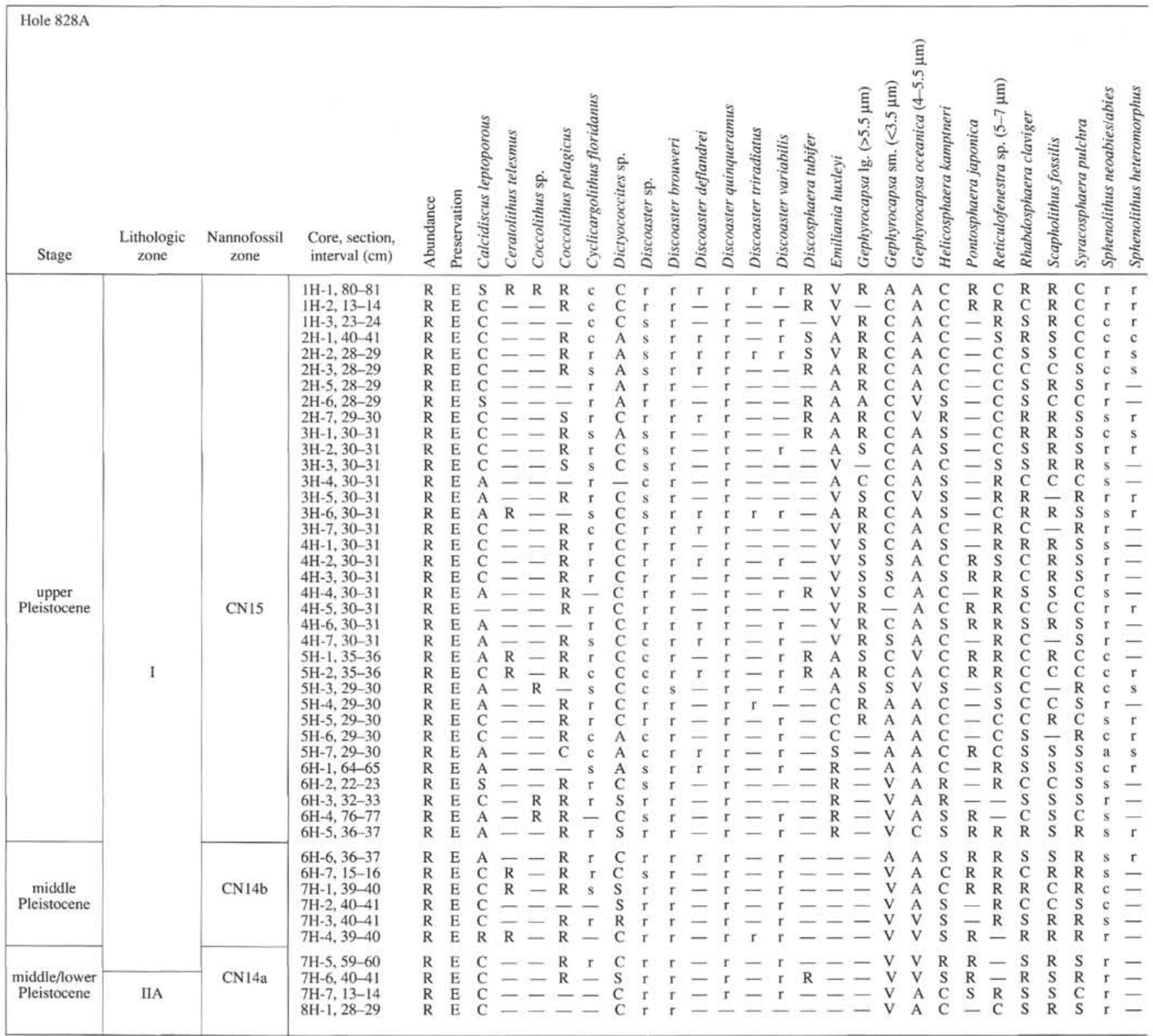

northern Malakula and Espiritu Santo islands. As with Site 828, this site provides a reference section for comparison with sediments recovered from the adjoining forearc.

Only a few cores of Pleistocene pelagic sediments were recovered from Site 831 with the remainder of the cores recovering shallowwater carbonates devoid of nannofossils (Fig. 7 and Table 3). The pelagic interval is of latest Pleistocene age (Zone CN15). The first core contains excellently preserved Emiliania huxleyi, but beginning in Sample 134-831 A-2H-2, 29-30 cm, the samples include a greater micrite and shallow-water carbonate component consisting of tunicate spicules, coral fragments, and other fragmented biogenic calcite grains. This influx of nonpelagic carbonate concomitant with a decrease in volcaniclastics resulted in a diminished preservational state of the nannofossils. This change in preservation is most apparent in E. huxleyi. In the first three sections of Core 134-831A-1H, E. huxleyi is exceptionally well preserved with radially arranged I-bars of the distal shield clearly evident in the light microscope. Below Sample $134-831 \mathrm{~A}-1 \mathrm{H}-3,116-117 \mathrm{~cm}$, specimens of E. huxleyi are difficult to distinguish in the light microscope with the faint halo of I-bars no longer discernable. SEM analysis was required for positive identification below Core 134-831A-1H.

Because the drill site is on a guyot that presumably has been subsiding constantly throughout the Quaternary (Dubois et al., 1988; Collot, Greene, Stokking, et al., 1992), the enhanced preservation of the nannofossils in the uppermost cores, despite increasing water depth, must be the result of decreasing in-situ diagenesis. The influx of volcaniclastics during the latest Pleistocene and Holocene, coincident with a diminished input of the shallow-water carbonate component, resulted in less dissolution of the fragile nannofossils such as $E$. huxleyi.

\section{Forearc Drill Sites}

Sites 827 and 829 are located within the collision zone of the DEZ where the NDR abuts the arc-slope adjacent to Espiritu Santo Island. The objectives for drilling these sites include determining the lithology, composition, and age of the rocks to estimate the timing of the arc/ridge collision and the amount of accreted material originating from the Australia-India Plate. Nannofossil biostratigraphy is instru- 


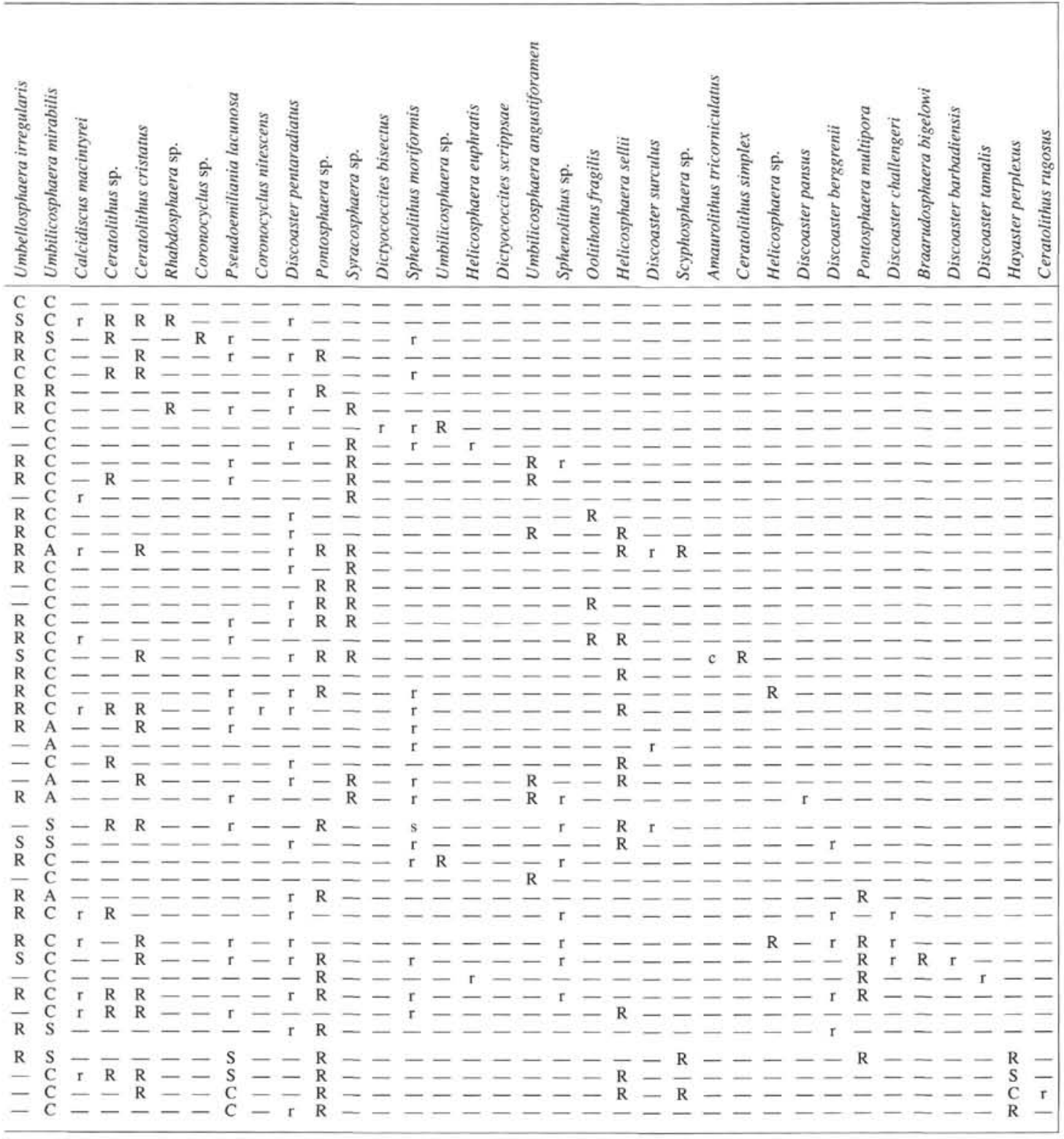

mental in interpreting the ages and stratigraphic relationships of the sediments; however, sedimentological and structural complexities inhibited the preliminary shipboard analyses. Extensive sediment reworking within the Pleistocene and Pliocene intervals prevented the shipboard application of zonation schemes that rely upon last-appearance datums (LADs). During shore-based analyses, reworking has been dealt with in the same manner as described for Site 828 . The creation of detailed species range charts, based on qualitative abundance estimates, provides the criterion by which to distinguish between in-situ and displaced specimens. Despite the availability of abundance profiles, the placement of last-occurrence datums throughout the Pleistocene and upper Pliocene was more subjective than in less clastic-rich, pelagic sediments.

\section{Site 827}

Detailed shore-based evaluation of calcareous nannofossils from Site 827 indicates a continuous biostratigraphic record over most of the section drilled in Holes 827A and 827B (Fig. 8 and Table 4).
Sediments range in age from the latest Pleistocene (Zone $\mathrm{CN} 15$ ), starting in Sample 134-827 A-1H-1, 17-18 cm, through late Pliocene (Zone CN12c), which is last recorded in Sample 134-827B-15R-2, $107-108 \mathrm{~cm}$. Below this, a recurrence of Gephyrocapsa oceanica indicates that between Samples 134-827B-15R-2, 107-108 cm, and the last sample analyzed in this hole, Sample 134-827B-15R-6, 55-56 $\mathrm{cm}$, there exists an inversion of age relationships in which upper Pliocene sediments overlie middle to lower Pleistocene sediments. The repeated section, resulting from the juxtaposition of nannofossil Zone CN12c over CN14a at approximately 246 mbsf, is coincident with a structurally defined shear zone between 230 and $250 \mathrm{mbsf}$ (Meschede and Pelletier, this volume; Collot, Greene, Stokking, et al., 1992). Results of both independent studies indicate that a thrust fault was encountered.

In addition to the zonal inversion, shore-based analyses indicate several previously unnoticed nannofossil datums within the Pleistocene and upper Pliocene. The presence of Emiliania huxleyi is documented from Samples $827 \mathrm{~A}-1 \mathrm{H}-1,17-18 \mathrm{~cm}$, through $827 \mathrm{~B}-1 \mathrm{R}$, $10-11 \mathrm{~cm}$. This revised placement of the first appearance datum 
Table 2 (continued).

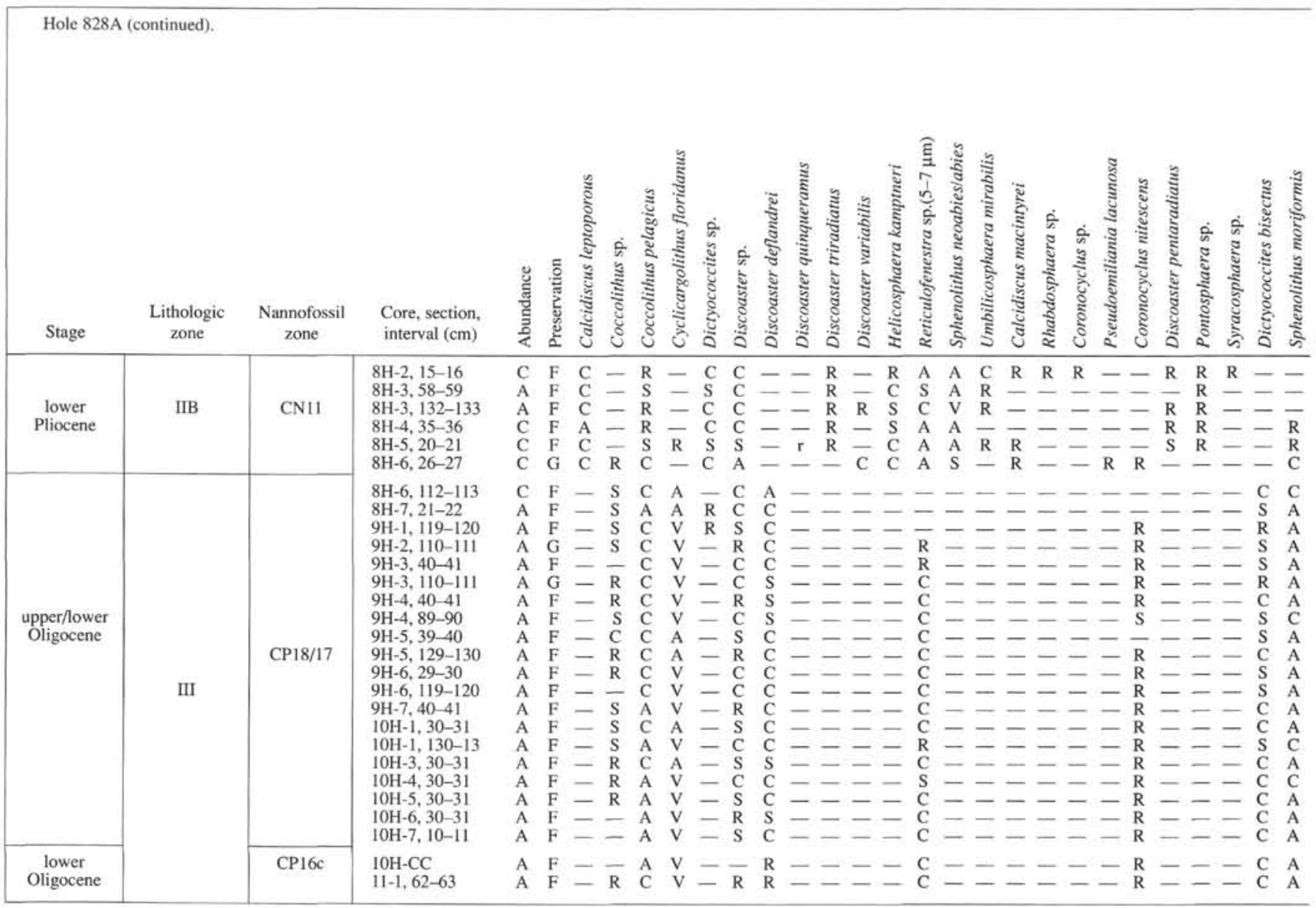

Table 2 (continued).

\begin{tabular}{|c|c|c|c|c|c|c|c|c|c|c|c|c|c|c|c|c|c|c|c|c|c|c|c|c|}
\hline \multicolumn{25}{|l|}{ Hole $828 \mathrm{~B}$} \\
\hline Stage & $\begin{array}{l}\text { Lithologic } \\
\text { zone }\end{array}$ & $\begin{array}{l}\text { Nannofossil } \\
\text { zone }\end{array}$ & $\begin{array}{l}\text { Core, section, } \\
\text { interval }(\mathrm{cm})\end{array}$ & 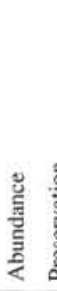 & 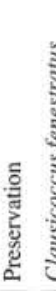 & 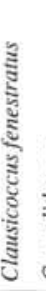 & 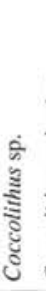 & 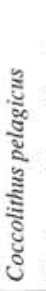 & 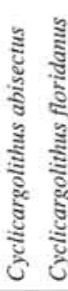 & 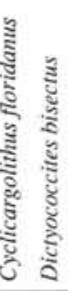 & 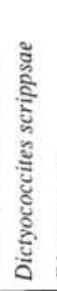 & 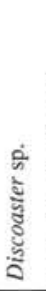 & 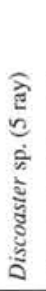 & 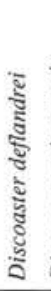 & 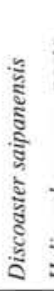 & 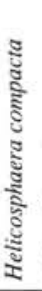 & 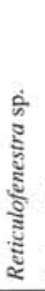 & 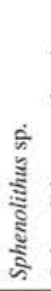 & 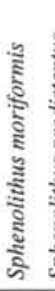 & 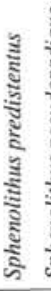 & 气ू & 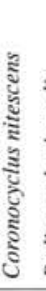 & 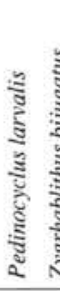 & 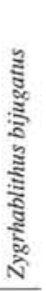 \\
\hline \multirow{2}{*}{$\begin{array}{l}\text { lower } \\
\text { Oligocene }\end{array}$} & \multirow{3}{*}{ III } & CP16c & $\begin{array}{l}\text { IR-1 33-34 } \\
\text { IR-2,94-95 } \\
\text { IR-3, 25-26 } \\
\text { IR-3,90-91 }\end{array}$ & $\begin{array}{l}\text { A } \\
\text { A } \\
\text { A } \\
\text { A }\end{array}$ & $\begin{array}{l}\mathrm{F} \\
\mathrm{F} \\
\mathrm{F} \\
\mathrm{F}\end{array}$ & $\begin{array}{l}\mathrm{S} \\
\mathrm{R} \\
\mathrm{S} \\
\mathrm{C}\end{array}$ & $\begin{array}{l}S \\
R \\
R \\
S\end{array}$ & $\begin{array}{l}\text { A } \\
\text { A } \\
\text { A } \\
\text { A }\end{array}$ & $\begin{array}{ll}C & V \\
R & V \\
- & V \\
- & V\end{array}$ & $\begin{array}{ll}\text { V } & R \\
\text { V } & C \\
\text { V } & C \\
\text { V } & C\end{array}$ & $\begin{array}{l}\mathrm{R} \\
\mathrm{R} \\
\mathrm{S} \\
\mathrm{R}\end{array}$ & $\begin{array}{l}R \\
S \\
R \\
S\end{array}$ & $\begin{array}{l}\mathrm{R} \\
\mathrm{R} \\
\mathrm{R} \\
\mathrm{R}\end{array}$ & $\begin{array}{l}\mathrm{R} \\
\mathrm{R} \\
\mathrm{R} \\
-\end{array}$ & $\frac{\mathrm{R}}{Z}$ & $\begin{array}{l}\mathrm{R} \\
\mathrm{R} \\
\mathrm{R} \\
\mathrm{R}\end{array}$ & $\begin{array}{l}\text { C } \\
\text { C } \\
\text { A } \\
\text { C }\end{array}$ & $\begin{array}{l}\text { A } \\
\text { C } \\
\text { C } \\
\text { S }\end{array}$ & $\begin{array}{l}\text { A } \\
\text { A } \\
\text { A } \\
\text { A }\end{array}$ & $\begin{array}{ll}\mathrm{A} & \mathrm{F} \\
\mathrm{A} & \mathrm{H} \\
\mathrm{A} & \mathrm{F} \\
\mathrm{C} & \mathrm{H}\end{array}$ & $\begin{array}{l}\mathrm{R} \\
\mathrm{R} \\
\mathrm{R} \\
\end{array}$ & $\frac{-}{\bar{R}}$ & $\begin{array}{ll}- & - \\
R & F \\
R & \end{array}$ & $\begin{array}{l}\bar{R} \\
\mathrm{R} \\
\end{array}$ \\
\hline & & CP16b & $\begin{array}{l}\text { IR-4, 55-56 } \\
\text { IR-4, 121-122 } \\
\text { IR-5, 35-36 }\end{array}$ & $\begin{array}{l}\mathrm{A} \\
\mathrm{A} \\
\mathrm{A}\end{array}$ & $\begin{array}{l}F \\
F \\
F\end{array}$ & $\begin{array}{l}\text { C } \\
\text { C } \\
\text { S }\end{array}$ & $\begin{array}{l}S \\
R \\
R\end{array}$ & $\begin{array}{l}\text { A } \\
\text { A } \\
\text { A }\end{array}$ & $\begin{array}{l}-\mathrm{v} \\
=\mathrm{A} \\
-\mathrm{V}\end{array}$ & $\begin{array}{ll}\text { V } & \text { C } \\
\text { A } & \text { C } \\
\text { V } & \text { C }\end{array}$ & $\begin{array}{l}\mathrm{S} \\
\mathrm{S} \\
\mathrm{C}\end{array}$ & $\begin{array}{l}\mathrm{S} \\
\mathrm{R} \\
\mathrm{R}\end{array}$ & $\begin{array}{l}\mathrm{R} \\
\mathrm{R} \\
\end{array}$ & $\begin{array}{l}\mathrm{R} \\
\mathrm{R} \\
\mathrm{R}\end{array}$ & $=$ & $\begin{array}{l}\mathrm{R} \\
\mathrm{R} \\
\mathrm{C}\end{array}$ & $\begin{array}{l}\mathrm{C} \\
\mathrm{C} \\
\mathrm{C}\end{array}$ & $\begin{array}{l}\mathrm{C} \\
\mathrm{C} \\
\mathrm{S}\end{array}$ & $\begin{array}{l}\mathrm{A} \\
\mathrm{A} \\
\mathrm{A}\end{array}$ & $\begin{array}{ll}\mathrm{C} & - \\
\mathrm{C} & \mathrm{F} \\
\mathrm{C} & \mathrm{F}\end{array}$ & $\begin{array}{l}\mathrm{R} \\
\mathrm{R}\end{array}$ & $\begin{array}{l}\overline{\mathrm{R}} \\
\mathrm{R}\end{array}$ & $\begin{array}{ll}R & F \\
R & F \\
R & \end{array}$ & $\begin{array}{l}\mathrm{R} \\
\mathrm{R} \\
\end{array}$ \\
\hline $\begin{array}{l}\text { upper } \\
\text { Eocene }\end{array}$ & & CP15b & $\begin{array}{l}\text { IR-5, 79-80 } \\
\text { IR-5, 91-92 } \\
\text { IR-5, 94-95 } \\
\text { IR-5, 99-101 } \\
\text { IR-CC }\end{array}$ & $\begin{array}{l}\mathrm{A} \\
\mathrm{A} \\
\mathrm{A} \\
\mathrm{A} \\
\mathrm{A}\end{array}$ & $\begin{array}{l}\mathrm{G} \\
\mathrm{F} \\
\mathrm{G} \\
\mathrm{F} \\
\mathrm{F}\end{array}$ & $\frac{\bar{R}}{\mathrm{~A}}$ & $\frac{\bar{c}}{\bar{s}}$ & $\begin{array}{l}\mathrm{A} \\
\mathrm{A} \\
\mathrm{A} \\
\mathrm{A} \\
\mathrm{A}\end{array}$ & $\begin{array}{l}=\bar{A} \\
=\bar{v} \\
-\end{array}$ & $\begin{array}{ll} & \text { S } \\
\text { A } & \text { S } \\
& \text { C } \\
\text { V } & \text { C } \\
\text { A } & \text { A }\end{array}$ & $\begin{array}{l}\mathrm{S} \\
\mathrm{R} \\
\mathrm{R} \\
\mathrm{C}\end{array}$ & $\frac{\bar{c}}{\bar{c}}$ & $\begin{array}{l}\mathrm{S} \\
\mathrm{C} \\
\mathrm{C} \\
\mathrm{R} \\
\mathrm{S}\end{array}$ & $\frac{\bar{z}}{\overline{\mathrm{R}}}$ & $\begin{array}{l}\text { C } \\
\text { S } \\
\text { C } \\
\text { C }\end{array}$ & $\begin{array}{l}R \\
R \\
S \\
R\end{array}$ & $\frac{\bar{A}}{\bar{C}}$ & $\begin{array}{l}\mathrm{S} \\
\mathrm{C} \\
\mathrm{S} \\
\mathrm{R}\end{array}$ & $\begin{array}{l}\text { C } \\
\text { C } \\
\text { A } \\
\text { A } \\
\text { A }\end{array}$ & $\begin{array}{ll}\mathrm{R} & \mathrm{F} \\
\mathrm{R} & - \\
\mathrm{R} & - \\
\mathrm{R} & \mathrm{F} \\
- & \end{array}$ & R & $\begin{array}{l}\mathrm{R} \\
\mathrm{R} \\
\mathrm{R} \\
\mathrm{S} \\
\mathrm{R} \\
-\end{array}$ & $\frac{\bar{R}}{\mathrm{R}}-$ & $\begin{array}{l}\bar{z} \\
\bar{z}\end{array}$ \\
\hline
\end{tabular}


Table 2 (continued).

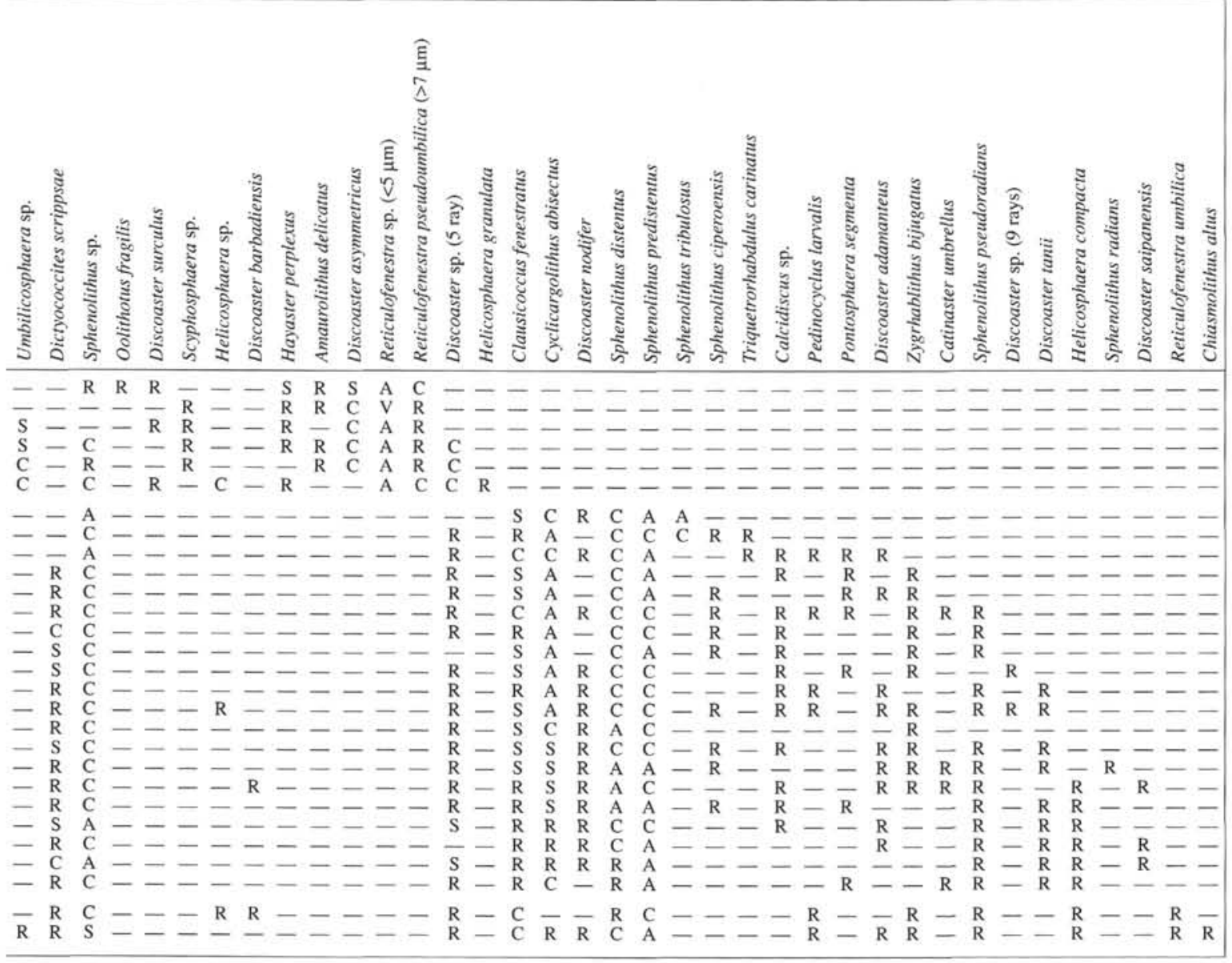

Table 2 (continued).

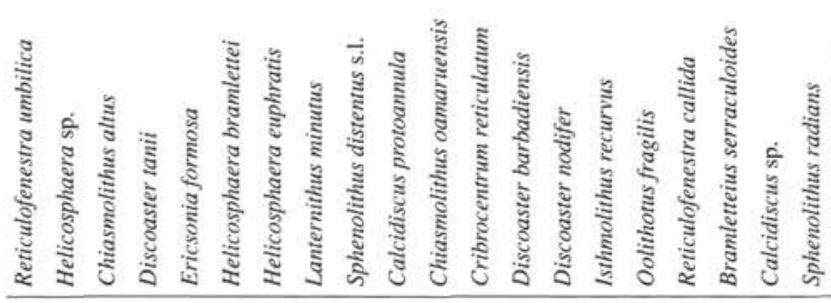

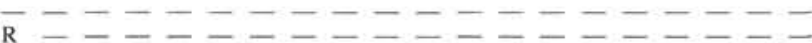

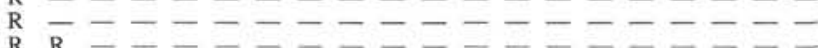

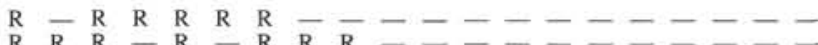

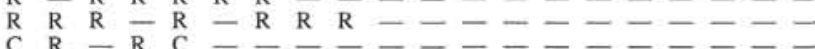
$\begin{array}{lllllllllllllllll}\mathrm{C} & \mathrm{R} & - & \mathrm{C} & - & - & - & \mathrm{S} & \mathrm{S} & \mathrm{C} & \mathrm{R} & \mathrm{R} & \mathrm{S} & \mathrm{R} & - & - & -\end{array}$ $\frac{R}{R}--\mathrm{C}---\ldots \mathrm{S}$ A $\mathrm{C}-\mathrm{R}$ S C S S S

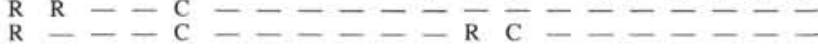

(FAD) of E. huxleyi ( $0.28 \mathrm{Ma})$, which denotes the boundary between Zones CN15 and CN14, is located approximately $23 \mathrm{~m}$ farther downsection than previously determined aboard ship. The LAD of Pseudoemiliania lacunosa (0.46 Ma), located in Sample 134-827B-4R-3, 11-12 cm, and the last occurrence of Calcidiscus macintyrei, recorded in Sample 134-827B-10R-4, 43-44 cm, were both recognized only after shorebased analysis. As with the FAD of E. huxleyi $(0.28$ $\mathrm{Ma})$, the first occurrence of $G$. oceanica $(1.58 \mathrm{Ma})$ has been moved downsection to Sample 134-827B-11R-3, 30-31 cm. The previously undocumented last occurrences of Discoaster triradiatus and Discoaster pentaradiatus are recorded in Samples 134-827B-13R-2, $10-11 \mathrm{~cm}$ (225.30 mbsf), and 134-827B-13R-4, 22-23 cm, respectively, indicating that these samples are of late Pliocene age.

Owing to considerable reworking, which hindered accurate placement of the LADs aboard ship, the precision with which these newly described datums can be applied is still uncertain. All of the samples have been studied only in a qualitative manner with species abundances estimated rather than using the more quantitative but timeconsuming approach involving counts. Despite the lack of quantitative analysis to differentiate between the in-situ zonal markers from displaced specimens, the placement of $C$. macintyrei is made with a high degree of confidence. The drastic change in abundance of this species across the purported zonal boundary at 199.63 mbsf suggests strongly that the specimens below this point are in situ, whereas those above are likely to be reworked.

The same degree of confidence is not held regarding the placement of the LADs of Discoaster brouweri and D. pentaradiatus. Discoaster brouweri and D. pentaradiatus are sparse to rare even in the youngest cores, making their placement difficult. The strongest 


\begin{tabular}{|c|c|c|c|c|c|}
\hline \multirow[t]{2}{*}{ Age } & \multicolumn{2}{|c|}{ Zone } & \multirow{2}{*}{$\begin{array}{l}\text { Core, section, } \\
\text { interval }(\mathrm{cm})\end{array}$} & \multirow{2}{*}{$\begin{array}{l}\text { Depth } \\
\text { (mbsf) }\end{array}$} & \multirow{2}{*}{ Datum } \\
\hline & (Okada and Bukry, 1980) & (Martini, 1971) & & & \\
\hline $\begin{array}{l}\text { late } \\
\text { Pleistocene }\end{array}$ & CN15 & NN21 & $\begin{array}{l}1 \mathrm{H}-1,80-81 \\
1 \mathrm{H}-2,13-14 \\
1 \mathrm{H}-3,23-24 \\
2 \mathrm{H}-1,40-41 \\
6 \mathrm{H}-3,32-33 \\
6 \mathrm{H}-4,76-77 \\
6 \mathrm{H}-5,36-37\end{array}$ & $\begin{array}{l}0.80-0.81 \\
1.63-1.64 \\
3.23-3.24 \\
4.80-4.81 \\
45.72-45.73 \\
47.66-47.67 \\
48.76-48.77\end{array}$ & $\overbrace{\text { FAD E. huxleyi }}^{40.91 \mathrm{~m}}$ \\
\hline $\begin{array}{l}\text { middle } \\
\text { Pleistocene }\end{array}$ & CN14b & NN20 & $\begin{array}{l}6 \mathrm{H}-6,36-37 \\
6 \mathrm{H}-7,15-16 \\
7 \mathrm{H}-1,39-40 \\
7 \mathrm{H}-2,40-41 \\
7 \mathrm{H}-3,40-41 \\
7 \mathrm{H}-4,39-40\end{array}$ & $\begin{array}{l}50.26-50.27 \\
51.55-51.56 \\
52.29-52.30 \\
53.80-53.81 \\
55.30-55.31 \\
56.79-56.80\end{array}$ & LAD P. lacunosa \\
\hline $\begin{array}{l}\text { middle to early } \\
\text { Pleistocene }\end{array}$ & CN14a & NN19 & $\begin{array}{l}7 \mathrm{H}-5,59-60 \\
7 \mathrm{H}-6,40-41 \\
7 \mathrm{H}-7,13-14 \\
8 \mathrm{H}-1,28-29 \\
\end{array}$ & $\begin{array}{l}58.49-58.50 \\
59.80-59.81 \\
61.03-61.04 \\
61.68-61.69 \\
\end{array}$ & .....Unconformity.... \\
\hline $\begin{array}{l}\text { early } \\
\text { Pliocene }\end{array}$ & CN11 & NN15 & \begin{tabular}{l|}
$8 \mathrm{H}-1,79-80$ \\
$8 \mathrm{H}-2,15-16$ \\
$8 \mathrm{H}-3,132-133$ \\
$8 \mathrm{H}-4,35-36$ \\
$8 \mathrm{H}-5,20-21$ \\
$8 \mathrm{H}-6,26-27$ \\
\end{tabular} & $\begin{array}{l}62.19-62.20 \\
63.05-63.06 \\
65.72-65.73 \\
66.25-66.26 \\
67.60-67.61 \\
69.16-69.17 \\
\end{array}$ & ....Unconformity... \\
\hline $\begin{array}{l}\text { early to late } \\
\text { Oligocene }\end{array}$ & CP18/CP17 & NP23 & $\begin{array}{l}8 \mathrm{H}-6,112-113 \\
8 \mathrm{H}-7,21-22 \\
9 \mathrm{H}-1,119-120 \\
9 \mathrm{H}-2,29-30 \\
9 \mathrm{H}-2,110-111 \\
9 \mathrm{H}-3,40-41 \\
9 \mathrm{H}-3,110-111 \\
9 \mathrm{H}-4,40-41 \\
9 \mathrm{H}-4,89-90 \\
9 \mathrm{H}-5,39-40 \\
9 \mathrm{H}-5,129-130 \\
9 \mathrm{H}-6,29-30 \\
9 \mathrm{H}-6,119-120 \\
9 \mathrm{H}-7,40-41 \\
10 \mathrm{H}-1,30-31 \\
10 \mathrm{H}-1,130-131 \\
10 \mathrm{H}-2,30-31 \\
10 \mathrm{H}-3,30-31 \\
10 \mathrm{H}-4,30-31 \\
10 \mathrm{H}-5,30-31 \\
10 \mathrm{H}-6,30-31 \\
10 \mathrm{H}-7,10-11\end{array}$ & $\begin{array}{l}70.02-70.03 \\
70.61-70.62 \\
72.09-72.10 \\
72.69-72.70 \\
73.50-73.51 \\
74.30-74.31 \\
75.00-75.01 \\
75.80-75.81 \\
76.29-76.30 \\
77.29-77.30 \\
78.19-78.20 \\
78.69-78.70 \\
79.59-75.60 \\
80.30-80.31 \\
80.70-80.71 \\
81.70-81.71 \\
82.20-82.21 \\
83.70-83.71 \\
85.20-85.21 \\
86.70-86.71 \\
88.20-88.21 \\
89.50-89.51\end{array}$ & LAD R. umbilica \\
\hline $\begin{array}{l}\text { early } \\
\text { Oligocene }\end{array}$ & CP16c & NP22 & $\begin{array}{l}10 \mathrm{H}-\mathrm{CC} \\
11 \mathrm{H}-1,62-63\end{array}$ & $\begin{array}{l}89.89-89.90 \\
90.52-90.53\end{array}$ & 34.6 Ma \\
\hline
\end{tabular}

B

\begin{tabular}{|c|c|c|c|c|c|}
\hline Age & \multicolumn{2}{|c|}{ Zone } & $\begin{array}{l}\text { Core, section, } \\
\text { interval }(\mathrm{cm})\end{array}$ & $\begin{array}{l}\text { Depth } \\
\text { (mbsf) }\end{array}$ & Datum \\
\hline \multirow[t]{2}{*}{$\begin{array}{l}\text { early } \\
\text { Oligocene }\end{array}$} & CP16c & NP22 & $\begin{array}{l}1 \mathrm{R}-1,33-34 \\
1 \mathrm{R}-1,101-102 \\
1 \mathrm{R}-2,94-95 \\
1 \mathrm{R}-3,25-26 \\
1 \mathrm{R}-3,90-91\end{array}$ & \begin{tabular}{|l|}
$90.33-90.34$ \\
$91.10-91.11$ \\
$92.44-92.45$ \\
$93.25-93.26$ \\
$93.90-93.91$ \\
\end{tabular} & LAD E. formosa \\
\hline & CP16b & NP21 & $\begin{array}{l}1 \mathrm{R}-4,55-56 \\
1 \mathrm{R}-4,121-122 \\
1 \mathrm{R}-5,35-36\end{array}$ & \begin{tabular}{|l|}
$95.05-95.06$ \\
$95.71-95.72$ \\
$96.35-96.36$ \\
\end{tabular} & .... Unconformity?.... \\
\hline $\begin{array}{l}\text { late } \\
\text { Eocene }\end{array}$ & CP15b & NP19/20 & $\begin{array}{l}\text { 1R-5, } 79-80 \\
1 \mathrm{R}-5,91-92 \\
1 \mathrm{R}-5,94-95 \\
1 \mathrm{R}-\mathrm{CC}\end{array}$ & \begin{tabular}{|l|}
$96.79-96.80$ \\
$96.91-96.92$ \\
$96.94-96.96$ \\
$99.99-100.00$
\end{tabular} & $\begin{array}{l}\text { LAD D. saipanensis } \\
\text { LAD C. reticulatum }\end{array}$ \\
\hline
\end{tabular}

Figure 6. Nannofossil biostratigraphic summary. A. Hole 828A. B. Hole 828B. 


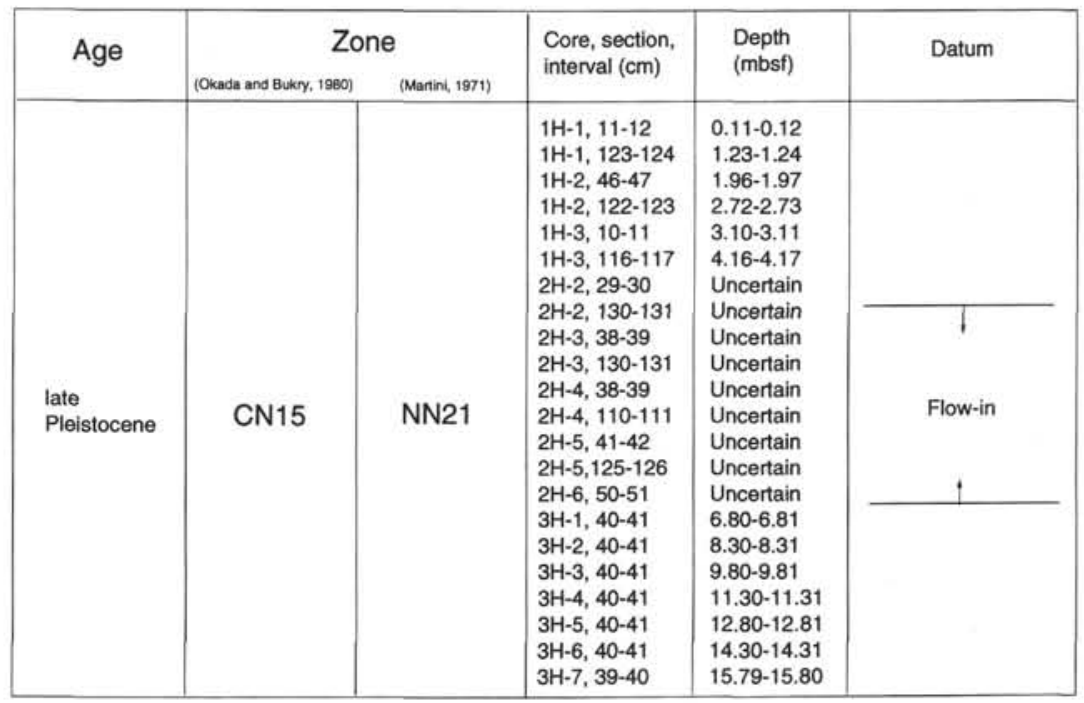

Figure 7. Nannofossil biostratigraphic summary of Hole 831A.

Table 3. Nannofossil range chart for Site 831.

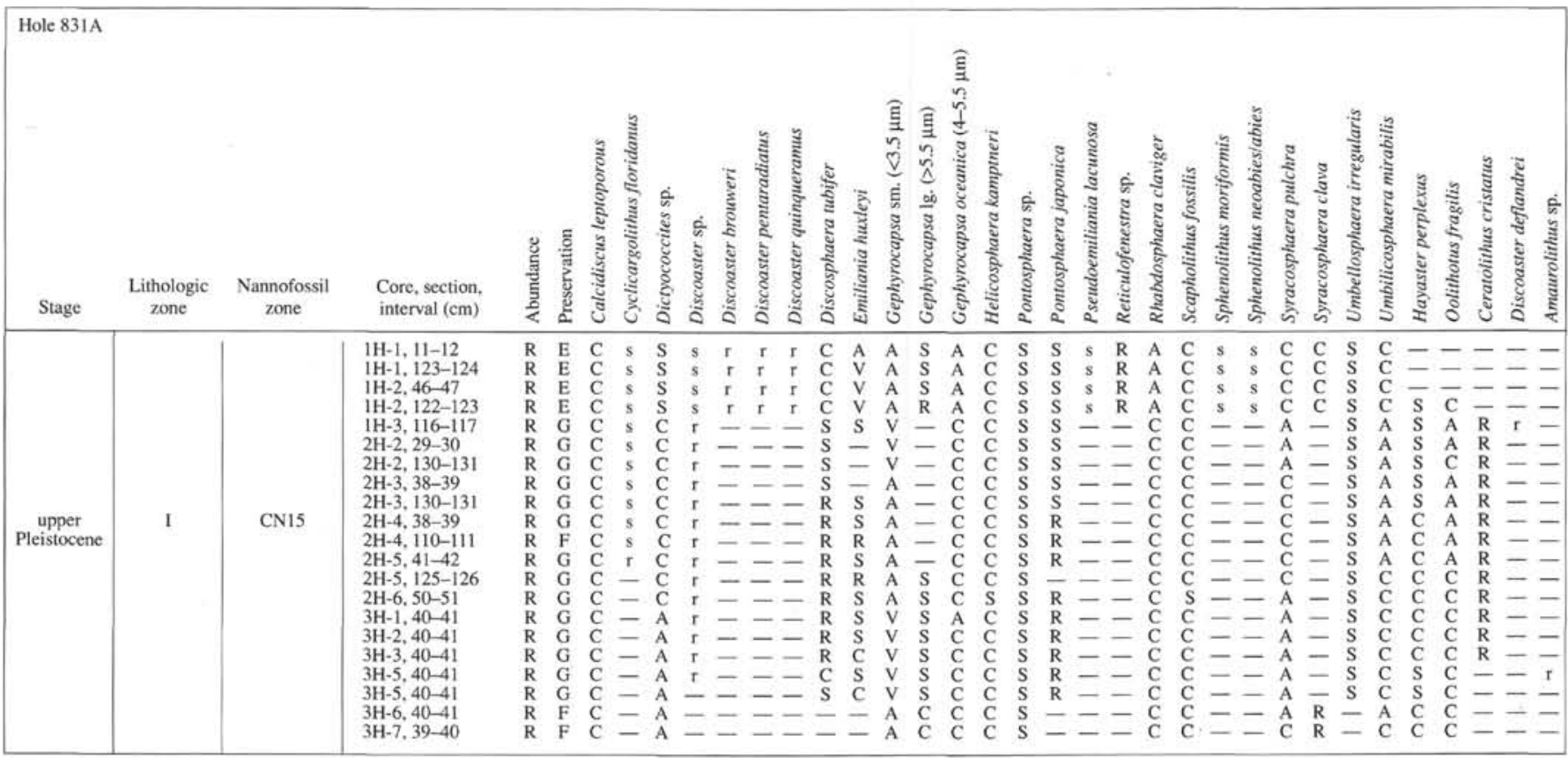

evidence to suggest that the placement of the LAD of $D$. brouweri is correct lies in the increased abundance of the short-ranged $D$. triradiatus in Sample 134-827B-13R-2, 10-11 cm. It is widely accepted that $D$. triradiatus reaches an acme just prior to its extinction, which is coeval with the extinction of $D$. brouweri (Backman and Shackleton, 1983; Rio et al., 1990). Although rare occurrences of D. triradiatus appear upsection, these are interpreted as reworked.

The oldest nannofossil datum interpreted from Site 827 is the LAD of $D$. pentaradiatus. As with LAD of $D$. brouweri, $D$. pentaradiatus is frequently reworked, hindering its utility as a zonal marker. The placement of the LAD of $D$. pentaradiatus in Sample 134-827B$13 \mathrm{R}-4,22-23 \mathrm{~cm}$, is based primarily on an increase in abundance of this species. Lack of reworking in this sample suggests that the abundance increase is not the result of an influx of displaced speci- mens, but rather represents a natural fluctuation. The LAD of $D$. pentaradiatus, therefore, apparently is no lower in the hole than Sample 134-827B-13R-4, 22-23 cm.

\section{Site 829}

Site 829 yielded the most extensive section from the forearc region of the New Hebrides Island Arc with more than $500 \mathrm{~m}$ of nannofossilbearing sediments penetrated in Hole 829A alone. Although recovery was at times exceedingly low, a variety of sediment types and ages was encountered in the cores analyzed aboard ship. Some sediments were noticeably mixed by depositional and/or tectonic processes, whereas others indicated no inherent complexity at all. A variety of clasts and laminae was often encountered within a matrix of a different lithology 
Table 4. Nannofossil range charts for Site 827.

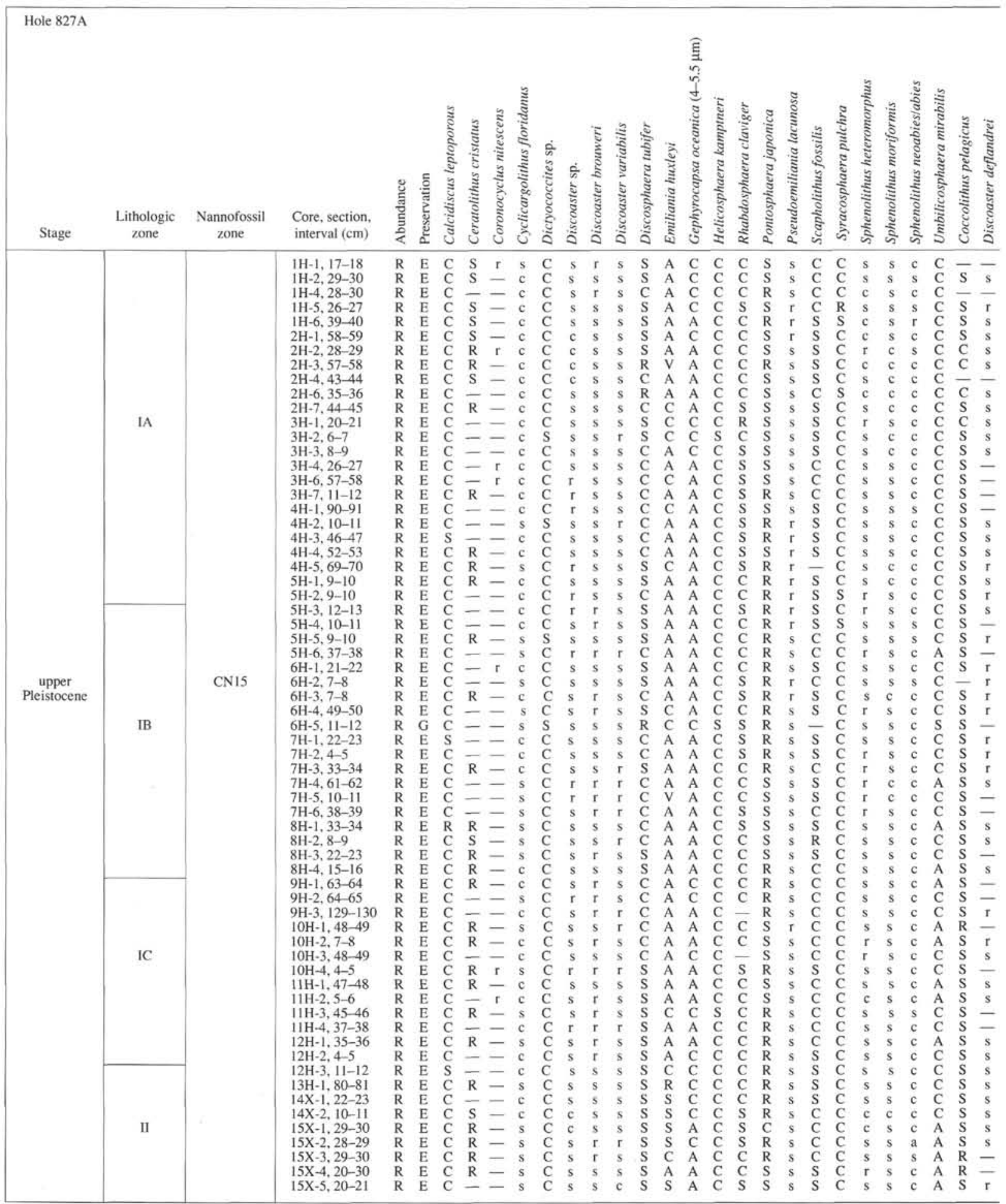

and age. Thick units of uncertain age and origin were also recovered. Shipboard interpretations (Collot, Greene, Stokking, et al., 1992) suggest that two primary depositional facies were found in the accretionary prism: (1) pelagic and hemipelagic sediments originating from the downgoing plate; and (2) material of uncertain origin deposited as a trench fill. The mix of materials of differing sources and possibly different modes of accretion has resulted in a complex arrangement of units of a single age stacked with units containing mixed lithologies and microfossil assemblages.

Aboard ship, the paleontology of the mixed-age olistostromal units, presumed to be trench-fill deposits, was described in less detail than were the units containing sediment of a single age and lithology. Shore-based nannofossil studies have attempted to distinguish and document the various types of clasts and matrices in these previously 
Table 4 (continued).

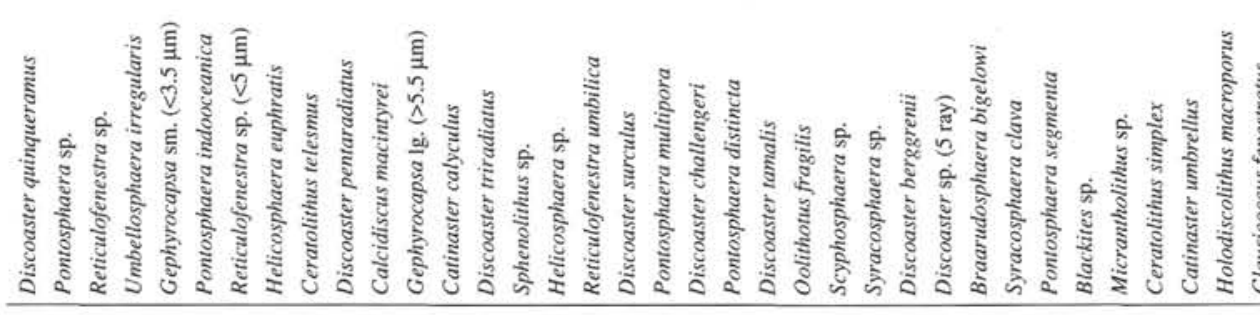

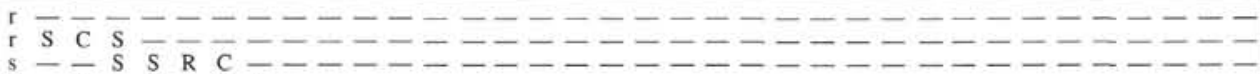

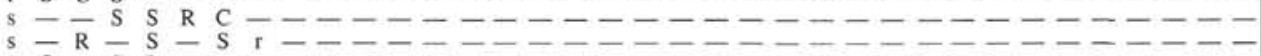

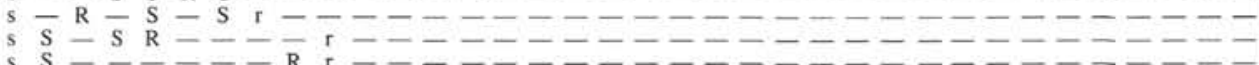

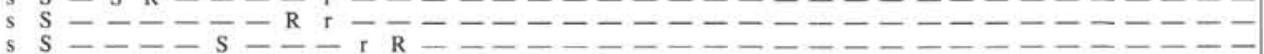

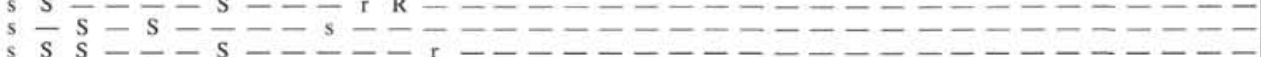

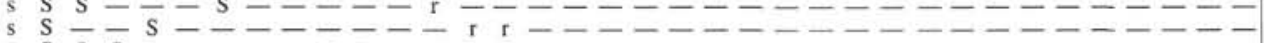

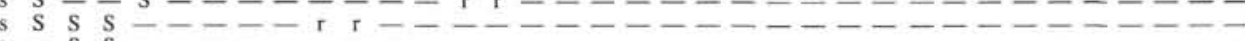

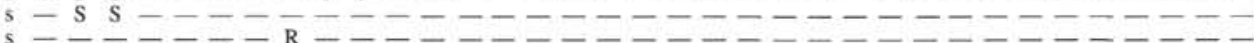

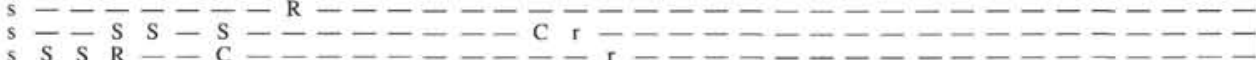

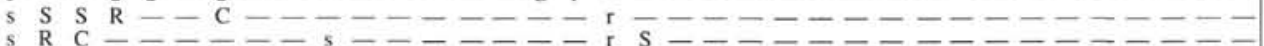

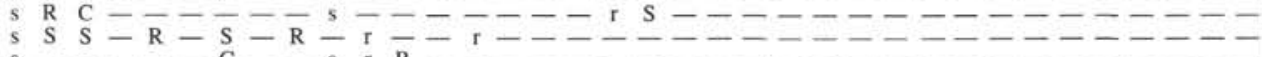

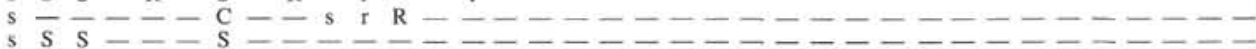

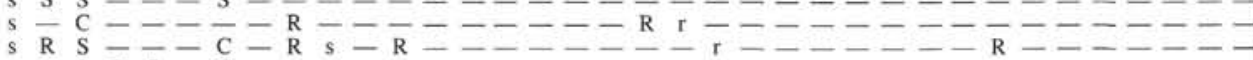

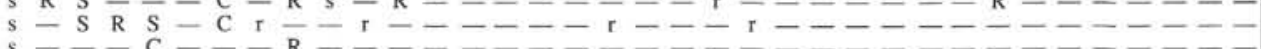

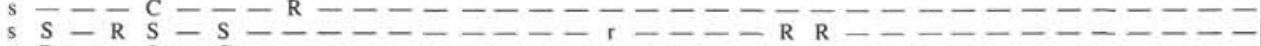

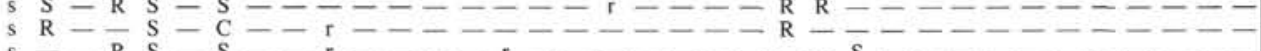

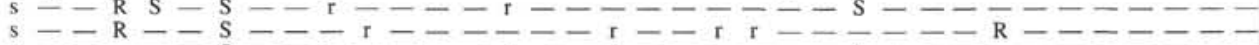

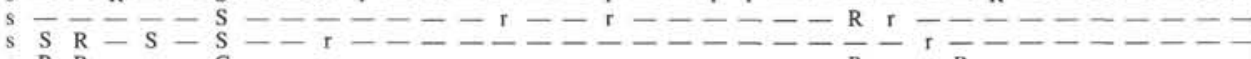

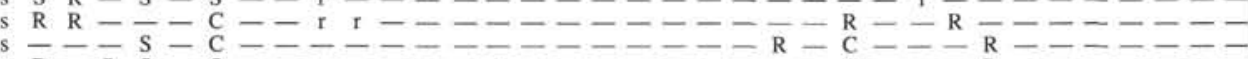

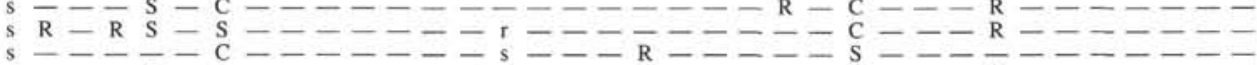

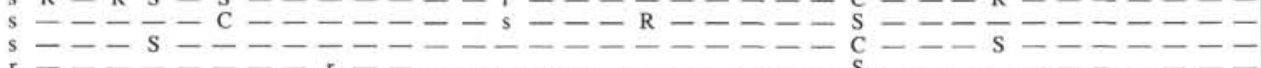

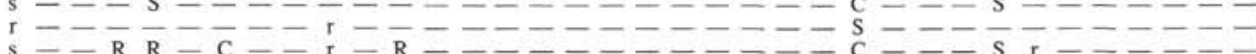

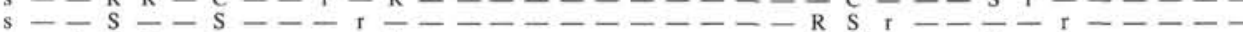

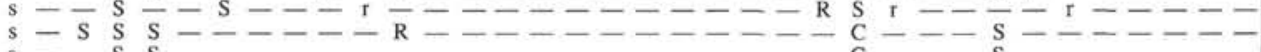

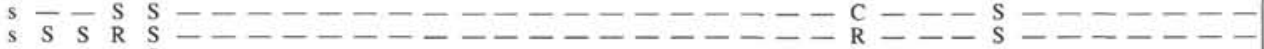

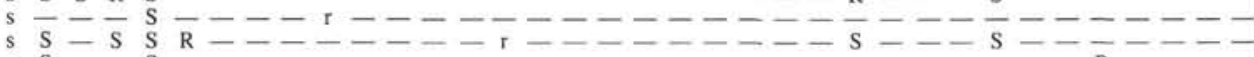

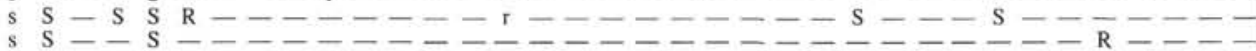

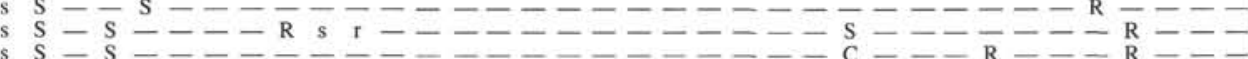

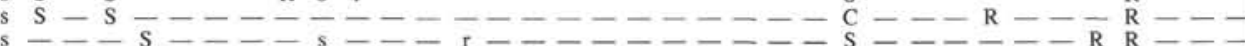

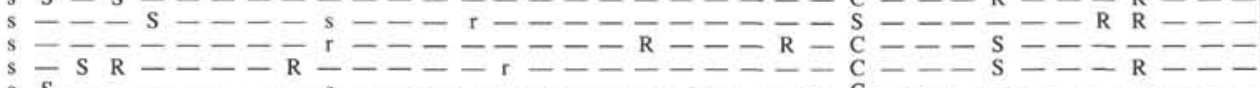

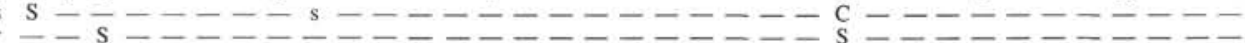

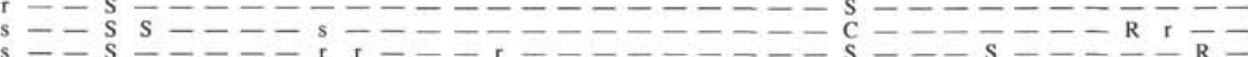

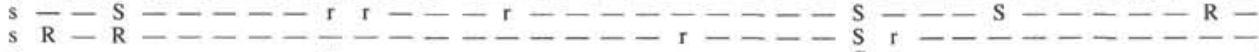

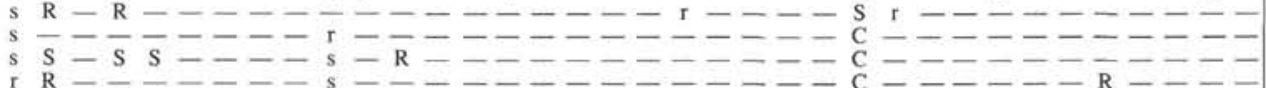

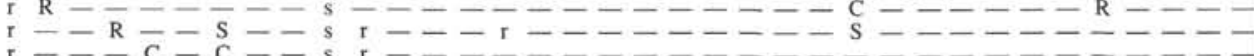

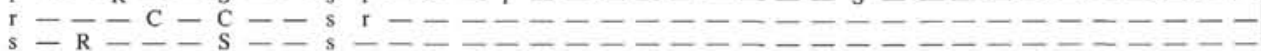

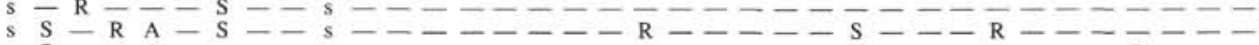

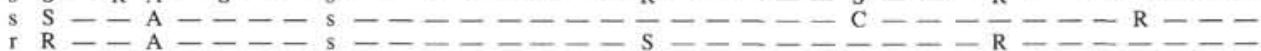

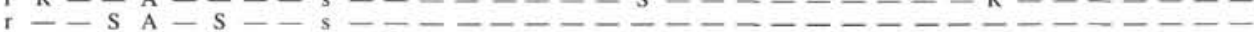

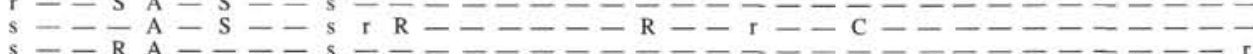

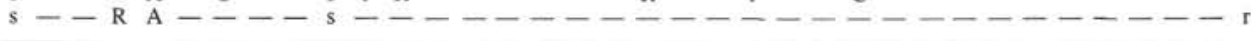

understudied sedimentary breccias. Comparisons of sedimentological, structural, and logging data were combined with biostratigraphy to see if depositional or tectonic mechanisms best explain the complex floral associations in these mixed intervals.

The ensuing discussion concerns only the expanded nannofossil biostratigraphy from the shore-based studies of Site 829 material. Interpretations made from this revised biostratigraphy as to the ori- gins of the sediments and their relationship to the regional geology and depositional setting will be addressed later in this paper.

The revised calcareous nannofossil biostratigraphy indicates the presence of a highly discontinuous stratigraphic record containing sediments ranging in age from the latest Pleistocene Zone CN15 through the late Eocene Zone CP15. Within this range, three discrete ages of sediment consistently recur: Pleistocene siltstones, lower 
Table 4 (continued).

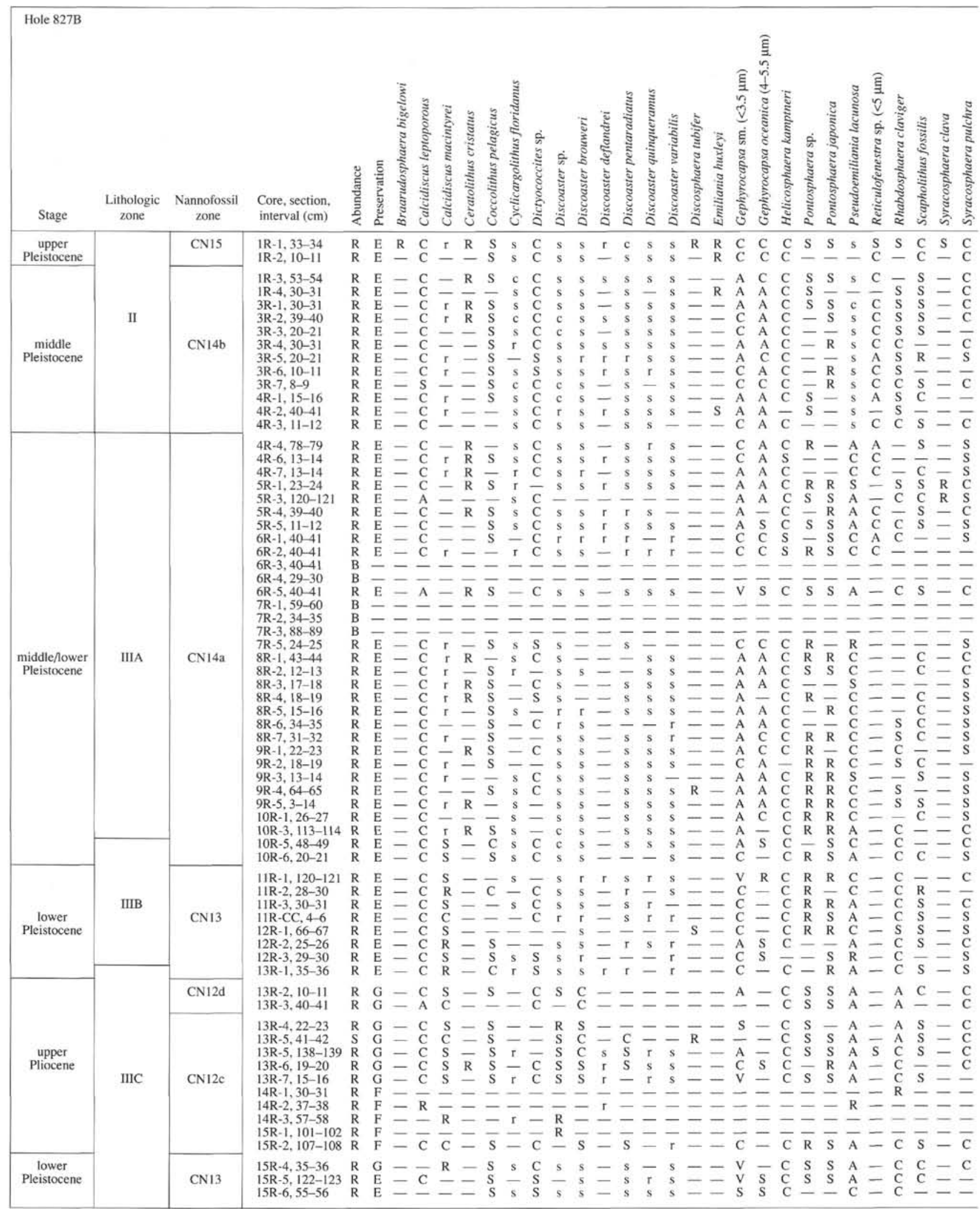




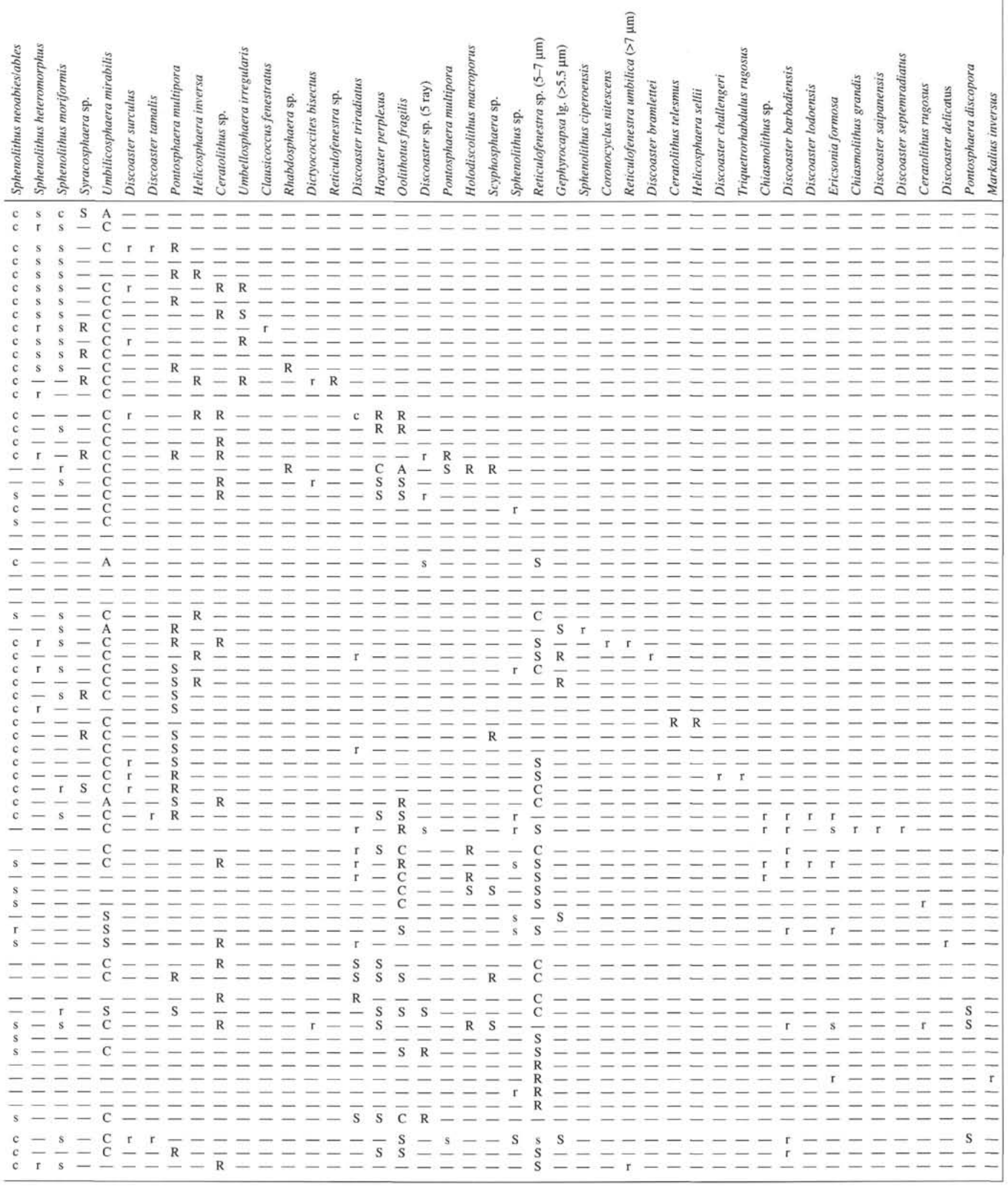


Miocene to lower Oligocene pelagic chalk, and an upper Eocene clayey chalk. Nannofossil assemblages of these three ages are seen both as coherent units within thrust-faulted packages as well as in the mixed sediments and breccias. Less common occurrences of poorly preserved Pliocene and middle Miocene material also occur but have been interpreted to be clasts or olistoliths. Brief descriptions of the nannofossil zones and important taxa observed in Hole 829A are presented below and summarized in Figure 9. Full range charts are presented in Table 5 .

\section{Pleistocene}

Pleistocene siltstones comprise the uppermost cores from Hole $829 \mathrm{~A}$. The interval from Samples 134-829A-1R-1, 35-36 cm, to -6R$2,35-36 \mathrm{~cm}$, contains an assemblage typical of Zone CN15 as indicated by the presence of Emiliania huxleyi, Gephyrocapsa oceanica, small gephyrocapsids, Rhabdosphaera claviger, Helicosphaera kamptneri, Scapholithus fossilis, Calcidiscus leptoporus, Umbilicosphaera mirabilis, Syracosphaera pulchra and rare occurrences of Ceratolithus telesmus. This nannofossil assemblage is repeated again in Samples 134-829A-12R-1, 80-81 cm, through - 13R-1, 70-71 cm, and Samples 134-829A-17R-2, 40-41 cm, through 134-829A-18R-3, 40-41 cm

Samples 134-829A-6R-3, 35-36 cm, through -7R-2, 20-21 cm, belong to the middle to lower Pleistocene Zone CN14 as indicated by an assemblage identical to the superjacent zone except for the absence of E. huxleyi. This floral assemblage is repeated several times in Hole 829A: Samples 134-829A-13R-2, 70-71 cm, through 134-829A-17R1, 40-41 cm, 134-829A-18R-4, 40-41 cm, through -20R-2, 112-113 $\mathrm{cm}, 134-829 \mathrm{~A}-44 \mathrm{R}-1,63-64 \mathrm{~cm}$, through -45R-CC, 134-829A-47R$1,100-101 \mathrm{~cm}$, through $-48 \mathrm{R}-1,14-16 \mathrm{~cm}, 134-829 \mathrm{~A}-48 \mathrm{R}-1,95-96$ $\mathrm{cm}$, and 134-829A-56R-1, 141-142 cm, through -56R-3, 34-35 cm.

\section{Pliocene}

Only six samples were composed entirely of Pliocene age material. Sample $134-829$ A-44R-1, 26-27 cm, is from a 30-cm-thick carbonaterich layer that contains a poorly preserved assemblage of overgrown Discoaster asymmetricus, Discoaster sp. cf. D. brouweri, Discoaster variabilis, C. leptoporus, and Sphenolithus abies/S. neoabies. Samples 134-829A-48R-1, 45-47 cm, and 134-829A-48R-1, 47-48 cm, are from a 4-cm-thick lamina that contains a typical middle Pliocene assemblage of $S$. abies $/ S$. neoabies, $D$. asymmetricus, $D$. brouweri, $D$. challengeri, C. leptoporus, and rare Calcidiscus macintyrei. The poor preservation in these two assemblages makes precise age determinations difficult; however, these samples are unlikely to be younger than $\mathrm{CN} 11$ owing to the presence of $S$. abies/S. neoabies. Pliocene assemblages were also recorded from clasts in Samples 134-829A-56R-1, 145-146 $\mathrm{cm}$, and $-65 \mathrm{R}-2,5-6 \mathrm{~cm}$ (Appendix C); the latter sample also contains sparse occurrences of Reticulofenestra pseudoumbilica and rare Amaurolithus delicatus, which indicates the lower Pliocene Zone CN10.

\section{Miocene}

Although early Miocene nannofossil specimens have been recorded as reworked components throughout Pleistocene sediments, only three samples at Site 829 are considered unequivocally Miocene in age, and all appear to be clasts. Sediments indicative of the lower Miocene Zone CN4 are recorded from Samples 134-829C-19R-5, 104-105 cm, 134-829A-20R-1, 135-136 cm, and -20R-2, 62-63 cm (Appendix C). The typical assemblage from these samples includes Cyclicargolithus floridanus, Discoaster deflandrei, Cyclicargolithus abisectus, and the marker species Sphenolithus heteromorphus.

\section{Miocene/Oligocene}

The nannofossil biostratigraphy for several intervals is problematic because of the poor preservation: Samples 134-829A-8R-CC,
6-7 cm, through -11R-CC, 8-9 cm, 134-829A-23R-1, 46-47 cm, $-23 \mathrm{R}-1,46-47 \mathrm{~cm}$, through $-23 \mathrm{R}-2,19-20 \mathrm{~cm}, 134-829 \mathrm{~A}-34 \mathrm{R}-1$, $80-81 \mathrm{~cm}$, through $-37 \mathrm{R}-1,35-36 \mathrm{~cm} ;-47 \mathrm{R}-1,27-29 \mathrm{~cm},-49 \mathrm{R}-\mathrm{CC}$, 21-22 cm, $-49 \mathrm{R}-\mathrm{CC}$, and $-54 \mathrm{R}-1,5-6 \mathrm{~cm}$. The typical assemblage from these intervals contains $C$. abisectus, $C$. floridanus, Sphenolithus dissimilis and severely overgrown discoasters believed to be $D$. deflandrei. The lack of age-diagnostic markers in this interval prevents precise zonal determinations; however, the assemblage is representative of the early Miocene/late Oligocene boundary and is, therefore, tentatively placed in a combined Zone CN1/CP19.

\section{Oligocene}

From Samples 134-829A-40R-1, 60-61 cm, through -43R-1, $15-16 \mathrm{~cm}$, the presence of $S$. distentus, $S$. predistentus, $C$. abisectus, $C$. floridanus, and $D$. deflandrei indicates a zonal designation of either Zone CP18 or CP17 both of which are late to early Oligocene in age (see Appendix A discussion). This assemblage is repeated in Samples 134-829A-50R-1, 33-35 cm, -54R-1, 30-31 cm, through $-54 \mathrm{R}-\mathrm{CC}$ and $-55 \mathrm{R}-1,104-105 \mathrm{~cm}$, through $-55 \mathrm{R}-\mathrm{CC}, 10-12 \mathrm{~cm}$.

A lower Oligocene assemblage typified by Ericsonia formosa, Reticulofenestra umbilica, C. floridanus, D. bisectus, Claussicoccus fenestrata, D. deflandrei, and Dictycoccites scrippsae is recorded in Samples 134-829A-55R-1, 42-44 cm, through 134-829A-55R-1, 99$100 \mathrm{~cm}$. These samples are assigned the lower Oligocene Zone CP16. The interval from Samples 134-829A-43R-1, 72-73 cm, through 134$829 \mathrm{~A}-43 \mathrm{R}-1,105-106 \mathrm{~cm}$, is problematic because the assemblage is characteristic of the lowermost Oligocene Zone CP16 with the exception of one specimen of the Eocene marker Discoaster barbadiensis. This one specimen would normally be regarded as reworked except that adjacent samples both above and below are clearly of Eocene age.

\section{Eocene}

Upper Eocene samples are found in sediments from the following intervals in Hole 829A: Samples 134-829A-43R-1, 44-45 cm, -43R-2, $40-41 \mathrm{~cm},-47 \mathrm{R}-1,57-58 \mathrm{~cm}$, through $-47 \mathrm{R}-1,58-59 \mathrm{~cm}$, and $-51 \mathrm{R}-1$, $14-15 \mathrm{~cm}$, through $-51 \mathrm{R}-2,97-98 \mathrm{~cm}$. The typical assemblage contains much the same species as the next youngest zone of Oligocene age, but the presence of Discoaster saipanensis and D. barbadiensis dictates a zonal designation of CP15 for these samples.

\section{Mixed-age Sediments and Breccias}

As with the holes discussed previously, reworking is a minor problem throughout the siltstone sediments interpreted to be Pleistocene in age. Because these sediments are both lithologically and paleontologically distinct, however, the Pleistocene is easily distinguished from the older pelagic chalk deposits found interspersed within the forearc. A problem arises where slumping, tectonization, or a combination of both processes has combined materials of different ages to produce a mix of clasts and in-situ matrix rock. Detailed sampling of the mixed lithologies was undertaken to separate the various components.

Aboard ship, sedimentological studies of the cores from Hole $829 \mathrm{~A}$ identified one zone in which numerous clasts of differing lithologies are within a light- to dark-gray siltstone matrix and a second interval in which chalk clasts reside in a chalk matrix (Collot, Greene, Stokking, et al., 1992; Reid et al., this volume). The first of these mixed zones is a siltstone-chalk breccia in Sections 134-829A-19R-4 to $-23 \mathrm{R}-1$. There are predominately two ages of clasts in this interval. From Sections 134-829A-19R-4 through -20R-2, chalk clasts containing a well-preserved middle Miocene ( $\mathrm{CN} 4)$ assemblage typified by abundant $S$. heteromorphus are found together with siltstone clasts dated as Pleistocene Zone CN14 (Appendix C; Reid et al., this volume). An interclast material, referred to as sandy matrix (Collot, 
A

\begin{tabular}{|c|c|c|c|c|c|}
\hline Age & (Bukry) & (Martini) & $\begin{array}{l}\text { Core, Section, } \\
\text { interval }(\mathrm{cm})\end{array}$ & $\begin{array}{l}\text { Depth } \\
\text { (mbsf) }\end{array}$ & Datum \\
\hline \multirow{2}{*}{$\begin{array}{l}\text { late } \\
\text { Pleistocene }\end{array}$} & \multirow[b]{2}{*}{ CN15 } & \multirow[b]{2}{*}{ NN 21} & $\begin{array}{l}1 \mathrm{H}-1,17-18 \\
1 \mathrm{H}-2,29-30 \\
1 \mathrm{H}-4,28-29 \\
1 \mathrm{H}-5,26-27 \\
1 \mathrm{H}-6,39-40 \\
2 \mathrm{H}-1,58-59 \\
2 \mathrm{H}-2,28-29 \\
2 \mathrm{H}-3,57-58 \\
\end{array}$ & \begin{tabular}{|l}
$0.17-0.18$ \\
$1.79-1.80$ \\
$4.78-4.79$ \\
$6.26-6.27$ \\
$7.89-7.90$ \\
$10.38-10.39$ \\
$11.58-11.59$ \\
$13.37-13.38$ \\
\end{tabular} & \multirow{2}{*}{$\begin{array}{c}\downarrow \\
70.17 \mathrm{~m} \\
\downarrow\end{array}$} \\
\hline & & & $\begin{array}{l}12 \mathrm{H}-1,35-36 \\
12 \mathrm{H}-2,4-5 \\
12 \mathrm{H}-3,11-12 \\
13 \mathrm{H}-1,80-81 \\
14 \mathrm{X}-1,22-23 \\
14 \mathrm{X}-2,10-11 \\
15 \mathrm{X}-1,29-30 \\
15 \mathrm{X}-2,28-29 \\
15 \mathrm{X}-3,29-30 \\
15 \mathrm{X}-4,20-21 \\
15 \mathrm{X}-5,20-21\end{array}$ & \begin{tabular}{|l|}
$83.55-83.56$ \\
$85.10-85.11$ \\
$86.31-86.32$ \\
$88.60-88.61$ \\
$91.72-91.73$ \\
$93.10-93.11$ \\
$101.29-101.30$ \\
$102.78-102.79$ \\
$104.29-104.30$ \\
$105.70-105.71$ \\
$107.20-107.21$ \\
\end{tabular} & \\
\hline
\end{tabular}

B

\begin{tabular}{|c|c|c|c|c|c|}
\hline \multirow[t]{2}{*}{ Age } & \multicolumn{2}{|c|}{ Zone } & \multirow{2}{*}{$\begin{array}{l}\text { Core, section, } \\
\text { interval }(\mathrm{cm})\end{array}$} & \multirow[t]{2}{*}{$\begin{array}{l}\text { Depth } \\
\text { (mbsf) }\end{array}$} & \multirow[t]{2}{*}{ Datum } \\
\hline & (Okada and Bukry, 1980) & (Martini, 1971) & & & \\
\hline $\begin{array}{l}\text { late } \\
\text { Pleistocene }\end{array}$ & CN15 & NN 21 & $\begin{array}{l}1 \mathrm{R}-1,33-34 \\
1 \mathrm{R}-2,10-11\end{array}$ & $\begin{array}{l}110.93-110.94 \\
112.20-112.21\end{array}$ & FAD E. huxleyi \\
\hline \multirow{3}{*}{$\begin{array}{l}\text { middle } \\
\text { Pleistocene }\end{array}$} & CN14b & NN20 & $\begin{array}{l}1 R-3,53-54 \\
1 R-4,30-31 \\
3 R-1,30-31 \\
3 R-2,39-40 \\
3 R-3,20-21 \\
3 R-4,30-31 \\
3 R-5,20-21 \\
3 R-6,10-11 \\
3 R-7,8-9 \\
4 R-1,15-16 \\
4 R-2,40-41 \\
4 R-3,11-12\end{array}$ & $\begin{array}{l}114.13-114.14 \\
115.40-115.41 \\
127.50-127.51 \\
129.09-129.10 \\
130.40-130.41 \\
132.00-132.01 \\
133.40-133.41 \\
134.80-134.81 \\
136.28-136.29 \\
137.05-137.06 \\
138.80-138.81 \\
140.01-140.02\end{array}$ & $\begin{array}{l}\text { LAD P. lacunosa } \\
0.46 \mathrm{Ma}\end{array}$ \\
\hline & & \multirow{4}{*}{ NN19 } & $\begin{array}{l}4 R-4,78-79 \\
4 R-5,114-115 \\
4 R-6,13-14 \\
4 R-7,13-14 \\
5 R-1,23-24 \\
5 R-2,09-10 \\
5 R-3,12-13 \\
\end{array}$ & \begin{tabular}{r|}
$142.18-142.19$ \\
$144.04-144.05$ \\
$144.53-144.54$ \\
$146.03-146.04$ \\
$146.73-146.74$ \\
$148.09-148.10$ \\
$149.62-149.63$ \\
\end{tabular} & $\uparrow_{70.17 \mathrm{~m}}$ \\
\hline & $\mathrm{CN} 14 \mathrm{a}$ & & $\begin{array}{l}9 R-5,13-14 \\
10 R-1,26-27 \\
10 R-2,15-16 \\
10 R-3,113-114 \\
10 R-4,43-44\end{array}$ & $\begin{array}{l}191.23-191.24 \\
194.96-194.97 \\
196.35-196.36 \\
198.83-198.84 \\
199.63-199.64\end{array}$ & $\begin{array}{l}\downarrow \\
\text { LAD C. macintyrei }\end{array}$ \\
\hline $\begin{array}{l}--\ldots-1 \\
\text { early } \\
\text { Pleistocene }\end{array}$ & & & $\begin{array}{l}10 \mathrm{R}-4,119-120 \\
10 \mathrm{R}-5,48-49 \\
10 \mathrm{R}-6,20-21 \\
11 \mathrm{R}-1,74-75 \\
11 \mathrm{R}-2,28-29 \\
11 \mathrm{R}-3,30-31\end{array}$ & $\begin{array}{l}200.39-200.40 \\
201.18-201.19 \\
202.40-202.41 \\
205.14-205.15 \\
206.18-206.19 \\
207.70-207.71\end{array}$ & $\begin{array}{l}\text { FAD G. oceanica } \\
1.58 \mathrm{Ma}\end{array}$ \\
\hline \multirow[t]{3}{*}{----} & CN13 & & $\begin{array}{l}12 R-1,66-67 \\
12 R-2,25-26 \\
12 R-3,29-30 \\
13 R-1,35-36\end{array}$ & $\begin{array}{l}214.66-214.67 \\
215.75-215.76 \\
217.29-217.30 \\
224.05-224.06\end{array}$ & $\begin{array}{l}\text { LAD D. brouweri } \\
\text { (D. triradiatus) }\end{array}$ \\
\hline & CN12d & NN18 & $\begin{array}{l}13 R-2,10-11 \\
13 R-3,40-41\end{array}$ & $\begin{array}{l}225.30-225.31 \\
227.10-227.11\end{array}$ & LAD D. pentaradiatus \\
\hline & CN12c? & NN17? & $\begin{array}{l}13 R-4,22-23 \\
13 R-5,41-42 \\
13 R-6,19-20 \\
13 R-7,15-16 \\
14 R-1,30-31 \\
14 R-2,37-38 \\
14 R-3,57-58 \\
15 R-1,101-102 \\
15 R-2,107-108\end{array}$ & $\begin{array}{l}228.42-228.43 \\
230.11-230.12 \\
231.39-231.40 \\
232.85-232.86 \\
233.60-233.61 \\
235.17-235.18 \\
236.87-236.88 \\
244.01-244.02 \\
245.57-245.58\end{array}$ & $\begin{array}{l}\text { - Barren } \\
\text { - Barren } \\
\text { - Barren } \\
\text { - Barren }\end{array}$ \\
\hline $\begin{array}{l}\text { early } \\
\text { Pleistocene }\end{array}$ & $\mathrm{CN} 14 \mathrm{a}$ & NN19 & $\begin{array}{l}15 R-4,35-36 \\
15 R-5,122-123 \\
15 R-6,55-56\end{array}$ & $\begin{array}{l}247.85-247.86 \\
250.22-250.23 \\
251.05-251.06\end{array}$ & $\begin{array}{r}\text { Reocurrence } \\
\text { G. oceanica }\end{array}$ \\
\hline
\end{tabular}

Figure 8. Nannofossil biostratigraphic summary. A. Hole 827A. B. Hole 827B. 
Table 5. Nannofossil range charts for Site 829.

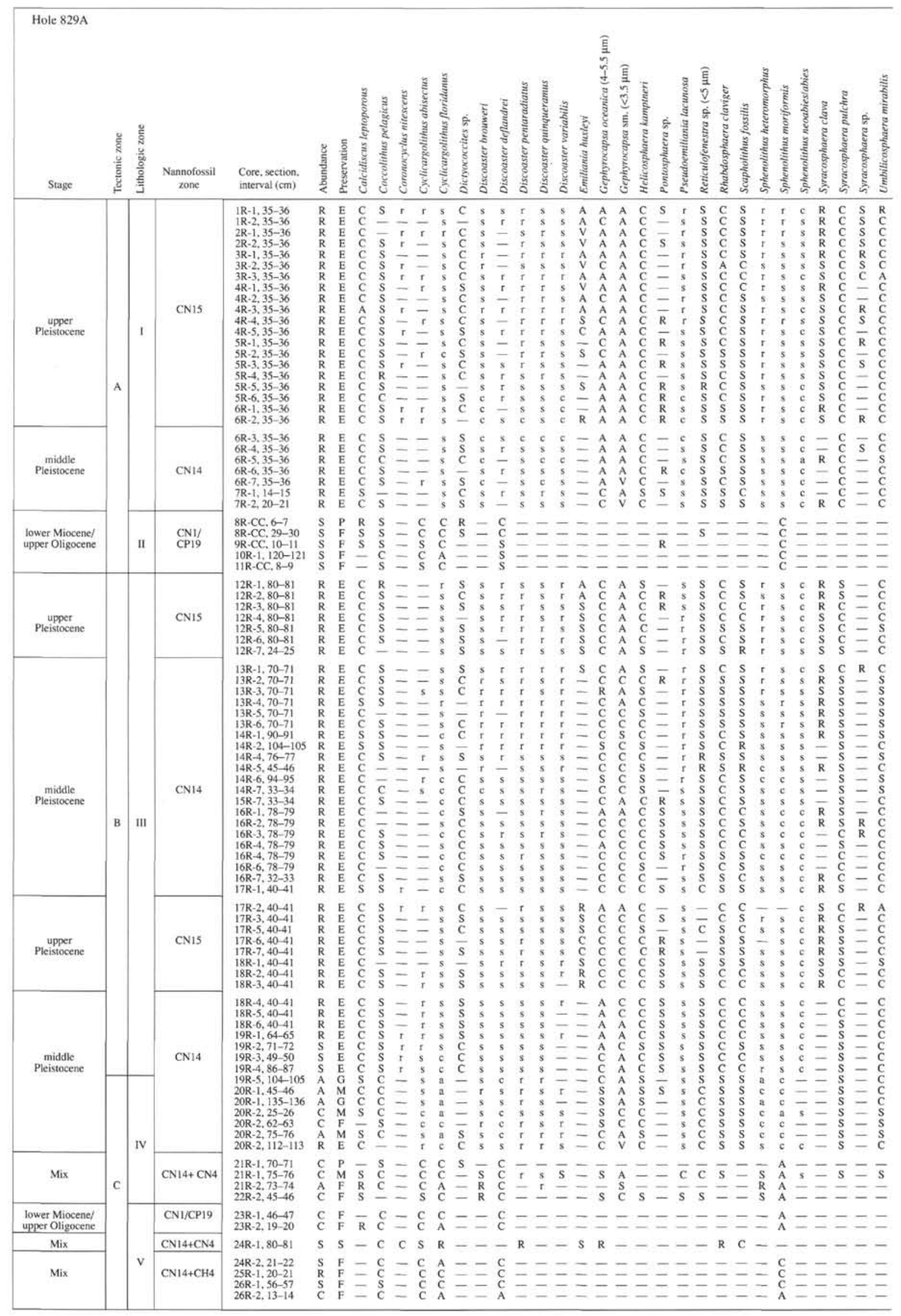




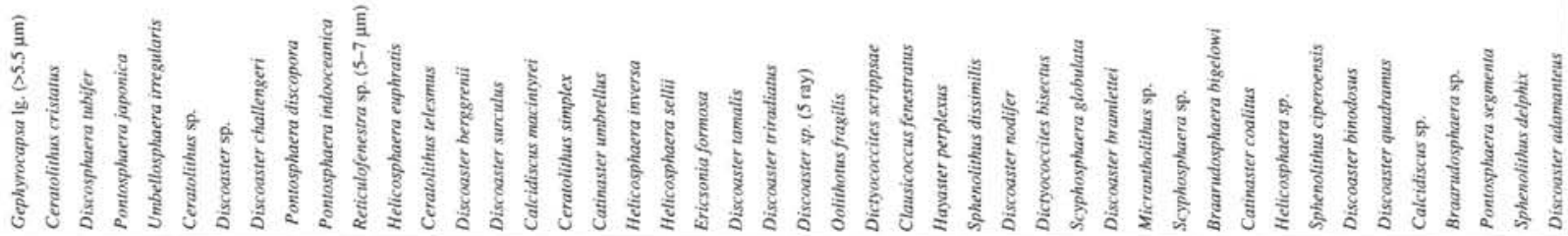

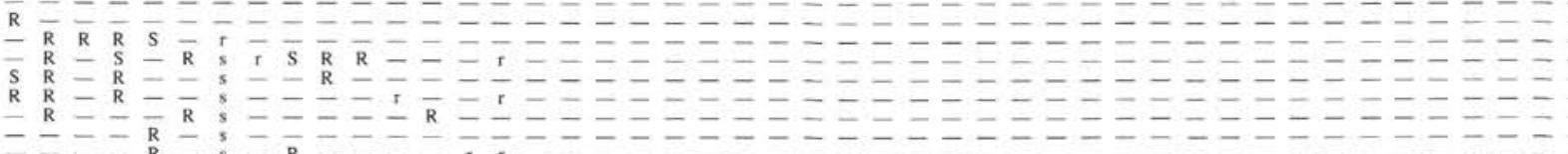

$\bar{R}=\bar{R}=\bar{R}$
$\bar{R} \bar{S}=\bar{R}=\bar{R}$
$-R=\bar{R}$
$R$

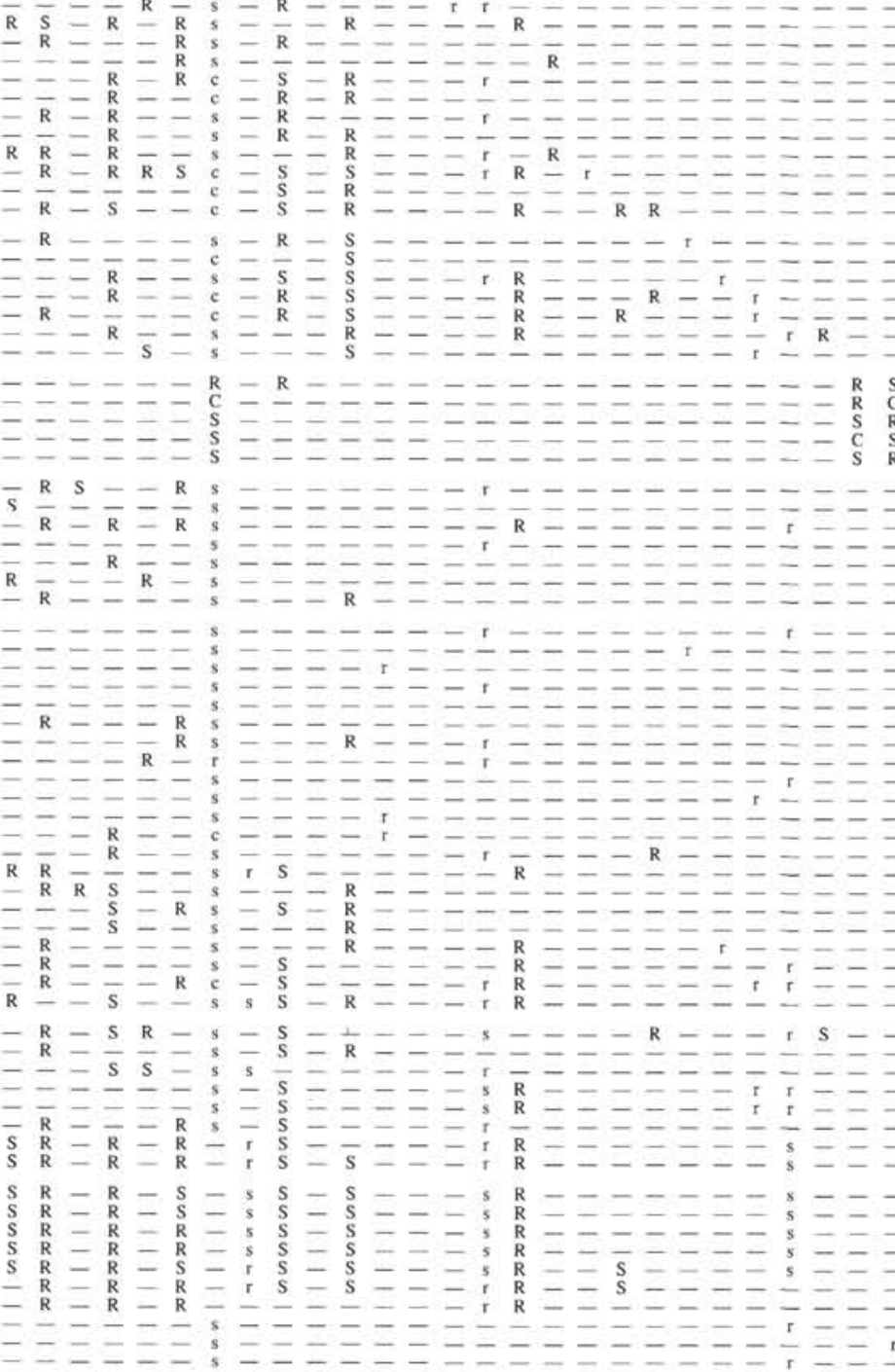

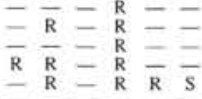

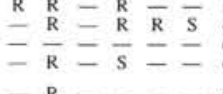

$\bar{Z}=\bar{R}=\bar{Z}$
$\bar{Z}=\mathrm{R}$
$\overline{\mathrm{R}}=\mathrm{R}$

$=\frac{R}{-}=\frac{R}{R} \bar{s}=$

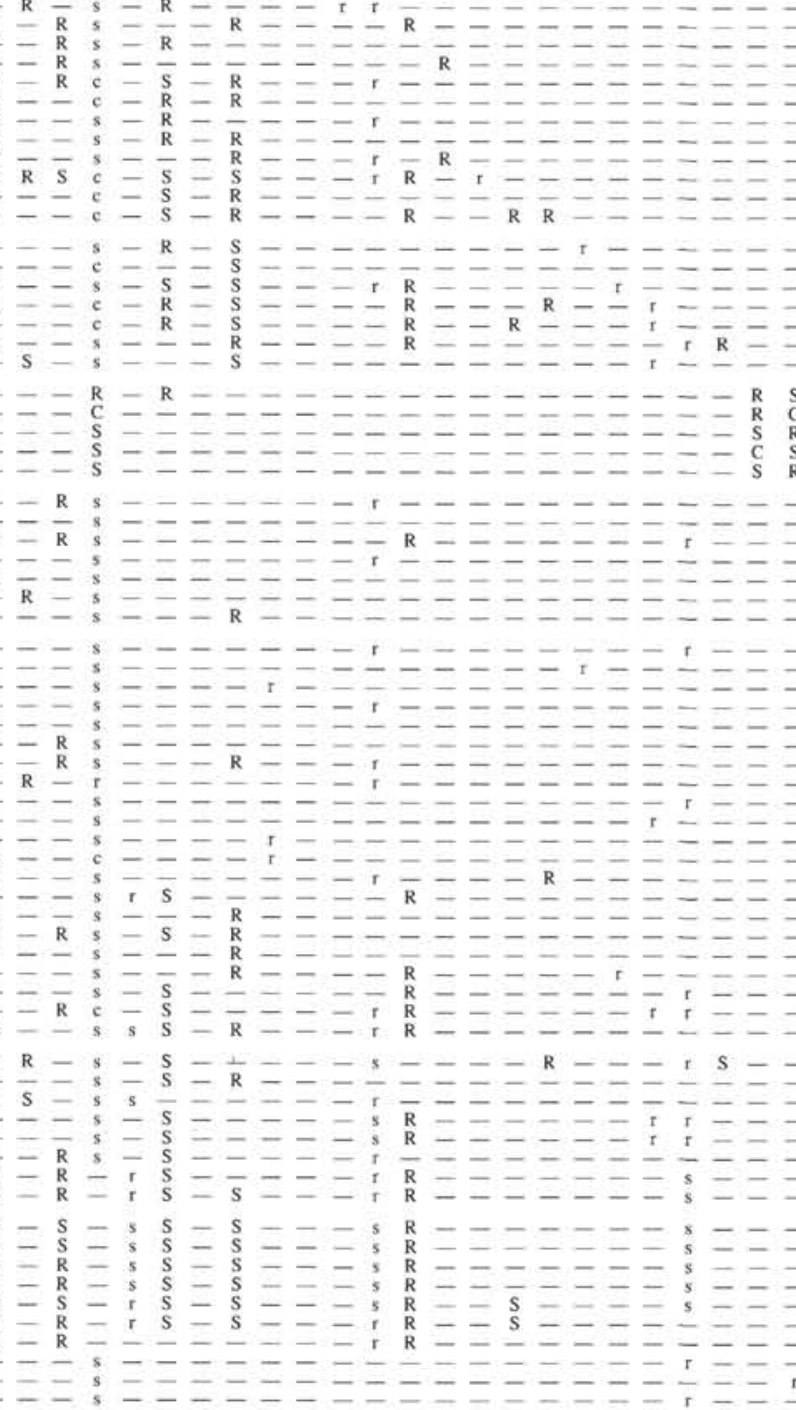

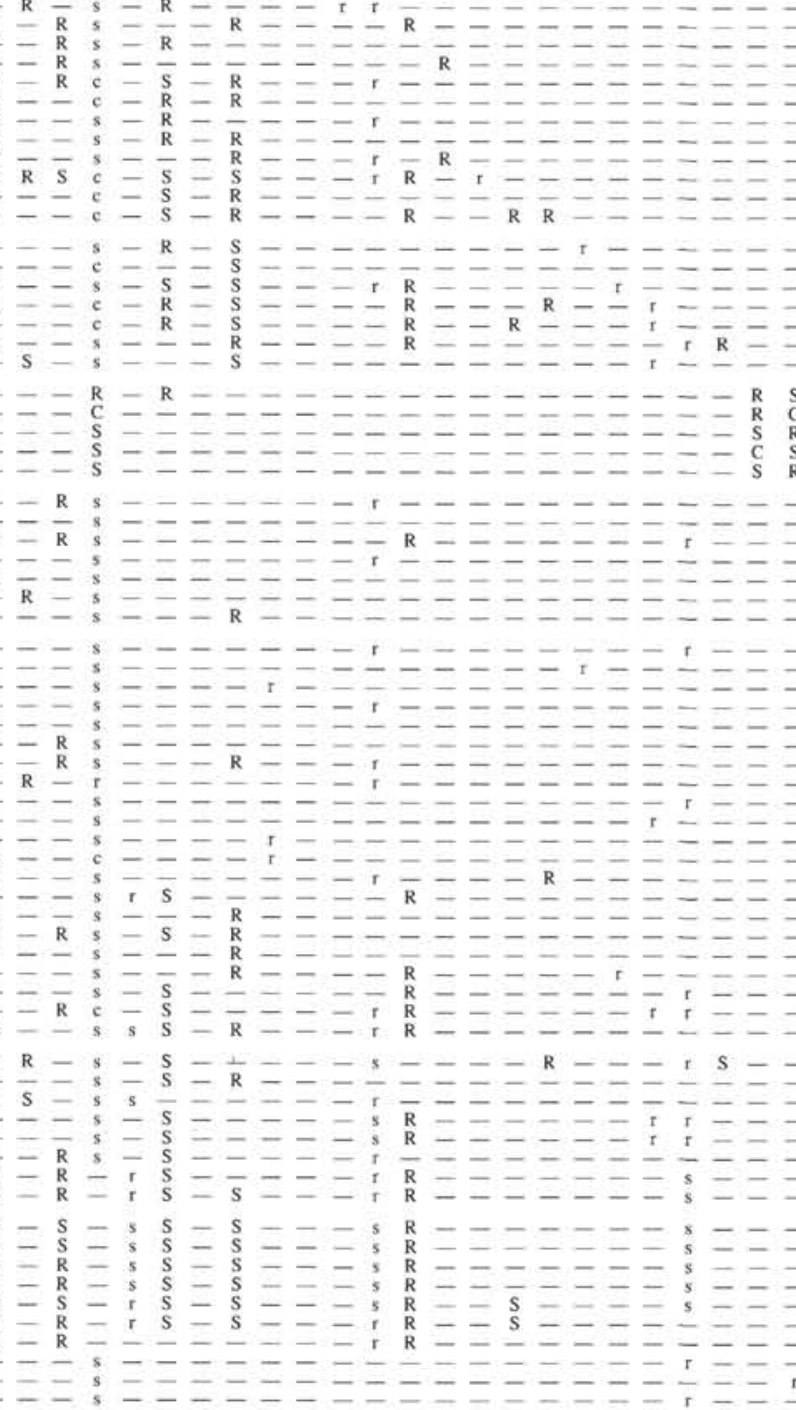

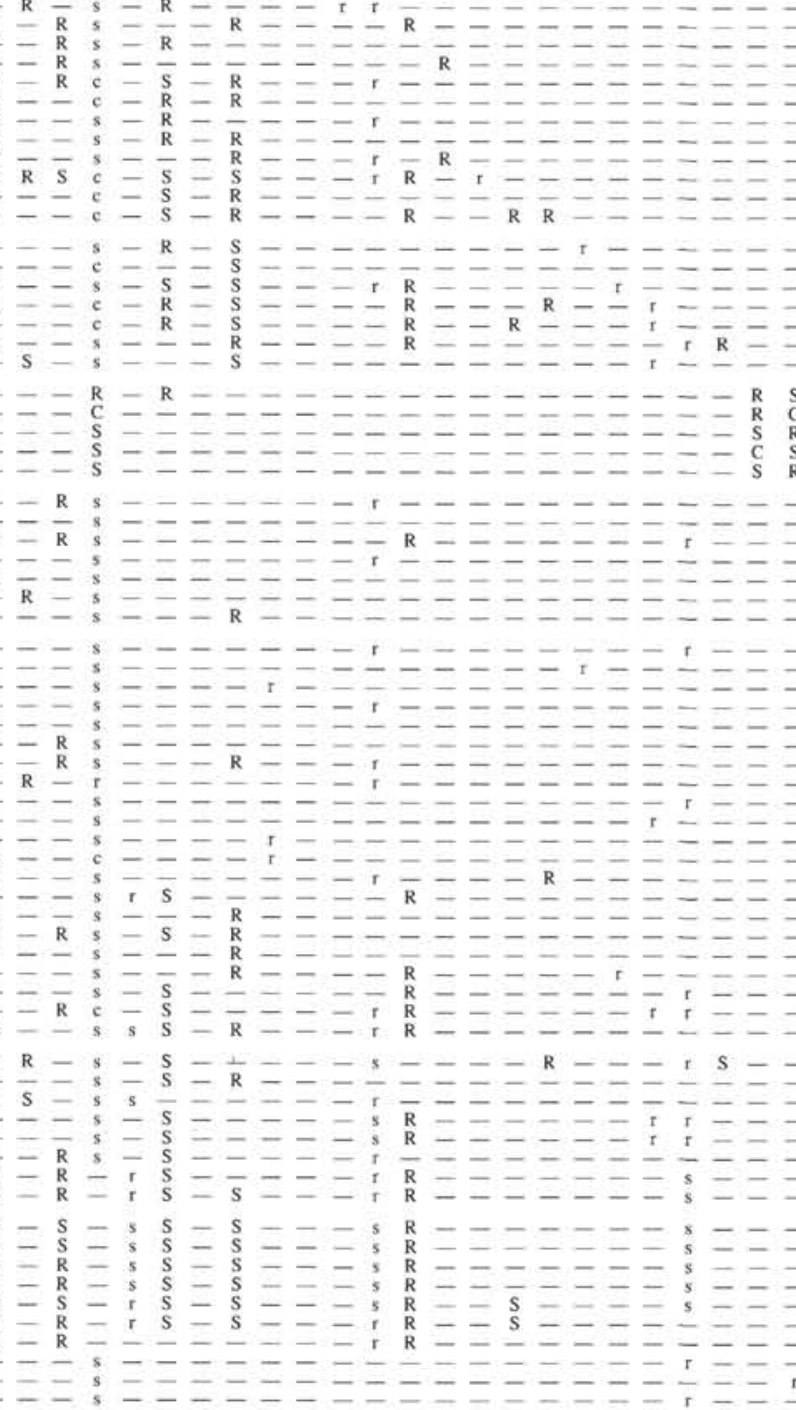

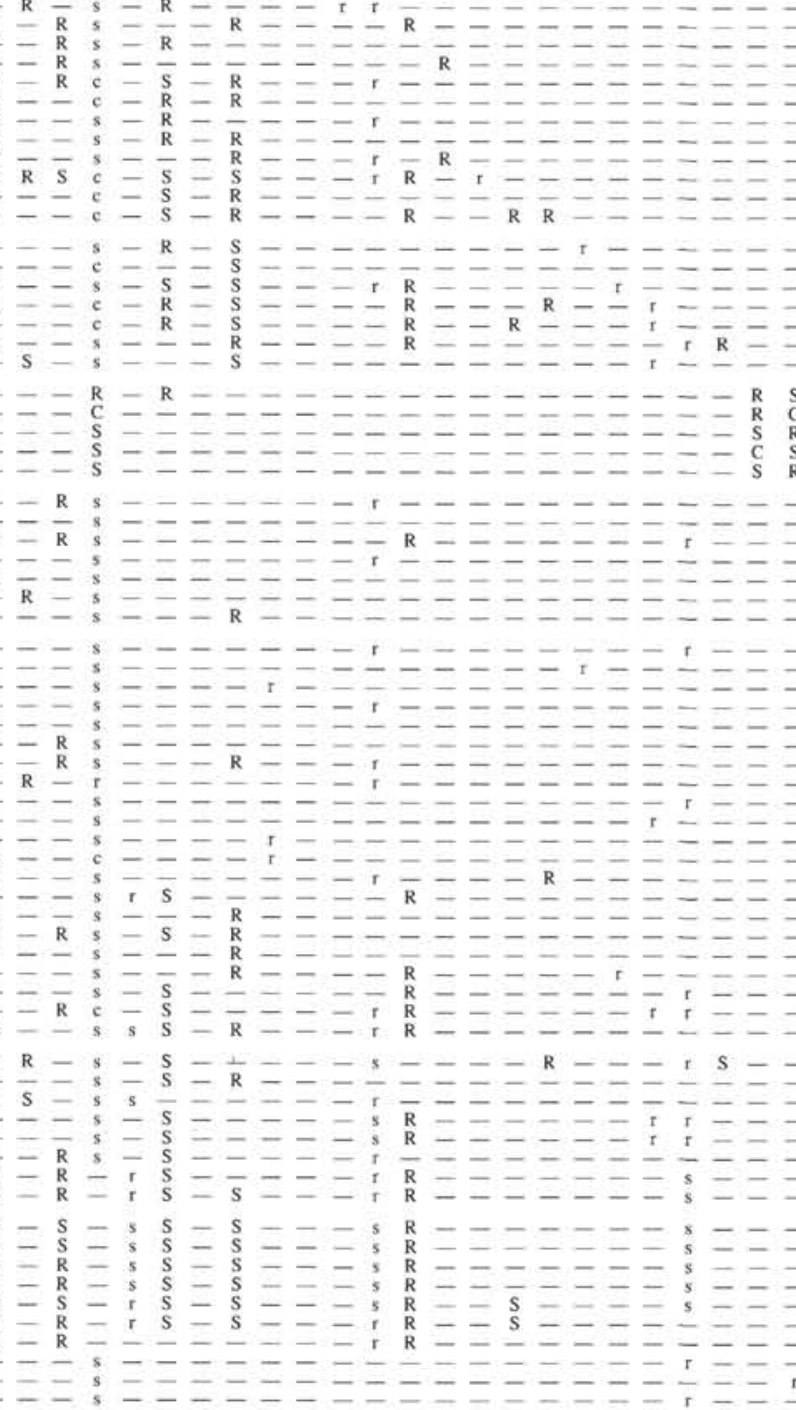

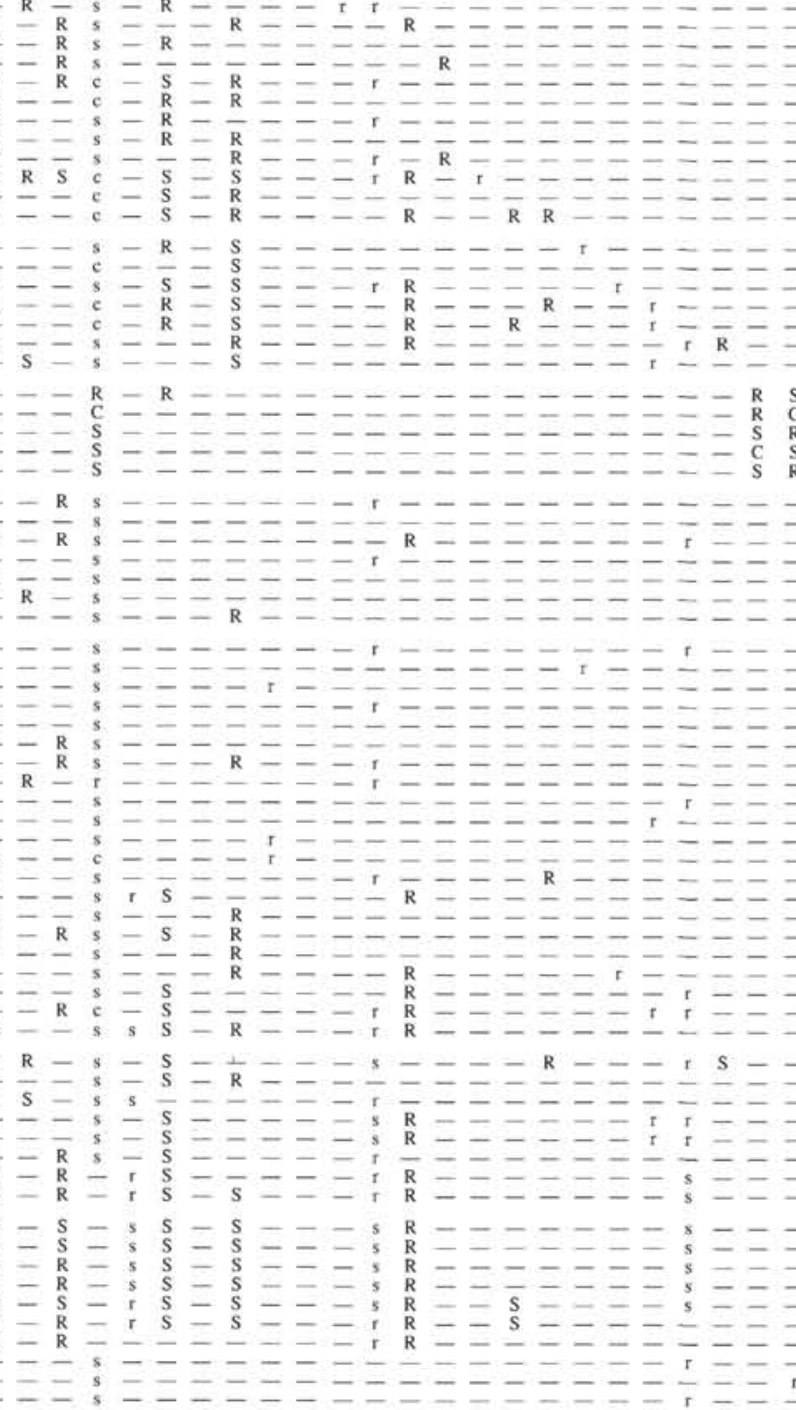

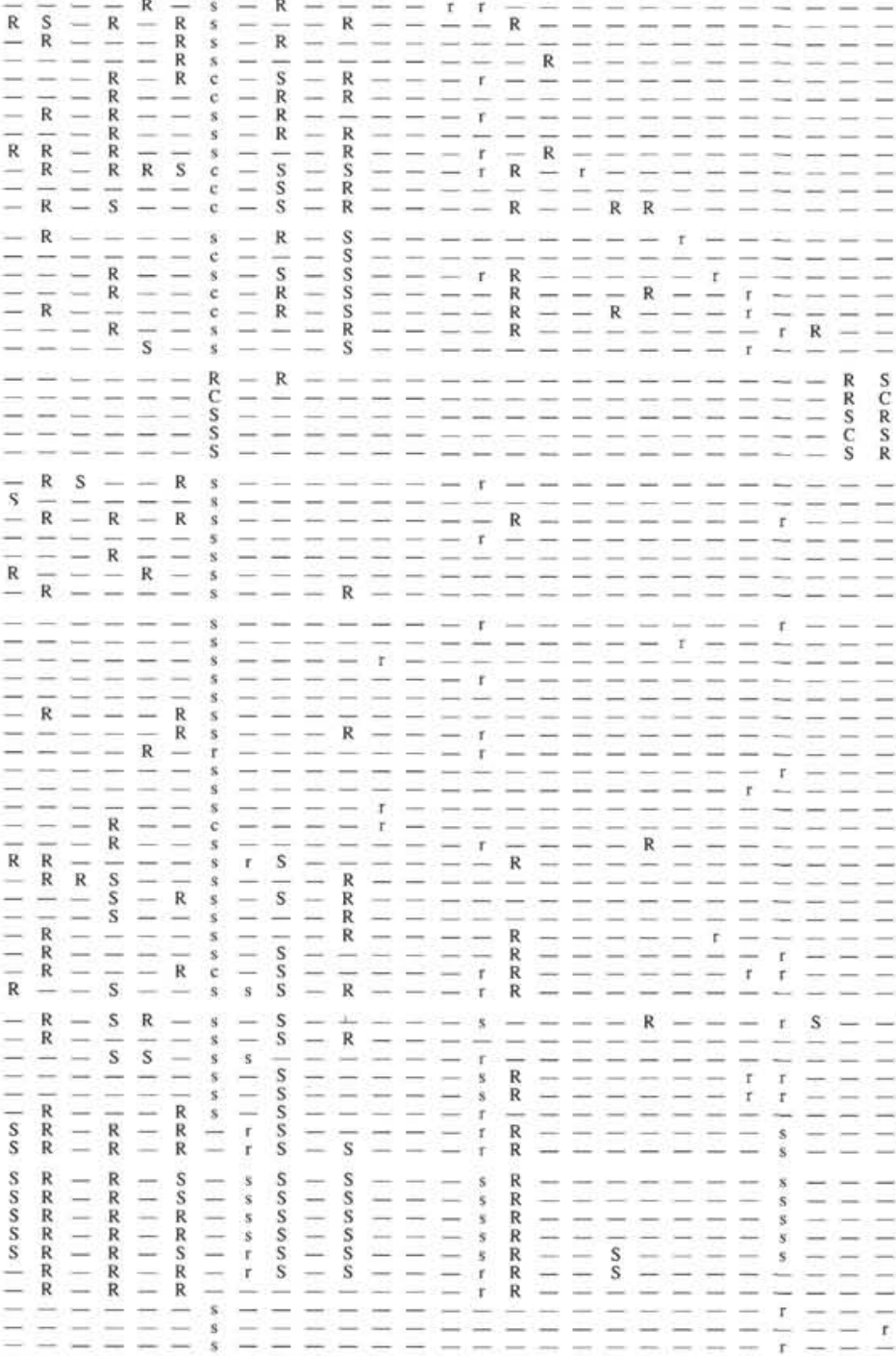

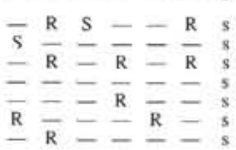

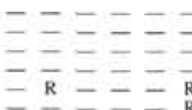

$\bar{Z}= \pm \bar{R}$ R

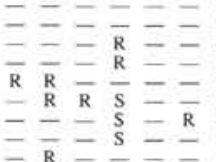

$\bar{Z}=\bar{R}=\bar{Z}$
$\bar{R}=\bar{R}=\bar{R}$
$\bar{R}=\bar{S}=\underline{R}$

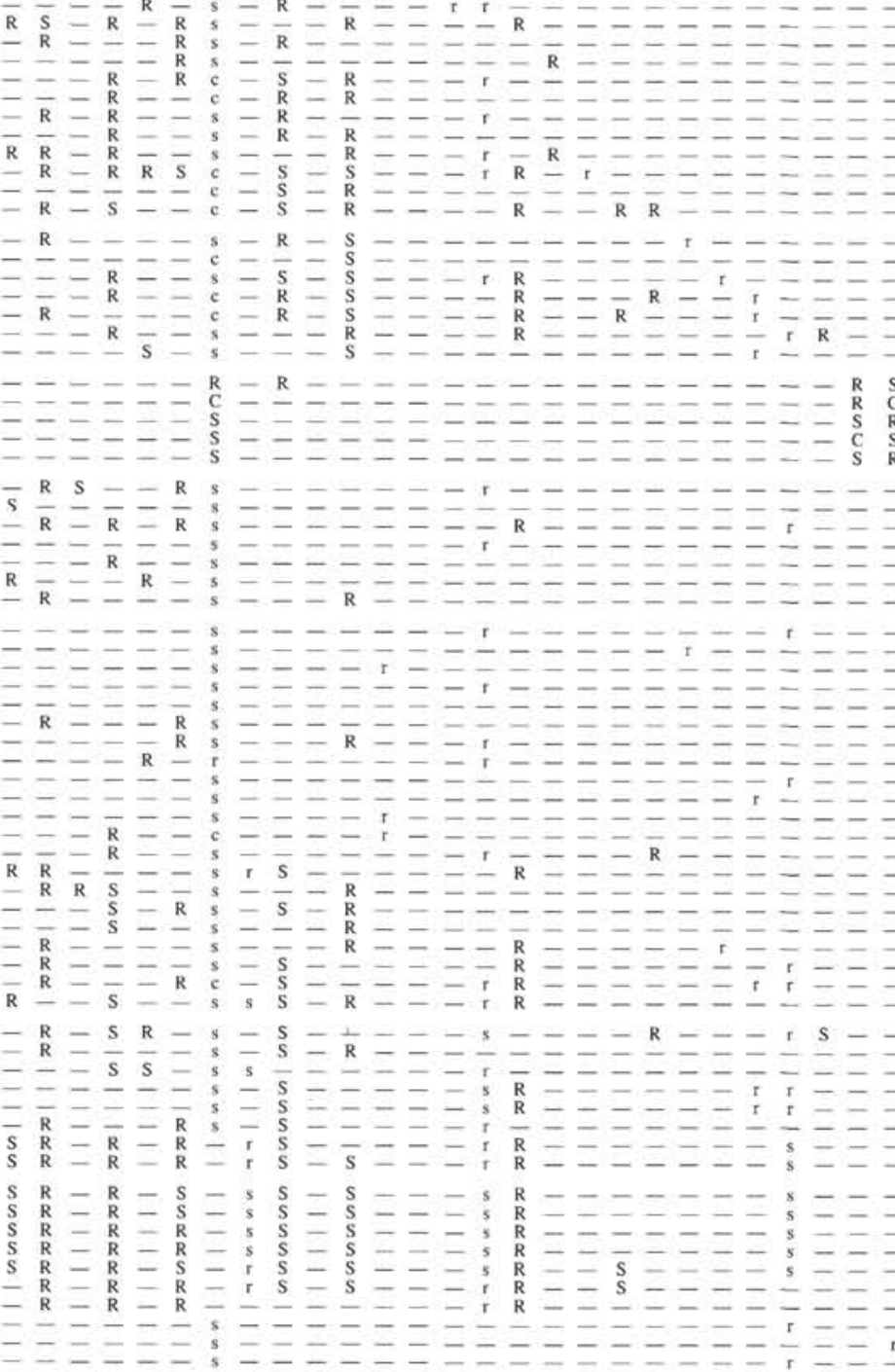

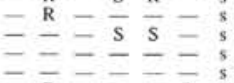

$\bar{R}=\bar{T}=\bar{R}$
$\bar{S} R_{R}=\bar{R}=R$
$S R$
$R$

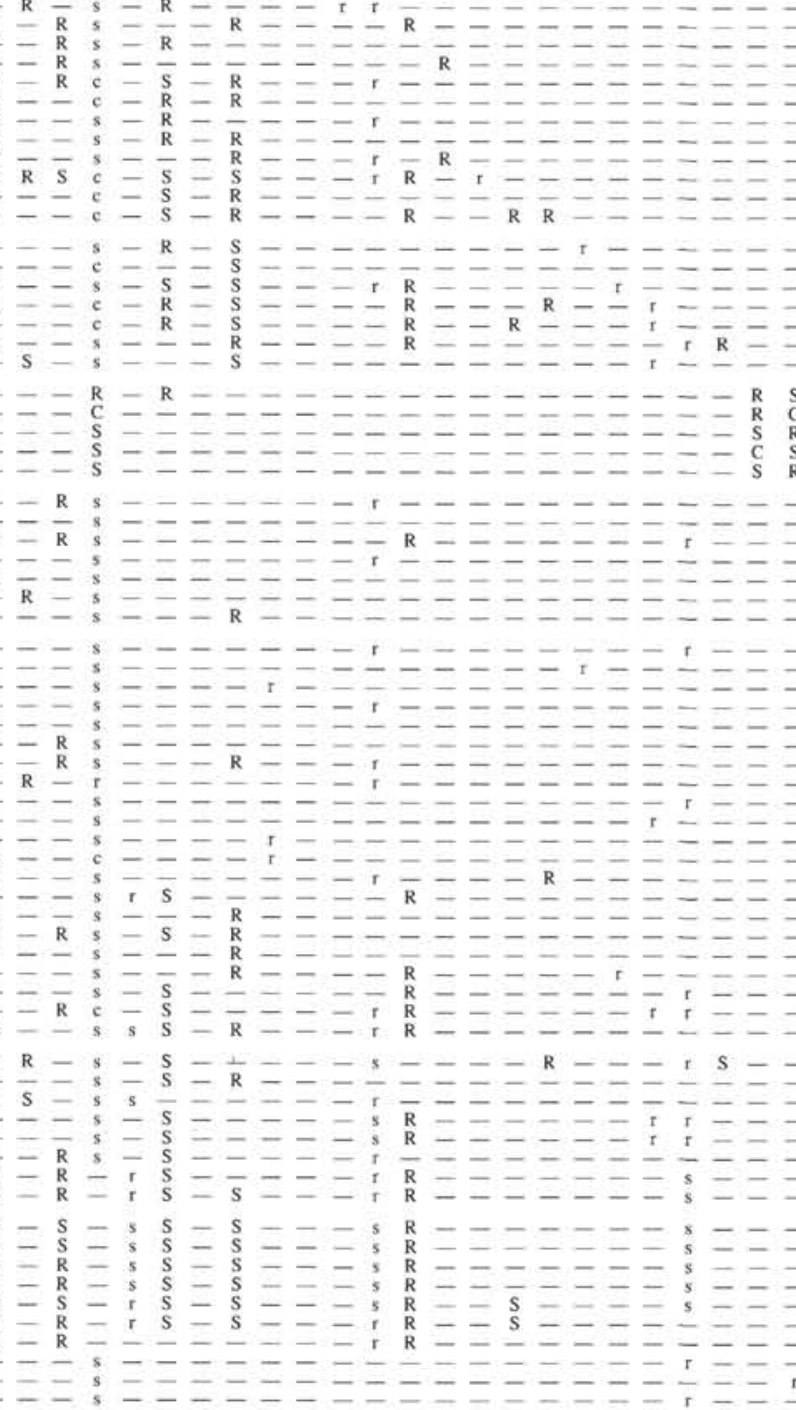

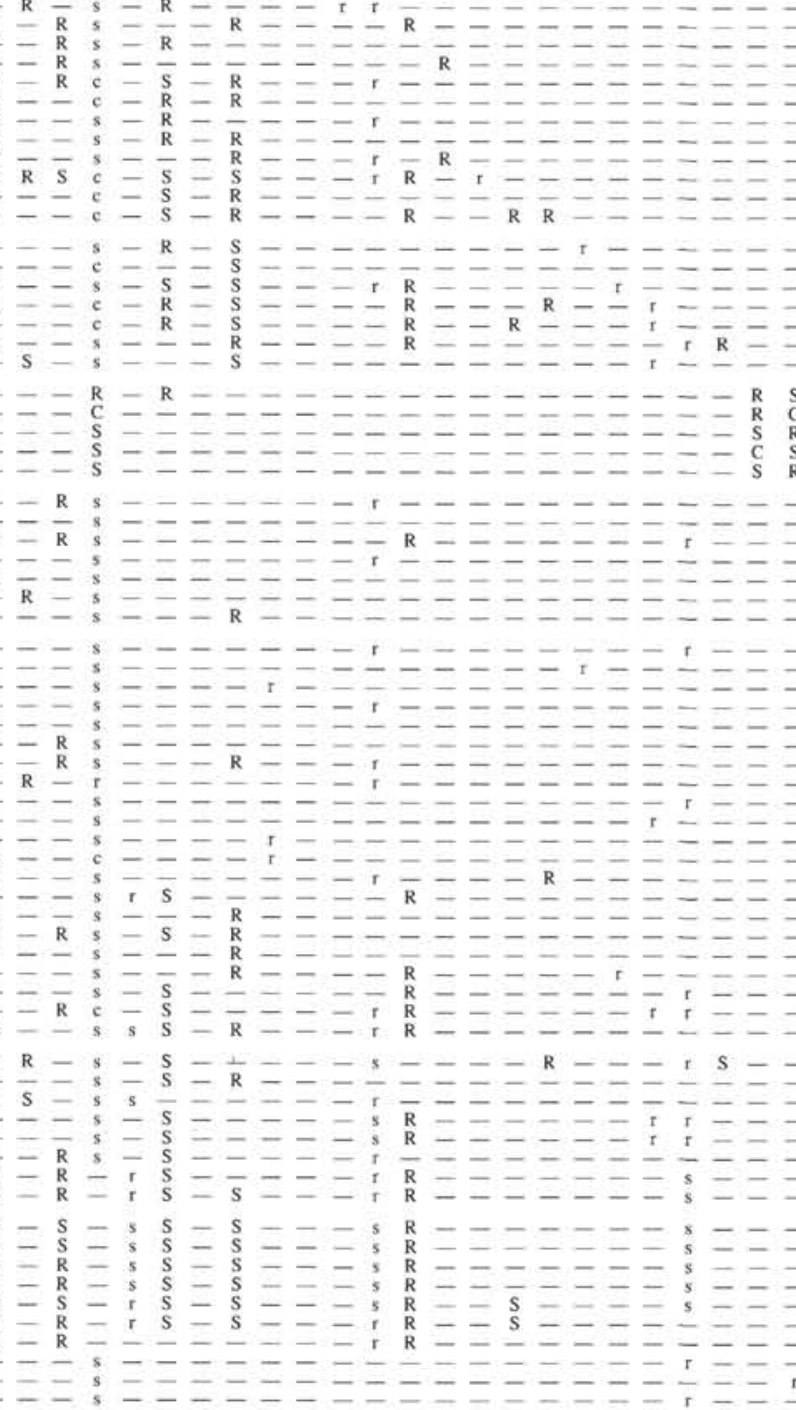

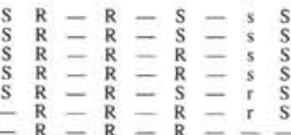

$=R=R=R$

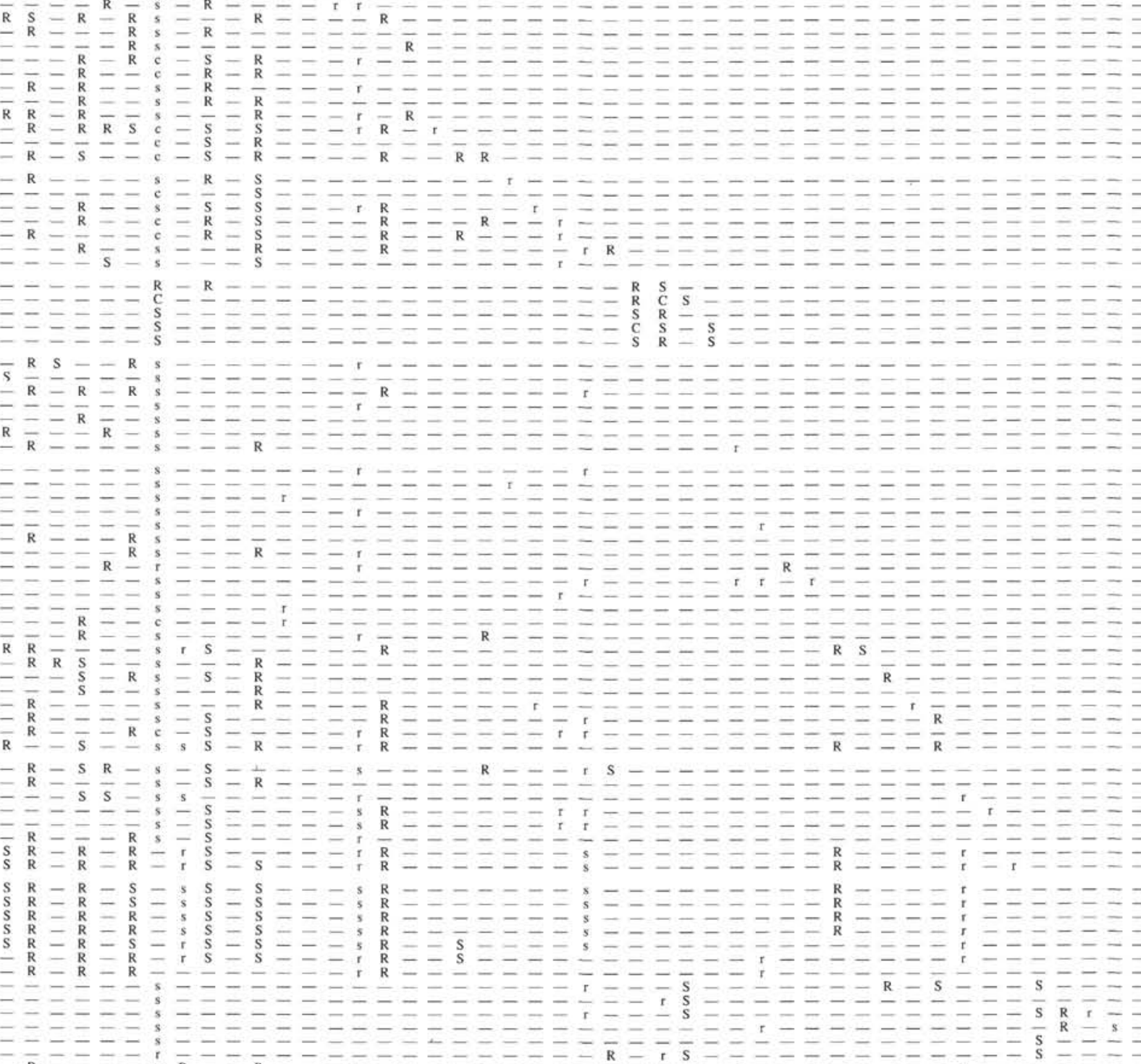

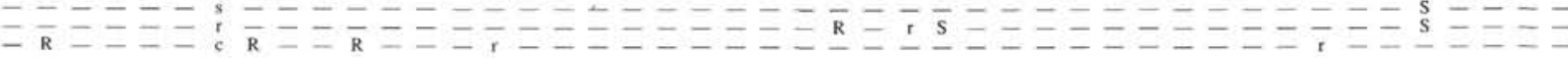

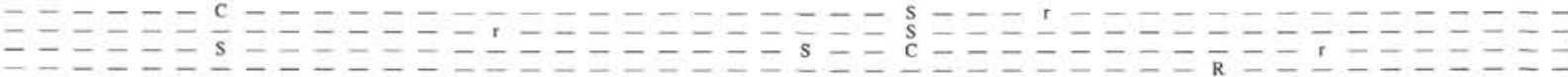
Iニニニニニ

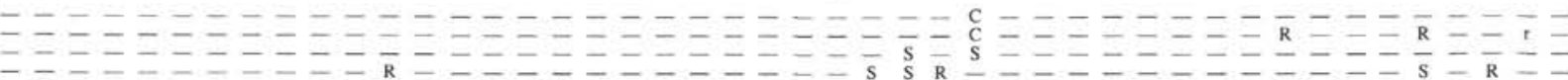


Table 5 (continued).

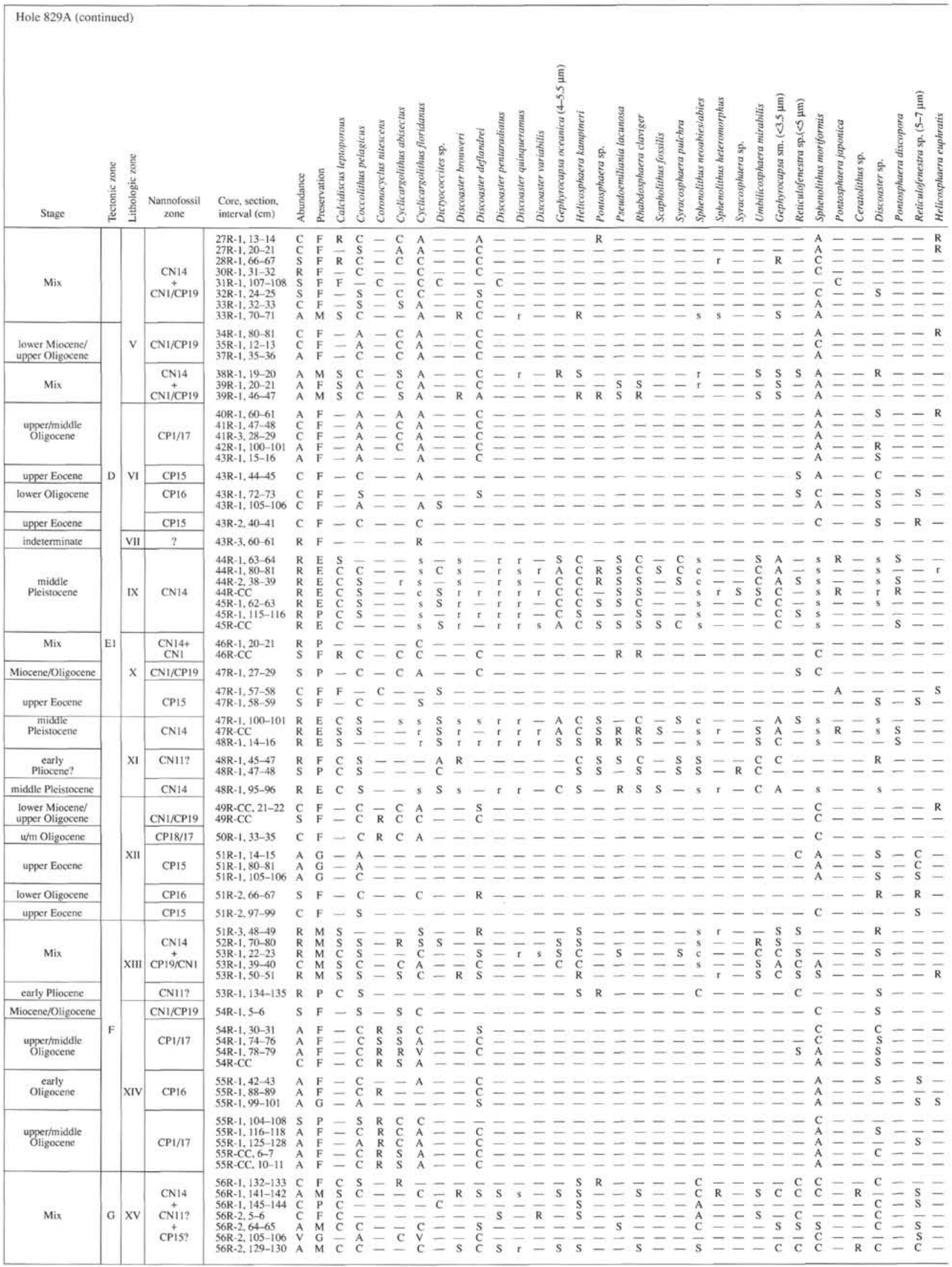




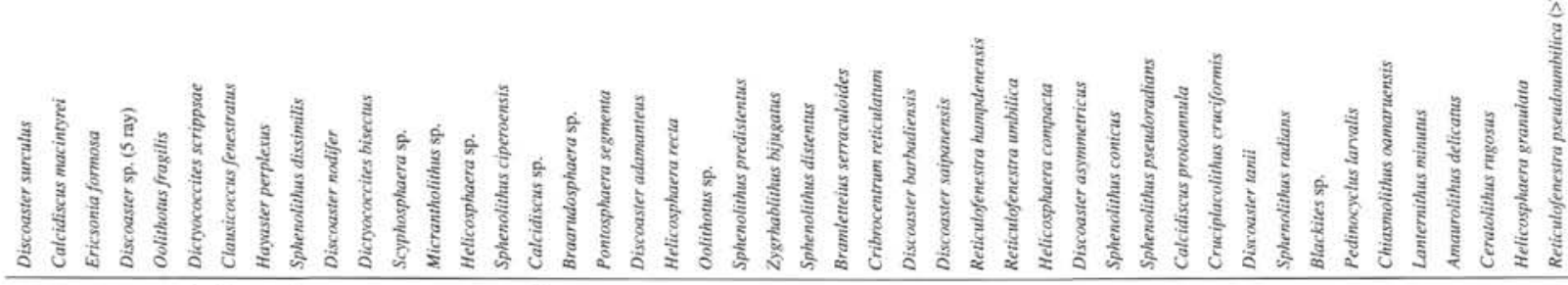

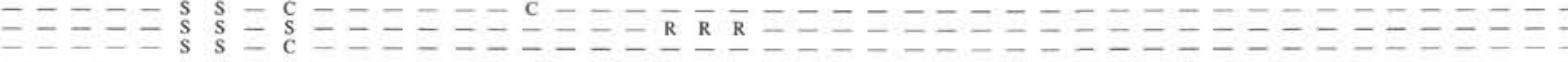

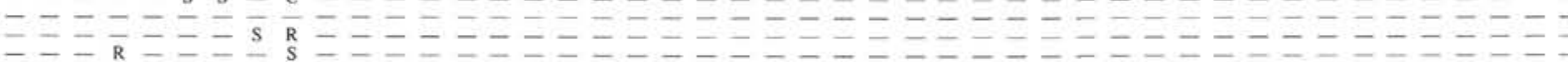

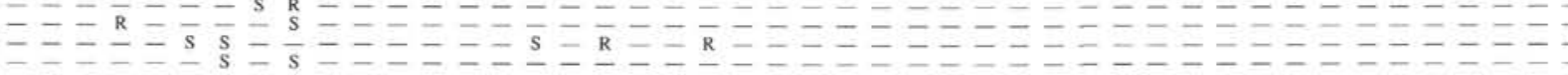

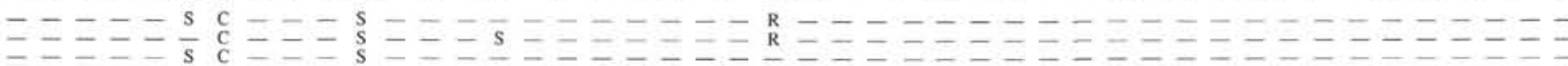

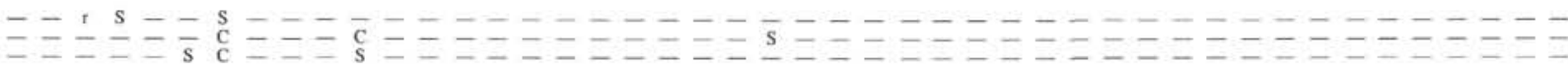
I

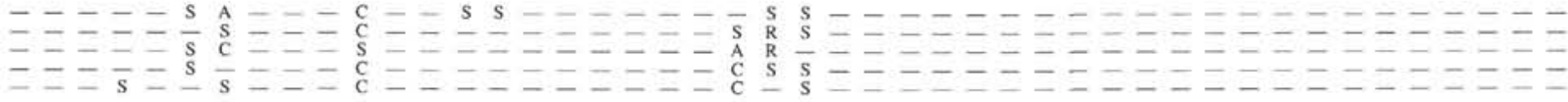
$--\mathrm{s} s-\mathrm{s} \ldots--\mathrm{c}-\ldots-\ldots-\ldots--\mathrm{c}--\mathrm{s} s \mathrm{~s} s \mathrm{~s} s$

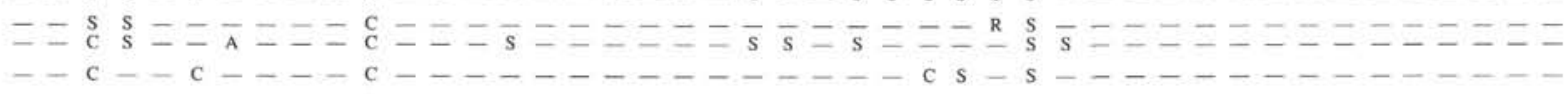

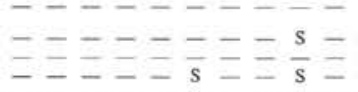

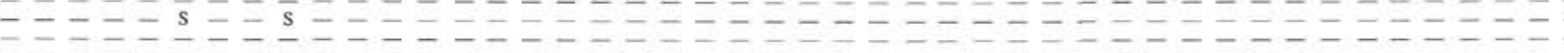

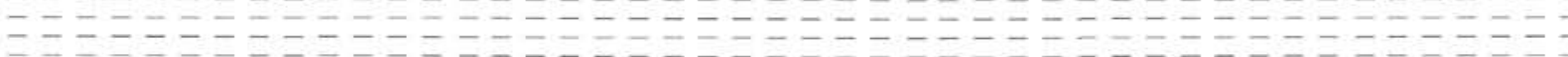

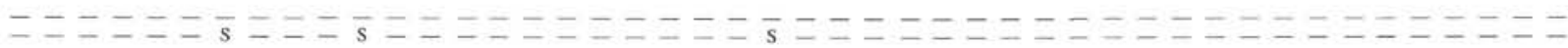

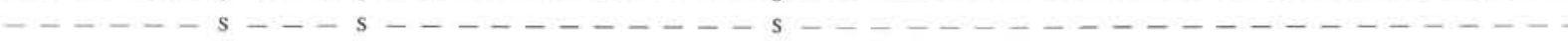

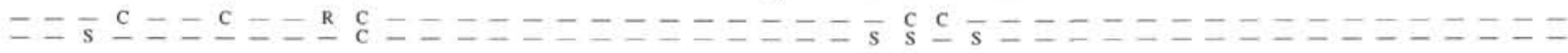

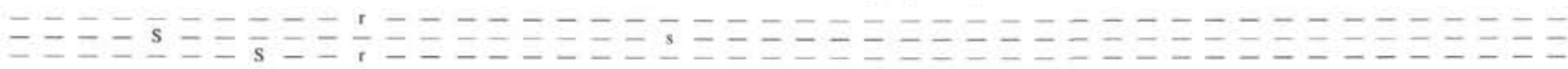
IR

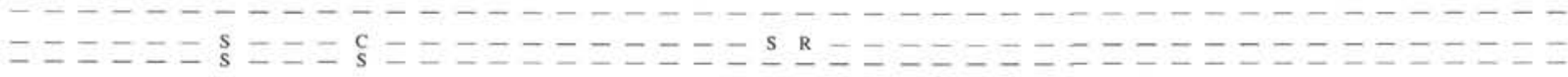

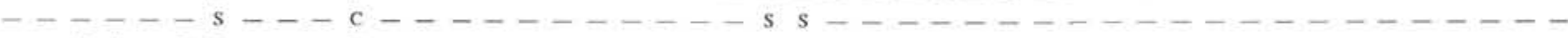

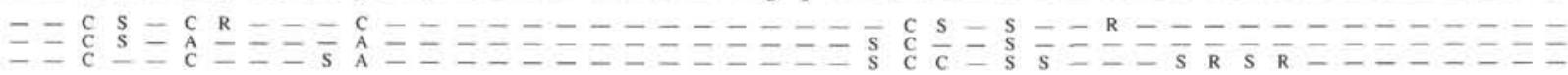

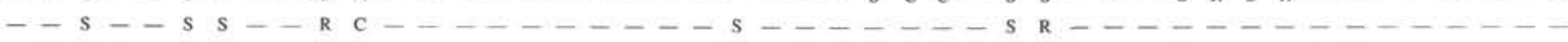
- s s - s

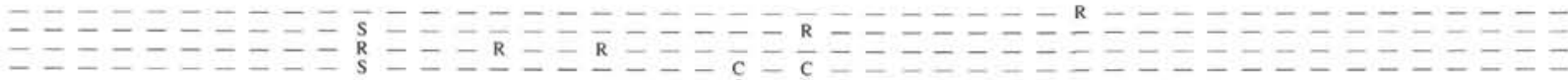
ニニニニニニニニニー

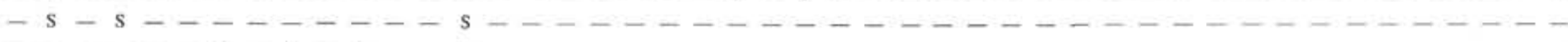

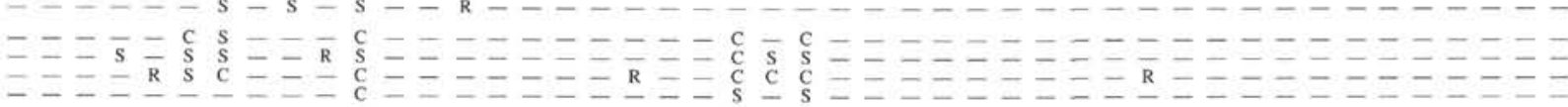

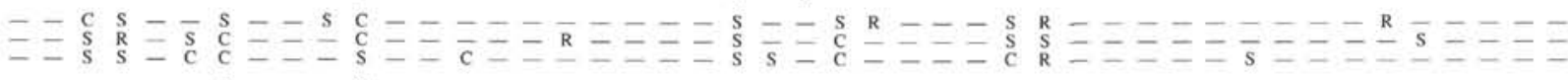

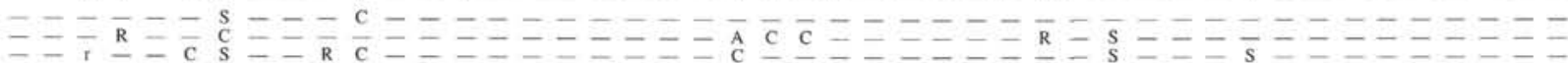

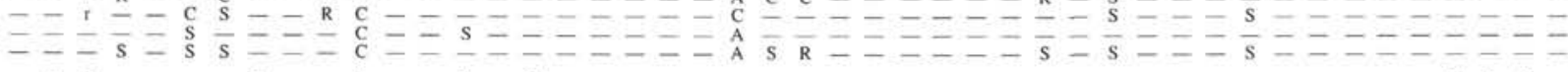

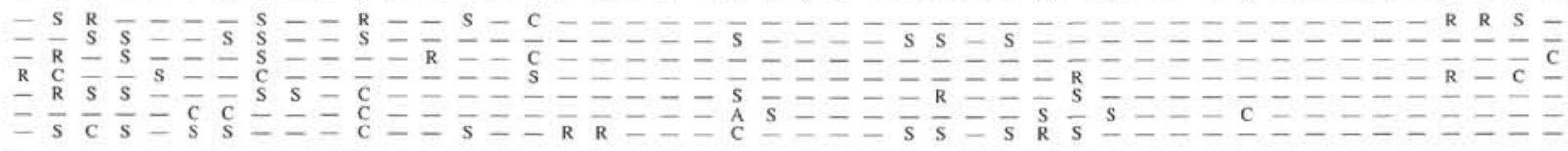




\begin{tabular}{|c|c|c|c|c|c|}
\hline Age & $\begin{array}{r}\text { Zo } \\
\text { (Okada and Bukg, 1980) }\end{array}$ & (Marini, 1971) & $\begin{array}{l}\text { Core, section, } \\
\text { interval }(\mathrm{cm})\end{array}$ & $\begin{array}{l}\text { Depth } \\
\text { (mbsf) }\end{array}$ & Comments \\
\hline 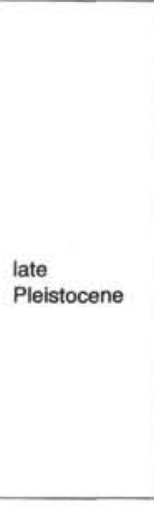 & CN15 & NN21 & \begin{tabular}{|l|}
$R-1,35-36$ \\
$1 R-2,35-36$ \\
$2 R-1,35-36$ \\
$2 R-2,35-36$ \\
$2 R-3,35-36$ \\
$3 R-1,35-36$ \\
$3 R-2,35-36$ \\
$3 R-3,35-36$ \\
$4 R-1,35-36$ \\
$4 R-2,35-36$ \\
$4 R-3,35-36$ \\
$4 R-4,35-36$ \\
$4 R-5,35-36$ \\
$5 R-3,35-36$ \\
$5 R-4,35-36$ \\
$5 R-5,35-36$ \\
$5 R-6,35-36$ \\
$6 R-1,35-36$ \\
$6 R-2,35-36$
\end{tabular} & \begin{tabular}{|l|}
$0.35-0.36$ \\
$1.85-1.86$ \\
$3.15-3.16$ \\
$4.65-4.66$ \\
$6.15-6.16$ \\
$12.65-12.66$ \\
$14.15-14.16$ \\
$15.65-15.66$ \\
$21.95-21.96$ \\
$23.45-23.46$ \\
$24.95-24.96$ \\
$26.45-26.46$ \\
$27.95-27.96$ \\
$34.35-34.36$ \\
$35.85-35.86$ \\
$37.35-37.36$ \\
$38.85-38.86$ \\
$41.45-41.46$ \\
$42.95-42.96$
\end{tabular} & $\begin{array}{c}\text { FADE. huxleyi } \\
0.28 \mathrm{Ma}\end{array}$ \\
\hline $\begin{array}{l}\text { middle } \\
\text { Pleistocene }\end{array}$ & CN14 & NN20 & $\begin{array}{l}6 \mathrm{R}-3,35-36 \\
6 \mathrm{R}-4,35-36 \\
6 \mathrm{R}-5,35-36 \\
6 \mathrm{R}-6,35-36 \\
6 \mathrm{R}-7,35-36 \\
7 \mathrm{R}-1,14-15 \\
7 \mathrm{R}-2,20-21\end{array}$ & \begin{tabular}{|l|}
$44.45-44.46$ \\
$45.95-45.96$ \\
$47.45-47.46$ \\
$48.95-48.96$ \\
$50.45-50.46$ \\
$50.94-50.95$ \\
$52.50-52.51$
\end{tabular} & $=0.28 \mathrm{mad}$ \\
\hline $\begin{array}{l}\text { early Miocene/ } \\
\text { late Oligocene }\end{array}$ & $\mathrm{CP} 19 / \mathrm{CN} 1$ & NN1/NP25 & $\begin{array}{l}\text { 8R-CC, 6-7 } \\
\text { 8R-CC, 29-30 } \\
\text { 9R-CC, 10-11 } \\
10 R-1,20-21 \\
11 R-C C, 8-9\end{array}$ & $\begin{array}{l}69.56-69.57 \\
69.79-69.80 \\
79.20-79.21 \\
79.90-79.91 \\
98.38-98.39\end{array}$ & No structural \\
\hline $\begin{array}{l}\text { late } \\
\text { Pleistocene }\end{array}$ & CN15 & NN21 & $\begin{array}{l}12 \mathrm{R}-1,80-81 \\
12 \mathrm{R}-2,80-81 \\
12 \mathrm{R}-3,80-81 \\
12 \mathrm{R}-4,80-81 \\
12 \mathrm{R}-5,80-81 \\
12 \mathrm{R}-6,80-81 \\
12 \mathrm{R}-7,24-25 \\
13 \mathrm{R}-1,70-71\end{array}$ & $\begin{array}{l}99.80-99.81 \\
101.30-101.31 \\
102.80-102.81 \\
104.30-104.31 \\
105.80-105.81 \\
107.30-107.31 \\
108.24-108.25 \\
109.30-109.31\end{array}$ & $\begin{array}{l}\text { evidence for } \\
\text { thrusting }\end{array}$ \\
\hline $\begin{array}{l}\text { middle } \\
\text { Pleistocene }\end{array}$ & CN14 & NN2O & $\begin{array}{l}13 R-2,70-71 \\
13 R-3,70-71 \\
13 R-4,70-71 \\
13 R-5,70-71 \\
13 R-6,70-71 \\
14 R-1,70-71 \\
14 R-2,104-105 \\
14 R-3,30-31 \\
14 R-4,76-77 \\
14 R-5,95-96\end{array}$ & $\begin{array}{l}110.80-110.81 \\
112.30-112.31 \\
113.80-113.81 \\
115.30-115.31 \\
116.80-116.81 \\
118.90-118.91 \\
120.74-120.75 \\
121.50-121.51 \\
123.46-123.47 \\
125.15-125.16\end{array}$ & \\
\hline
\end{tabular}

Figure 9. Nannofossil biostratigraphic summary of Hole 829A.

Greene, Stokking, et al., 1992), contains a mixture from both Zones $\mathrm{CN} 4$ and $\mathrm{CN} 14$. The dominant matrix material within the entire interval, however, is a Pleistocene siltstone of Zone CN14.

Beginning in Section 134-829A-21R-1 clasts of Zone CN4 are no longer present. Chalk clasts from the lowermost Miocene or uppermost Oligocene (CN1/CP19), which are listed in Appendix C, are common in Section 134-829A-21R-1 and below. The interclast sandy matrix as well as the sandy clasts contains a mix of the lower Miocene or upper Oligocene (CN1/CP19) and Pleistocene (CN14) species. Except for the difference in age of the clasts, lithologically this lower interval of clast-bearing sediments is indistinguishable from the middle Miocene clast-bearing interval beginning in Section 134-829A-19R-4.

From Samples 134-829A-24R-2, 21-22 cm, through -33R-1, 70$71 \mathrm{~cm},-38 \mathrm{R}-1,19-20 \mathrm{~cm}$, through $-39 \mathrm{R}-1,46-47 \mathrm{~cm}$, and $-46 \mathrm{R}-1$, $20-21 \mathrm{~cm}$, through $-46 \mathrm{R}-\mathrm{CC}$, the sediments reflect an increase in carbonate content concomitant with an appreciable reduction in the quantity of Pleistocene nannofossils (CN14). The chalk is highly brecciated with numerous chalk clasts of Miocene or Oligocene age (CN1/CP19), many of which are also composed of breccia (Collot, Greene, Stokking, et al., 1992; Reid et al., this volume). The matrix material is also chalk and contains dominant proportions of Miocene or Oligocene (CN1/CP19) nannofossils with sparse to rare occurrences of Pleistocene species (CN14).
The two additional intervals containing mixed-age sediments and some clasts are in Sections 134-829A-51R-3 to -53R-1 and 134829A-56R-1 to -56R-3 (Fig. 9, Table 5, and Appendix C). The dominant lithology of these intervals is volcanic sandstone and volcanic siltstone, respectively. In the uppermost interval, there are a few poorly preserved Pliocene(?) clasts within a matrix containing a mixture of Pleistocene Zone CN14 and Oligocene Zone CN17/18 materials. Some chalky layers contain up to approximately $70 \%$ Oligocene (CP18/17) nannofossil assemblages.

The lowermost nannofossil-bearing sediments cored at Hole 829A are from Sections 134-829A-56R-1 to -56R-3. These contain a large number of clasts and are similar to the siltstone-chalk breccia uphole. This interval contains both clasts and interclast matrix of varying compositions and ages (Appendix C). Clasts containing poorly preserved nannofossils representative of Zone $\mathrm{CN} 11$ or $\mathrm{CN} 10$ are present. A lamina of chalk containing well-preserved middle Oligocene nannofossils of Zone CP17/18 is also present. The interclast material appears to be a variable mix of several different assemblages including up to approximately $86 \%$ Eocene and $25 \%$ Pliocene forms. Pleistocene nannofossils are also present in the interclast matrix but constitute between approximately $5 \%$ and $10 \%$ of the overall assemblage. Excluding the clasts and interclast matrix, the dominant biostratigraphic zone represented over this entire interval is the Pleistocene Zone CN14 (Fig. 9). 


\begin{tabular}{|c|c|c|c|c|c|}
\hline \multirow[t]{2}{*}{ Age } & \multicolumn{2}{|c|}{ Zone } & \multirow[t]{2}{*}{$\begin{array}{l}\text { Core, section, } \\
\text { interval }(\mathrm{cm})\end{array}$} & \multirow[t]{2}{*}{$\begin{array}{l}\text { Depth } \\
\text { (mbsf) }\end{array}$} & \multirow[t]{2}{*}{ Comments } \\
\hline & (Okada and Bukry, 19e0) & (Martini, 1971) & & & \\
\hline \multirow{17}{*}{$\begin{array}{l}\text { middle } \\
\text { Pleistocene }\end{array}$} & \multirow{17}{*}{$\mathrm{CN} 4$} & \multirow{17}{*}{ NN20 } & 14R-6, 94-95 & $126.64-126.65$ & \multirow{26}{*}{$\begin{array}{l}\text { Structure } \\
\text { indicates a } \\
\text { minor fault }\end{array}$} \\
\hline & & & $14 \mathrm{R}-7,33-34$ & $127.20-127.21$ & \\
\hline & & & $15 \mathrm{R}-1,70-71$ & $128.60-128.61$ & \\
\hline & & & $15 R-2,71-72$ & $130.11-130.12$ & \\
\hline & & & $15 R-3,71-72$ & $131.61-131.62$ & \\
\hline & & & $15 \mathrm{R}-4,71-72$ & $133.11-133.12$ & \\
\hline & & & $15 R-5,71-72$ & $134.61-134.62$ & \\
\hline & & & $15 R-6,71-72$ & $136.11-136.12$ & \\
\hline & & & $15 \mathrm{R}-7,33-34$ & $137.23-137.24$ & \\
\hline & & & $16 \mathrm{R}-1,78-79$ & $138.28-138.29$ & \\
\hline & & & $16 \mathrm{R}-2,78-79$ & $139.78-138.79$ & \\
\hline & & & $16 \mathrm{R}-3,78-79$ & $141.28-141.29$ & \\
\hline & & & $16 \mathrm{R}-4,78-79$ & $142.78-142.79$ & \\
\hline & & & $16 \mathrm{~A}-5,78-79$ & $144.28-144.29$ & \\
\hline & & & $16 \mathrm{R}-6,78-79$ & $145.78-148.79$ & \\
\hline & & & $16 \mathrm{R}-7,32-33$ & $146.82-146.83$ & \\
\hline & & & $17 \mathrm{R}-1,40-41$ & $147.60-147.61$ & \\
\hline \multirow{9}{*}{$\begin{array}{l}\text { late } \\
\text { Pleistocene }\end{array}$} & \multirow{9}{*}{ CN15 } & \multirow{9}{*}{ NN21 } & $17 R-2,40-41$ & $149.10-149.11$ & \\
\hline & & & $17 \mathrm{R}-3,40-41$ & $150.60-150.61$ & \\
\hline & & & $17 R-4,40-41$ & $152.10-152.11$ & \\
\hline & & & $17 \mathrm{R}-5,40-41$ & $153.60-153.61$ & \\
\hline & & & 17R-6, $40-41$ & $155.10-155.11$ & \\
\hline & & & 17R-7, $40-41$ & $156.60-156.61$ & \\
\hline & & & $18 R-1,40-41$ & $157.20-157.21$ & \\
\hline & & & $18 R-2,40-41$ & $158.70-158.71$ & \\
\hline & & & $18 R-3,40-41$ & $160.20-160.21$ & \\
\hline \multirow{8}{*}{$\begin{array}{l}\text { middle } \\
\text { Pleistocene }\end{array}$} & \multirow{8}{*}{ CN14 } & \multirow{8}{*}{ NN2O } & $18 \mathrm{R}-4,40-41$ & $161.70-161.71$ & \multirow{8}{*}{ Numerous clasts } \\
\hline & & & $18 R-5,40-41$ & 163.20-163.21 & \\
\hline & & & $18 \mathrm{R}-6,40-41$ & $164.70-164.71$ & \\
\hline & & & 19R-1, 64-65 & $167.14-167.15$ & \\
\hline & & & 19R-2, 71-72 & $168.71-168.72$ & \\
\hline & & & $19 \mathrm{R}-3,49-50$ & $169.99-170.00$ & \\
\hline & & & $19 R-4,86-87$ & $171.86-171.87$ & \\
\hline & & & 20R-2, 112-113 & $178.72-178.73$ & \\
\hline \multirow{3}{*}{ Mixed ages } & \multirow{3}{*}{$\mathrm{CN} 4+\mathrm{CN}_{14}$} & \multirow{3}{*}{$\mathrm{NN5}+\mathrm{NN} 20$} & $21 \mathrm{R}-1,75-76$ & $186.55-186.56$ & \multirow{13}{*}{$\begin{array}{l}\text { Structure suggests } \\
\text { major thrust zone } \\
\text { with small scale } \\
\text { reverse faults }\end{array}$} \\
\hline & & & $21 R-2,73-74$ & $188.03-188.04$ & \\
\hline & & & $22 R-2,45-46$ & $197.45-197.46$ & \\
\hline \multirow{2}{*}{$\begin{array}{l}\text { late Oligocene/ } \\
\text { early Miocene }\end{array}$} & \multirow{2}{*}{$\mathrm{CP} 19 / \mathrm{CN} 1$} & NN1/NP25 & $23 \mathrm{~A}-1,46-47$ & $205.66-205.67$ & \\
\hline & & NN1/NP25 & $23 \mathrm{R}-2,19-20$ & 206.89-206.90 & \\
\hline Mixed ages & $\mathrm{CN} 4+\mathrm{CN} 14$ & $\mathrm{NN5}+\mathrm{NN} 2 \mathrm{O}$ & $24 \mathrm{R}-1,80-81$ & $215.70-215.71$ & \\
\hline & & & 24R-2, 21-22 & 216.61-216.62 & \\
\hline & & & $\begin{array}{l}25 \mathrm{R}-1,20-21 \\
26 \mathrm{R}-1,56-57\end{array}$ & $\begin{array}{l}224.81-224.82 \\
234.86-234.87\end{array}$ & \\
\hline & $\mathrm{CP} 19 / \mathrm{CN} 1$ & NN1/ NP25 & 26R-2, 13-14 & 235.93-235.94 & \\
\hline Mixed ages & + & + & $27 \mathrm{R}-1,13-14$ & $244.03-244.04$ & \\
\hline & CN14 & NN2O & 27R-2, 20-21 & $245.60-245.61$ & \\
\hline & & & $28 \mathrm{R}-1,66-67$ & $254.26-254.27$ & \\
\hline & & & 33R-1, 70-71 & $302.50-302.51$ & \\
\hline
\end{tabular}

Figure 9 (continued).

\section{Site 830}

Sites 830 and 831 were drilled to investigate the collision of the Bougainville Guyot with the New Hebrides Island Arc. Pre-cruise investigations suggested that the forearc deformation at Site 830 was more intensely developed than along the NDR/arc collisional Sites 827 and 829 (Collot and Fisher, 1989). One objective in drilling Sites 830 and 831 was to document the type of sediment from a reference site on the Bougainville Guyot (Site 831) and to determine the amount of accreted guyot material present in the forearc (Site 830).

Most samples analyzed from Site 830 were devoid of nannofossils except the uppermost 13 cores (Fig. 10 and Table 6), which are composed of gray, hemipelagic, graded Pleistocene silts and clays. Shorebased investigations revealed no biostratigraphic evidence to suggest the presence of repeated sections at this site; however, one suspected unconformity was recorded. As with the Pleistocene sections at Sites 827 and 829 , both the nannofossil and foraminiferal biostratigraphic interpretations were hindered by reworking.

Between Samples 134-830A-1H-1, 60-61 cm, and -2H-3, 110-111 $\mathrm{cm}$, an assemblage containing Gephyrocapsa oceanica, Helicosphaera kamptneri, Calcidiscus leptoporus, Rhabdosphaera claviger, Scapholithus fossilis, Umbilicosphaera mirabilis, Syracosphaera pulchra, Ceratolithus cristatus (rare), and the late Pleistocene zonal marker Emiliania huxleyi indicates Zone CN15. The abrupt first oc- currence of E. huxleyi in Sample 134-830A-2H-3, 110-111 cm, coincident with shipboard sedimentological reports of oxidation across this interval (Collot, Greene, Stokking, et al., 1992) suggests the presence of an unconformity at 11.85 mbsf.

In Sample 134-830A-2H-4, 110-111 cm, E. huxleyi is absent indicating the beginning of Zone CN14b. Zone $14 \mathrm{~b}$ continues through Sample 134-830A-2H-6, 30-31 cm, below which P. lacunosa is common, signifying the beginning of Zone CN14a. The accompanying assemblage is the same as reported from the overlying zone. Zone CN14a continues until a paucity of nannofossils below Sample 134830 A-13R-2, 14-15 cm, prevents age determinations.

\section{BIOSTRATIGRAPHY OF THE NORTH AOBA BASIN}

\section{Basin Center}

\section{Site 832}

Site 832 was drilled in the North Aoba Basin (NAB) to investigate how arc-ridge collision affected the formation of the intra-arc basin. The primary paleontologic objectives for this site were to determine the age of the basin fill and the age of a major unconformity. The unconformity is clearly discernable on seismic reflection profiles and is believed to coincide with the initial collision of the NDR with 


\begin{tabular}{|c|c|c|c|c|c|}
\hline Age & Zo & (Martini 1971) & $\begin{array}{l}\text { Core, section, } \\
\text { interval }(\mathrm{cm})\end{array}$ & $\begin{array}{l}\text { Depth } \\
\text { (mbsf) }\end{array}$ & Comments \\
\hline Mixed ages & $\mathrm{CN} 1+\mathrm{CN}_{1} 14$ & $\mathrm{NN} 1+\mathrm{NN} 20$ & $\begin{array}{l}28 \mathrm{R}-1,66-67 \\
33 \mathrm{R}-1,70-71\end{array}$ & $\begin{array}{l}254.26-254.27 \\
302.50-302.51\end{array}$ & Scaly fabric \\
\hline $\begin{array}{l}\text { early Miocene/ } \\
\text { late Oligocene }\end{array}$ & CP19/ CN1 & NN1/ NP25 & $\begin{array}{l}34 \mathrm{R}-1,80-81 \\
35 \mathrm{R}-1,12-13 \\
35 \mathrm{R}-1,73-74 \\
37 \mathrm{R}-1,35-36\end{array}$ & \begin{tabular}{|l|}
$312.10-312.11$ \\
$320.62-320.63$ \\
$321.23-321.24$ \\
$340.15-340.16$
\end{tabular} & \\
\hline Mixed ages & $\mathrm{CN} 1+\mathrm{CN} 14$ & $\mathrm{NN1}+\mathrm{NN20}$ & $\begin{array}{l}38 R-1,19-20 \\
39 R-1,20-21 \\
39 R-1,46-47\end{array}$ & \begin{tabular}{|l|}
$349.69-349.70$ \\
$359.30-359.31$ \\
$359.56-359.57$
\end{tabular} & Rare scaly fabric \\
\hline Oligocene & CP17/18 & NP23 & $\begin{array}{l}40 R-1,60-61 \\
41 \mathrm{R}-1,47-48 \\
41 \mathrm{R}-3,28-29 \\
42 \mathrm{R}-1,100-101 \\
43 \mathrm{R}-1,15-16\end{array}$ & \begin{tabular}{|l|}
$369.40-369.41$ \\
$378.87-378.88$ \\
$383.18-383.14$ \\
$389.10-389.11$ \\
$397.85-397.86$
\end{tabular} & $\begin{array}{l}\text { Top of major } \\
\text { shear zone }\end{array}$ \\
\hline late Eocene & CP15 & NP2O & $43 \mathrm{R}-1,44-45$ & 398.14-398.15 & Shearing with \\
\hline early Oligocene? & CP16? & NP19? & $\begin{array}{l}43 R-1,72-73 \\
43 R-1,105-106\end{array}$ & \begin{tabular}{|l|}
$398.42-398.43$ \\
$398.75-398.76$
\end{tabular} & scaly fabric \\
\hline $\begin{array}{l}\text { late Eocene } \\
\text { Indeterminatel }\end{array}$ & ${ }^{\mathrm{CP} 15}$ & $\begin{array}{l}\text { NP20 } \\
\text { BEN }\end{array}$ & $\begin{array}{l}43 \mathrm{R}-2,40-41 \\
43 \mathrm{R}-3,60-61\end{array}$ & $\begin{array}{l}399.60-399.61 \\
401.30-401.31\end{array}$ & $\begin{array}{l}\text { Base of major } \\
\text { shear zone }\end{array}$ \\
\hline late Pliocene? & CN11? & NN15? & $44 \mathrm{~A}-1,26-27$ & $407.66-407.67$ & \\
\hline $\begin{array}{l}\text { middle to lower } \\
\text { Pleistocene }\end{array}$ & CN14 & NN2O & $\begin{array}{l}44 \mathrm{R}-1,63-64 \\
44 \mathrm{R}-1,80-81 \\
44 \mathrm{R}-2,38-39 \\
44 \mathrm{R}-\mathrm{CC} \\
45 \mathrm{R}-1,62-63 \\
45 \mathrm{R}-1,115-117 \\
45 \mathrm{R}-\mathrm{CC}\end{array}$ & $\begin{array}{l}408.03-408.04 \\
408.20-408.21 \\
409.28-409.29 \\
416.59-416.60 \\
417.22-417.23 \\
417.75-417.77 \\
421.59-421.60\end{array}$ & \\
\hline Mixed ages & $\mathrm{CN} 1+\mathrm{CN}_{14}$ & $\mathrm{NN} 1+\mathrm{NN} 20$ & $\begin{array}{l}46 \mathrm{R}-1,20-21 \\
46 \mathrm{R}-\mathrm{CC}\end{array}$ & $\begin{array}{l}421.80-421.81 \\
426.59-426.60\end{array}$ & \\
\hline Mio_/Olig. & CP19/CN1 & NN1/NP25 & $47 \mathrm{~A}-1,27-29$ & $426.87-426.88$ & Shearing with \\
\hline late Eocene & CP15 & NP20 & $\begin{array}{l}47 \mathrm{~A}-1,57-58 \\
47 \mathrm{R}-1,58-59\end{array}$ & $\begin{array}{l}427.17-427.18 \\
427.18-427.19\end{array}$ & scaly fabric \\
\hline Pleistocene & CN14 & NN2O & $\begin{array}{l}47 \mathrm{R}-1,100-101 \\
47 \mathrm{R}-\mathrm{CC} \\
48 \mathrm{R}-1,14-16\end{array}$ & $\begin{array}{l}427.60-427.61 \\
436.29-436.30 \\
436.44-436.45\end{array}$ & \\
\hline late Pliocene ? & CN11? & NN15? & $\begin{array}{l}48 \mathrm{R}-1,45-47 \\
48 \mathrm{R}-1,47-48\end{array}$ & $\begin{array}{l}467.44-467.45 \\
467.45-467.46\end{array}$ & \\
\hline Pleistocene & CN14 & NN2O & 48R-1, $95-96$ & $\mid \begin{array}{l}40.75-407.40 \\
437.25-437.26\end{array}$ & \\
\hline $\begin{array}{l}\text { early Miocene/ } \\
\text { late Oligocene }\end{array}$ & CP19/ CN1 & NN1/ NP25 & $\begin{array}{l}\text { 49R-CC, 21-22 } \\
\text { 49R-CC }\end{array}$ & \begin{tabular}{|l|}
$446.11-446.12$ \\
$455.59-455.60$
\end{tabular} & \\
\hline Oligocene & CP17/18 & NP23 & $50 \mathrm{R}-1,33-35$ & 455.93-455.94 & \\
\hline late Eocene & CP15 & NP2O & $\begin{array}{l}51 \mathrm{R}-1,14-15 \\
51 \mathrm{R}-1,80-81 \\
51 \mathrm{R}-1,105-106 \\
51 \mathrm{R}-2,97-98\end{array}$ & \begin{tabular}{|l|}
$460.24-460.25$ \\
$460.90-460.91$ \\
$461.15-461.16$ \\
$462.57-462.58$
\end{tabular} & \\
\hline
\end{tabular}

Figure 9 (continued).

the forearc off Espiritu Santo Island, due west of the NAB (Greene and Johnson, 1988; Fisher et al., 1988; Collot, Greene, Stokking, et al., 1992).

Both nannofossil abundance and the degree of reworking are highly variable at Site 832 . In fact, the paucity of nannofossils resulting from the input of voluminous quantities of volcanic material into the NAB severely limits the biostratigraphic utility of some samples. In addition to dilution, displacement of assemblages by both particle reworking and mass wasting also hinders biostratigraphic interpretations. Nevertheless, shore-based nannofossil analyses have augmented the shipboard data sufficiently to provide the required age control on the seismic stratigraphy.

As with the forearc drill sites, some age interpretations were revised following shore-based analyses, particularly for Pleistocene and upper Pliocene samples in which it was difficult aboard ship to distinguish LAD's because of reworking. A second significant deviation from the shipboard interpretations involves the lowermost cores retrieved from Site 832, which are now believed to be entirely displaced by slumping (discussed below).

Cores retrieved from Holes $832 \mathrm{~A}$ and $832 \mathrm{~B}$ range from latest Pleistocene to middle Miocene in age. Preservation is excellent in the Pleistocene sediments with preservation generally deteriorating downhole. Nannofossil abundances fluctuate from sparse to barren, which reflect the amount of dilution predominately from volcanic silt and sand. Abundances and preservation are given in Table 7. A summary of the biostratigraphic interpretations is provided herein (Fig. 11 and Table 7).

\section{Pleistocene}

Samples 134-832A-1H-1, 110-111 cm, through -7H-6, 56-57 cm, contain the same uppermost Pleistocene assemblage described for the Emiliania huxleyi Zone (CN15) at the previous sites. Neogene specimens of Discoaster brouweri, Calcidiscus macintyrei, Discoaster pentaradiatus, Sphenolithus abies/neoabies, and Discoaster variabilis are commonly present as reworked components.

In Sample 134-832A-8H-1, 70-71 cm, through the remainder of Hole $832 \mathrm{~A}$, the nannofossil assemblage is dominated by Gephyrocapsa oceanica, Rhabdosphaera claviger, Helicosphaera kamptneri, and $C$. leptoporus. Neogene and possibly Paleogene specimens occur as sporadic reworked specimens as evidenced by the presence of D. brouweri, $D$. variabilis, $S$. abies/neoabies, $D$. pentaradiatus, and Cyclicargolithus floridanus.

The middle Pleistocene nannofossil assemblage $\mathrm{CN} 14 \mathrm{~b}$ in the lower portion of Hole 832A continues into Hole 832B until Pseudoemiliania lacunosa becomes a common constituent of the assemblage beginning in Sample 134-832B-26R-1, 46-47 cm. Owing to the lack of core recovery in Cores 134-832B-24R and -25R, the placement of this datum higher than Core 134-832B-26R remains uncertain. Also, some of the specimens of $P$. lacunosa recorded upsection might be in 


\begin{tabular}{|c|c|c|c|c|c|}
\hline \multirow{2}{*}{ Age } & \multicolumn{2}{|c|}{ Zone } & \multirow{2}{*}{$\begin{array}{l}\text { Core, section, } \\
\text { interval }(\mathrm{cm})\end{array}$} & \multirow{2}{*}{$\begin{array}{l}\text { Depth } \\
\text { (mbsf) }\end{array}$} & \multirow[t]{2}{*}{ Comments } \\
\hline & (Okada and Bukry, 1990) & (Martini, 1971) & & & \\
\hline Mixed ages & $\mathrm{CN} 1+\mathrm{CN}_{14}$ & $\mathrm{NN} 1+\mathrm{NN} 20$ & $\begin{array}{l}51 R-3,48-49 \\
52 R-1,78-79 \\
53 R-1,22-23 \\
53 R-1,39-40 \\
53 R-1 \text { 50-51 }\end{array}$ & $\begin{array}{l}463.58-463.59 \\
465.98-465.99 \\
475.02-475-03 \\
475.19-475.20 \\
475.30-475.31\end{array}$ & \\
\hline late Oligocene & CP19/CN1 & NP24/NN1 & $54 \mathrm{R}-1,5-6$ & $484.55-484.56$ & Highly brecciated: \\
\hline $\begin{array}{l}\text { middle/late } \\
\text { Oligocene }\end{array}$ & $\mathrm{CP} 17 / 18$ & NP23 & $\begin{array}{l}54 R-1,30-31 \\
54 R-1,74-75 \\
54 R-1,78-79 \\
54 R-C C\end{array}$ & $\begin{array}{l}484.80-484.81 \\
485.24-485.25 \\
485.28-485.29 \\
494.09-494.10\end{array}$ & Scaly fabric \\
\hline early Oligocene & CP16 & NP22 & $\begin{array}{l}55 R-1,42-44 \\
55 R-1,99-100\end{array}$ & \begin{tabular}{|l|}
$494.52-494.53$ \\
$495.09-495.10$
\end{tabular} & \\
\hline $\begin{array}{l}\text { middle/late } \\
\text { Oligocene }\end{array}$ & CP17/18 & NP23 & $\begin{array}{l}55 R-1,104-105 \\
55 R-1,116-117 \\
55 R-1,125-126 \\
55 R-C C, 6-7 \\
55 R-C C, 10-12\end{array}$ & $\begin{array}{l}495.14-495.15 \\
495.26-495.27 \\
495.35-495.36 \\
495.47-495.48 \\
495.51 / 495.53\end{array}$ & $\begin{array}{l}\text { High-angle } \\
\text { microfaulting }\end{array}$ \\
\hline Pleistocene & CN14 & NN20 & $\begin{array}{l}56 \mathrm{R}-1,141-142 \\
56 \mathrm{R}-2,64-65 \\
56 \mathrm{R}-3,34-35\end{array}$ & $\begin{array}{l}505.21-505.22 \\
505.94-505.95 \\
507.14-507.15\end{array}$ & $\begin{array}{l}\text { Numerous clasts } \\
\text { (ages in Appendix C) }\end{array}$ \\
\hline
\end{tabular}

Figure 9 (continued).

A

\begin{tabular}{|c|c|c|c|c|c|}
\hline \multirow[t]{2}{*}{ Age } & \multicolumn{2}{|c|}{ Zone } & \multirow{2}{*}{$\begin{array}{l}\text { Core, section, } \\
\text { interval }(\mathrm{cm})\end{array}$} & \multirow{2}{*}{$\begin{array}{l}\text { Depth } \\
\text { (mbsf) }\end{array}$} & \multirow[t]{2}{*}{ Datum } \\
\hline & (Okada and Bukry, 1980) & (Martini, 1971) & & & \\
\hline \multirow{7}{*}{$\begin{array}{l}\text { late } \\
\text { Pleistocene }\end{array}$} & \multirow{7}{*}{ CN15 } & \multirow{7}{*}{ NN21 } & \multirow{17}{*}{$\begin{array}{l}1 \mathrm{H}-1,60-61 \\
1 \mathrm{H}-2,60-61 \\
1 \mathrm{H}-3,60-61 \\
1 \mathrm{H}-4,60-61 \\
2 \mathrm{H}-1,30-31 \\
2 \mathrm{H}-2,30-31 \\
2 \mathrm{H}-3,110-111 \\
2 \mathrm{H}-4,110-111 \\
2 \mathrm{H}-5,110-111 \\
2 \mathrm{H}-6,30-31 \\
3 \mathrm{H}-1,100-101 \\
4 \mathrm{H}-1,142-413 \\
4 \mathrm{H}-3,76-77 \\
5 \mathrm{H}-1,132-133 \\
5 \mathrm{H}-6,78-79 \\
6 \mathrm{X}-1,108-109 \\
6 \mathrm{X}-6,12-13 \\
7 \mathrm{X}-1,6-8 \\
8 \mathrm{X}-\mathrm{CC}, 8-9\end{array}$} & \multirow{17}{*}{$\begin{array}{l}0.60-0.61 \\
2.10-2.11 \\
3.60-3.61 \\
5.10-5.11 \\
7.30-7.31 \\
8.80-8.81 \\
11.10-11.12 \\
12.60-12.61 \\
14.10-14.11 \\
14.80-14.81 \\
17.50-17.51 \\
27.42-27.43 \\
29.76-29.77 \\
31.72-31.73 \\
38.68-38.69 \\
40.98-40.99 \\
47.52-47.53 \\
48.56-48.57 \\
67.28-67.29\end{array}$} & \multirow{9}{*}{......Unconformity..? ... } \\
\hline & & & & & \\
\hline & & & & & \\
\hline & & & & & \\
\hline & & & & & \\
\hline & & & & & \\
\hline & & & & & \\
\hline middle & & \multirow{10}{*}{ NN21 } & & & \\
\hline Pleistocene & CN14D & & & & \\
\hline \multirow{8}{*}{$\begin{array}{l}\text { middle/early } \\
\text { Pleistocene }\end{array}$} & \multirow{8}{*}{ CN14a } & & & & LAD P. lacunosa \\
\hline & & & & & \\
\hline & & & & & \\
\hline & & & & & \\
\hline & & & & & \\
\hline & & & & & \\
\hline & & & & & \\
\hline & & & & & \\
\hline
\end{tabular}

B

\begin{tabular}{|c|c|c|c|c|c|}
\hline \multirow{2}{*}{ Age } & \multicolumn{2}{|c|}{ Zone } & \multirow{2}{*}{$\begin{array}{l}\text { Core, section, } \\
\text { interval }(\mathrm{cm})\end{array}$} & \multirow{2}{*}{$\begin{array}{l}\text { Depth } \\
\text { (mbsf) }\end{array}$} & \multirow{2}{*}{ Datum } \\
\hline & (Okada and Bukry, 1980) & (Martin, 1971) & & & \\
\hline $\begin{array}{l}\text { middle/early } \\
\text { Pleistocene }\end{array}$ & $\mathrm{CN} 14 \mathrm{a}$ & NN21 & $\begin{array}{l}1 \mathrm{R}-2,22-23 \\
2 \mathrm{R}-1,104-105 \\
3 \mathrm{R}-1,93-94 \\
4 \mathrm{R}-2,40-41 \\
5 \mathrm{R}-2,85-86 \\
6 \mathrm{R}-1,45-46 \\
7 \mathrm{R}-1,20-21 \\
8 \mathrm{R}-1,100-101 \\
9 \mathrm{R}-1,89-90 \\
10 \mathrm{R}-2,30-31 \\
11 \mathrm{R}-2,16-17 \\
12 \mathrm{R}-2,107-108 \\
13 \mathrm{R}-2,14-15\end{array}$ & $\begin{array}{l}50.22-50.23 \\
59.14-59.15 \\
68.63-68.64 \\
79.40-79.41 \\
89.75-89.76 \\
97.55-97.56 \\
107.00-107.01 \\
117.50-117.51 \\
127.09-127.10 \\
137.70-137.71 \\
147.26-147.27 \\
156.37-156.38 \\
166.84-166.85\end{array}$ & \\
\hline
\end{tabular}

Figure 10. Nannofossil biostratigraphic summary. A. Hole 830A. B. Hole 830B.

situ, but are too sparse to be distinguished from reworked components (see Appendix A discussion). Although P. lacunosa is sparse throughout the upper portions of this hole, a shift in abundance from sparse to common and abundant below Sample 134-832B-26R-1, 46-47 cm, suggests that the $P$. lacunosa uphole are probably reworked.

Several intervals below the $P$. lacunosa datum in Hole 832B indicate disruptions in the normal stratigraphic sequence attributable to slumping. For instance, in Sample 134-832B-43R-2, 43-44 cm, and again in the interval from Sample 134-832B-46R-2, 107-108 cm, through -50R-3, 100-101 cm, Calcidiscus macintyrei appears without Gephyrocapsa oceanica and discoasters, which suggests that these sediments are of earliest Pleistocene or latest Pliocene age (Zone CN13); however, the reappearance of $G$. oceanica coincident with the disappearance of C. macintyrei in Sample 134-832B-50R-4, 


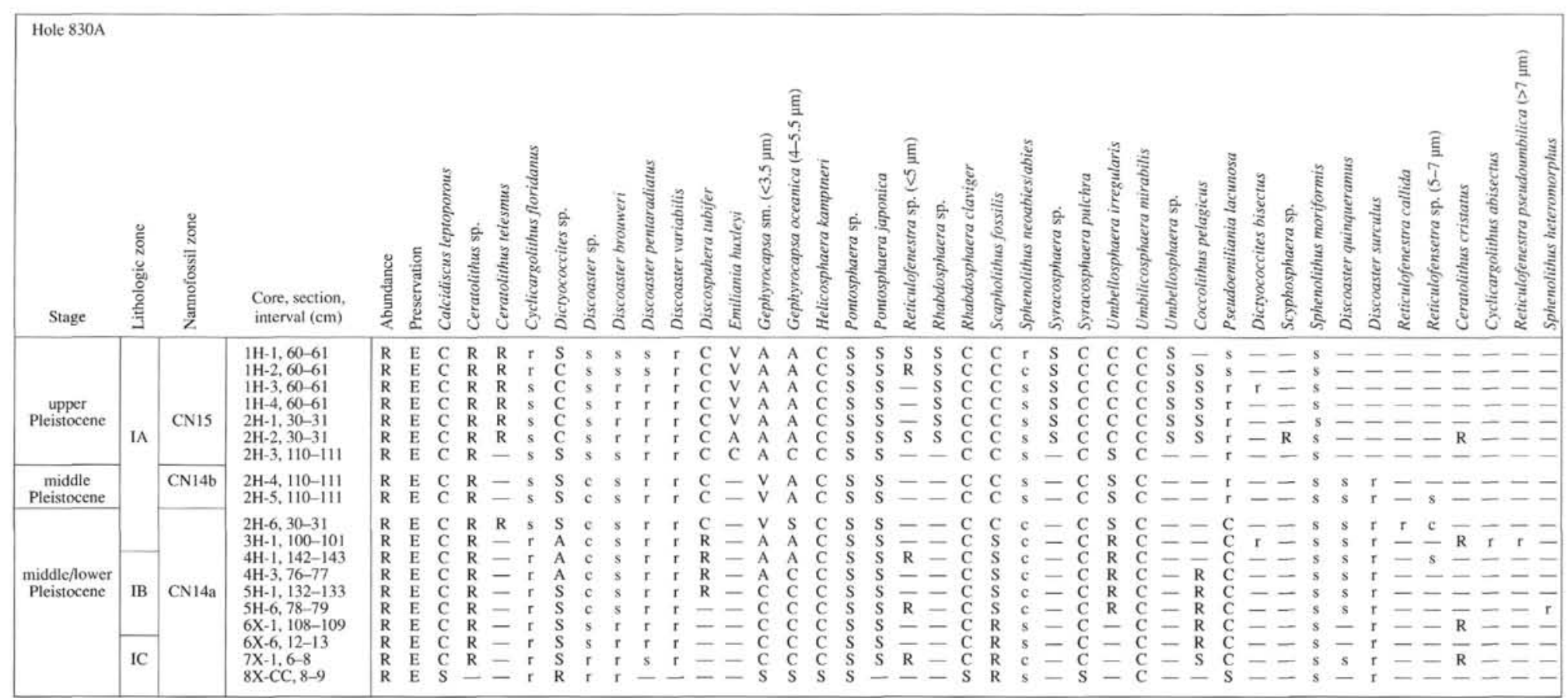

Table 6 (continued).

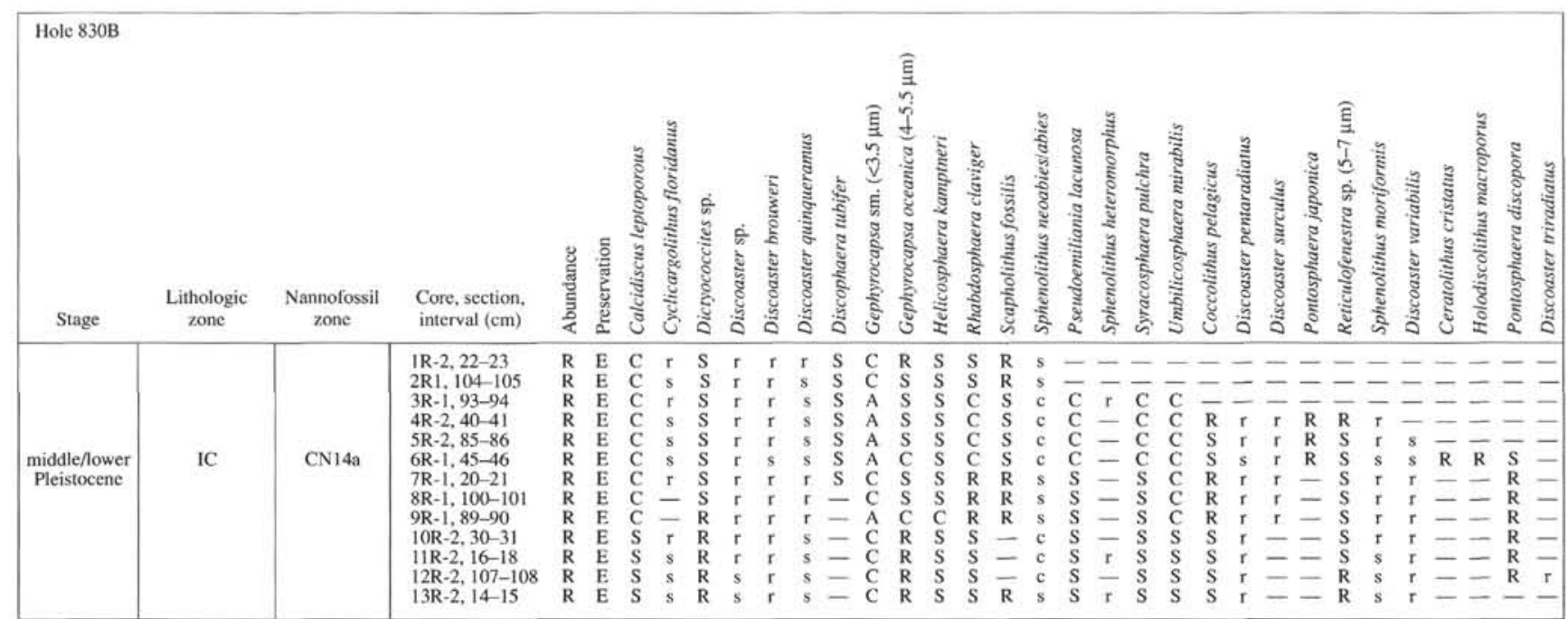


Table 7. Range charts for Site 832.

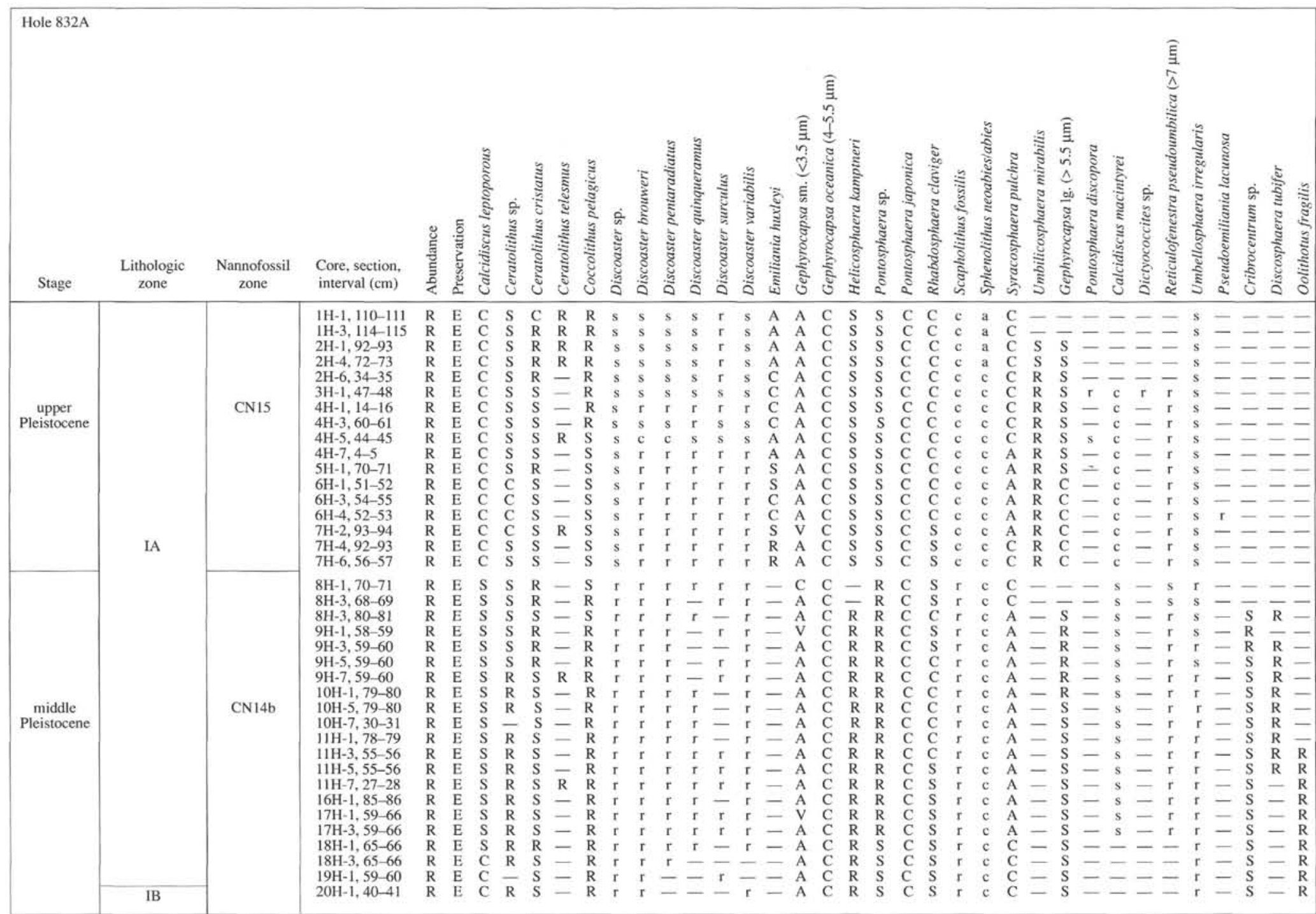


Table 7 (continued).

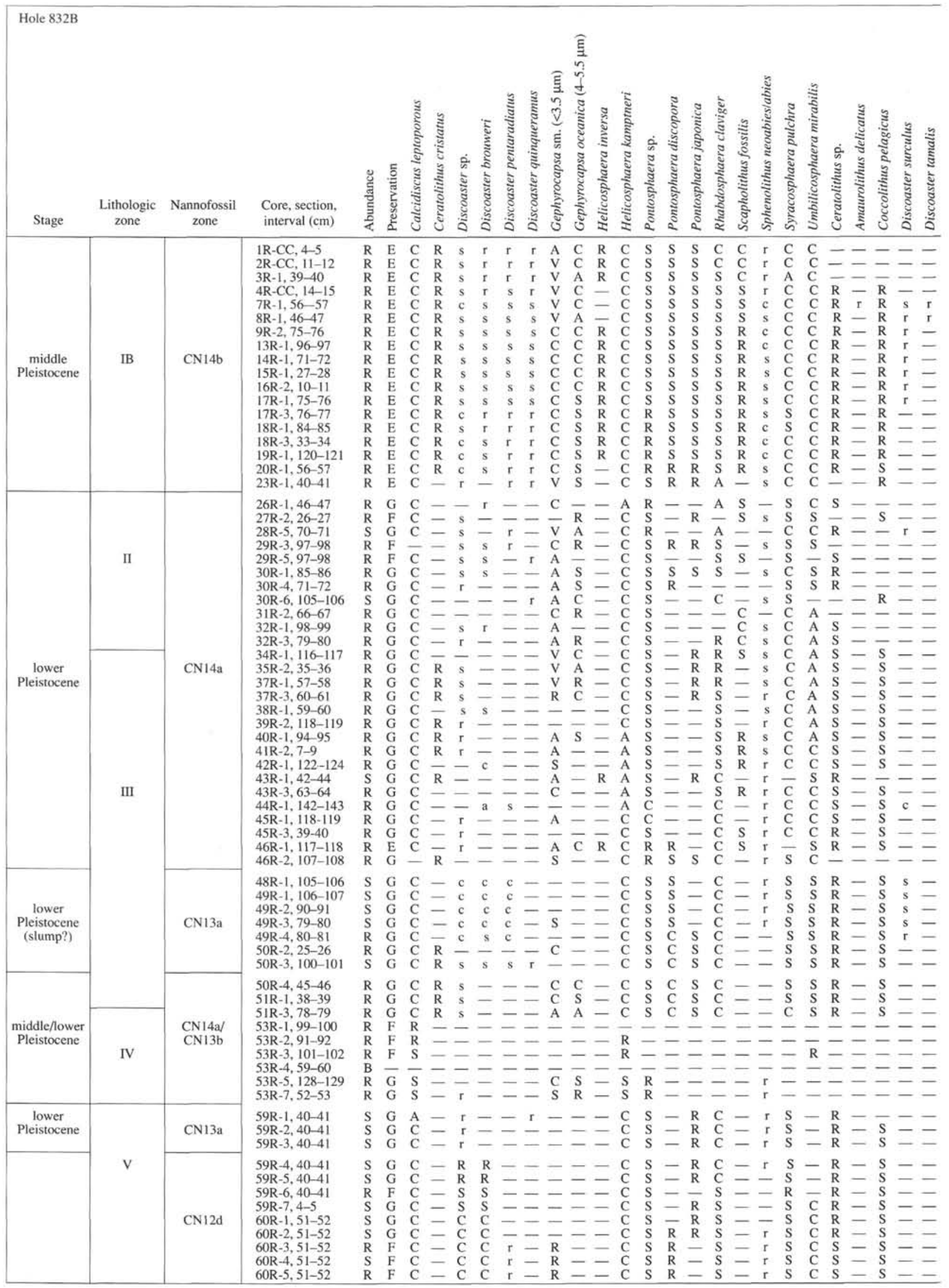




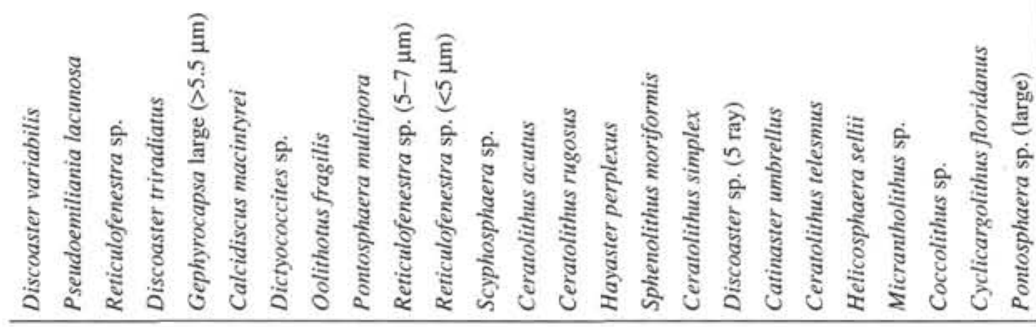
ニニニニニニニニニニニニニニニニニニニニニニニニニ - - - - - - - - - - - - - - - - - - -

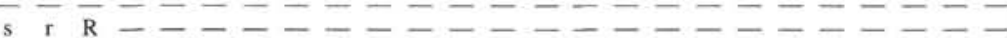

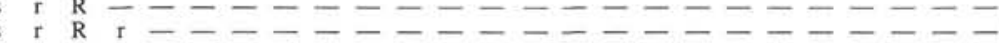
$\mathrm{r}-\ldots-\ldots-\ldots-1-\cdots$

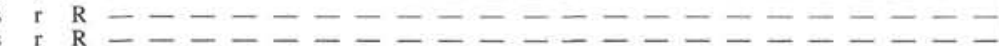

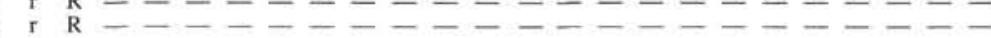

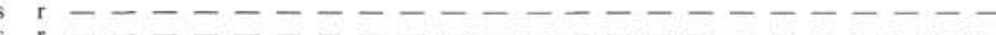
s $-1-1-1-1-1-1-1-1-1-1-1$

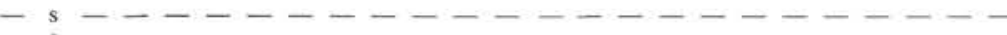

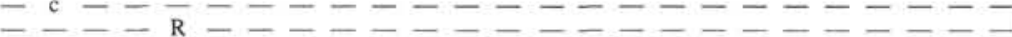

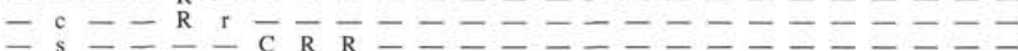

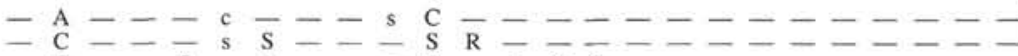
- $\mathrm{C}-\mathrm{C}-\mathrm{S}-\ldots \mathrm{r} \mathrm{C}-\mathrm{r} \mathrm{R} \mathrm{R}-\ldots-\ldots$

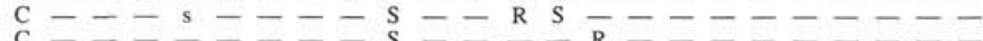

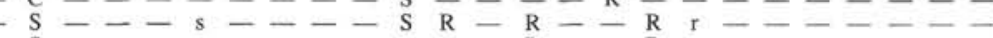
$-\mathrm{S}--------\frac{\mathrm{S}}{\mathrm{S}}-\mathrm{-} \mathrm{R}-\frac{\mathrm{R}}{\mathrm{R}}--\frac{\mathrm{r}}{\mathrm{R}}----$ $-\mathrm{C}---\overline{\mathrm{r}} \mathrm{C}---\mathrm{S}--\mathrm{R}-\mathrm{R} \mathrm{R}-\mathrm{r} \mathrm{R}----$

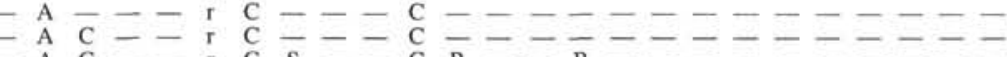

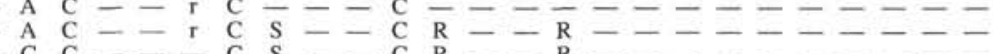

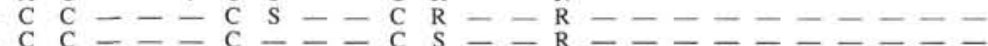

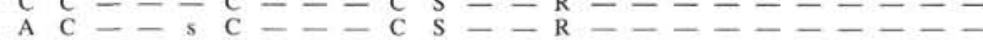

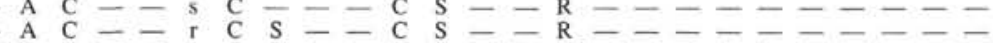

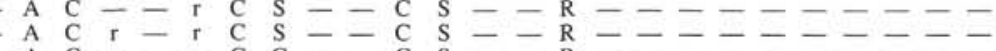

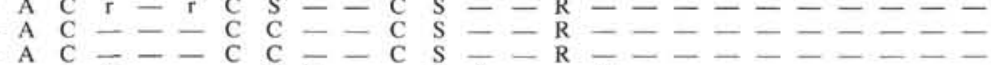

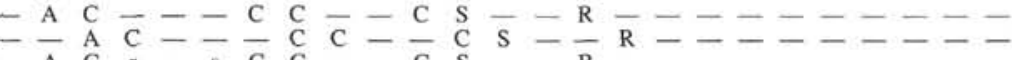
$-\mathrm{A} \mathrm{C} \mathrm{r}-\overline{\mathrm{S}} \mathrm{C} \mathrm{C}--\mathrm{C} \mathrm{S}-\overline{\mathrm{C}}-\overline{\mathrm{R}}--\ldots$

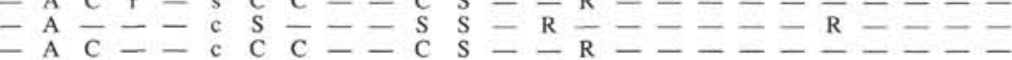

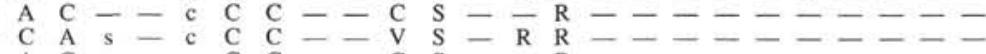

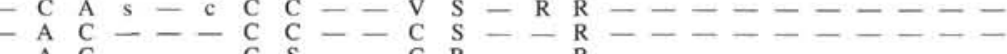

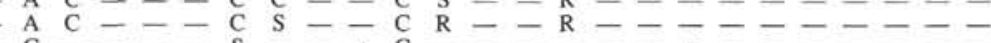

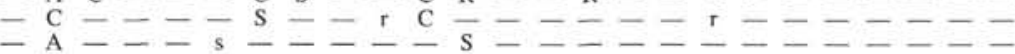

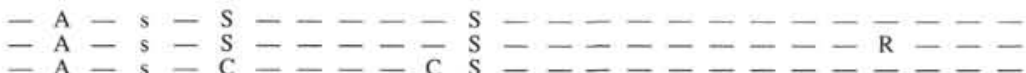

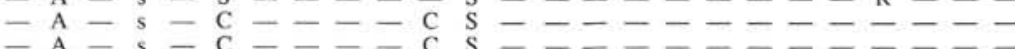

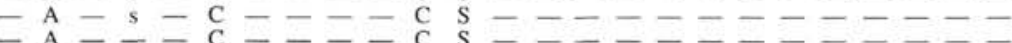

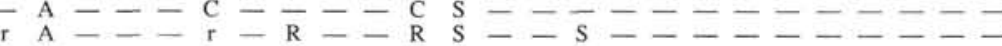

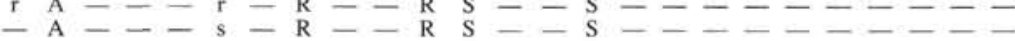
$-\mathrm{A}-----\mathrm{R}--\mathrm{R}-\mathrm{R} \mathrm{S}--\mathrm{S}---------$

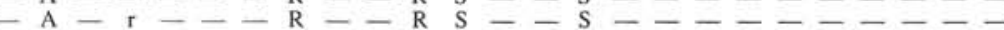
$-\mathrm{R}-1---1---1-1-1-\overline{\mathrm{R}}-\overline{-}$

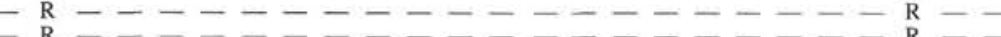

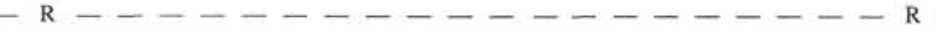

-

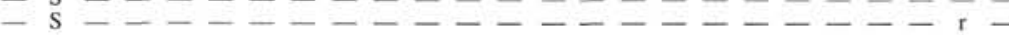

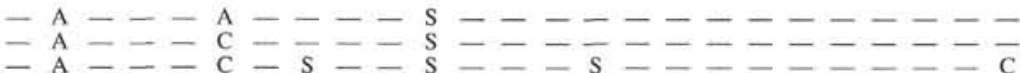
$\mathrm{r} A-\mathrm{R}-\mathrm{C}-\mathrm{S}--\mathrm{S}--\mathrm{S}----\cdots-\mathrm{C}$ $\mathrm{r}=\mathrm{A}-\mathrm{R}-\mathrm{C}--\mathrm{C}-\mathrm{S}-\mathrm{S}-\mathrm{S}-\mathrm{S}-\mathrm{S}-\mathrm{S}-\mathrm{S}-\mathrm{S}-\mathrm{S}-\mathrm{S}-\mathrm{S}$ $-\mathrm{C}-\mathrm{S}-\mathrm{C} \mathrm{s}-\ldots-\mathrm{s}-\ldots-\mathrm{s}-\ldots-\ldots-\mathrm{s}$ $-\mathrm{C}-\mathrm{C}-\mathrm{C} \mathrm{S}-\ldots-\mathrm{S} \mathrm{R}--\mathrm{S}-\ldots-\ldots-\ldots$ $-\mathrm{C}-\mathrm{S}-\mathrm{S} \mathrm{S}-\ldots-\mathrm{C} \mathrm{R}-\mathrm{S}-\ldots-\ldots-\ldots$ $-\mathrm{C}-\mathrm{S}-\mathrm{S} \mathrm{S}-\ldots \mathrm{S} \mathrm{R}-\mathrm{C}-\ldots-\ldots$

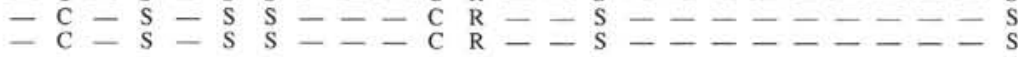


Table 7 (continued).

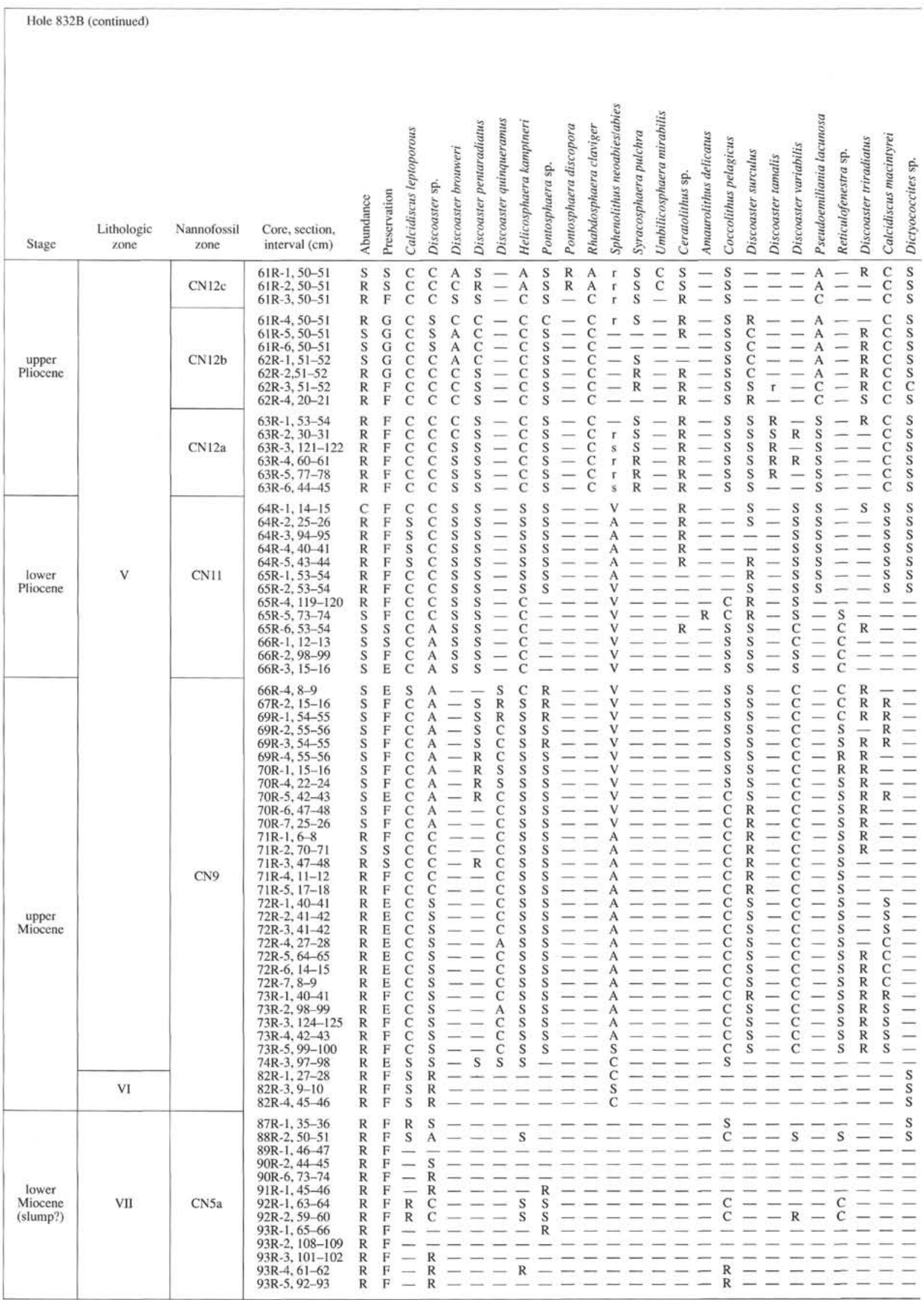


Table 7 (continued).

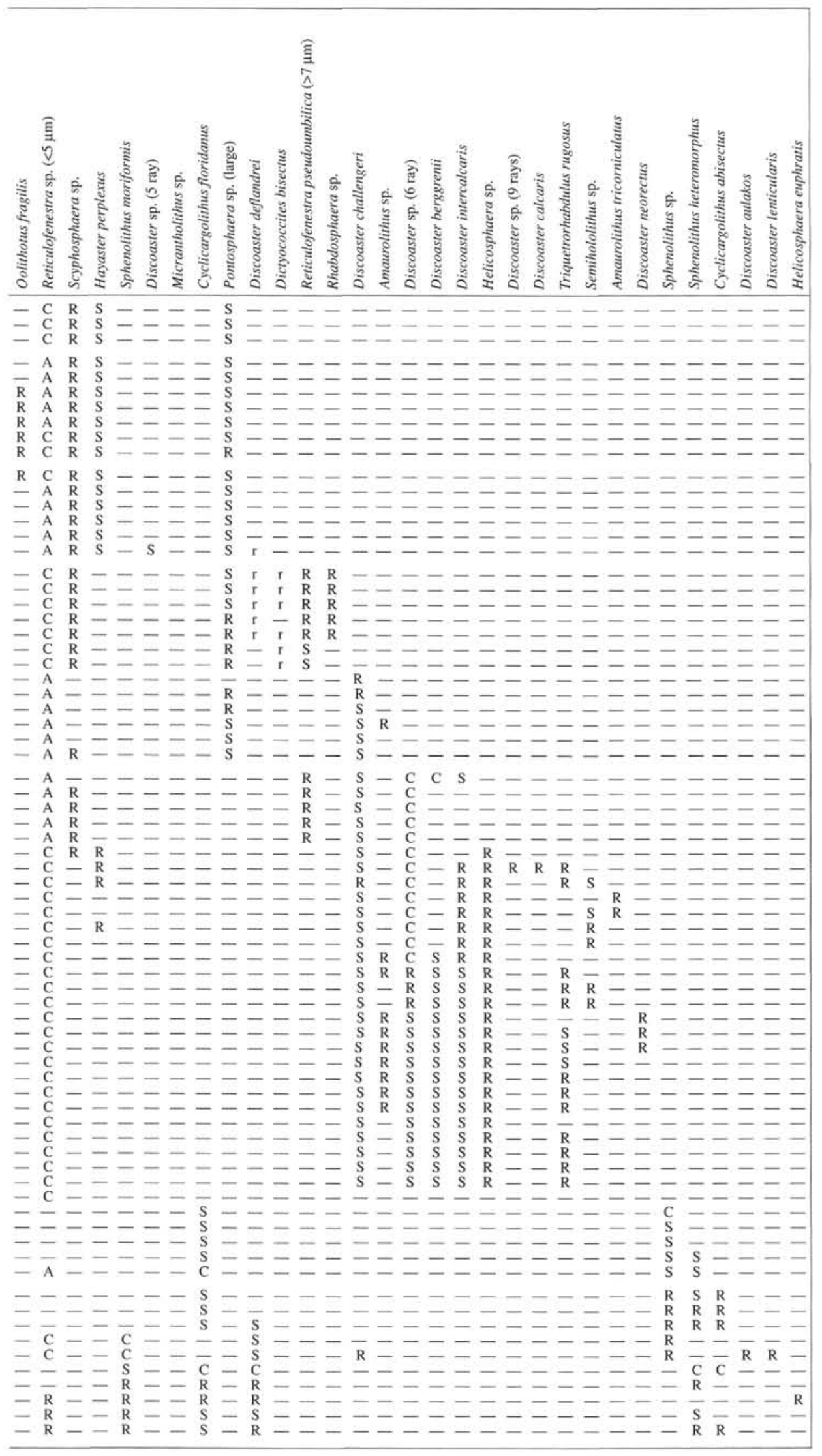


A

\begin{tabular}{|c|c|c|c|c|c|}
\hline \multirow{2}{*}{ Age } & \multicolumn{2}{|c|}{ Zone } & \multirow{2}{*}{$\begin{array}{l}\text { Core, section, } \\
\text { interval }(\mathrm{cm})\end{array}$} & \multirow{2}{*}{$\begin{array}{l}\text { Depth } \\
\text { (mbsf) }\end{array}$} & \multirow{2}{*}{ Datum } \\
\hline & (Okada and Bukry, 1980) & (Martini, 1971) & & & \\
\hline \multirow{17}{*}{$\begin{array}{l}\text { late } \\
\text { Pleistocene }\end{array}$} & \multirow{17}{*}{ CN15 } & \multirow{17}{*}{ NN21 } & $1 \mathrm{H}-1,110-111$ & $1.10-1.12$ & \\
\hline & & & $1 \mathrm{H}-3,114-115$ & $4.14-4.15$ & \\
\hline & & & $2 \mathrm{H}-1,92-93$ & $6.82-6.83$ & \\
\hline & & & $2 \mathrm{H}-4,72-73$ & $11.12-11.13$ & \\
\hline & & & $2 \mathrm{H}-6,34-35$ & $13.74-13.75$ & \\
\hline & & & $3 \mathrm{H}-1,47-48$ & $15.87-15.88$ & \\
\hline & & & $4 \mathrm{H}-1,14-16$ & $18.64-18.65$ & \\
\hline & & & $4 \mathrm{H}-3,60-61$ & 22.10-22.11 & \\
\hline & & & $4 \mathrm{H}-5,44-45$ & 24.94-24.95 & \\
\hline & & & $4 \mathrm{H}-7,4-5$ & 27.54-27.55 & \\
\hline & & & $5 \mathrm{H}-1,70-71$ & $28.70-28.71$ & \\
\hline & & & $6 \mathrm{H}-1,51-52$ & $38.01-38.02$ & \\
\hline & & & $6 \mathrm{H}-3,54-55$ & $41.04-41.05$ & \\
\hline & & & $6 \mathrm{H}-4,52-53$ & $42.52-42.53$ & \\
\hline & & & $7 \mathrm{H}-2,93-94$ & $49.43-49.44$ & \\
\hline & & & $7 \mathrm{H}-4,92-93$ & $52.42-52.43$ & FAD E. huxleyi \\
\hline & & & $7 \mathrm{H}-6,56-57$ & $55.06-55.07$ & $0.28 \mathrm{Ma}$ \\
\hline \multirow{22}{*}{$\begin{array}{l}\text { middle } \\
\text { Pleistocene }\end{array}$} & \multirow{22}{*}{ CN14b } & \multirow{22}{*}{ NN20 } & $8 \mathrm{H}-1,70-71$ & $57.20-57.21$ & \multirow{22}{*}{$\begin{array}{l}\text { Disturbed; } \\
\text { flow-in }\end{array}$} \\
\hline & & & $8 \mathrm{H}-3,68-69$ & 60.18-60.19 & \\
\hline & & & $9 \mathrm{H}-1,58-59$ & $63.58-63.59$ & \\
\hline & & & $9 \mathrm{H}-3,59-60$ & $66.59-66.60$ & \\
\hline & & & $9 \mathrm{H}-5,59-60$ & $69.59-69.60$ & \\
\hline & & & $9 \mathrm{H}-7,59-60$ & $72.49-72.50$ & \\
\hline & & & $10 \mathrm{H}-1,79-80$ & 73.29-73.30 & \\
\hline & & & $10 \mathrm{H}-3,80-81$ & $76.30-76.31$ & \\
\hline & & & $10 \mathrm{H}-5,79-80$ & 79.29-79.30 & \\
\hline & & & $10 \mathrm{H}-7,30-31$ & $81.80-81.81$ & \\
\hline & & & $11 \mathrm{H}-1,78-79$ & 82.78-82.79 & \\
\hline & & & $11 \mathrm{H}-3,55-56$ & $85.55-85.56$ & \\
\hline & & & $11 \mathrm{H}-5,55-56$ & $88.55-88.56$ & \\
\hline & & & $11 \mathrm{H}-7,27-28$ & $91.27-91.28$ & \\
\hline & & & $12 \mathrm{H}-4,100-101$ & $97.00-97.01$ & \\
\hline & & & $16 \mathrm{H}-1,85-86$ & $116.85-116.86$ & \\
\hline & & & $17 \mathrm{H}-1,59-60$ & $126.09-126.10$ & \\
\hline & & & $17 \mathrm{H}-3,59-60$ & $129.09-129.10$ & \\
\hline & & & $18 \mathrm{H}-1,65-66$ & $132.15-132.16$ & \\
\hline & & & $18 \mathrm{H}-3,65-66$ & $135.15-135.16$ & \\
\hline & & & $18 \mathrm{H}-5,37-38$ & $137.87-137.88$ & \\
\hline & & & $\begin{array}{l}19 \mathrm{H}-1,59-60 \\
20 \mathrm{H}-1,40-41\end{array}$ & $\begin{array}{l}141.59-141.60 \\
145.41-141.42\end{array}$ & \\
\hline
\end{tabular}

Figure 11. Nannofossil biostratigraphic summary. A. Hole 832A. B. Hole 832B.

$45-46 \mathrm{~cm}$, requires a younger zonal designation of at least CN14a. This discrepancy in ages can be explained by slumping in which sediments of the lowermost Pleistocene or latest Pliocene (CN13) are slumped into in-situ lower Pleistocene sediments containing $G$. oceanica $(\mathrm{CN} 14 \mathrm{a})$. This is confirmed by results obtained from sedimentology and structural geology (Collot, Greene, Stokking, et al., 1992).

Gephyrocapsa oceanica remains prevalent through Sample 134832B-53R-7, 52-53 cm, the last sample above a $45-\mathrm{m}$ interval of basaltic breccia-volcanic sandstone devoid of nannofossils. All in-situ samples above this interval are younger than $1.45 \mathrm{Ma}$ because $C$. macintyre is absent, but older than $0.46 \mathrm{Ma}$ because of abundant $P$. lacunosa. The samples below the basaltic breccia-volcanic sandstone lack G. oceanica and discoasters, but contain abundant to common C. macintyrei. This assemblage indicates that samples just below the basaltic breccia-volcanic sandstone are lowermost Pleistocene to uppermost Pliocene (Zone CN13), older than 1.58 Ma (FAD G. oceanica) but younger than $1.89 \mathrm{Ma}(\mathrm{LAD} D$. brouweri). This interpretation suggests that a hiatus ranging from 0.13 (LAD C. macintyrei to FAD G. oceanica) to 1.43 m.y. (LAD P. lacunosa to LAD D. brouweri) exists across the interval occupied by the basaltic breccia-volcanic sandstone. Seismic reflection profiles support this interpretation by indicating an unconformity at approximately $700 \mathrm{mbsf}$, which corresponds to the basaltic breccia-volcanic sandstone interval (Fisher et al., this volume; Pelletier et al., this volume; Collot, Greene, Stokking, et al., 1992). In addition to $C$. macintyrei, the accompanying assemblage in Samples 134-832B-59R-1, 40-41 cm, through -59R-3, 40-41 cm, includes $P$. lacunosa, H. kamptneri, C. leptoporus, R. claviger, Scapholithus fossilis, Umbilicosphaera mirabilis, and Syracosphaera pulchra.

\section{Pliocene}

Samples 134-832B-59R-4, 40-41 cm, through -60R-5, 51-52 cm, are uppermost Pliocene. Rare to common occurrences of both $D$. brouweri and Discoaster triradiatus in the absence of gephyrocapsids larger than $4 \mu \mathrm{m}$ indicate Zone CN12d. Calcidiscus macintyrei, H. kamptneri, C. leptoporus, and small reticulofenestrids $(<5 \mu \mathrm{m})$ are also present. Common D. triradiatus signifies the top of the range for $D$. brouweri and, therefore, proximity to the Pliocene/Pleistocene boundary (Takayama, 1970; Backman and Shackleton, 1983; Backman and Pestiaux, 1987; Rio et al., 1990). There is no evidence for reworking in these samples.

In Samples 134-832B-61R-1, 50-51 cm, through -61R-3, 50-51 $\mathrm{cm}, D$. pentaradiatus becomes an important part of the assemblage and indicates Zone 12c. Discoaster pentaradiatus is present in several cores just above this placement for its $\mathrm{LAD}$; however, the abundances are too low to be considered biostratigraphically significant ( $<1$ specimen per 1000 fields of view).

Samples 134-832B-61R-4, 50-51 cm, through -62R-4, 20-21 cm, are upper Pliocene and correspond to Zone $\mathrm{CN} 12 \mathrm{~b}$. Discoaster surculus was found in varying abundances throughout this interval and is accompanied by the upper Pliocene assemblage described earlier. Discoaster tamalis occurs sporadically and in very rare abundances 


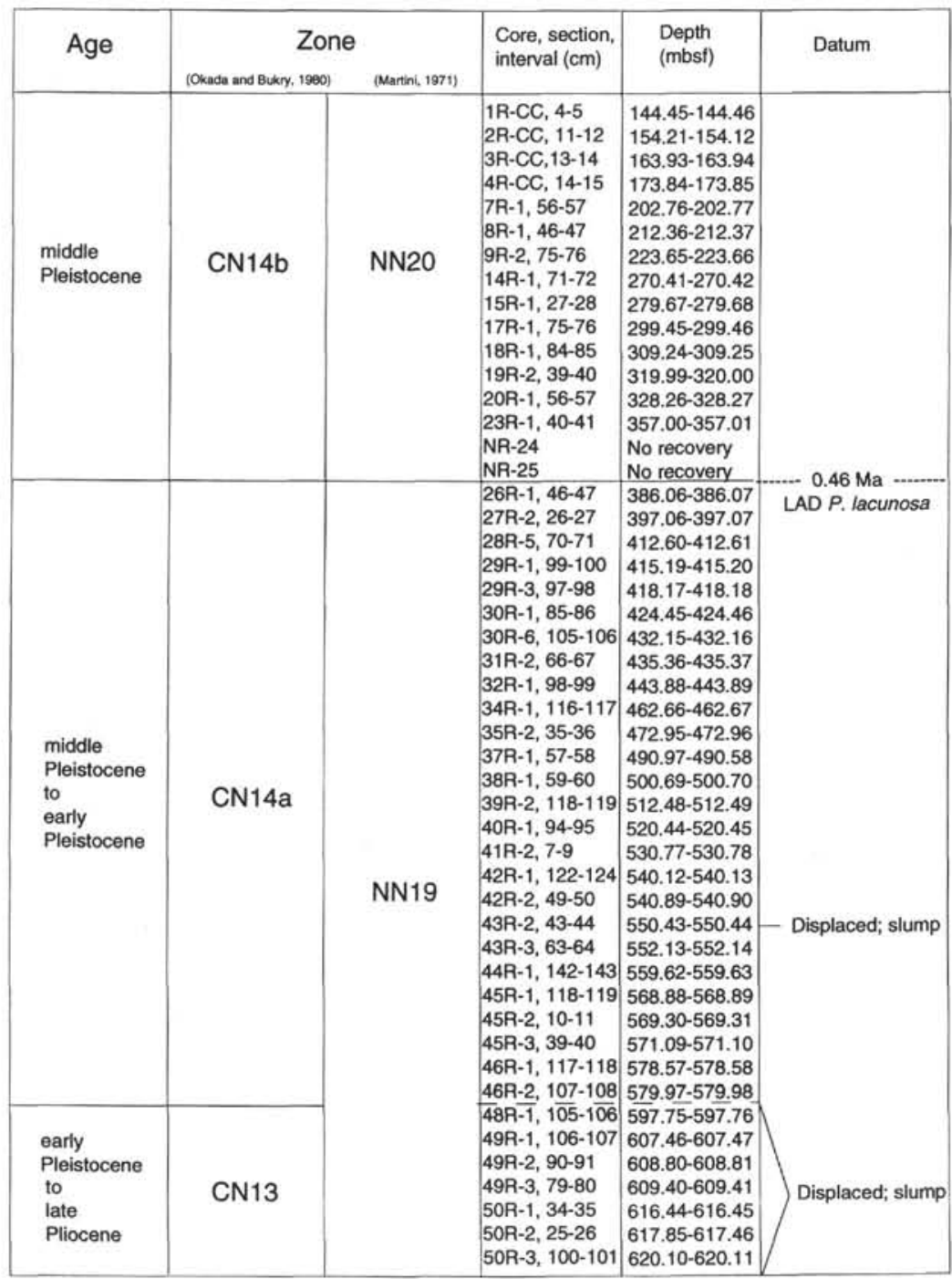

Figure 11 (continued).

in the lowermost sections of this interval. These specimens of $D$. tamalis are too few to be considered biostratigraphically significant.

In Sample 134-832B-63R-1, 53-54 cm, D. tamalis increases in abundance from rare to sparse. This increase is interpreted as the top of its true stratigraphic range, which places the sample in upper Pliocene Zone CN12a. Despite the absence of $D$. tamalis in several samples, Zone CN12a continues down to where appreciable numbers of $S$. abies/S. neoabies suggest that these sediments are within lower Pliocene Zone CN11. The conventional marker delineating the top of Zone CN11, Reticulofenestra pseudoumbilica, occurs only sporadically in rare numbers below Sample 134-832B-63R-6, 44-45 cm. Also present in this zone, which extends down to Sample 134-832B-66R-3, 15-16 $\mathrm{cm}$, are small reticulofenestrids $(<5 \mu \mathrm{m}), D$. brouweri, $H$. kamptneri, C. leptoporus, sparse $P$. lacunosa, D. variabilis, D. pentaradiatus, and D. surculus. There is no evidence of reworking in these samples; however, abundances are low and the preservation is only fair.

\section{Miocene}

Samples with nannofossil assemblages indicative of the upper Miocene were found in Samples 134-832B-66R-4, 8-9 cm, through $-84 \mathrm{R}-1,116-117 \mathrm{~cm}$. The presence of Discoaster quinqueramus and
Discoaster berggrenii in association with D. brouweri, H. kamptneri, D. variabilis, C. macintyrei, Dictyococcites sp. $(<5 \mu \mathrm{m})$, and Reticulofenestra $s p .(<5 \mu \mathrm{m})$ suggests that these samples are within Zone $\mathrm{CN} 9$. There is no evidence for reworking, and preservation is moderate. Although nannofossil abundances fluctuated as high as common, many samples were rare to barren.

\section{Middle Miocene}

Between Samples 134-832B-84R-CC (shipboard sample, Collot, Greene, Stokking, et al., 1992) and -92R-2, 59-60 cm, age determinations are problematic primarily because of the paucity of nannofossils. Most samples from this interval contain rare Sphenolithus heteromorphus and C. floridanus, which suggests deposition in the early or middle Miocene (CN4 or CN3); however, Samples 134-832B-92R-2, $59-60 \mathrm{~cm}$, and $-88 \mathrm{R}-2,50-51 \mathrm{~cm}$, which contain the highest quantities of nannofossils, also contain Discoaster signus, Discoaster moorei, and Discoaster aulakos in the absence of $S$. heteromorphus, indicating a younger origin for these samples. Although the samples lacking $S$. heteromorphus are fewer in number, sample quality is superior and an age of middle Miocene (CN5a) is, therefore, interpreted for the entire interval. According to this interpretation all of the 


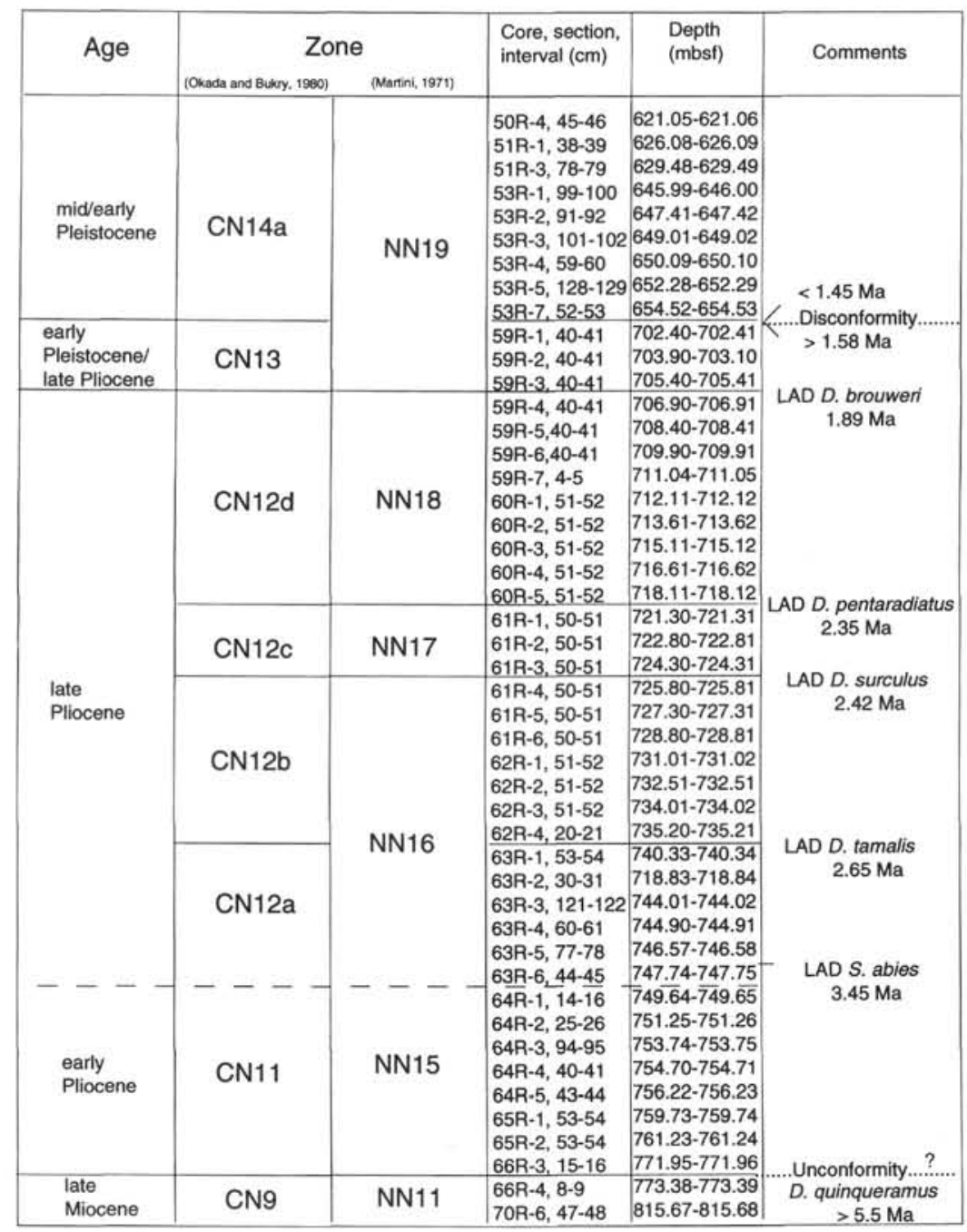

Figure 11 (continued),

specimens of $S$. heteromorphus are considered reworked from the next oldest zone (CN4).

A comparison of the sedimentologic, seismic stratigraphic, and structural geologic analyses corresponding to the aforementioned middle Miocene (CN5a) interval indicates the existence of slump structures (Goud, this volume; Fisher et al., this volume; Pelletier et al., this volume; Collot, Greene, Stokking, et al., 1992), which suggests that Samples 134-832B-84R-CC through -92R-2, 59-60 cm, (CN5a) are actually displaced. However, neither this study nor that of the foraminiferal specialist (Perembo, this volume) indicates ages younger than middle Miocene for this interval.

Potassium argon dating on a clast taken several cores below the last fossiliferous sample yielded an age of latest Miocene (Rex, this volume). This maximum age of latest Miocene is consistent with seismic stratigraphic interpretations (Fisher et al., this volume), but contradicts the nannofossil interpretation of $\mathrm{CN} 5 \mathrm{a}$ for sediments uphole. The evidence for slumping in the sediments dated by nannofossils as Zone $\mathrm{CN} 5 \mathrm{a}$, coupled with the $\mathrm{K}$-Ar-dated clast from downhole indicates that the interval below Sample 134-832B-84R-CC is most likely a large slump composed of middle and lower Miocene sediments. Despite the constraints placed on the biostratigraphy by sedimentology and isotopic dating, there is no floral or faunal evidence to indicate that these sediments are younger than middle/early Miocene in age. For this reason, the nannofossil range charts in this interval reflect a middle/early Miocene age.

\section{Basin Flank}

\section{Site 833}

Samples recovered from Holes $833 \mathrm{~A}$ and $833 \mathrm{~B}$ are generally of low quality. Reworking and dilution of the nannofossils by volcaniclastic sediments are more severe at this site than at any other Leg 134 site. Barren intervals associated with volcanic intrusives also disrupt the biostratigraphic record at this site. Despite these problems an apparently continuous stratigraphic section is indicated by nannofossil ages ranging from late Pleistocene (CN15) to early Pliocene (CN11) (Fig. 12 and Table 8). However, unlike the other previously mentioned sites, the presence of the marker species is commonly erratic, resulting in the subjective placement of most zonal boundaries. The nannofossil record is particularly ambiguous between Cores $833 \mathrm{~B}-17 \mathrm{R}$ and $-55 \mathrm{R}$, where abundance and/or preservation is diminished.

Samples 134-833A-1H-1, 79-80 cm, through -4H-3, 54-55 cm, contain the same uppermost Pleistocene assemblage described for the Emiliania huxleyi Zone (CN15) at previous sites. Neogene specimens Discoaster brouweri, Discoaster pentaradiatus, Sphenolithus abies/ 


\begin{tabular}{|c|c|c|c|c|c|}
\hline \multirow[t]{2}{*}{ Age } & \multicolumn{2}{|c|}{ Zone } & \multirow[t]{2}{*}{$\begin{array}{l}\text { Core, section, } \\
\text { interval }(\mathrm{cm})\end{array}$} & \multirow[t]{2}{*}{$\begin{array}{l}\text { Depth } \\
\text { (mbsf) }\end{array}$} & \multirow[t]{2}{*}{ Datum } \\
\hline & (Okada and Bukry, 1980) & (Martini, 1971) & & & \\
\hline $\begin{array}{l}\text { late } \\
\text { Pleistocene }\end{array}$ & CN 15 & NN 21 & $\begin{array}{l}1 \mathrm{H}-1,79-80 \\
2 \mathrm{H}-2,116-117 \\
3 \mathrm{H}-3,126-127 \\
4 \mathrm{H}-3,54-55\end{array}$ & $\begin{array}{l}0.79-0.80 \\
12.16-12.17 \\
23.26-23.27 \\
32.04-32.05 \\
\end{array}$ & $\ldots 0.28 \mathrm{Ma}$ \\
\hline $\begin{array}{l}\text { middle } \\
\text { Pleistocene }\end{array}$ & CN14b & NN20 & $\begin{array}{l}5 \mathrm{H}-3,114-115 \\
6 \mathrm{H}-1,120-121 \\
7 \mathrm{H}-2,132-133 \\
8 \mathrm{H}-2,95-96 \\
10 \mathrm{H}-1,20-21 \\
11 \mathrm{H}-1,110-111 \\
12 \mathrm{H}-1,43-44 \\
13 \mathrm{H}-2,2-3 \\
15 \mathrm{X}-\mathrm{CC} \\
16 \mathrm{X}-2,43-44 \\
17 \mathrm{X}-\mathrm{CC}, 14-15 \\
18 \mathrm{X}-\mathrm{CC}, 17-18 \\
21 \mathrm{X}-2,115-116 \\
23 \mathrm{X}-1,49-50 \\
24 \mathrm{X}-1,85-86 \\
25 \mathrm{X}-\mathrm{CC}, 28-29 \\
26 \mathrm{X}-1,22-23\end{array}$ & \begin{tabular}{|l|}
$36.74-36.75$ \\
$40.40-40.41$ \\
$48.02-48.03$ \\
$56.45-56.46$ \\
$63.10-63.11$ \\
$70.80-70.81$ \\
$76.43-76.44$ \\
$79.52-79.53$ \\
$93.69-93.70$ \\
$95.63-96.64$ \\
$112.71-112.72$ \\
$122.42-122.43$ \\
$144.65-144.66$ \\
$161.79-161.80$ \\
$171.75-171.76$ \\
$190.02-190.03$ \\
$190.52-190.53$ \\
\end{tabular} & FAD E. huxleyi \\
\hline
\end{tabular}

Figure 12. Nannofossil biostratigraphic summary. A. Hole 833 A. B. Hole 833 B.

\section{DISCUSSION: TECTONIC AND SEDIMENTOLOGIC IMPLICATIONS OF THE NANNOFOSSIL DATA}

Owing to the variety of ages and lithologies recovered from the seven sites described herein, an explanation of the evidence for changing depositional environments over time and the possible catalysts for such change is necessary. The biostratigraphic data of each site potentially present constraints on either the timing of the collision of the DEZ with the arc or the origin of the accreted sediments now located in the modern forearc. Some of the data, such as from Hole 829A, are subject to varying interpretations as to the mechanisms that resulted in the complex stratigraphic relationships discovered during drilling. Discussion of the evidence supporting the various interpretations of the Leg 134 data has the ultimate goal of forming a logical model showing how each site is related to the regional geologic history of subduction, accretion and uplift of the arc.

\section{Downwarping of the North Aoba Basin}

The primary objective of Site 832 was to determine the age of the major unconformity located in the NAB. Seismic profiles (Greene and Johnson, 1988; Fisher et al., 1988) detect a prominent basin-wide reflector at approximately 700 mbsf that is believed to be an unconformity that resulted from the downwarping of the NAB in response to the collision of the NDR with the forearc (Chung and Kanamori, 1978; Collot et al., 1985).

Nannofossil analyses from Hole 832B indicate that a hiatus spanning between 0.13 and 1.43 m.y. occurs between 654 and 702 mbsf. Unfortunately, the sediment recovered from this interval is a volcanic sand devoid of nannofossils; however, the samples above and below the barren interval are of different ages. The samples above the volcanic breccia are younger than $1.45 \mathrm{Ma}$, as indicated by the absence of Calcidiscus macintyrei, whereas the samples below the sand lack Gephyrocapsa oceanica and discoasters, which indicates that they are between 1.58 and $1.89 \mathrm{Ma}$ within nannofossil Zone CN13. These data suggest that the basin-wide unconformity discernable from seismic profiles is of latest Pliocene age.

The compositional change from pelagic to arc-derived volcaniclastic and terrigenous clastic sediment evident in the cores of Site 828 , occurred in the early to middle Pleistocene (Zone CN14a). This compositional change indicates the time during which the area of the NDR that was drilled during Leg 134 first began to interact with the forearc. The initial collision of the NDR with the New Hebrides
Island Arc likely occurred earlier than the Pleistocene at Malakula Island (Collot et al., 1985). Collectively the biostratigraphic interpretations from Sites 832 and 828 support the theory of a latest Pliocene NDR/arc collision that resulted in both significant sedimentological changes on the NDR and downwarping of the NAB.

\section{Origin of Accreted Sediments}

Similarities in the age and composition of chalk found in both the forearc at Site 829 and on the NDR at Site 828 strongly suggest that some sediments were probably scraped from the downgoing plate and accreted onto the overriding plate in the forearc adjacent to Espiritu Santo Island. Whether the accreted material at Site 829 originated solely from the subducting bathymetric high or possibly from the surrounding abyssal plain is uncertain. Paleontologic and lithologic data acquired from Sites 830 and 831 (forearc and guyot) are inconclusive as to the presence of accreted material in the forearc between Espiritu Santo and Malakula islands.

Pleistocene and younger volcanic muds on the trench slope and the NDR are similar in composition. This makes the recognition of scraped ridge material of Pleistocene age difficult. Conversely, prePleistocene sediments located in the modern forearc probably originated elsewhere, and these sediments are useful to compare with sediments located both below the unconformity at approximately 62 mbsf in Hole 828A and from DSDP Site 286 located approximately $130 \mathrm{~km}$ to the south of Site 828 .

Owing to the absence of available clastic sediment sources and its elevation of about $3 \mathrm{~km}$ above the surrounding abyssal plain (4500$5000 \mathrm{~m}$ below sea level), the NDR should have experienced only pelagic sedimentation prior to collision with the New Hebrides Island Arc. Likewise, the broader DEZ should have experienced little input of nonpelagic sediments except for those sediments originating from the more elevated NDR and the SDC. The sediments on the deeper seafloor adjacent to the DEZ would be expected to contain materials transported from the neighboring bathymetric highs. Because the sediment cover on the abyssal plain northeast of the DEZ has been either subducted or incorporated into the forearc as offscraped material, the composition and age of this missing sediment must be derived from other nearby geologic sections.

Sediments recovered from DSDP Site 286 provide the best source of data from which to assess the probable composition of subducted abyssal plain sediments at the time the allochthonous pelagic deposits that are in the forearc were originally deposited. Sediments consid- 


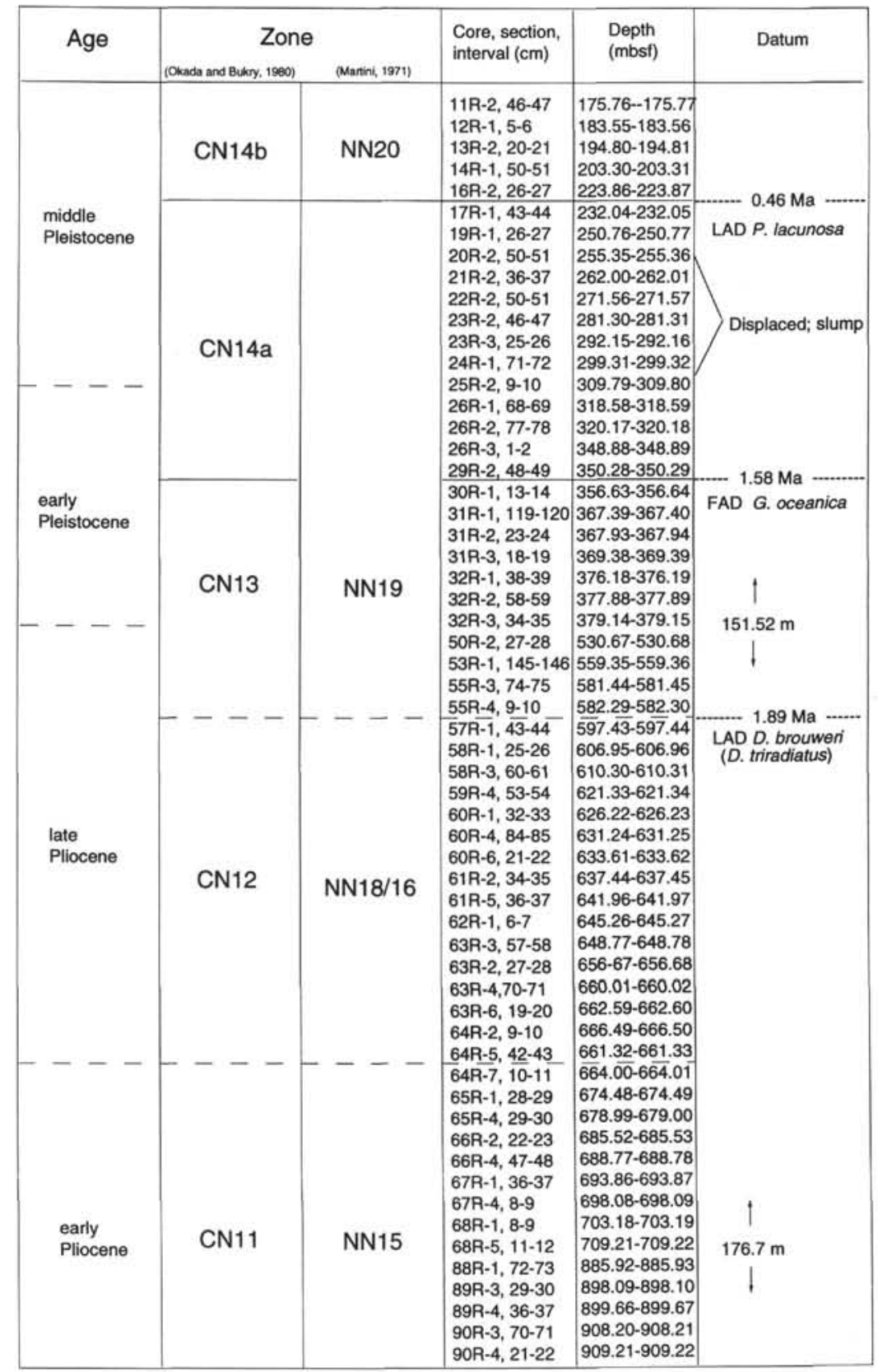

Figure 12 (continued).

ered to be upper and lower Pliocene (Shafik, 1975) at Site 286 contain significant quantities of volcanic glass, reworked nannofossils, and abyssal clays. In contrast, sediments below the uppermost disconformity at Site 828 , which are dated as early Pliocene or older, are either pelagic microfossil-rich carbonates or clayey microfossil-bearing carbonates that contain neither reworked microfossils nor significant quantities of volcanic debris (Collot, Greene, Stokking, et al., 1992). The dissimilarity between the sediments at Sites 286 and 828 suggests that if Site 286 is an accurate lithologic proxy for Pliocene sediments located originally between the DEZ and the trench at the latitude of Espiritu Santo Island, there is no evidence for the accretion of abyssal sediments based on the sediments recovered from the forearc at Hole $829 \mathrm{~A}$. Because Hole $829 \mathrm{~A}$ is at the toe of the accretionary complex where thrusting is young (latest Pleistocene), the possibility remains that an earlier episode of accretion involving Pliocene abyssal sediments may be present arcward of Hole 829A.

Only two intervals of Pliocene chalk were recovered from Hole $829 \mathrm{~A}$. One of these intervals appears to be from a 30 -cm-thick layer, whereas the other is approximated from Formation MicroScanner images to be $7 \mathrm{~m}$ thick (Collot, Greene, Stokking, et al., 1992). Because these layers are thin and were recovered with Pleistocene mixed sediments, they probably were deposited as a trench fill and therefore were not scrapped from the downgoing plate as coherent units (Reid, this volume).

It is uncertain whether these Pliocene components of the trench fill originated from the overriding or subducting plate. The NDR is probably not the source of the displaced Pliocene material because the Pliocene sediments from Site 828 are "soupy" foraminiferal oozes 
that could not be transported as coherent clasts without significant compaction and dewatering. In contrast, Pliocene material comparable to that recovered from Hole 829A is exposed in the forearc (Collot et al., 1992) and from the Tawoli Formation on neighboring Espiritu Santo Island (Macfarlane et al., 1988).

Calcilutites of the Tawoli Formation that contain Pliocene microfossils (D. Taylor, unpubl. data, 1977; Paltech, Pty. Ltd., unpubl. data, 1979) are uplifted and exposed on the island of Espiritu Santo and may underlie some of the upper forearc. These rocks were originally formed during a transgression as sediments deposited in small fault-bounded basins in and around present-day Espiritu Santo Island (Macfarlane et al., 1988; Greene et al., 1988; Figs. 13A and B). Data from the Nautile dives of the 1989 SUBPSO cruise did not encounter Pliocene chalk units exposed in the upper forearc (dive 1) adjacent to Espiritu Santo Island (Collot et al., 1992), but some lower Pliocene material was recovered from the dives conducted lower on the forearc slope (Collot et al., 1992; Collot and Fisher, 1992; Greene et al., 1992). Conflicting age interpretations between nannofossils and foraminifers (Collot et al., 1992) suggest that the Pliocene material recovered from the dives is probably a component of Pleistocene mixed sedimentary trench-fill deposits. Collectively, the data from both the 1989 SUBPSO Cruise and Leg 134 suggest that the initial source of Pliocene chalk, recovered as clasts in Hole 829A and as mixed-sediment trench-fill in the Nautile dives, is the Tawoli calcilutite exposed in the upper forearc adjacent to Espiritu Santo Island.

As with the Pliocene deposits, the origin of the middle Miocene sediments recovered from Hole $829 \mathrm{~A}$ is ambiguous. Hole $829 \mathrm{~A}$ was the only site with chalk from nannofossil Zone CN4, which is characterized by the distinctive Sphenolithus heteromorphus. At Hole $828 \mathrm{~A}$, all of the Miocene is missing. Similarly, the middle Miocene at Site 286 is represented by either an unconformity or strata barren of calcareous nannofossils owing to deposition below the carbonate compensation depth (CCD) (Shipboard Scientific Party, 1975). If sediments on the downgoing plate supplied the accreted CN4 material, then their absence at Site 828 results from a localized unconformity and middle Miocene sediment should be present elsewhere on the NDR or DEZ.

An alternative explanation is that the lower Miocene (CN4) material was transported as clasts down the forearc slope and incorporated into trench sediments. These sediments could have originated either from the island or submerged rocks between the arc massif and the trench, which were uplifted and eroded upon the initiation of DEZ-arc collision at Espiritu Santo Island. Supporting evidence for an arc origin comes from the presence of Sphenolithus heteromorphus, a reworked species found commonly throughout the Pleistocene volcanic siltstones recovered from both the forearc sites and reference Site 828 . The abundance of reworked $S$. heteromorphus in Pleistocene strata indicates that a large mass of lower Miocene (CN4) strata was eroded during the Pleistocene either within the forearc or on the nearby island of Espiritu Santo. Geological reports from the island of Espiritu Santo provide foraminiferal age interpretations for the Pua, Peteao, and Pelapa Formations (Macfarlane et al., 1988). Foraminiferal interpretations constrain the age of these formations to the middle Miocene Zones N8-N10, which coincide with nannofossil Zone CN4. Although the lithologies and inferred environments of deposition are different from those of the Site 829 chalks, lateral facies changes distal to the early arc could account for these differences (Figs. 14A and B).

The origin of the lower Miocene or upper Oligocene (CN1/CP19) rocks recovered from Hole $829 \mathrm{~A}$ is the most difficult to determine because they occur extensively throughout Hole 829A but cannot be clearly correlated with rocks from either Espiritu Santo Island or the NDR. Citing the similarity in age and composition between middle Oligocene to lower Miocene sediments recovered along dive 4 of the Nautile with Eocene to late Oligocene sediments from DSDP Site 286, Collot et al. (1992) suggested that sediments of this age were likely scraped from the downgoing plate. Middle Oligocene age (NP23) sediments recovered during dive 4 that locally contain reworked Eocene taxa (Collot et al., 1992; C. Müller, unpubl. data, 1989), are similar to sediments recovered from both DSDP Site 286 and ODP Site 828. However, other samples along the same dive 4 transect at the toe of the slope have been interpreted as mixed sedimentary rocks. Conflicting age interpretations between foraminifers (Pleistocene) and nannofossils (Miocene or Oligocene) for all of the pre-Pliocene samples from dive 4 suggest that the rocks recovered from the toe of the slope show some degree of sediment mixing and are, therefore, probably Pleistocene trench-fill deposits that were then accreted. The sediments from dive 4 are apparently most similar to sediments recovered from Hole $829 \mathrm{~A}$, which in some samples contained minute quantities of Pleistocene taxa interspersed with the Oligocene or Miocene taxa. As a component of the trench fill, these displaced lower Miocene or upper Oligocene clasts and olistoliths could have come from either the overriding or downgoing plate.

There are no sediments of Miocene or latest Oligocene age at Site 828 , as this interval is represented by an unconformity. The youngest Paleogene sediments recovered at Site 828 are interpreted as late to early Oligocene Zone CP17/18; however, the presence of sporadic, rare occurrences of a sphenolith resembling S. ciperoensis in some samples from Hole 828A may indicate that upper Oligocene sediments occur on the NDR. It is also possible that the unconformity above this zone is only local, allowing for upper Oligocene or Miocene sediments to be exposed elsewhere on the DEZ.

The oldest rocks exposed on Espiritu Santo Island are upper Oligocene to lower Miocene volcanic breccias with limited exposures of shallow-water limestones of the Ora Formation. The oldest microfossil-bearing strata from the western belt of islands is the middle Miocene Kerewai Formation, which is too young to be the source of the lower Miocene to upper Oligocene clasts from Hole 829A. The Kerewai Formation does, however, contain a reworked shallow-water, benthonic foraminiferal fauna indicative of late Oligocene to early Miocene age. It is possible that the depositional environment for the Oligocene to Miocene chalks recovered at Hole 829A was the openmarine facies distal to the shallow-marine environment that produced the benthonic foraminifers (Figs. 14A and B).

Although clasts of Oligocene and upper Eocene material occur commonly throughout Hole 829A (Appendix C), units of this age are the only pre-Pleistocene sediments that appear to have been clearly thrust into place as coherent packages. The small units of Pliocene and Oligocene to Miocene material discussed earlier can be readily explained as reworked clasts or olistoliths that moved down the steep slope of the forearc and deposited in the trench. Pleistocene material forms the matrix of the olistostromal trench fill that was then accreted. This is an unlikely explanation for the origin of the coherent repeated units of upper Oligocene to Eocene material recovered from the bottom of Hole 829A. Because the Oligocene and Eocene sediments in Hole 829A did not contain mixed lithologies or nannofossil assemblages like most of the younger deposits, these sediments are probably not part of an accreted trench fill. That lower Oligocene and Eocene deposits also appear together in Hole 829A overlying Pleistocene deposits suggests that they were scraped off as coherent units. Additional evidence against the arc as the primary source of these sediments relies on the absence of deep-water facies rocks of this age on the nearby island of Espiritu Santo.

A comparison of the ages inferred for the underlying basement of both plates in this region also suggests that the downgoing plate is the source of the Oligocene and Eocene age sediments from Hole 829A. The age of the underlying basement at nearby Pentecost Island has been dated as early Oligocene based on the age of ophiolites exposed there (Mallick and Neef, 1974). The age of the basement on the downgoing Australia plate near the New Hebrides Island Arc, south of the DEZ, is inferred to be early Eocene based upon magnetic lineations (Weissel et al., 1982). Basement rocks recovered from DSDP Site 286 are dated as middle Eocene (Shipboard Scientific 
Table 8. Nannofossil range charts for Site 833 .

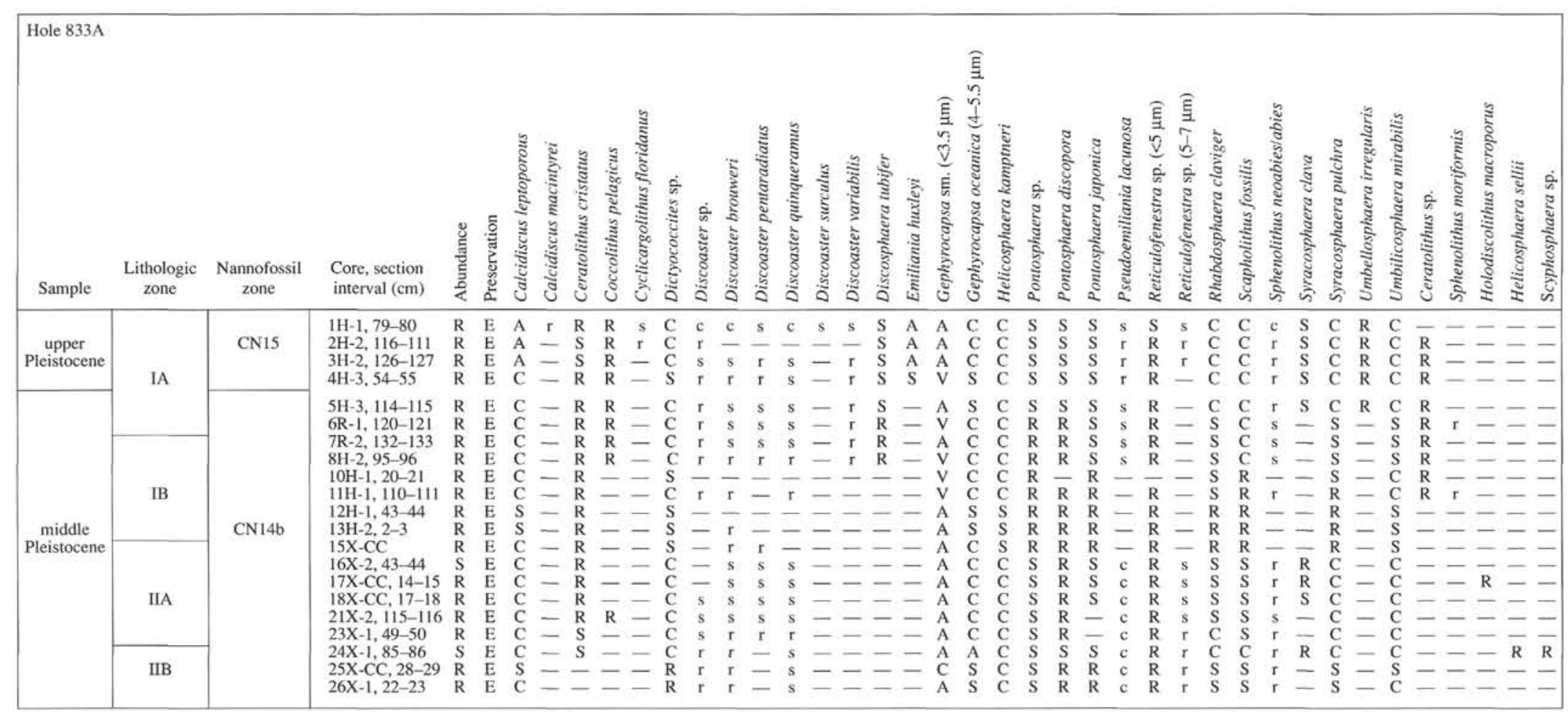


Table 8 (continued).

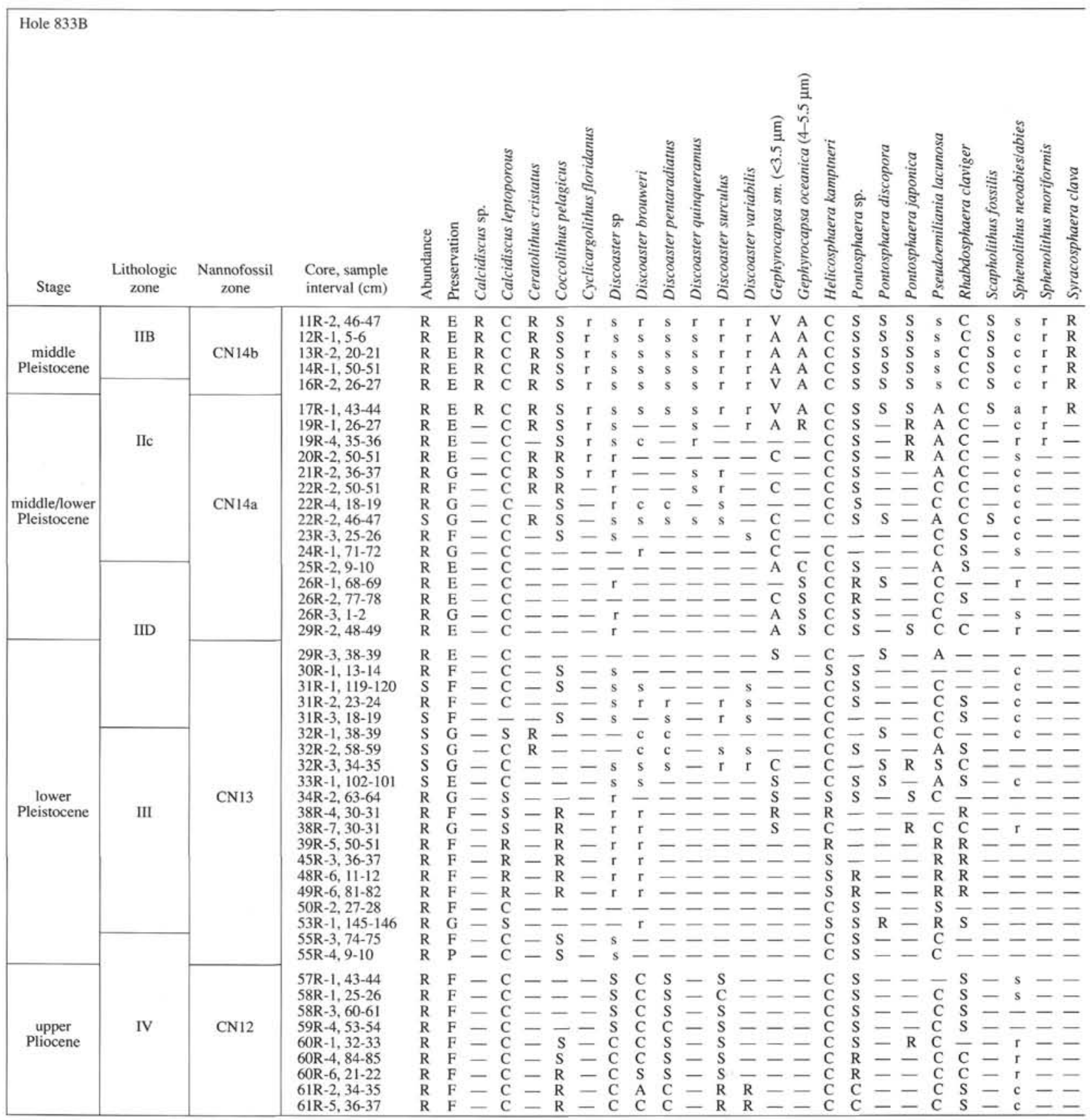

Party, 1975). In addition, a middle Eocene breccia was dredged from the Bougainville Guyot (Collot et al., 1992), as was a Paleogene MORB basalt from the DEZ (Maillet et al., 1983).

The oldest material recovered from the forearc during Leg 134 comprises middle Eocene clasts recovered from Site 827. The age of these clasts predates formation of the overriding plate on which the forearc rests and the clasts almost certainly must have originated from the Australia Plate.

\section{Evidence for Thrusting}

Complications that arise from extensive particle reworking and mass wasting within the Pleistocene interval make the biostratigraphic interpretation of Site 829 difficult. Because of the sedimentological complexity of Site 829 , the nannofossil age interpretations have been carefully integrated with sedimentologic interpretations (Reid et al., this volume). Nevertheless, biostratigraphic evidence for thrust faulting at Site 829 consists of five age reversals in which lower Neogene and Paleogene chalks overlie upper and middle Pleistocene vitric siltstones and two age reversals within Pleistocene strata. This evidence for thrust faulting within the accretionary prism is supported by observations of intense shearing (Meschede and Pelletier, this volume; Collot, Greene, Stokking, et al., 1992).

The shallowest and most prominent of the age reversals occurs at approximately $99 \mathrm{mbsf}$, where lower Miocene to upper Oligocene chalk of Zone CN1/CP19 (Samples 134-829A-8R-CC, 6-7 cm through $-11 \mathrm{R}-\mathrm{CC}, 8-9 \mathrm{~cm}$ ) overlies Pleistocene vitric siltstone of Zones CN15 and CN14 (Samples 134-829A-12R-1, 80-81 cm, through -20R-2, $112-113 \mathrm{~cm}$; Fig. 9). The sharp floral change at this boundary is accompanied by a dramatic lithologic change, apparent on both core 
Table 8 (continued).

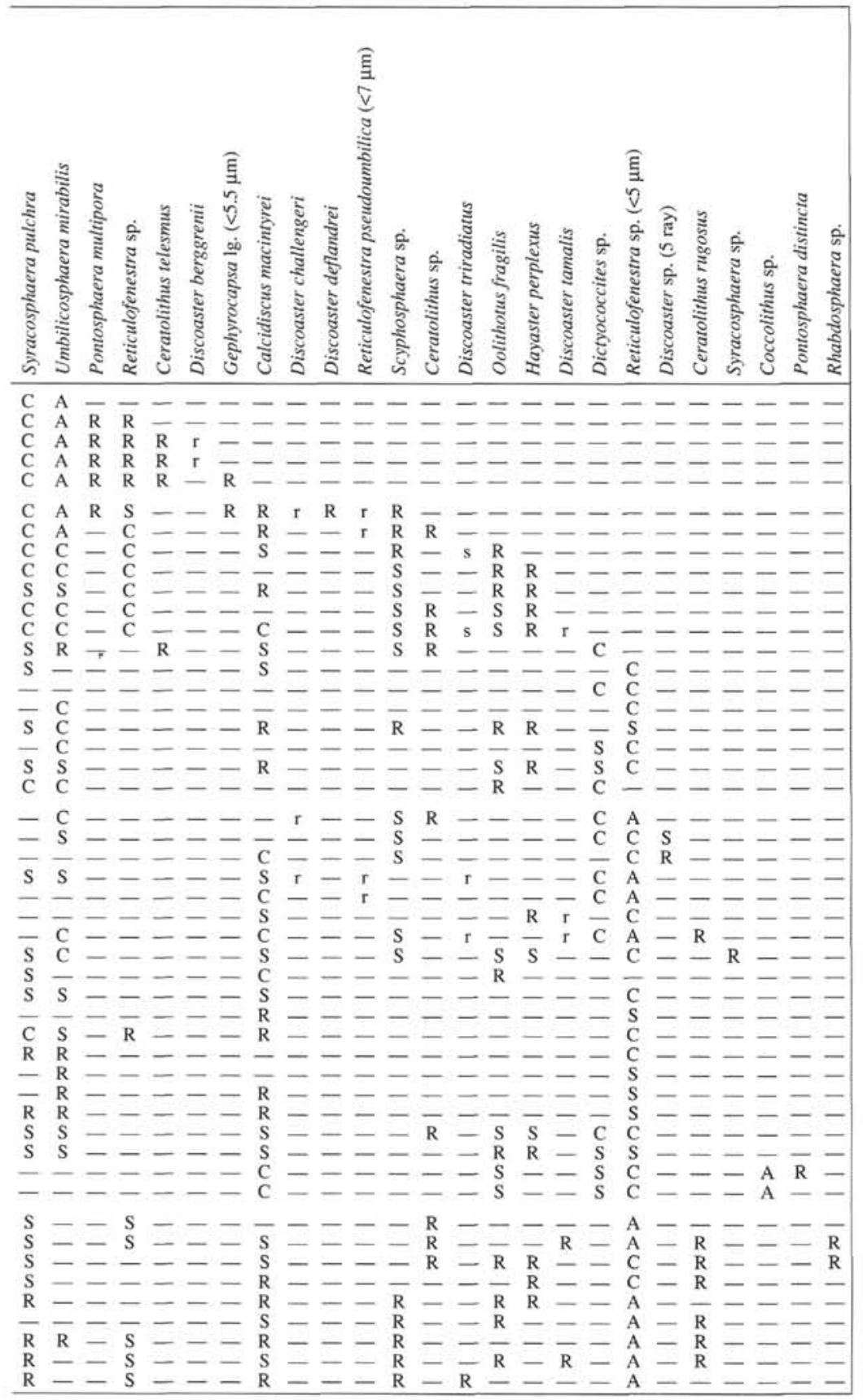

photos and petrophysical logs (Figs. 15 and 16). Despite poor recovery of this interval, the calcium yield on the geochemical log indicates that the chalk unit is continuous throughout the entire interval (Fig. 16). The thickness of this unit as delineated by logging is approximately $45 \mathrm{~m}$.

Because there is no structural evidence to suggest that faulting has occurred in this cored interval, it could be argued that the lower Miocene to upper Oligocene chalk is an olistolith or slump block rather than a thrust package. Considering that the depositional environment is one in which slumping is expected and clasts of this age are prevalent in other Hole 829A units interpreted as trench-fill deposits (Reid et al., this volume; Collot, Greene, Stokking, et al., 1992), a depositional explanation is plausible. The chalk unit is brecciated like other chalks of this age; however no Pleistocene species were encountered in these samples. The contacts between lower Miocene to upper Oligocene chalk and the overlying and underlying Pleistocene deposits are sharp and lack clasts or mixed sediments typical of the other units from Hole $829 \mathrm{~A}$ interpreted as trench fill deposits. Collectively, these data suggest that the chalk unit is probably not an olistolith but may be an isolated slump block within Pleistocene sediments. If displaced into Pleistocene sediments, the lower Miocene or upper Oligocene unit would have no bearing on the interpretation of a thrust fault. In fact, biostratigraphic evidence for an age reversal, and hence a thrust fault, exists irrespective of the presence of the chalk unit because a repeated section of CN15 is encountered beginning at 99 mbsf (Sample 134829A-12R-1, 80-81 cm; Figs. 9 and 17).

The second interval for which biostratigraphic data provide evidence of thrust faulting is from Samples 134-829A-17R-1, 40-41 cm, through -17R-2, 40-41 cm (147.60-149.10 mbsf). Sediment containing Emiliania huxleyi (CN15) underlies sediment belonging to lower 


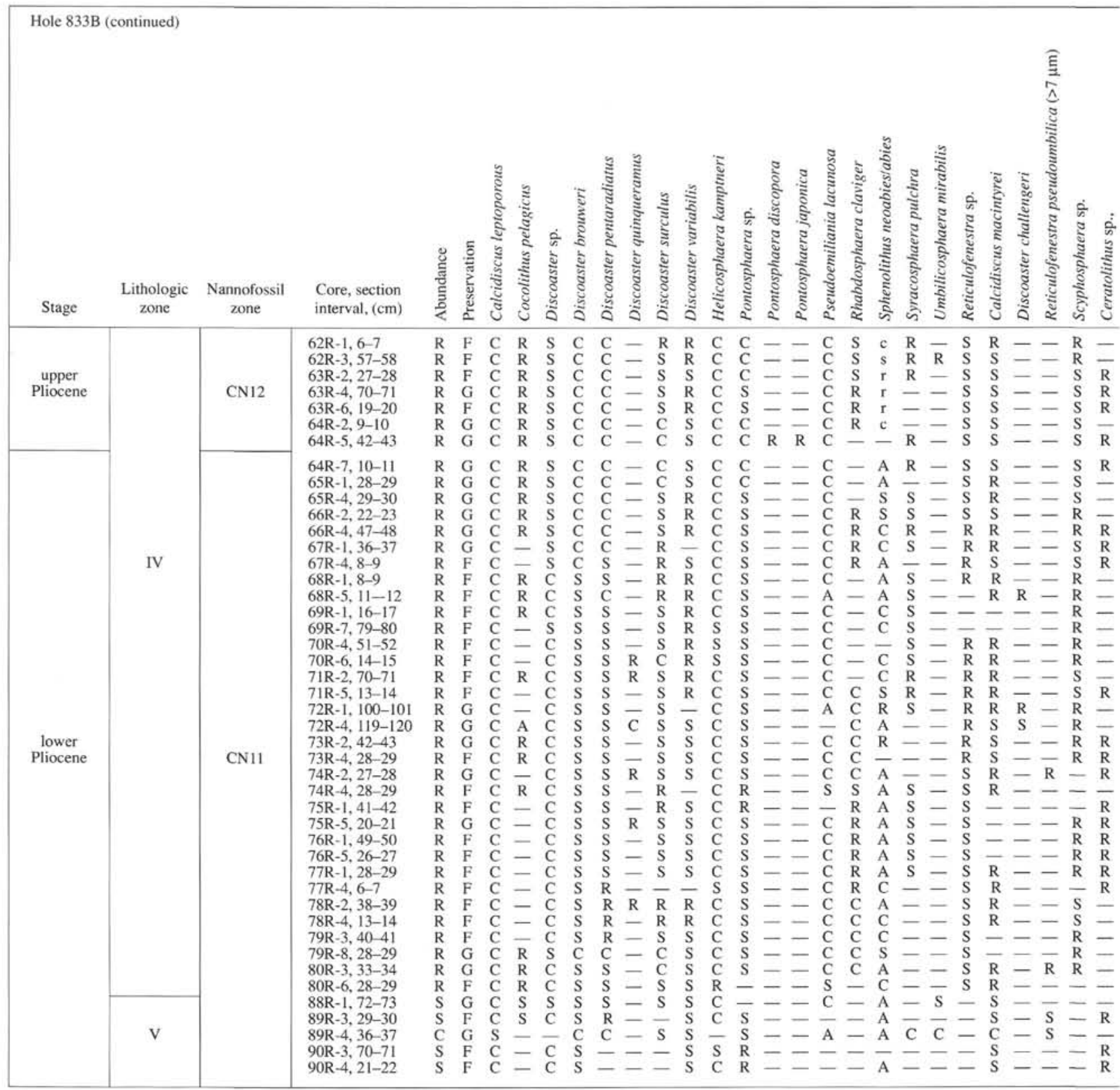

to middle Pleistocene Zone $\mathrm{CN} 14$, which indicates the presence of a second repeated section (Figs. 9 and 17). The first structural evidence for reverse faulting is found just below this level in Section 134829A-17R-5, 80-105 cm (Collot, Greene, Stokking, et al., 1992).

Below Sample 134-829A-19R-4, 86-87 cm, (171.86 mbsf) the biostratigraphic record becomes highly complex, with discrete packages of sediment ranging in thickness from a few meters to over 100 $\mathrm{m}$ separated by numerous shear zones (Meschede and Pelletier, this volume; Collot, Greene, Stokking, et al., 1992) that contain mixed nannofossil assemblages (Fig. 9). A biostratigraphic anomaly in one of these shear zones indicates a possible age reversal. Two samples from Sections 134-829A-43R-1 and -43R-2 lack the upper Eocene marker D. barbadiensis and are dated as early Oligocene, but are sandwiched between upper Eocene samples containing abundant $D$. barbadiensis (Fig. 9). Because the preservation and assemblage abundances are identical in these samples, the age interpretations reflect the in-situ presence of the upper Eocene species. The possibility exists that $D$. barbadiensis may display dramatic fluctuations in abundance at the top of its evolutionary range in this area; however, the last occurrence of this species is generally considered to be sharp and readily identifiable (Wei and Wise, 1989). Considering the structural evidence for a major shear zone encompassing this biostratigraphic anomaly (Fig. 9; Collot, Greene, Stokking, et al., 1992), the reversal of biostratigraphic zones is interpreted as an artifact of slip along the shear zone.

At the base of the major shear zone, below the out-of-sequence lower Oligocene sediments, a third thrust fault is postulated at 400 mbsf (Figs. 9 and 17). The package of sediments containing the upper Eocene, lower Oligocene, and upper to middle Oligocene nannofossil chalks mentioned previously rest upon an interval containing only volcanic breccia. This entire sequence overlies Pleistocene sediments of Zone CN14, which delineates the third thrust fault between Cores 134-829A-43R and -44R (Figs. 9 and 17).

The fourth significant stratigraphic anomaly occurs between Samples $134-829 \mathrm{~A}-47 \mathrm{R}-1,58-59 \mathrm{~cm}$, and $-47 \mathrm{R}-1,100-101 \mathrm{~cm}$, where 
Table 8 (continued).

\begin{tabular}{|c|c|c|c|c|c|c|c|c|c|c|c|c|c|c|c|c|c|}
\hline 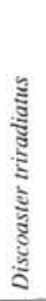 & 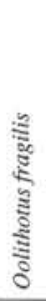 & 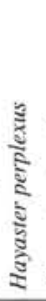 & 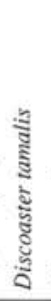 & 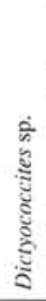 & 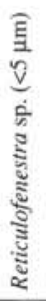 & yे & 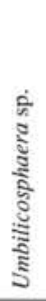 & 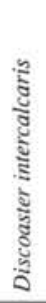 & 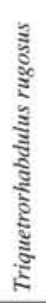 & 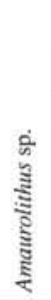 & 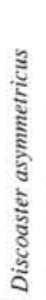 & 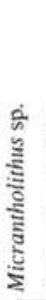 & 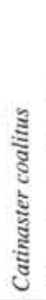 & 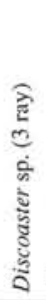 & 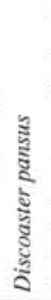 & 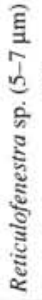 & 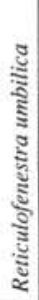 \\
\hline $\mathrm{R}$ & - & $\mathbf{R}$ & $\mathrm{S}$ & - & A & - & - & - & - & - & - & - & - & - & - & - & - \\
\hline $\mathrm{R}$ & - & R & R & - & A & - & - & - & - & - & - & - & - & - & - & - & - \\
\hline$S$ & - & - & $\mathrm{S}$ & - & A & - & - & - & - & - & - & - & - & - & - & - & - \\
\hline S & - & - & $\mathrm{S}$ & - & A & - & - & - & - & - & - & - & - & - & - & - & - \\
\hline $\mathrm{R}$ & - & - & $\mathrm{R}$ & - & A & - & - & - & - & - & - & - & - & - & - & - & - \\
\hline$S$ & - & $\mathrm{R}$ & $\mathrm{R}$ & - & A & - & - & - & - & - & - & - & - & - & - & - & - \\
\hline$S$ & - & & $\mathrm{R}$ & - & $\mathrm{A}$ & - & - & - & - & - & - & - & - & - & - & - & - \\
\hline S & - & R & $S$ & - & A & - & - & - & - & - & - & - & - & - & - & - & - \\
\hline$S$ & - & $\mathrm{R}$ & S & - & A & - & - & - & - & - & - & - & - & - & - & - & - \\
\hline R & - & - & $\mathrm{S}$ & - & A & - & - & - & - & - & - & - & - & - & - & - & - \\
\hline $\mathrm{R}$ & - & $\mathrm{R}$ & $S$ & - & A & $\mathrm{R}$ & - & - & - & - & - & - & - & - & - & - & - \\
\hline R & - & $\mathrm{R}$ & S & - & C & - & - & - & - & - & - & - & - & - & - & - & - \\
\hline $\mathrm{R}$ & - & $\mathrm{R}$ & $\mathrm{S}$ & - & A & R & - & - & - & - & - & - & - & - & - & - & - \\
\hline $\mathrm{R}$ & - & $\mathrm{R}$ & $\mathrm{R}$ & - & A & - & - & - & - & - & - & - & - & - & - & - & - \\
\hline R & - & - & R & - & A & - & - & - & - & - & - & - & - & - & - & - & - \\
\hline R & - & - & $\mathrm{S}$ & - & C & - & - & - & - & - & - & - & - & - & - & - & - \\
\hline- & - & - & $\mathrm{S}$ & - & A & - & - & - & - & - & - & - & - & - & - & - & - \\
\hline- & - & - & - & - & C & - & - & - & - & - & - & - & - & - & - & - & - \\
\hline- & - & $S$ & R & - & A & R & - & - & - & - & - & - & - & - & - & - & - \\
\hline- & - & - & - & - & A & R & - & - & - & - & - & - & - & - & - & - & - \\
\hline- & - & $\mathbf{R}$ & - & - & A & $\mathbf{R}$ & - & - & - & - & - & - & - & - & - & - & - \\
\hline- & - & $\mathbf{R}$ & R & - & C & - & - & - & - & - & - & - & - & - & - & - & - \\
\hline- & - & R & - & - & A & R & - & - & - & - & - & - & - & - & - & - & - \\
\hline $\mathrm{R}$ & - & - & - & - & A & - & $\bar{n}$ & $\mathrm{r}$ & $r$ & - & - & - & - & - & - & - & - \\
\hline R & R & R & $\mathrm{R}$ & - & A & - & $\mathrm{R}$ & - & - & - & - & - & - & - & - & - & - \\
\hline R & $\mathrm{R}$ & $\mathrm{R}$ & $\mathrm{R}$ & - & A & - & $\mathbf{R}$ & - & - & - & - & - & - & - & - & - & - \\
\hline $\mathrm{R}$ & R & - & R & - & A & - & - & - & - & - & - & - & - & - & - & - & - \\
\hline- & - & - & - & - & A & - & - & - & - & - & - & - & - & - & - & - & - \\
\hline $\mathrm{R}$ & - & - & - & - & C & S & $\mathbf{R}$ & - & - & $\mathrm{R}$ & - & - & - & - & - & - & - \\
\hline R & - & - & R & - & C & - & $\mathrm{R}$ & - & - & - & R & - & - & - & - & - & - \\
\hline R & - & - & - & - & C & R & $\mathrm{R}$ & - & - & - & $\mathrm{R}$ & - & - & - & - & - & - \\
\hline R & - & $\mathrm{R}$ & - & - & C & $\mathrm{R}$ & $\mathbf{R}$ & - & - & - & $\mathrm{R}$ & - & - & - & - & - & - \\
\hline R & - & $\mathrm{R}$ & - & - & C & R & $\mathrm{R}$ & - & - & - & $\mathrm{R}$ & $\bar{n}$ & - & - & - & - & - \\
\hline & - & - & - & - & C & - & $\mathrm{R}$ & - & - & - & - & $\mathrm{R}$ & - & - & - & - & - \\
\hline R & - & - & $\mathrm{R}$ & - & C & - & $\mathrm{R}$ & - & - & - & - & - & - & - & - & - & - \\
\hline $\mathbf{R}$ & - & - & $\mathbf{R}$ & - & C & - & $\mathrm{R}$ & - & - & - & - & - & - & - & - & - & - \\
\hline R & - & $\mathbf{R}$ & R & - & A & R & $\mathrm{R}$ & - & - & - & - & - & - & - & - & - & - \\
\hline R & - & $\mathbf{R}$ & $\mathrm{S}$ & - & A & R & $\mathrm{R}$ & - & - & - & - & - & - & - & - & - & - \\
\hline R & - & $\mathrm{R}$ & - & - & - & R & $\mathrm{R}$ & - & - & - & - & - & - & - & - & - & - \\
\hline & - & - & - & - & S & $\mathrm{R}$ & $R$ & - & - & - & - & - & - & - & - & - & - \\
\hline R & - & $\mathbf{R}$ & - & - & - & - & - & - & - & - & - & $\mathrm{R}$ & $r$ & - & - & - & - \\
\hline$\overline{-}$ & $\overline{0}$ & - & $\bar{n}$ & C & A & S & - & - & - & R & $\overline{-}$ & S & $\bar{n}$ & $\mathrm{R}$ & $\bar{x}$ & - & - \\
\hline R & $\mathrm{S}$ & - & R & $\bar{c}$ & - & S & - & - & - & - & $\mathrm{S}$ & - & $\mathrm{R}$ & - & $\mathrm{R}$ & - & - \\
\hline- & - & - & - & S & - & R & - & - & - & - & - & - & - & - & - & C & $\mathbf{r}$ \\
\hline- & - & R & - & - & - & - & - & - & - & - & - & $S$ & - & - & - & C & - \\
\hline
\end{tabular}

once again a clayey chalk of upper Eocene age overlies vitric siltstones of Pleistocene Zone CN14 (Figs. 9 and 17). The Eocene chalk is only about $30 \mathrm{~cm}$ in thickness and is accompanied by less than $1 \mathrm{~m}$ of overlying upper Oligocene chalk. The core recovery was poor across this interval. Logging data is helpful here because the change in lithology from carbonates to clays and vitric sands is mirrored by strong inflections in the calcium yield logs at 420 and $437 \mathrm{mbsf}$ (Fig. 18). An extrapolation of the thicknesses of the carbonate unit (CP19/ $\mathrm{CN} 1$ ) and the carbonate-poor vitric siltstone (CN14) from the logging data enables a reconstruction of the poorly recovered interval. The logs indicate a continuous carbonate unit, approximately $17 \mathrm{~m}$ thick, overlying a carbonate-poor unit approximately $6 \mathrm{~m}$ thick. Thus, almost the entire interval of lost recovery was carbonate and the clayrich Eocene unit is represented in the core by its true thickness.

Despite the revised thickness of the sedimentary units described herein, it could be argued that the short carbonate segments recognized in the core are simply olistoliths bounded by Pleistocene olis- tostromal units both above and below. If these carbonates are simply displaced blocks, however, one would expect them to be accompanied by other components of an olistostromal deposit such as mixed chaotic sediments. There is no evidence in either the cores or the logging data to suggest this, which supports the conclusion that the chalk unit (CP19/CN1) and clayey chalk (CP15) were juxtaposed to the underlying Pleistocene siltstones by a thrust fault. A shear zone containing shear bands and a well-developed planar fabric corresponds to the clayey chalk unit and further supports the interpretation that this is a thrust plane (Collot, Greene, Stokking, et al., 1992).

Another package of progressively older sediments occurs between Samples 134-829A-47R-1, 100-101 cm, and -51R-2,97-99 cm: Pleistocene (CN14) in Cores 134-829A-47R and -48R; lower Miocene or upper Oligocene (CN1/CP19) in Core 134-829A-49R; middle or upper Oligocene in Core 134-829A-50R; upper Eocene through Section 134-829A-51R-2, 97-99 cm; and Pleistocene (CN14) in Samples 134829A-51R-3, 48-49 cm, through -53R-1, 50-51 cm (Figs. 9 and 17). Core recovery was again poor in the carbonate intervals, and logging data are not available. The dramatic age inversion at $463 \mathrm{mbsf}$ documents a 36-m-thick stratigraphic sequence of upper Eocene to Pleistocene strata thrust over Pleistocene deposits. Structural evidence for thrusting in the Eocene unit includes shear bands, rotated sigma clasts, and a well-developed planar fabric (Collot, Greene, Stokking, et al., 1992). Collectively, the paleontological, lithological, and structural data all indicate that a major thrust surface is located at this boundary.

The remaining cores with good nannofossil preservation display various ages and lithologies combined with poor recovery, which complicates biostratigraphic interpretation. From 463.58 to 495.51 mbsf, another sequence that exhibits progressively older ages with depth is indicated by nannofossils. Sediments of Zone CN1 mixed with a presumed in-situ matrix of Pleistocene Zone (CN14) extend from Samples 134-829A-51R-3, 48-49 cm, through -53R-1, 39-40 $\mathrm{cm}$ (Figs. 9 and 17). Underlying this mixed sediment interval, lower Oligocene (CP16) through upper Oligocene (CP18/19) sediments are present downcore to Sample 134-829A-55R-1, 104-105 cm, at which level the middle Oligocene Zone CP17/18 recurs. This anomalous reappearance is similar to the situation described for Core 134-829A43R; however, in this instance there is no strong structural evidence for shearing to explain the minor age reversal. Structural analyses indicate that the unit is highly brecciated with some polished surfaces and slickensides, but these features have not been interpreted by the shipboard structural geologists as evidence of another thrust (Collot, Greene, Stokking, et al., 1992).

Middle Oligocene sediments (Zone CN17/18) extend through the remainder of Core 134-829A-55R (Figs. 9 and 17), below which the lowermost $22 \mathrm{~m}$ of nannofossil-bearing sediments recovered in Hole 829 A contains clasts of various ages within a matrix composed of Pleistocene Zone CN14. Despite the lack of supporting structural evidence, the change from middle Oligocene (CN17/18) to Pleistocene $(\mathrm{CN} 14)$ across this contact at $495 \mathrm{mbsf}$ is interpreted to be another thrust fault.

\section{Time Constraints on Thrusting}

Sediments of uppermost Pleistocene Zone CN15 are identified below the uppermost suspected thrust at Site 829. If all thrusts occurring at the site developed sequentially, migrating the deformation front toward the trench, then all thrusts identified deeper in the hole should be even younger, forming in the latest Pleistocene $(<0.28 \mathrm{Ma})$ or Holocene. The youngest nannofossil ages below the suspected thrust at 401 mbsf are early to middle Pleistocene Zone CN14, providing a maximum age for this thrust fault. These lower thrusts may have formed earlier than the upper two thrusts, which would then be out-of-sequence thrusts.

Previously thrusted packages, if they exist, should be found upslope. Site 827 is located upslope and north of Site 829 , but unfortunately recovered only a shallow interval that found only one possible 


\section{A}

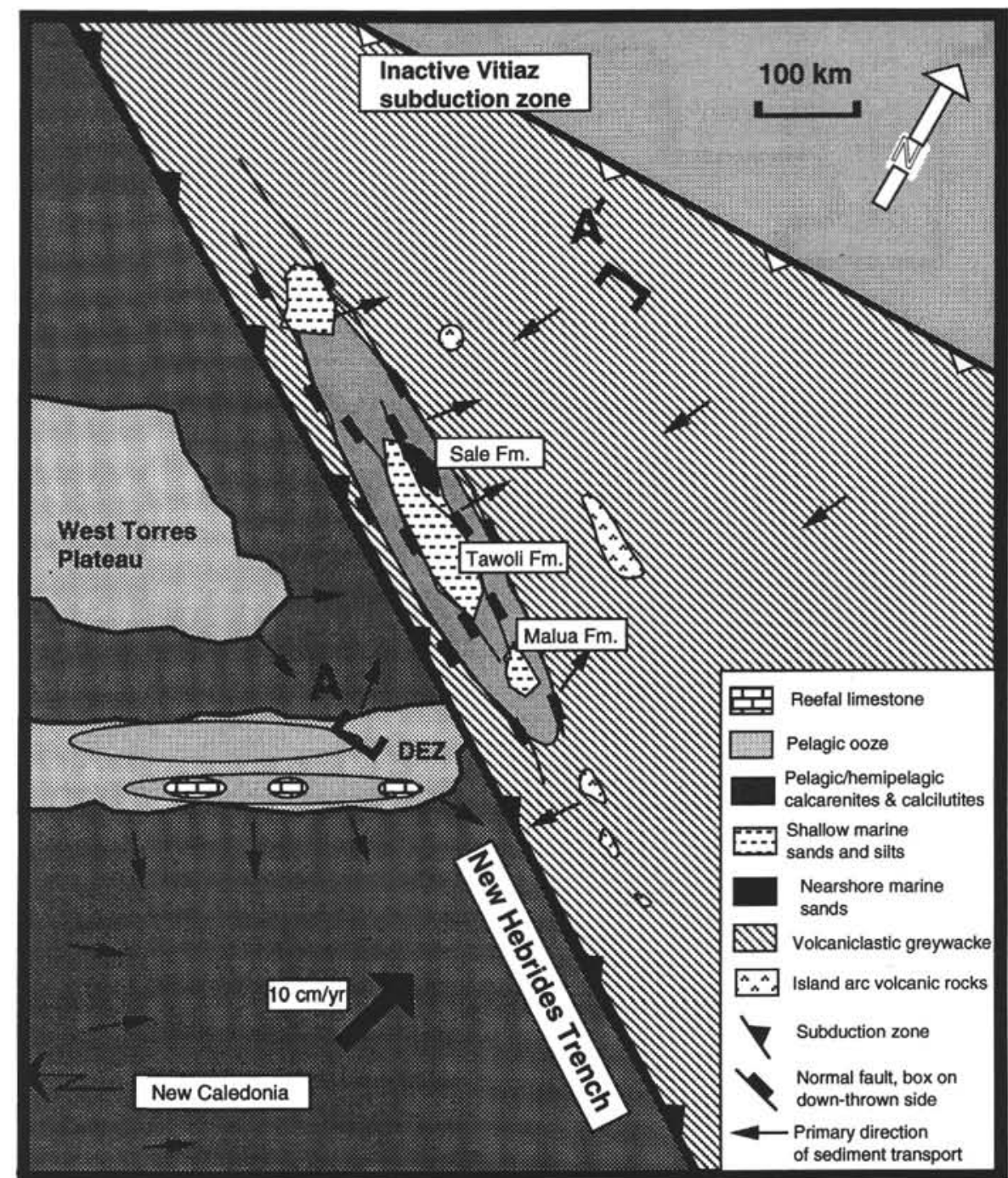

\section{B}

A

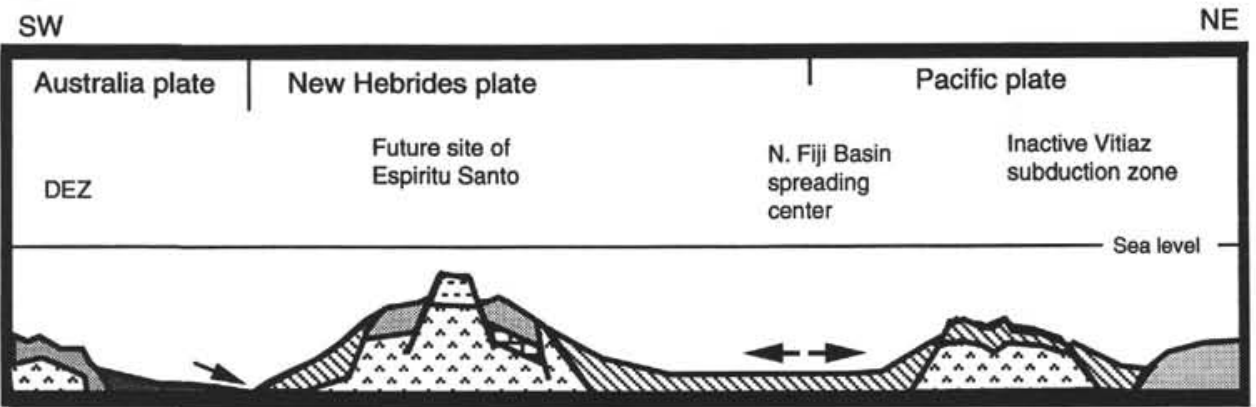

Not to scale

Figure 13. A. Inferred paleogeography of central New Hebrides Arc during the Pliocene. B. Cross-sectional model $\left(\mathrm{A}-\mathrm{A}^{\prime}\right)$ of the paleogeography of the central New Hebrides Island Arc during the Pliocene. Modified from Greene et al. (1988). 
A

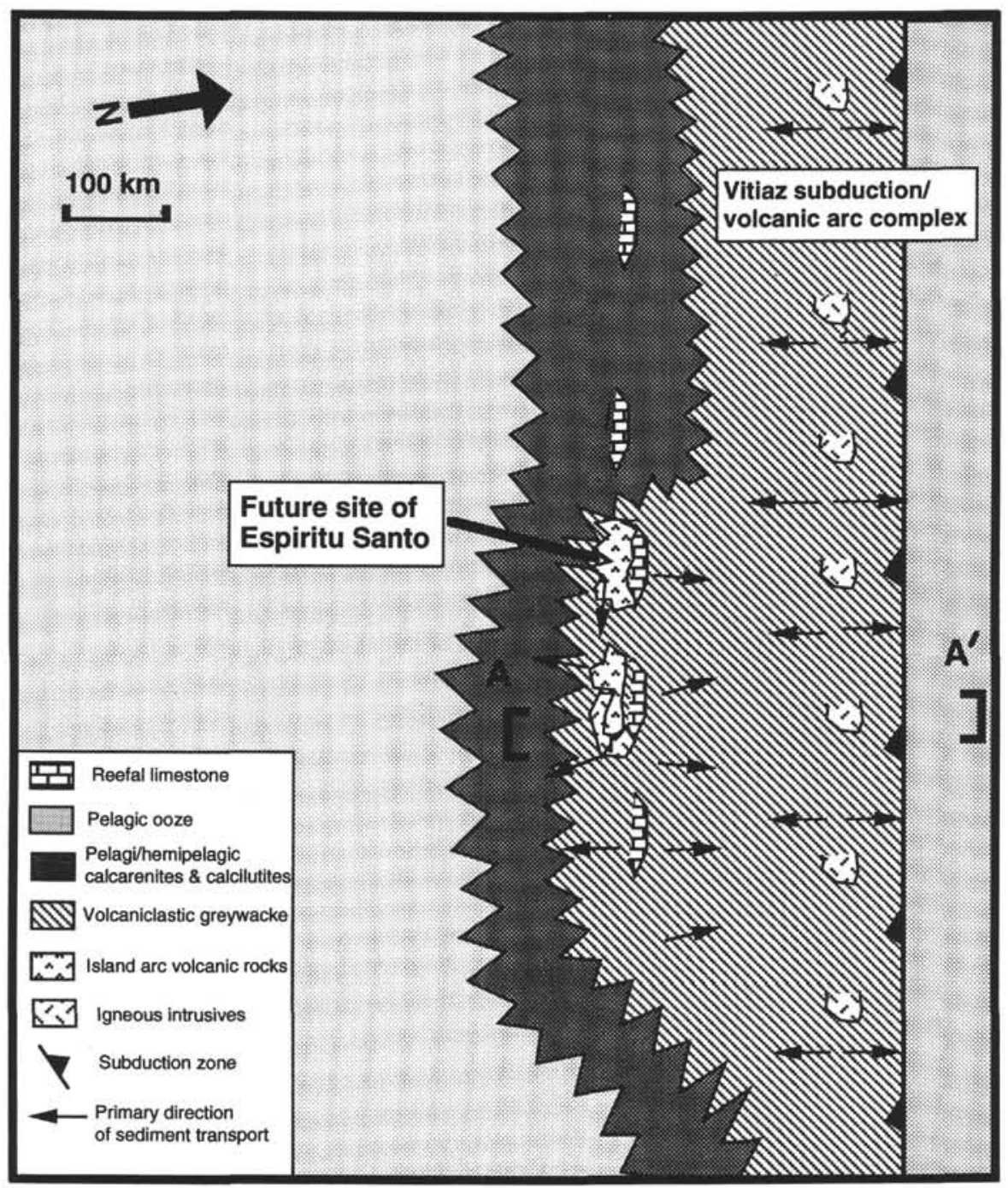

B

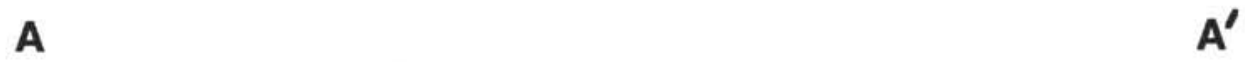

SW

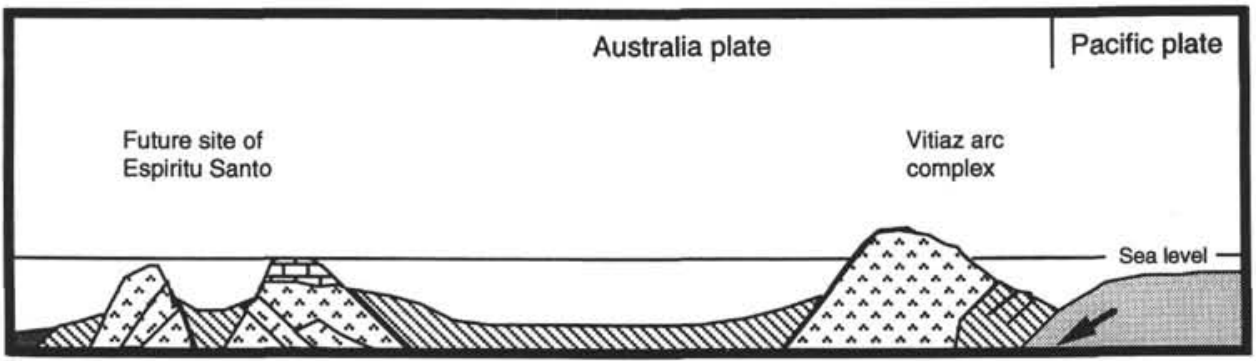

Not to scale

Figure 14. A. Inferred paleogeography of central New Hebrides Arc from late Oligocene through middle Miocene. B. Cross-sectional model $\left(\mathrm{A}-\mathrm{A}^{\prime}\right)$ of the paleogeography of the central New Hebrides Island Arc during the late Oligocene through the middle Miocene. Modified from Greene et al. (1988). 


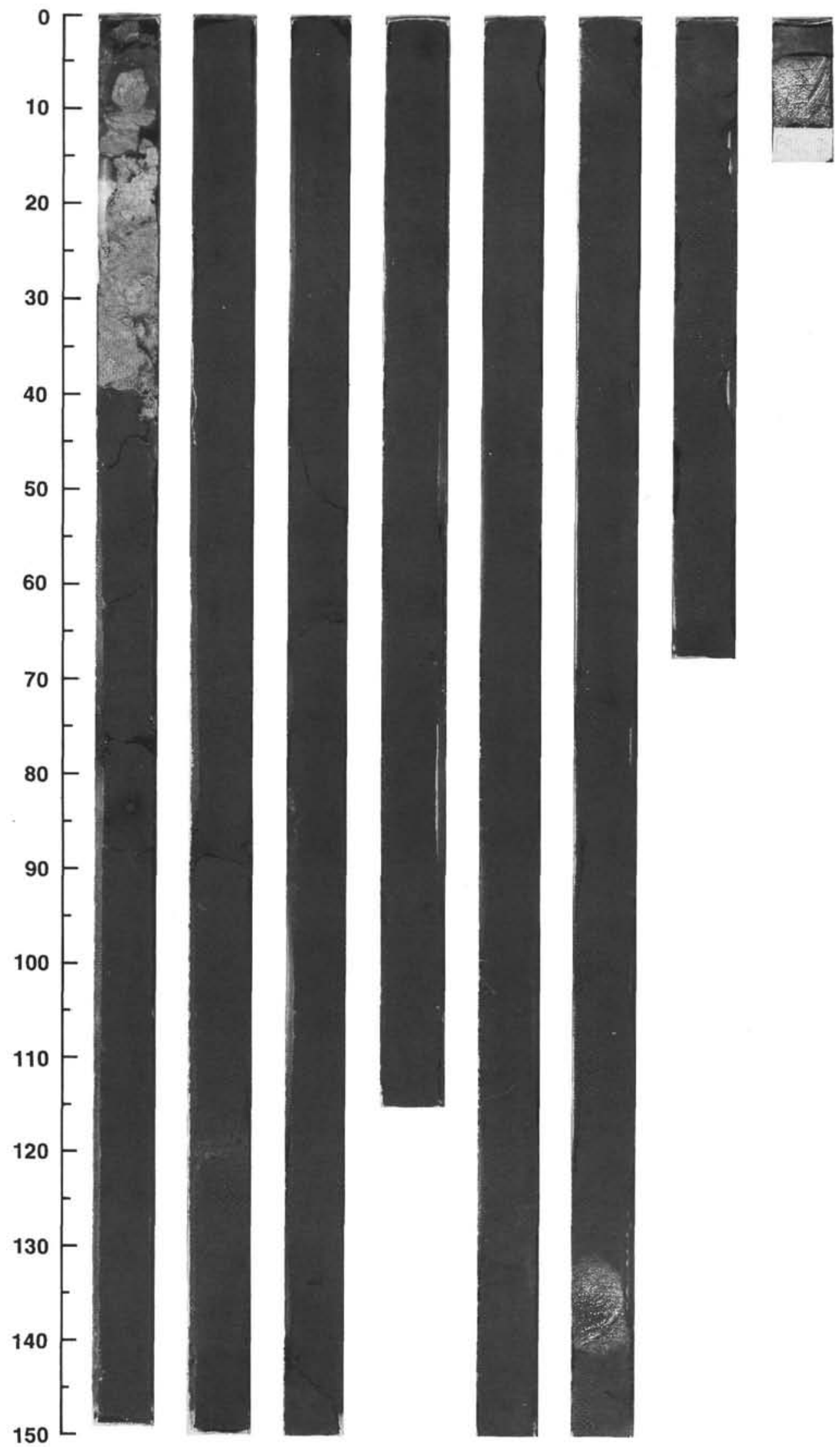

Figure 15. Photograph of Core 134-829A-12R, showing the contact between the middle Oligocene chalk of unit II and the underlying Pleistocene volcanic siltstones of Unit III represented by an abrupt change in composition at $40 \mathrm{~cm}$. 
thrust (Fig. 8). The sediments just below the suspected thrust are early to middle Pleistocene (CN14), which constrains the age of thrusting at this site to that age or younger.

\section{Sediment Mixing}

Another difficult problem is to distinguish the possible mechanisms that produced the mixed-age sediments at Site 829. Two primary mechanisms are evoked to explain the incorporation of Pleistocene sediment with older chalks. Normally, reworking would account for the presence of the older microfossil specimens; however, in intervals where there is structural evidence for intense shearing, tectonic mixing must also be considered.

The composition and possible source areas of the olistostromal sediments now located in the forearc have been compared with sediments interpreted as scraped from the downgoing NDR. The presence of abundant clasts within the olistostromes suggests that at least some of the mixed assemblages from Hole 829A are depositional in origin. For example, clasts of the Pliocene (CN11?), middle and lower Miocene (CN4 and CN1), and middle and upper Oligocene (CP19-17) are found within a predominately Pleistocene matrix. In other instances, severe brecciation mixes clast-derived particles with matrix. The possibility that structural movement along shear zones has in areas affected mixing of the matrix is discussed in the following.

The matrix varies from entirely Pleistocene to Pleistocene with mixed-aged sediment. Because color and texture do not change significantly in the matrix, the distinction between the purely Pleistocene and the Pleistocene-mixed matrices is based solely on nannofossil content (3-25 $\mu \mathrm{m}$-sized particles). Unlike examples from Holes $828 \mathrm{~A}$ and $827 \mathrm{~A}$ in which particle reworking of older taxa into younger sediment is the only process interpreted to have mixed assemblages, sediments recovered below 171.86 mbsf in Hole 829A show signs of shearing that may well have tectonically mixed the strata. Comparison of the structural data with zones interpreted to contain mixed nannofossil assemblages suggests that tectonic mixing is only a secondary cause of mixing, because mixed sediments occur both with and without associated structural deformation.

The uppermost zone of mixed sediments occurs in Core 134-829A$21 \mathrm{R}$, where structural studies indicate a major shear zone. The sedimentological interpretation classifies this zone as a trench-fill deposit, in which abundant clasts float in a matrix of mixed age (Reid et al., this volume; Collot, Greene, Stokking, et al., 1992). Despite evidence for shearing, the mixing in this interval can adequately be explained as the product of deposition. The degree of brecciation of the clasts appears to be greater in the shear zone than in the structurally unaltered portions of the core; however, a clear distinction between clasts and matrix is evident throughout the core (Fig. 19). A more intense and prolonged brecciation process must occur if the sediments are to be homogenized to the degree seen within the matrix. It is, therefore, reasonabie to suggest that in this interval structural deformation has acted as a secondary mechanism in mixing the matrix.

Between 210 and $370 \mathrm{mbsf}$ the sediment is heavily brecciated, but with the exception of limited occurrences of scaly fabric, shows no structural complexity. Clasts within a matrix containing mixed assemblages are common. Also present are second-generation clasts, specifically Miocene to Oligocene (Zone CN1/CP19) clasts within larger clasts of the same age. In the top of Section 134-829A-27R-1 a shear zone showing well-developed foliation indicative of "ductile-type" deformation is recorded (Collot, Greene, Stokking, et al., 1992), but this interval does not indicate mixed ages. Collectively, these data suggest that any mixing attributed to structural movement is subordinate to that created by depositional processes across the trench slope. Where mixing can be attributed in part to tectonic processes, brittle deformation has acted only as a minor mixing agent, whereas the ductile-type behavior observed in the clays has had no apparent mixing effect.
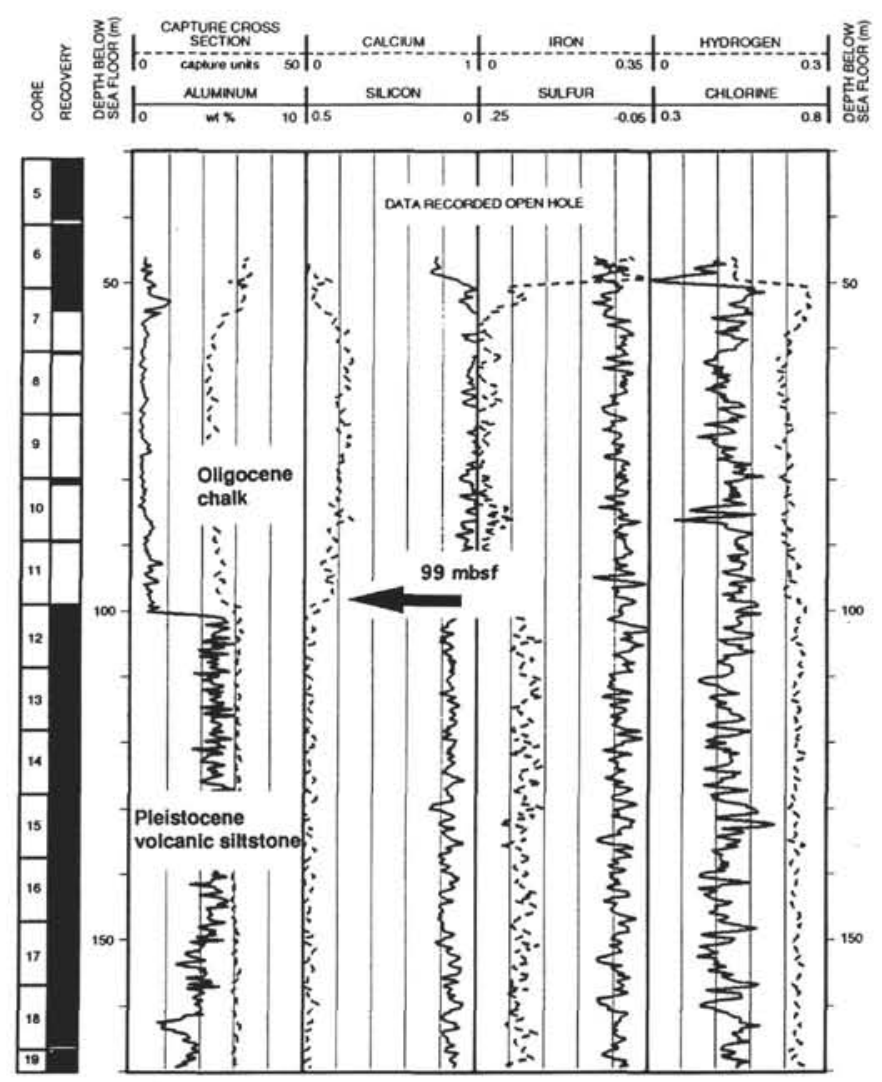

Figure 16. Calcium yield $\log$ from Hole $829 \mathrm{~A}$, showing a significant inflection at 99 mbsf, which corresponds to the lithologic change between the middle Oligocene chalk of Unit II and the underlying Pleistocene volcanic siltstones of Unit III.

Samples from Core 134-829A-51R display both ductile-type and brittle deformation (Collot, Greene, Stokking, et al., 1992). Eocene deposits show well-developed foliation that include shear bands and clasts with pressure shadows that show a reverse sense of movement (Meschede and Pelletier, this volume; Collot, Greene, Stokking, et al., 1992) (Fig. 20). Neither mixing nor brecciation is evident in this shear zone despite intense deformation that results from ductile behavior within clay-rich intervals. Conversely, brecciation is prevalent throughout the interval from Samples 134-829A-51R-2, $55 \mathrm{~cm}$, to -51R-2, 106 $\mathrm{cm}$. This interval has been interpreted to be a later stage of brittle deformation affecting the original shear zone (Collot, Greene, Stokking, et al., 1992). Lower Miocene to upper Oligocene clasts (Zone CN1/ $\mathrm{CP} 19)$ are present within a lower Oligocene (CP16) matrix. Both the clasts and the matrix are younger than the surrounding Eocene units. Although no microscopic sediment mixing is evident in the matrix, the presence of the lower Miocene to upper Oligocene clasts (Zone CN1/ CP19) suggests sediment mixing on the macroscopic level. This sediment mixing most likely resulted from brittle deformation. The absence of Pleistocene nannofossils suggests that this interval did not originate in the trench, as an olistostromal deposit like the previously mentioned intervals containing clasts and mixed assemblages.

Nannofossil and foraminifer analyses of the samples collected by SUBPSO 1 dives 2-4 discussed earlier also suggest a high degree of age variation and sediment mixing within the rocks of the forearc (Collot et al., 1992). Samples containing minor quantities of Quaternary species mixed with older fossils were interpreted by the SUBPSO 1 paleontologists as evidence for either massive reworking or contamination. In light of the evidence from Leg 134 cores, sediment mixing by depositional and possibly tectonic processes best explains 


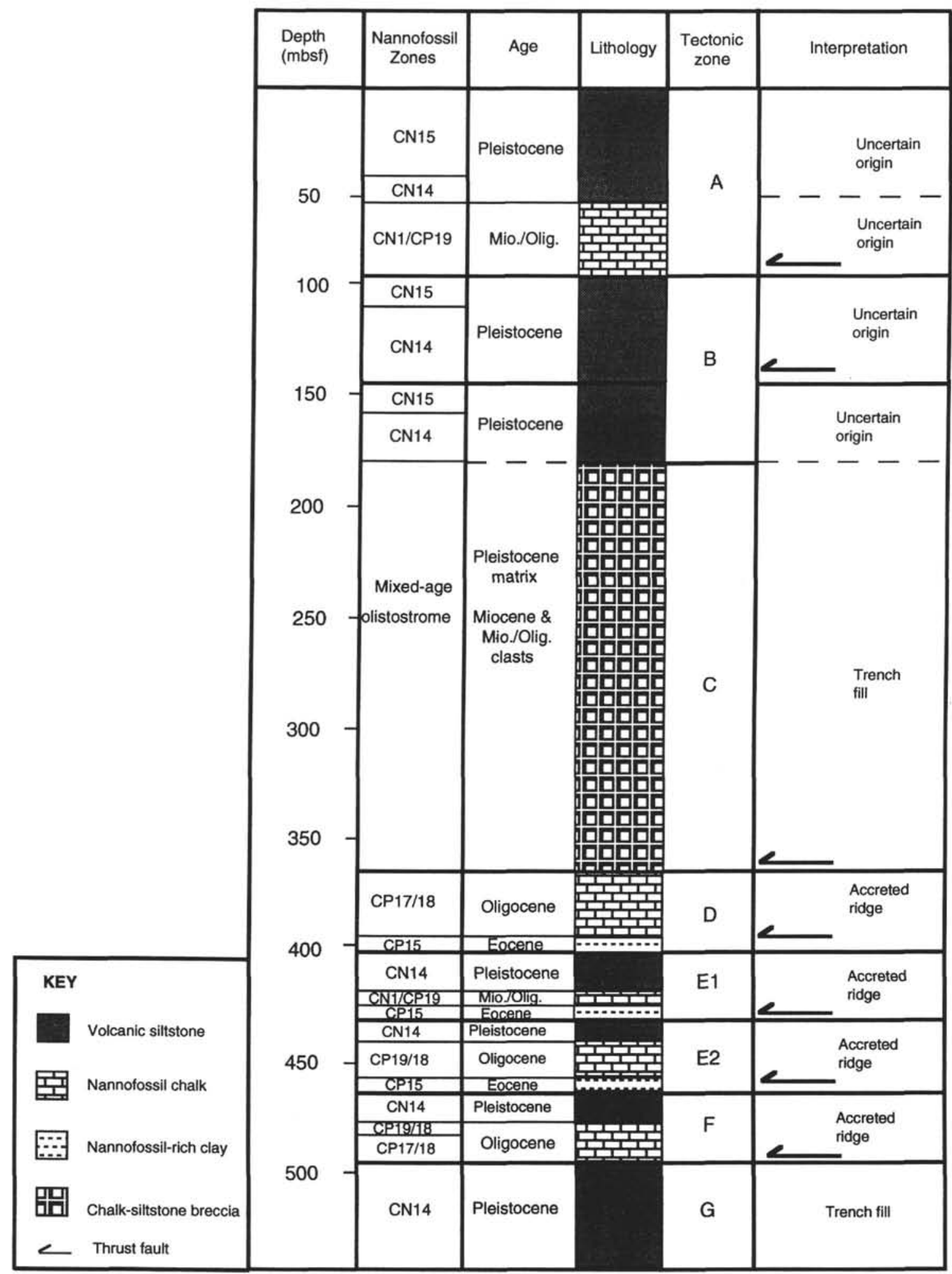

Figure 17. Summary of the major biostratigraphic units, lithologies, and tectonic zones at Hole 829A. Detailed descriptions of the biostratigraphy are from this paper and both the lithologic units and tectonic zones are from Collot, Greene, Stokking, et al., (1992). Interpreted thrust faults are denoted by the arrows in the interpretation column. 
the minor quantities of Quaternary species documented from the Nautile dive samples. Massive downslope movement of early Miocene and older sediment during the formation of olistostromal deposits has most likely diluted the Pleistocene microfossil assemblage in sediments from both Site 829 and the Nautile dives. Therefore, the mixed assemblages noticed in the dive samples and in Hole 829A result from the same sedimentologic and tectonic processes acting on the trench slope.

\section{SUMMARY AND CONCLUSIONS}

The calcareous nannofossil biostratigraphy and characteristics of abundance and preservation have been worked out in detail for seven ODP Leg 134 sites drilled in the central New Hebrides Island Arc. The nannofossil data are primarily semiquantitative, with abundance counts made only for selected problematic intervals in the upper Pleistocene. Owing to the varied depositional environments, the abundance and preservation of the nannofossils are highly variable. Nevertheless, this study clearly documents the age relationships of sediment scraped from a bathymetric high on the subducting oceanic crust (DEZ) and accreted to the forearc at an intraoceanic subduction zone (Fig. 21). Detailed sampling of cored sediment from two reference sections drilled on the downgoing Australia plate, in conjunction with paleontological and sedimentological reports from DSDP Site 286 and the neighboring islands, provides sufficient data to discuss the probable origin of the sediments now residing in the lower trench slope.

Upper Eocene, lower and middle Oligocene, and possibly upper Oligocene to lower Miocene strata were scraped from the downgoing NDR during the Pleistocene. Pliocene, middle Miocene, and possibly lower Miocene to upper Oligocene material appear as clasts and olistoliths in a matrix of Pleistocene or mixed sediments. Despite the absence of a deep trench where the DEZ abuts the arc, the mixed sediments appear to be primarily the result of olistostromal deposition in a trough located between the subducting NDR and the forearc. These trench sediments then underwent deformation, evidenced by shear zones, which further brecciated and mixed the sediments. Other shear zones exhibit planar fabric indicative of ductile-type behavior but do not contain mixed-age matrixes, nor does the one brittle shear zone not associated with Pleistocene olistostromes. This suggests that any sediment mixing attributable to tectonic movement in the forearc is subordinate to sediment mixing by depositional processes.

Nannofossil biostratigraphy also helps constrain the timing of the encounter of the NDR with the New Hebrides Arc. The increasing quantity of volcanic silt in the middle to lower Pleistocene sediments from Hole $828 \mathrm{~A}$ indicates a minimum age for sediment plumes originating from the forearc to have reached the NDR.

An unconformity determined by nannofossil biostratigraphy to separate upper Pliocene and middle Pleistocene sediments at Site 832 suggests that downwarping of the NAB likely occurred within the time interval represented by these missing sediments. The collision of the NDR with the arc is the proposed mechanism that downwarped the NAB. Nannofossil biostratigraphy of Site 832, therefore, supports the theory that the collision of the NDR with Espiritu Santo Island began in the early Pleistocene or late Pliocene. However, because the DEZ is slowly moving to the north at approximately $3-4 \mathrm{~cm} / \mathrm{yr}$, the initial collision between the DEZ and the New Hebrides Island Arc may have occurred earlier at Malakula Island.

\section{ACKNOWLEDGMENTS}

I gratefully acknowledge Captain Edwin G. Oonk and the crew of the SEDCO BP471 and the scientific and support personnel of the Ocean Drilling Program on Leg 134. I would also like to thank the reviewers, Co-Chief Scientists, and Staff Scientist for their helpful suggestions on the manuscript. Special thanks go to Drs. S.W. Wise, Jr., P. Reid, N. Lundberg, and members of my thesis committee for their timely discussions and suggestions during all phases of this
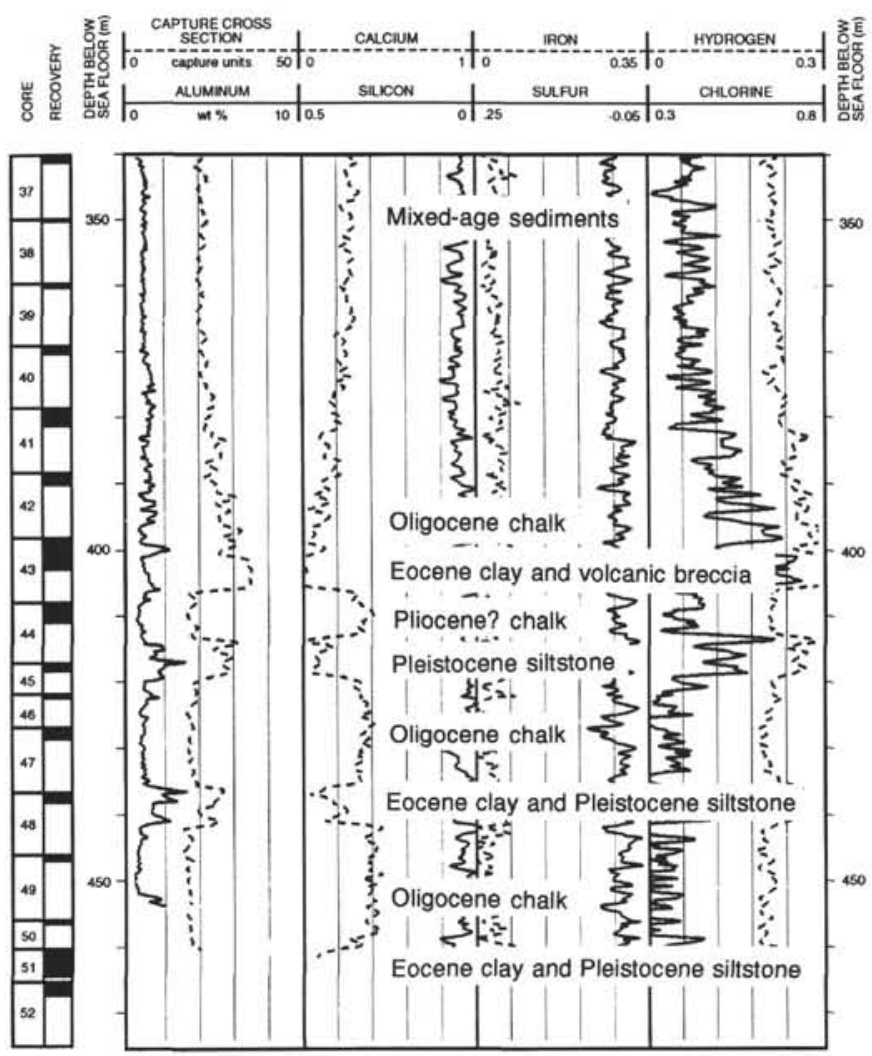

Figure 18. Calcium yield $\log$ from Hole 829 A showing a $17 \mathrm{~m}$ carbonate unit bounded by strong inflections at 419 and 436 mbsf. These changes in log character correspond to the sharp lithologic contact between Pleistocene volcanic siltstone to upper Oligocene chalk at 419 mbsf and between upper Oligocene chalk to upper Eocene clay at 436 mbsf.

project. Li Liu and Kim Riddle of Florida State University provided laboratory and SEM assistance, respectively. J. Michener Covington was instrumental in data entry and range chart preparation by providing consultation on the use of his Bugware paleontological program.

This research was supported by a JOI/USSAC grant to T.S. Staerker. Laboratory equipment and facilities were provided by NSF grants DPP 89-17976 and 91-18480. This study is based on work undertaken as part of a Masters thesis in Geology at Florida State University.

\section{REFERENCES}

Backman, J., 1986. Late Paleocene to middle Eocene calcareous nannofossil biostratigraphy from the Shatsky Rise, Walvis Ridge and Italy. Palaeogeogr., Palaeoclimatol., Palaeoecol., 57:43-59.

Backman, J., and Hermelin, J.O.R., 1986. Morphometry of the Eocene nannofossil Reticulofenestra umbilicus lineage and its biochronological consequences. Palaeogeogr., Palaeoclimatol., Palaeoecol., 57:103-116.

Backman, J., and Pestiaux, P., 1987. Pliocene Discoaster abundance variations, Deep Sea Drilling Project Site 606: biochronology and paleoenvironmental implications. In Ruddiman, W.F., Kidd, R.B., Thomas, E., et al., Init. Repts. DSDP, 94 (Pt. 2): Washington (U.S. Govt. Printing Office), 903-910.

Backman, J., Schneider, D.A., Rio, D., and Okada, H., 1990. Neogene lowlatitude magnetostratigraphy from Site 710 and revised age estimates of Miocene nannofossil datum events. In Duncan, R.A., Backman, J., Peterson, L.C., et al., Proc. ODP, Sci. Results, 115: College Station, TX (Ocean Drilling Program), 271-276.

\footnotetext{
Abbreviations for names of organizations and publications in ODP reference lists follow the style given in Chemical Abstracts Service Source Index (published by American Chemical Society).
} 
Backman, J., and Shackleton, N.J., 1983. Quantitative biochronology of Pliocene and early Pleistocene calcareous nannofossils from the Atlantic, Indian and Pacific oceans. Mar. Micropaleontol., 8:141-170.

Barsdell, M., 1976. Eastern Cumberland Peninsula, North Santo. New Hebrides Geol. Surv. Ann. Rep., 2-8.

Berggren, W.A., Kent, D.V., and Flynn, J.J., 1985. Jurassic to Paleogene: Part 2. Paleogene geochronology and chronostratigraphy. In Snelling, N.J. (Ed.), The Chronology of the Geological Record. Geol. Soc. London Mem., 10:141-195.

Berggren, W.A., Kent, D.V., and Van Couvering, J.A., 1985. The Neogene: Part 2. Neogene geochronology and chronostratigraphy. In Snelling, N.J. (Ed.), The Chronology of the Geological Record. Geol. Soc. London Mem., 10:211-260.

Boudreaux, J.E., and Hay, W.W., 1969. Calcareous nannoplankton and biostratigraphy of the late Pliocene-Pleistocene-Recent sediments in the submarex cores. Rev. Esp. Micropaleontol., 1:249-292.

Bukry, D., 1973. Low-latitude coccolith biostratigraphic zonation. In Edgar, N.T., Saunders, J.B., et al., Init. Repts. DSDP, 15: Washington (U.S. Govt. Printing Office), 685-703.

Bukry, D., and Bramlette, M.N., 1969. Some new and stratigraphically useful calcareous nannofossils of the Cenozoic. Tulane Stud. Geol. Paleontol., 7:131-142.

Burne, R.V., Collot, J.-Y., and Daniel, J., 1988. Superficial structures and stress regimes of the downgoing plate associated with subduction-collision in the Central New Hebrides Arc (Vanuatu). In Greene, H.G., and Wong, F.L. (Eds.), Geology and Offshore Resources of Pacific Island Arcs-Vanuatu Region. Circum-Pac. Counc. Energy Miner. Resour., Earth Sci. Ser., 8:357-376.

Carney, J.N., 1985. Geology and Mineralisation of North and Central Malekula. Vanuatu Dep. Geol., Mines and Rural Water Suppl. Rep.

Carney, J.N., and Macfarlane, A., 1985. Geology and Mineralisation of the Cumberland Peninsula, North Espiritu Santo. Vanuatu Dep. Geol., Mines and Rural Water Suppl. Rep.

Chase, T.E., and Seekins, B.A., 1988. Submarine topography of the Vanuatu and southeastern Solomon Islands region. In Greene, H.G., and Wong, F.L. (Eds.), Geology and Offshore Resources of Pacific Island Arcs-Vanuatu Region. Circum-Pac. Counc. Energy Miner. Resour., Earth Sci. Ser., 8:35-36.

Chung, W.Y., and Kanamori, H., 1978. A mechanical model for plate deformation associated with aseismic ridge subduction in the New Hebrides arc. Tectonophysics, 50:29-40.

Collot, J.-Y., Daniel, J., and Burne, R.V., 1985. Recent tectonics associated with the subduction/collision of the d'Entrecasteaux zone in the central New Hebrides. Tectonophysics, 112:325-356.

Collot, J.-Y., and Fisher, M.A., 1989. Stages of structural evolution of an accretionary complex: effects of collision between seamounts, ridges, and the New Hebrides island arc. 28th Int. Geol. Congr., Washington, D.C., 1:315. (Abstract)

1991. The collision zone between the North d'Entrecasteaux Ridge and the New Hebrides Island Arc. Part 1: Seabeam morphology and shallow structure. J. Geophys. Res., 96:4457-4478.

, 1992. The D'Entrecasteaux Zone-New Hebrides Island Arc collision zone: an overview. In Collot, J.-Y., Greene, H.G., Stokking, L.B., et al., Proc. ODP, Init. Repts., 134: College Station, TX (Ocean Drilling Program), 19-31.

Collot, J.-Y., Greene, H.G., Stokking, L.B., et al., 1992. Proc. ODP, Init. Repts., 134: College Station, TX (Ocean Drilling Program).

Collot, J.-Y, Lallemand, S., Pelletier, B., Eissen, J.-P., Glaçon, G., Fisher, M.A., Greene, H.G., Boulin, J., Daniel, J., and Monzier, M., 1992. Geology of the d'Entrecasteaux-New Hebrides Arc collision zone: results from a deep submersible survey. Tectonophysics, 212:213-241.

Collot, J.-Y., Pelletier, B., Boulin, J., Daniel, J., Eissen, J.P., Fisher, M.A., Greene, H.G., Lallemand, S., and Monzier, M., 1989. Premiers résultats des plongees de la campagnee SUBPSO1 dans la zone de collision des rides d'Entrecasteaux et de l'arc des Nouvelles Hébrides. C. R. Acad. Sci. Ser. 2, 309:1947-1954.

Daniel, J., Collot, J.Y., Monzier, M., Pelletier, B., Butscher, J., Deplus, C., Dubois, J., Gérard, M., Maillet, P., Monjaret, M.C., Récy, J., Renard, V. Rigolot, P., and Temakon, S.J., 1986. Subduction et collision le long de l'arc des Nouvelles-Hébrides (Vanuatu): résultats préliminaires de la campagne SEAPSO (Leg 1). C. R. Acad. Sci. Ser. 2, 303:805-810.

Daniel, J., Jouannic, C., Larue, B., and Récy, J., 1977. Interpretation of d'Entrecasteaux zone (north of New Caledonia). Int. Symp. on Geodynamics in South-west Pacific. Noumea, New Caledonia, 1976. Paris (Editions Technip), 117-124.
Daniel, J., and Katz, H.R., 1981. D'Entrecasteaux zone, trench and western chain of the central New Hebrides island arc: their significance and tectonic relationship. Geo-Mar. Lett., 1:213-219.

Dubois, J., Deplus, C., Diament, M., Daniel, J., and Collot, J.-Y., 1988. Subduction of the Bougainville seamount (Vanuatu): mechanical and geodynamic implications. Tectonophysics, 149:111-119.

Duplessy, J.-C., Moyes, J., Pujol, C., Pujos-Lamy, A., and Reyss, J.L., 1975. Stratigraphie des depots quaternaires d'une carotte prelevee au N.E. des Acores. C.R. Acad. Sci. Ser. 2, 281D:1971-1974.

Fisher, M.A., 1986. Tectonic processes at the collision of the D'Entrecasteaux zone and the New Hebrides island arc. J. Geophys. Res., 91:10470-10486.

Fisher, M.A., Collot, J.-Y., and Geist, E.L., 1991. The collision zone between the North d'Entrecasteaux Ridge and the New Hebrides Island Arc. Part 2: structure from multichannel seismic data. J. Geophys. Res., 96:44794495.

Fisher, M.A., Falvey, D.A., and Smith, G.L.. 1988. Seismic stratigraphy of the summit basins of the New Hebrides island arc. In Greene, H.G., and Wong, F.L. (Eds.), Geology and Offshore Resources of Pacific Island ArcsVanuatu Region. Circum-Pac. Counc. Energy Miner. Resour., Earth Sci. Ser., 8:201-223.

Fornaciari, E., Raffi, I., Rio, D., Villa, G., Backman, J., and Olafsson, G., 1990. Quantitative distribution patterns of Oligocene and Miocene calcareous nannofossils from the western equatorial Indian Ocean. In Duncan, R.A., Backman, J., Peterson, L.C., et al., Proc. ODP, Sci. Results, 115: College Station, TX (Ocean Drilling Program), 237-254.

Gartner, S., 1972. Late Pleistocene calcareous nannofossils in the Caribbean and their interoceanic correlation. Palaeogeogr., Palaeoclimatol., Palaeoecol., 12:169-191.

1977. Calcareous nannofossil biostratigraphy and revised zonation of the Pleistocene. Mar. Micropaleontol., 2:1-25.

Greene, H.G., Collot, J.-Y., Pelletier, B., and Lallemand, S., 1992. Observation of forearc seafloor deformation along the north D'Entrecasteaux RidgeNew Hebrides Island Arc collision zone from Nautile submersible. In Collot, J.-Y., Greene, H.G., Stokking, L.B., et al., Proc. ODP, Init. Repts., 134: College Station, TX (Ocean Drilling Program), 43-53.

Greene, H.G., and Johnson, D.P., 1988. Geology of the Central Basin region of the New Hebrides Arc inferred from single-channel seismic-reflection data. In Greene, H.G., and Wong, F.L. (Eds.), Geology and Offshore Resources of Pacific Island Arcs-Vanuatu Region. Circum-Pac. Counc. Energy Miner. Resour., Earth Sci. Ser., 8:177-200.

Greene, H.G., Macfarlane, A., Johnson, D.A., and Crawford, A.J., 1988. Structure and tectonics of the central New Hebrides Arc. In Greene, H.G., and Wong, F.L. (Eds.), Geology and Offshore Resources of Pacific Island Arcs-Vanuatu Region. Circum-Pac. Counc. Energy Miner. Resour., Earth Sci. Ser., 8:377-412.

Hay, W.W., 1970. Calcareous nannofossils from cores recovered on Leg 4. In Bader, R.G., Gerard, R.D., et al., Init. Repts. DSDP, 4: Washington (U.S. Govt. Printing Office), 455-501.

Kamptner, E., 1943. Zur Revision der Coccolithineen-Spezies Pontosphaera huxleyi Lohm. Akad. Wiss. Wien, Math.-Naturwiss. Kl., Anz., 80:43-49.

Klein, G.deV., 1975. Depositional facies of Leg 30 Deep Sea Drilling Project sediment cores. In Andrews, J.E., Packham, G., et al., Init. Repts. DSDP, 30: Washington (U.S. Govt. Printing Office), 423-442.

Loeblich, A.R., and Tappan, H., 1978. The coccolithophorid genus Calcidiscus Kamptner and its synonyms. J. Paleontol., 52:1390-1392.

Macfarlane, A., Carney, J.N., Crawford, A.J., and Greene, H.G., 1988. Vanuatu-a review of the onshore geology. In Greene, H.G., and Wong, F.L. (Eds.), Geology and Offshore Resources of Pacific Island Arcs-Vanuatu Region. Circum-Pac. Counc. Energy Miner. Resour., Earth Sci. Ser., 8:45-91.

Maillet, P., Monzier, M., Selo, M., and Storzer, D., 1983. The d'Entrecasteaux zone (southwest Pacific). A petrological and geochronological reappraisal. Mar. Geol., 53:179-197.

Mallick, D.I.J., and Greenbaum, D., 1977. Geology of Southern Santo. Reg. Rep.-New Hebrides Geol. Surv.

Mallick, D.I.J., and Neef, G., 1974. Geology of Pentecost. Reg. Rep.-New Hebrides Geol. Surv.

Martini, E., 1971. Standard Tertiary and Quaternary calcareous nannoplankton zonation. In Farinacci, A. (Ed.), Proc. 2nd Int. Conf. Planktonic Microfossils Roma: Rome (Ed. Tecnosci.), 2:739-785.

Matsuoka, H., and Okada, H., 1989. Quantitative analysis of Quaternary nannoplankton in the subtropical northwestern Pacific Ocean. Mar. Micropaleontol., 14:97-118. 
1990. Time-progressive morphometric changes of the genus Gephyrocapsa in the Quaternary sequence of the tropical Indian Ocean. In Duncan, R.A., Backman, J., Peterson, L.C., et al., Proc. ODP, Sci. Results, 115: College Station, TX (Ocean Drilling Program), 255-270.

McIntyre, A., and McIntyre, R., 1971. Coccolith concentrations and differential solution in oceanic sediments. In Funnel, B.M., and Riedel, W.R. (Eds.), The Micropaleontology of Oceans: London (Cambridge Univ. Press), 253-261.

Mitchell, D.I.J., 1966. Geology of South Malekula. New Hebrides Geol. Surv. Rep., 3:1-41.

1971. Geology of Northern Malekula. New Hebrides Geol. Surv. Rep., 1-56.

Okada, H., and Bukry, D., 1980. Supplementary modification and introduction of code numbers to the low-latitude coccolith biostratigraphic zonation (Bukry, 1973; 1975). Mar. Micropaleontol., 5:321-325.

Perch-Nielsen, K., 1985. Cenozoic calcareous nannofossils. In Bolli, H.M., Saunders, J.B., and Perch-Nielsen, K. (Eds.), Plankton Stratigraphy: Cambridge (Cambridge Univ. Press), 427-554.

Proto Decima, F., and Masotti, C., 1981. The genus Gephyrocapsa (Coccolithophorales) in the Plio-Pleistocene of the Timor Trough. Mem. Sci. Geol., 34:453-464.

Pujos-Lamy, A., 1977a. Emiliania et Gephyrocapsa (Nannoplancton calcaire): biometrie et intêret biostratigraphique dans le Pleistocène supérieur marin des Açores. Rev. Esp. Micropaleontol., 9:69-84.

, 1977b. Essai d'établissement d'une biostratigraphie du nannoplancton calcaire dans le Pleistocène de l'Atlantique Nord-oriental. Boreas, 6:323-331.

Rio, D., 1982. The fossil distribution of coccolithophore genus Gephyrocapsa Kamptner and related Plio-Pleistocene chronostratigraphic problems. In Prell, W.L., Gardner, J.V., et al., Init. Repts. DSDP, 68: Washington (U.S. Govt. Printing Office), 325-343.

Rio, D., Fornaciari, E., and Raffi, I., 1990. Late Oligocene through early Pleistocene calcareous nannofossils from western equatorial Indian Ocean (Leg 115). In Duncan, R.A., Backman, J., Peterson, L.C., et al., Proc. ODP, Sci. Results, 115: College Station, TX (Ocean Drilling Program), 175-235.

Robinson, G.P., 1969. The Geology of North Santo. New Hebrides Geol. Surv. Rep., 1-77.
Roth, P.H., and Berger, W.H., 1975. Distribution and dissolution of coccoliths in the south and certral Pacific. In Sliter, W.V.. Bé, A.W.H., and Berger, W.H. (Eds.), Dissolution of Deep-Sea Carbonates. Spec. Publ. Cushman Found. Foraminiferal Res., 13:87-113.

Samtleben, C., 1978. Pliocene-Pleistocene coccolith assemblages from the Sierra Leone Rise, Site 366, Leg 41. In Lancelot, Y., Seibold, E., et al., Init. Repts. DSDP, 41: Washington (U.S. Govt. Printing Office), 496. (Abstract) 1980. Die Evolution der Coccolithophoriden-Gattung Gephyrocapsa nach Befunden im Atlantik. Palaontol. Z., 54:91-127.

Sato, T., Kameo, K., and Takayama, T., 1991. Coccolith biostratigraphy of the Arabian Sea. In Prell, W.L., Niitsuma, N., et al., Proc. ODP, Sci. Results, 117: College Station, TX (Ocean Drilling Program), 37-54.

Shafik, S., 1975. Nannofossil biostratigraphy of the southwest Pacific, Deep Sea Drilling Project Leg, 30. In Andrews, J.E., Packham, G., et al., Init. Repts. DSDP, 30: Washington (U.S. Govt. Printing Office), 549-598.

Shipboard Scientific Party, 1975. Site 286. In Andrews, J.E., Packham, G., et al., Init. Repts. DSDP, 30: Washington (U.S. Govt. Printing Office), 69-131.

Takayama, T., 1970. The Pliocene-Pleistocene boundary in the Lamont Core V-21-98 and at Le Castella, Southern Italy. J. Mar. Geol., 6:70-77.

Taylor, F.W., 1992. Quaternary vertical tectonics of the central New Hebrides Island Arc. In Collot, J.-Y., Greene, H.G., Stokking, L.B., et al., Proc. ODP, Init. Repts., 134: College Station, TX (Ocean Drilling Program), 33-42.

Thierstein, H.R., Geitzenauer, K.R., Molfino, B., and Shackleton, N.J., 1977. Global synchroneity of late Quaternary coccolith datum levels: validation by oxygen isotopes. Geology, 5:400-404.

Wei, W., and Wise, S.W., Jr., 1989. Paleogene calcareous nannofossil magnetobiochronology: results from South Atlantic DSDP Site 516. Mar. Micropaleontol., 14:119-152.

Weissel, J.K., Watts, A.B., and Lapouille, A., 1982. Evidence for late Paleocene to late Eocene sea floor in the southern New Hebrides Basin. Tectonophysics, 87:243-251.

Date of initial receipt: 20 May 1992

Date of acceptance: 8 September 1993

Ms 134SR-009 

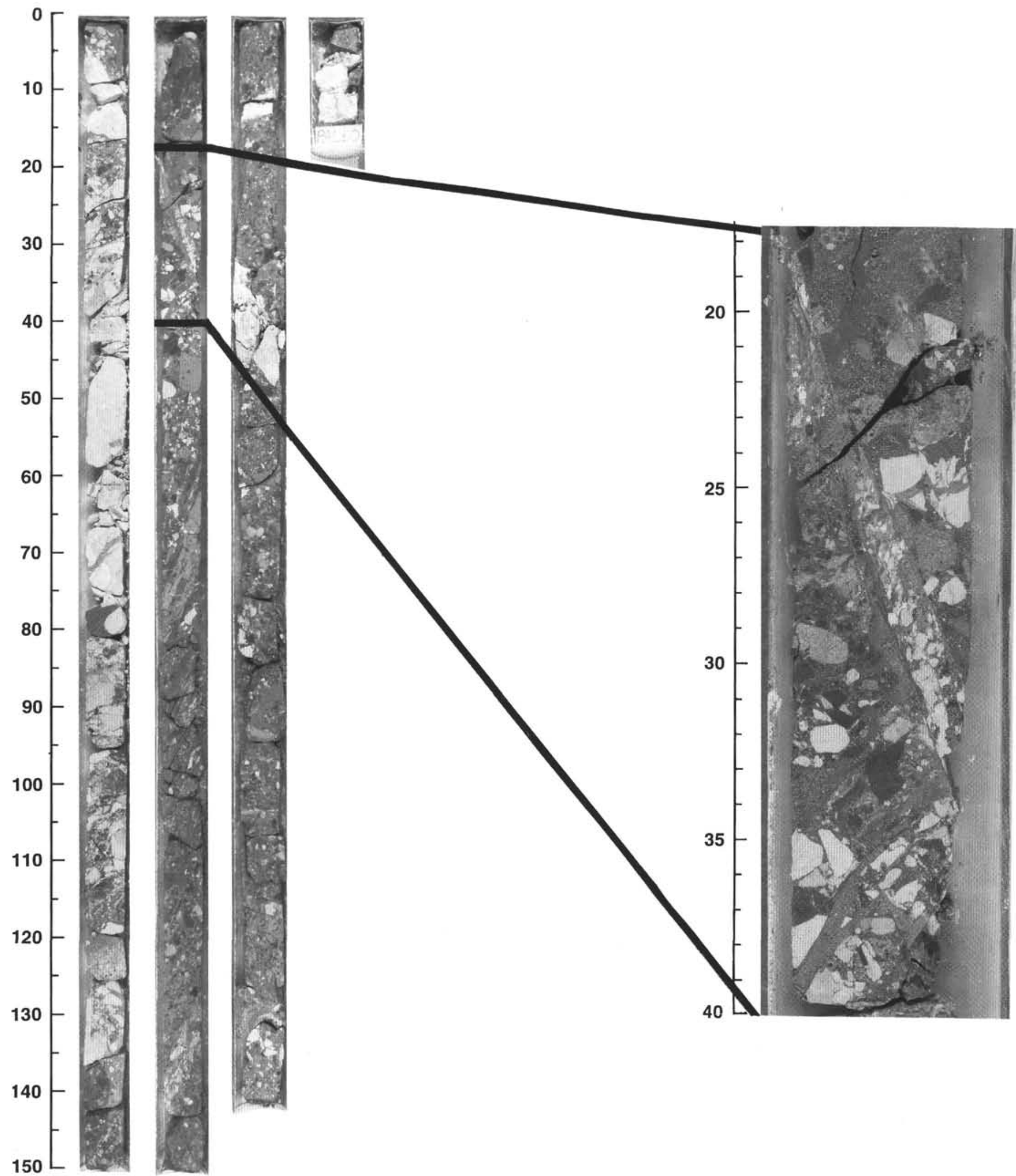

Figure 19. Photograph of the shear zone within sedimentary breccia in Core 134-829A-21R. 


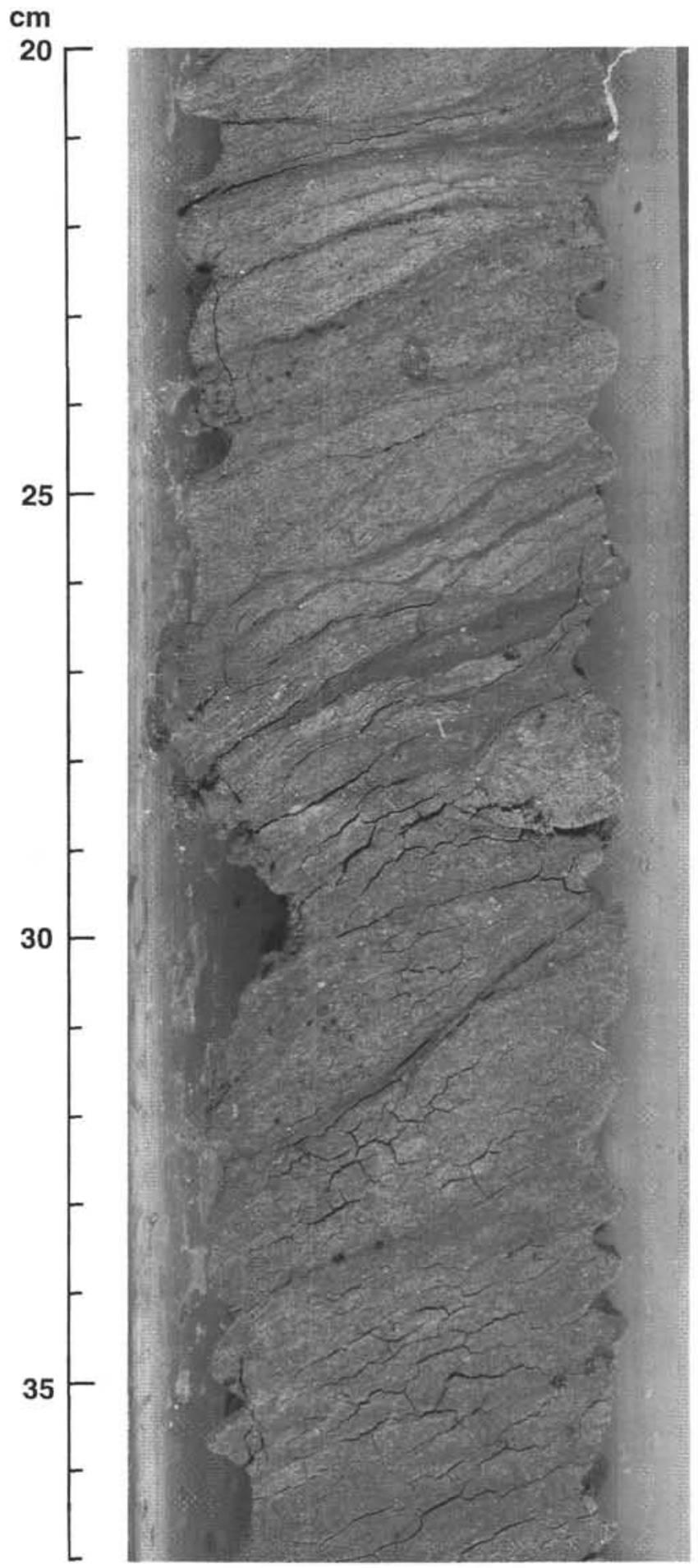

Figure 20. Photograph of planar fabric in the shear zone in Section 134-829A$51 \mathrm{R}-1,20-37 \mathrm{~cm}$. 


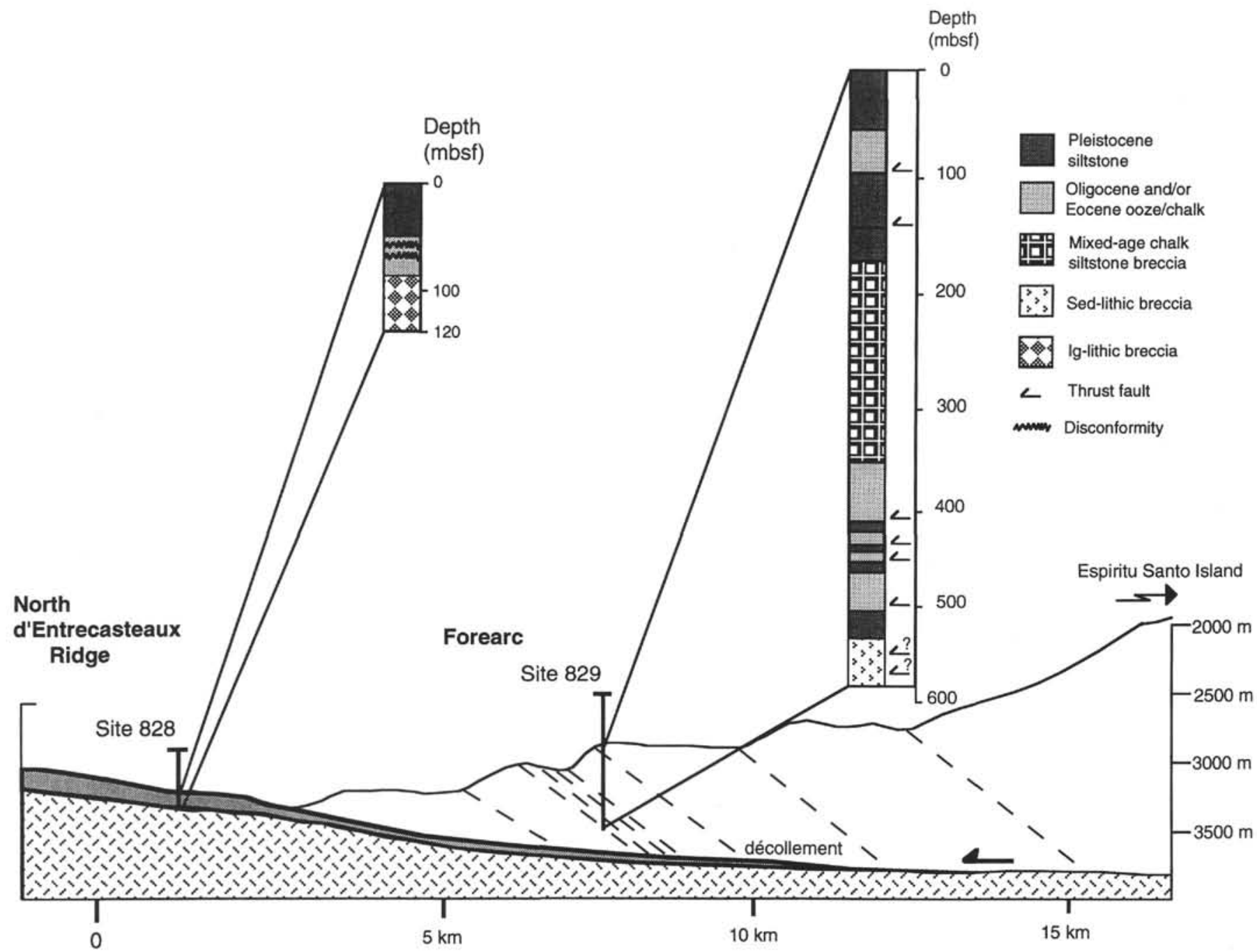

Figure 21. Schematic cross section of the accretionary complex adjacent to Espiritu Santo Island, New Hebrides Island Arc. Fault angles and lithologies are generalized. Lithologies are consistent with ODP nomenclature: sed-lithic breccia (breccia that contains clasts or grains of clastic rock), ig-lithic breccia (breccia that contains igneous rock fragments). Vertical exaggeration $=2.0$. 


\section{APPENDIX A}

\section{TAXONOMIC DISCUSSION, METHODOLOGY, AND RATIONALE FOR DELINEATING CERTAIN BIOSTRATIGRAPHIC DATUMS}

To clarify the morphologic concepts of taxa used in this paper for biostratigraphy, some of the more problematic species are discussed. Because the sediment reworking and shearing evident in some cored intervals from Leg 134 increase the likelihood of displaced nannofossil specimens, the biostratigraphy reflects a high degree of interpretation. For this reason a brief discussion of the placement of certain datums is also presented. The placement of all datums relative to a magnetostratigraphic standard is found in Figure 2 and Table 1.

\section{Emiliania huxleyi (Lohmann, 1902) Hay and Mohler in Hay et al. (1967)}

The first occurrence of $E$. huxleyi is difficult to recognize even under ideal circumstances. Owing to its small size $(2.5-5 \mu \mathrm{m})$, its propensity for dissolution relative to the coexisting gephyrocapsids (McIntyre and McIntyre, 1968; Roth and Berger, 1975; Thierstein et al., 1977), and the rarity of E. huxleyi near its first occurrence in oxygen isotope Stage 8 (Thierstein et al., 1977), the first occurrence of $E$. huxleyi is usually difficult to determine.

Because the Leg 134 samples throughout the Pleistocene were observed under a magnification of approximately $\times 1560$ and the preservation is excellent in all but one site, the identification of individual specimens of $E$. huxleyi was not difficult. High quantities of volcanic silt deposited during the late Pleistocene preserved the nannofossils extraordinarily well. Well-preserved $E$. huxleyi possess a clearly discernable ring of I-bars, which appears as a faint halo around the proximal shield in crossed-polarized light (PI. 2, Fig. 1). In addition to the excellent preservation of $E$. huxleyi, the dissolution prone nannofossils Holodiscolithus macroporous, Discosphaera tubifer, syracosphaerides, and Rhabdosphaera claviger (PI. 3, Fig. 5) are all well preserved, suggesting that selective dissolution has not taken place.

Although placement of the FAD of $E$. huxleyi was not hindered by poor preservation, error due to the species' low abundance near its inception is a concern (Thierstein et al., 1977). To approach this problem, counts of 300 specimens were made from all samples at Site 828A using a Zeiss light microscope at a magnification of approximately $\times 1560$. The results show a trend similar to those recorded by Thierstein et al. (1977), in which the abundance of $E$. huxleyi decreases from its acme in the latest Pleistocene to sparse and rare abundances with increasing depth downhole (Table 2). To verify the placement of this datum, 400 specimens per sample were counted in the SEM over the interval suspected to contain the first $E$. huxleyi (PI. 2, Fig. 3) specimens. No specimens of $E$. huxleyi were recorded below Sample 134-828A-6H-5, 36- $37 \mathrm{~cm}$. Several coccoliths that possessed the I-bar structure in the distal shield and lacked the central cross-bar indicative of a gephyrocapsid were seen below this sample; however, these "questionable" specimens were all smaller than $2 \mu \mathrm{m}$ and were, therefore, interpreted to be broken specimens of Gephyrocapsa protohuxleyi (Pl. 2, Figs. 4, 7, and 8).

Samples from Hole 830 were also studied in the SEM using the methods mentioned previously. Results were identical to its placement in the light microscope. Because both holes in which dual counting methods were used resulted in identical conclusions as to the placement of the FAD of E. huxleyi, the more expensive and time-consuming method involving the SEM was abandoned for the remaining sites.

\section{Pseudoemiliania lacunosa (Kamptner, 1963) Gartner (1969)}

Pseudoemiliania lacunosa (Pl. 3, Fig. 4) is used biostratigraphically as a last-appearance datum. Given the presence of reworked $P$. lacunosa throughout even the youngest Pleistocene (CN15) sediments at all sites, the use of $P$. lacunosa as a reliable datum must be considered tenuous. In order to confirm an LAD of $P$. lacunosa, counts of 300 specimens per slide were made on the light microscope using the same procedures described earlier for the $E$. huxleyi counts. The results show a significant change in abundance of $P$. lacunos $a$ in Sample 134-828A-7H-5, 59-60 cm, (58.49 mbsf) (Fig. 12 and Table 2). Owing to this shift in abundance from sparse to common, it is believed that $P$. lacunosa here is no longer simply a product of reworking. The lack of significant changes in the abundances of reworked discoasters further supports the interpretation that at least some of the $P$. lacunosa specimens are in situ. This conclusion does not rule out the possibility that the true LAD of $P$. lacunosa might lie slightly above its placement in this hole. If the abundance of $P$. lacunosa waned significantly prior to its extinction, the abundance signal recorded from this hole would mark a natural fluctuation in abundance that occurs prior to the true extinction of $P$. lacunosa. Minor reworking of $P$. lacunosa throughout this interval could, therefore, obscure its true extinction because some specimens of $P$. lacunosa would always be present. In the absence of nearby reference sections providing comparative abundance profiles unaffected by reworking, the LAD of $P$. lacunosa is tentatively placed at the point of significant abundance change.

Placing the LAD of $P$. lacunosa at its shift in abundance, irrespective of its final disappearance, is not without precedent. Using cores from the Ontong Java plateau, Thierstein et al. (1977) described a trend for $P$. lacunosa in which relative abundances decrease below $1 \%$ of the population prior to extinction. Using the midpoint of this decrease in the interval between $1 \%$ and $0 \%$ relative abundance, Thierstein et al. (1977) suggested that the most biostratigraphically useful point for the consistent placement for the LAD occurs just prior to extinction, which is consistently positioned within oxygen isotope stage 12 at $0.46 \mathrm{Ma}$. Using cores from the Tyrrhenian Sea, Rio et al. (1990) indicated an abundance signature for $P$. lacunos $a$ that compares well with that proposed by Thierstein et al. (1977). It is believed that despite minor reworking, the abundance increase of $P$. lacunosa at Sample 134-828A-7H-5, 59-60 cm, represents a reasonable approximation of the LAD datum of $P$. lacunosa as defined by Thierstein et al. (1977).

\section{Gephyrocapsids}

Numerous researchers have studied the taxonomy and biostratigraphic utility of the genus Gephyrocapsa (Bukry, 1973; Duplessy et al., 1975; Gartner, 1972, 1977; Matsuoka and Okada, 1989, 1990; Proto Decima and Masotti, 1981; Pujos-Lamy, 1977 a,b; Rio, 1982; Samtleben, 1978, 1980). A high degree of variability exists in the species concept of this genus, which makes widespread correlation difficult. The two species of Gephyrocapsa most commonly referred to in biostratigraphic literature are G. oceanica Kamptner, 1943 and G. caribbeanica Boudreaux and Hay, 1969. Although these two species are widely used as zonal markers for the Pleistocene in the zonal scheme of Okada and Bukry (1980), a consensus on the size limits and morphologic variation allowed by the holotypes has not been reached. Several of the most recent efforts to clarify the stratigraphic ranges of the gephyrocapsids indicate that the group displays a definite time-progressive change in morphology throughout the upper Pliocene and Pleistocene, and that this change in size is both consistent and observable in the light microscope (Matsuoka and Okada, 1989, 1990; Rio, 1982).

Concentrating on biostratigraphic applications, Rio (1982), subdivided the gephyrocapsid group according to size, ignoring variations in central bar angle, central area proportions, and placolith thickness. Medium Gephyrocapsa in this scheme are defined as all forms between $3.5 \mu \mathrm{m}$ and $5.5 \mu \mathrm{m}$. This approach is particularly appealing for use in biostratigraphy because the scheme can easily be applied to light microscopy, and size determinations leave no room for subjective interpretation.

Matsuoka and Okada (1990) suggested that because many gephyrocapsids fall within the 3.0 to $4.0 \mu \mathrm{m}$ range, the minimal size for medium Gephyrocapsa should be placed at $4.0 \mu \mathrm{m}$. In their revisions of the diagnostic parameters, both $G$. oceanica and $G$. caribbeanica overlap within this size range but are distinguished by morphologic features such as the angle of the bar and size of the central openings.

Several factors were considered in deciding upon the type of zonal scheme to be used to study the Pleistocene. Because the primary purpose of this study is to elucidate the biostratigraphy, a scheme providing the highest degree of time resolution is desirable. However, the reworking documented within the Pleistocene coupled with the quantity of samples to be analyzed argues for the simplest, most reproducible zonation scheme. For these reasons the method of distinguishing gephyrocapsids based exclusively upon size was chosen for this study. The lower limit for medium gephyrocapsids is placed at $4.0 \mu \mathrm{m}$ and the upper limit at $5.5 \mu \mathrm{m}$. Both $G$. oceanica and $G$. caribbeanica fall within this size range. Because no distinctions are made as to the bar angle or central opening size, G. oceanica and $G$. caribbeanica are not distinguished from each other in this study. Instead, all species falling within the size range from 4.0 to $5.5 \mu \mathrm{m}$ are called G. oceanica (PI. 1, Fig. 5) irrespective of minor morphological differences. Small gephyrocapsids are classified as forms smaller than 3.5 $\mu \mathrm{m}$, and large gephyrocapsids are those greater than $5.5 \mu \mathrm{m}$, as proposed by Rio et al. (1990).

\section{Sphenolithus distentus s.l.}

The Sphenolithus lineage provides the basis for the subdivision of the middle and upper Oligocene. The distinction between Sphenolithus distentus (Pl. 2, Fig. 5) and Sphenolithus predistentus (Pl. 2, Fig. 2) is based primarily 
on the position of the extinction lines of the apical spine and proximal column viewed under polarized light. Although the FAD's of both of these species are routinely used as biostratigraphic markers, Wei and Wise (1989) showed that these datums are highly variable at sites with reliable magnetostratigraphy. Their study suggests that either a high degree of interspecific variation has resulted in misidentification of the species, or the species are not globally synchronous. Recent studies by Okada (1990) and Fornaciari et al. (1990) suggest that the former hypothesis may be correct because they have recognized a species resembling $S$. distentus that ranges into the lower Oligocene. Both studies indicate that this yet unnamed species (referred to as Sphenolithus sp. aff. $S$. distentus and Sphenolithus sp. 1) does not overlap with $S$. distentus. Inconsistencies in the placement of $S$. distentus in the past might be the result of differing species concepts in which some researchers include the older sphenolith within $S$. distentus whereas others exclude it.

A sphenolith resembling $S$. distentus was recorded in rare quantities at Hole 828B. Referred to here as Sphenolithus distentus sl. (Pl. 2, Fig. 6), this is probably the Sphenolithus sp. aff. S. distentus of Okada (1990) and Sphenolithus sp. 1 of Fornaciari et al. (1990).

\section{Calcidiscus macintyrei (Bukry and Bramlette, 1969) Loeblich and Tappan, 1978}

The distinction between Calcidiscus macintyrei and C. leptoporous (PI. 3, Fig. 2) in this study is based entirely upon the diameter of the distal shield. A minimum size of $11 \mu \mathrm{m}$ for C. macintyrei is adopted from Rio et al. (1990).

\section{Reticulofenestrids}

The minimum size for Reticulofenestra pseudoumbilica used in this study is $7 \mu \mathrm{m}$ (Rio et al., 1990). Reticulofenestrids between 7 and $5 \mu \mathrm{m}$ are termed Reticulofenestra sp., and all reticulofenestrids smaller than $5 \mu \mathrm{m}$ are grouped together as Reticulofenestra $\mathrm{sp}$. $(<5 \mu \mathrm{m})$. For the Eocene and Oligocene marker $R$. umbilica, a minimum size of $14 \mu \mathrm{m}$ is adopted from Backman and Hermelin (1986).

\section{APPENDIX B}

\section{ALPHABETIC LIST OF TAXA}

Amaurolithus Gartner and Bukry (1975)

A. amplificus (Bukry and Percival, 1971) Gartner and Bukry (1975)

A. delicatus Gartner and Bukry (1975)

A. primus (Bukry and Percival, 1971) Gartner and Bukry (1975)

A. tricorniculatus (Gartner, 1967) Gartner and Bukry (1975)

Blackites Hay and Towe (1962)

Braarudosphaera Deflandre (1947)

B. biglowii (Gran and Braarud, 1935) Deflandre (1947)

Bramletteius Gartner (1969a)

B. serraculoides Gartner (1969a)

Calcidiscus Kamptner (1950)

C. kingii (Roth, 1970) Loeblich and Tappan (1978)

C. leptoporus (Murray and Blackman, 1898) Loeblich and Tappan (1978)

C. macintyrei (Bukry and Bramlette, 1969b) Loeblich and Tappan (1978)

C. protoannulus (Gartner, 1971) Loeblich and Tappan (1978)

Catinaster Martini and Bramlette (1963)

C. calyculus Martini and Bramlette (1963)

C. coalitus Martini and Bramlette (1963)

C. umbrellus Bukry (1971b)

Ceratolithus Kamptner (1950)

C. acutus Gartner and Bukry (1974)

C. armatus Müller (1974)

C. cristatus Kamptner (1950)

C. rugosus Bukry and Bramlette (1968)

C. separatus Bukry (1979)

C. simplex Bukry (1979)

C. telesmus Norris (1965)

Chiasmolithus Hay, Mohler, and Wade (1966)

C. altus Bukry and Percival (1971)

C. grandis (Bramlette and Riedel, 1954) Radomski (1968)

C. oamaruensis (Deflandre, 1954) Hay, Mohler, and Wade (1966)

Clausicoccus Prins (1979)

C. fenestratus (Deflandre and Fert, 1954) Prins (1979)

Coccolithus Schwarz (1894)
C. pelagicus (Wallich, 1877) Schiller (1930)

Coronocyclus Hay, Mohler, and Wade (1966)

C. nitescens (Kamptner, 1963) Bramlette and Wilcoxon (1967)

Cribrocentrum Perch-Nielsen (1971d)

C. reticulatum (Gartner and Smith, 1967) Perch-Neilsen (1971d)

Cruciplacolithus Hay and Mohler in Hay et al. (1967)

C. cruciformis (Hay and Towe, 1962) Roth (1970)

Cyclicargolithus Bukry (1971a)

C. abisectus (Müller, 1970) Wise (1973)

C. floridanus (Roth and Hay in Hay et al., 1967) Bukry (1971a)

Dictycoccites Black (1967)

D. bisectus (Hay, Mohler, and Wade, 1967) Bukry and Percival (1971)

D. productus (Kamptner, 1963) Backman (1980)

D. scrippsae Bukry and Percival (1971)

Discoaster Tan (1927)

D. adamanteus Bramlette and Wilcoxon (1967)

D. assymetricus Gartner (1969c)

D. aulakos Gartner (1967)

D. barbadiensis Tan (1927)

D. berggrenii Bukry (1971b)

D. binodosus Martini (1958)

D. bramlettei Bukry and Percival (1971)

D. brouweri (Tan, 1927) emend. Bramlette and Riedel (1954)

D. calcaris Gartner (1967)

D. challengeri Bramlette and Riedel (1954)

D. deflanrei Bramlette and Reidel (1954)

D. intercalaris Bukry (1971a)

D. lenticularis Bramlette and Sullivan (1961)

D. lodoensis Bramlette and Riedel (1954)

D. neorectus Bukry (1971a)

D. nodifer (Bramlette and Riedel, 1954) Bukry (1973c)

D. pansus (Bukry and Percival, 1971) Bukry (1973c)

D. pentaradiatus (Tan, 1927) emend. Bramlette and Riedel (1954)

D. quadramus Bukry (1973d)

D. quinqueramus Gartner (1969c)

D. saipanensis Bramlette and Riedel (1954)

D. septemradiatus (Klumpp, 1953) Martini (1958)

D. surculus Martini and Bramlette (1963)

D. tamalis Kamptner (1967)

D. tanii Bramlette and Riedel (1954)

D. triradiatus Tan (1927)

D. variabilis Martini and Bramlette (1963)

Discosphaera Haeckel (1894)

D. tubifer (Murray and Blackman, 1898) Ostenfeld (1900)

Emiliania Hay and Mohler in Hay et al. (1967)

E. huxleyi (Lohmann, 1902) Hay and Mohler in Hay et al. (1967)

Ericsonia Black (1964)

Ericsonia formosa (Kamptner, 1963) Haq (1971)

Gephyrocapsa Kamptner (1943)

G. oceanica Kamptner (1943)

G. protohuxleyi McIntyre (1970)

Hayaster Bukry (1973d)

H. perplexus (Bramlette and Reidel, 1954) Bukry (1973d)

Helicosphaera Kamptner (1954)

H. bramlettei Müller (1970)

H. compacta Bramlette and Wilcoxon (1967)

H. euphratis Haq (1966)

H. granulate Bukry and Percival (1971)

$H$. inversa Gartner (1980)

H. kamptneri Hay and Mohler in Hay et al. (1967)

$H$. perch-nielseniae Haq (1971)

$H$. recta Haq (1966)

H. selli Bukry and Bramlette (1969b)

Holodiscolithus Roth (1970)

H. macroporus (Deflandre in Deflandre and Fert, 1954) Roth (1970)

Isthmolithus Deflandre (1954)

I. recurvus Deflandre (1954)

Lanternithus Stradner (1962)

L. minutus Stradner (1962)

Markalius Bramlette and Martini (1964)

M. inversus (Deflandre in Deflandre and Fert, 1954) Bramlette and Martini (1964)

Micrantholithus Deflandre in Deflandre and Fert (1954)

Neochiatstozygus Perch-Nielsen (1971c) 
Oolithotus Reinhardt in Cohen and Reinhardt (1968)

O. fragilis (Lohmann, 1912) Martini and Muller (1972)

Pedinocyclus Bukry and Bramlette (1971)

P. larvalis (Bukry and Bramlette, 1969b) Loeblich and Tappan (1973)

Pontosphaera Lohmann (1902)

P. discopora Schiller (1925)

P. distincta (Bramlette and Sullivan, 1961) Roth and Thierstein (1972)

P. indooceanica Cepek (1973)

P. japonica (Takayama, 1967) Nishida (1971)

P. multipora (Kamptner, 1948) Roth (1970)

Pseudoemiliania Gartner (1969c)

P. lacunosa (Kamptner, 1963) Gartner (1969c)

Reticulofenestra Hay, Mohler, and Wade (1966)

R. callidus (Perch-Nielsen, 1971d) Bybell (1975)

R. hampdenensis Edwards (1973a)

R. pseudoumbilica (Gartner, 1967) Gartner (1969c)

R. umbilica (Levin, 1965) Martini and Ritzkowski (1968)

Rhabdosphaera Haeckel (1894)

R. claviger Murray and Blackman (1898)

R. procera Martini (1969)

Scapholithus Deflandre in Deflandre and Fert (1954)

S. fossilis Deflandre in Deflandre and Fert (1954)

Scyphosphaera Lohmann (1902)

Semihololithus Perch-Nielsen (1971b)

S. sp. Perch-Nielsen (1971b)

Sphenolithus Deflandre in Grassé (1952)

S. abies Deflandre in Deflandre and Fert (1954)
S. ciperoensis Bramlette and Wilcoxon (1967)

S. conicus Bukry (1971a)

S. delphix Bukry (1973c)

S. dissimilis Bukry and Percival (1971)

S. distentus (Martini, 1965) Bramlette and Wilcoxon (1967)

S. heteromorphus Deflandre (1953)

S. moriformis (Bronnimann and Stradner, 1960) Bramlette and Wilcoxon (1967)

S. neoabies Bukry and Bramlette (1969a)

S. predistentus Bramlette and Wilcoxon (1967)

S. pseudoradians Bramlette and Wilcoxon (1967)

S. radians Deflandre in Grassé (1952)

S. tribulosus Roth (1970)

Syracosphaera Lohmann (1902)

S. pulchra Lohmann (1902)

S. clava Hay and Beaudry (1973)

Thoracosphaera Kamptner (1927)

Triquetrorhabdulus Martini (1965)

T. carinatus Martini (1965)

T. rugosus Bramlette and Wilcoxon (1967)

Umbellosphaera Lohmann (1902)

U. irregularis Paasche in Markali and Paasche (1955)

Umbilicosphaera Lohmann (1902)

U. angustiforamen Okada and McIntyre (1977)

U. mirabilis Lohmann (1902)

Zygrhablithus Deflandre (1959)

Z. bijugatus (Deflandre in Deflandre and Fert, 1954) Deflandre (1959) 
APPENDIX C

LIST OF CLASTS

\begin{tabular}{|c|c|c|c|c|}
\hline $\begin{array}{l}\text { Core, section, } \\
\text { interval }(\mathrm{cm})\end{array}$ & Zone & Age & Lithology & Material \\
\hline \multicolumn{5}{|l|}{$134-829 \mathrm{~A}-$} \\
\hline $19 \mathrm{R}-4,130$ & CN4 & early Miocene & Chalk & Clast \\
\hline $19 \mathrm{R}-5,40$ & $\mathrm{CN} 14$ & early/middle Pleistocene & Vitric siltstone & Clast \\
\hline $19 R-5,67-68$ & $\mathrm{CN} 14$ & early/middle Pleistocene & Vitric siltstone & Clast \\
\hline $19 \mathrm{R}-5,86$ & $\mathrm{CN} 4$ & early Miocene & Chalk & Clast \\
\hline $19 \mathrm{R}-5,104-105$ & $\mathrm{CN} 4$ & early Miocene & Chalk & Clast \\
\hline $19 \mathrm{R}-5,131-132$ & $\mathrm{CN} 14$ & early/middle Pleistocene & Vitric siltstone & Clast \\
\hline $20 \mathrm{R}-1,45-46$ & $\mathrm{CN} 4$ and $\mathrm{CN} 14$ & early Miocene and Pleistocene & Mixed & Clast \\
\hline $20 \mathrm{R}-1,135-136$ & $\mathrm{CN} 4$ & early Miocene & Chalk & Clast \\
\hline $20 \mathrm{R}-2,62-63$ & $\mathrm{CN} 4$ & early Miocene & Chalk & Clast \\
\hline $20 \mathrm{R}-2,135-136$ & $\mathrm{CN} 4$ & early Miocene & Chalk & Clast \\
\hline $20 \mathrm{R}-2,75-76$ & $\mathrm{CN} 4$ and $\mathrm{CN} 14$ & early Miocene and Pleistocene & Mixed & Matrix \\
\hline $21 R-1,70-71$ & $\mathrm{CN} 1 / \mathrm{CP} 19$ & early Miocene or late Oligocene & Chalk & Clast \\
\hline $21 \mathrm{R}-1,75-76$ & $\mathrm{CN1}$ and $\mathrm{CN} 14$ & early Miocene and Plestocene & Mixed & Matrix \\
\hline $21 R-2,73-74$ & $\mathrm{CP} 19$ and $\mathrm{CN} 1$ & late Oligocene and Pleistocene & Mixed & Clay matrix \\
\hline $22 \mathrm{R}-1,7-8$ & $\mathrm{CN} 1 / \mathrm{CP} 19$ & early Miocene or late Oligocene & Chalk & Clast \\
\hline $22 \mathrm{R}-1,16-17$ & $\mathrm{CP} 19$ and $\mathrm{CN} 1$ & late Oligocene and Pleistocene & Mixed & Clast \\
\hline $23 \mathrm{R}-1,46-47$ & $\mathrm{CN} 1 / \mathrm{CP} 19$ & early Miocene or late Oligocene & Chalk & Clast \\
\hline $23 \mathrm{R}-2,19-20$ & $\mathrm{CN} 1 / \mathrm{CP} 19$ & early Miocene or late Oligocene & Chalk & Clast \\
\hline $24 \mathrm{R}-1,45-46$ & $\mathrm{CN} 1 / \mathrm{CP} 19$ & early Miocene or late Oligocene & Chalk & Clast \\
\hline $24 \mathrm{R}-2,21-22$ & $\mathrm{CN} 1 / \mathrm{CP} 19$ & early Miocene or late Oligocene & Chalk & Clast \\
\hline $25 \mathrm{R}-1,20-21$ & $\mathrm{CN} 1 / \mathrm{CP} 19$ & early Miocene or late Oligocene & Chalk & Clast? \\
\hline $26 \mathrm{R}-1,14-15$ & CN14? & early/middle Pleistocene & Vitric siltstone & Clast \\
\hline $26 \mathrm{R}-1.55-56$ & $\mathrm{CN} 1 / \mathrm{CP} 19$ & early Miocene or late Oligocene & Chalk & Clast \\
\hline $30 \mathrm{R}-1,31-32$ & $\mathrm{CN} 1 / \mathrm{CP} 19$ & early Miocene or late Oligocene & Chalk & Clast \\
\hline $31 \mathrm{R}-1.107-108$ & $\mathrm{CN} 1 / \mathrm{CP} 19$ & early Miocene or late Oligocene & Chalk & Clast \\
\hline $32 \mathrm{R}-1,24-25$ & $\mathrm{CN} 1 / \mathrm{CP} 19$ & early Miocene or late Oligocene & Chalk & Clast \\
\hline $33 \mathrm{R}-1,32-33$ & $\mathrm{CN} 1 / \mathrm{CP} 19$ & early Miocene or late Oligocene & Chalk & Clast \\
\hline $37 \mathrm{R}-1,35-36$ & $\mathrm{CN} 1 / \mathrm{CP} 19$ & early Miocene or late Oligocene & Chalk & Clast? \\
\hline $38 \mathrm{R}-1.28-29$ & $\mathrm{CN} 1 / \mathrm{CP} 19$ & early Miocene or late Oligocene & Chalk & Clast \\
\hline $40 \mathrm{R}-1,10-11$ & $\mathrm{CN} 1 / \mathrm{CP} 19$ & early Miocene or late Oligocene & Chalk & Clast \\
\hline $51 R-2,57-58$ & $\mathrm{CN} 1 / \mathrm{CP} 19$ & early Miocene or late Oligocene & Chalk & Clast \\
\hline $53 \mathrm{R}-2,57-58$ & CN11? & early Pliocene & Chalk & Clast \\
\hline $56 \mathrm{R}-1,132-133$ & CN10C? & early Pliocene & Chalk & Clast \\
\hline $56 \mathrm{R}-1,141-143$ & $?$ & Eocene, Pliocene, and Pleistocene & Mixed & Matrix \\
\hline $56 \mathrm{R}-1,145-146$ & CN11? & early Pliocene & Chalk & Clast \\
\hline $56 \mathrm{R}-2,5-6$ & $\mathrm{CN} 10 \mathrm{C}$ ? & early Pliocene & Chalk & Clast \\
\hline $56 \mathrm{R}-2,105-106$ & CP17/18 & early Pliocene & Chalk & Clast \\
\hline $56 \mathrm{R}-2,64-65$ & $?$ & Eocene, Pliocene, and Pleistocene & Mixed & Matrix \\
\hline $56 \mathrm{R}-1,129-130$ & ? & Eocene, Pliocene, and Pleistocene & Mixed & Matrix \\
\hline \multicolumn{5}{|l|}{$134-827 \mathrm{~B}-$} \\
\hline $5 R-2,42-46$ & $\mathrm{CN} 12 \mathrm{~d}$ & late Pliocene & Vitric siltstone & Clast \\
\hline $5 \mathrm{R}-2,76-79$ & $\mathrm{CN} 13$ & late Pliocene & Vitric siltstone & Clast \\
\hline $5 R-4,28-29$ & $\mathrm{CN} 13$ & late Pliocene & Vitric siltstone & Clast \\
\hline $10 \mathrm{R}-4,150-151$ & CP11 & early Eocene & Chalk & Clast \\
\hline $10 \mathrm{R}-5,18-19$ & $\mathrm{CN} 13$ & late Pliocene & Vitric siltstone & Clast \\
\hline $10 \mathrm{R}-5,41-42$ & CP11 & early Eocene & Chalk & Clast \\
\hline $10 R-5,96-97$ & $\mathrm{CN} 12 \mathrm{~d} / \mathrm{CN} 13$ & late Pliocene & Vitric siltstone & Clast \\
\hline $11 \mathrm{R}-1,16-17$ & CP11 & early Eocene & Chalk & Clast \\
\hline IIR-1, 43-44 & CP12 & middle Eocene & Chalk & Clast \\
\hline $11 R-1,60-61$ & CP12 & middle Eocene & Chalk & Clast \\
\hline $11 \mathrm{R}-1,82-83$ & CP11 & early Eocene & Chalk & Clast \\
\hline $11 \mathrm{R}-1,134-135$ & $\mathrm{CN} 12 \mathrm{~d}$ & late Pliocene & Vitric siltstone & Clast \\
\hline $1 \mathrm{IR}-2,16-17$ & $\mathrm{CN} 12 \mathrm{~d}$ & late Pliocene & Vitric siltstone & Clast \\
\hline $11 \mathrm{R}-2,21-22$ & $\mathrm{CN} 12 \mathrm{~d} / \mathrm{CN} 13$ & late Pliocene & Vitric siltstone & Clast \\
\hline IIR-1, 55-56 & $\mathrm{CN} 14$ & early Pleistocene & Vitric siltstone & Clast \\
\hline $11 \mathrm{R}-2,67-68$ & CP12 & middle Eocene & Chalk & Clast \\
\hline $12 \mathrm{R}-3,54-55$ & $\mathrm{CN} 13$ & late Pliocene & Vitric siltstone & Clast \\
\hline $14 \mathrm{R}-2,62-65$ & $\mathrm{CN} 12 \mathrm{~b}$ & late Pliocene & Vitric siltstone & Clast \\
\hline $14 \mathrm{R}-2,132-135$ & $\mathrm{CN} 12 \mathrm{~b}$ & late Pliocene & Vitric siltstone & Clast \\
\hline $15 R-3,5-6$ & $\mathrm{CN} 13$ & late Pliocene & Vitric siltstone & Clast \\
\hline $16 \mathrm{R}-1,10-11$ & $?$ & $?$ & Chalk & Clast \\
\hline
\end{tabular}




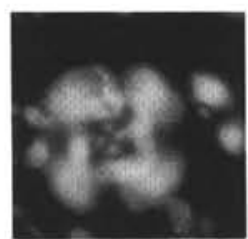

1a

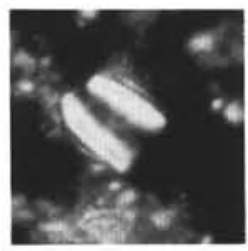

$4 a$

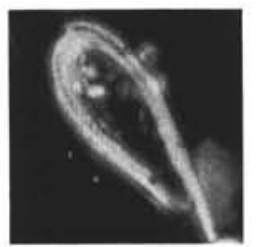

$7 a$

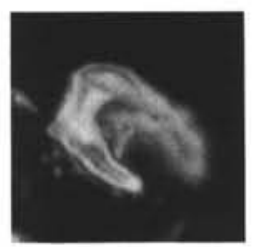

$10 a$

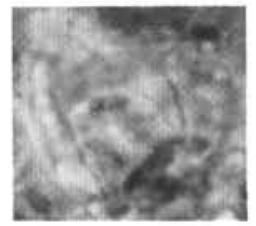

$13 a$

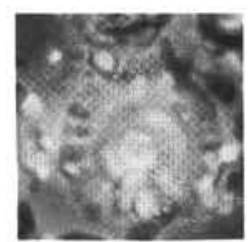

$1 b$

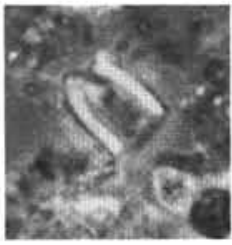

$4 b$

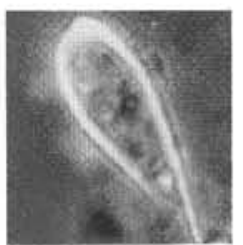

$7 b$

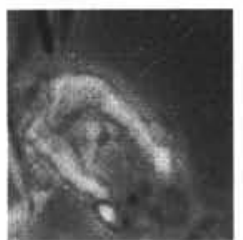

10b

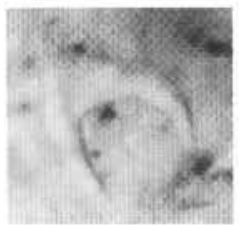

$13 b$

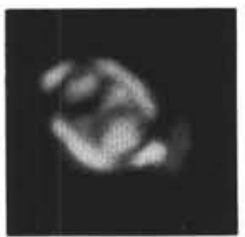

2a

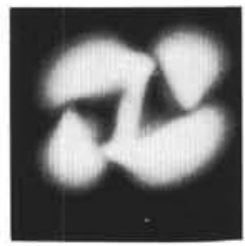

$5 a$

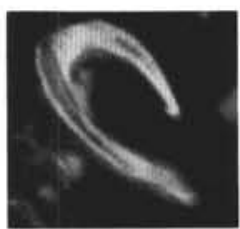

$8 a$

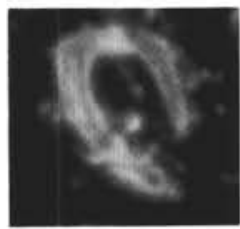

$11 a$

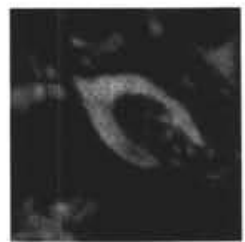

$14 a$

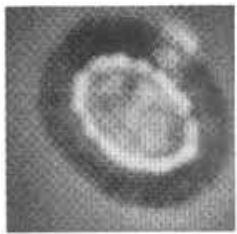

$2 b$

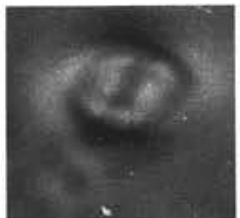

$5 b$

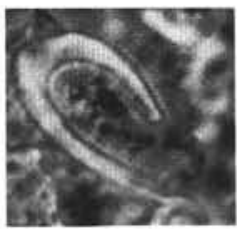

$8 b$

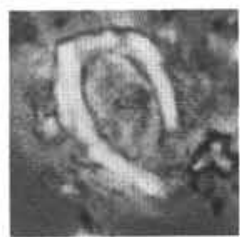

11b

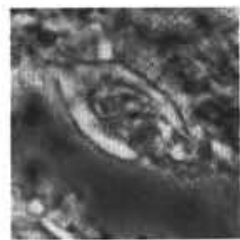

$14 \mathrm{~b}$

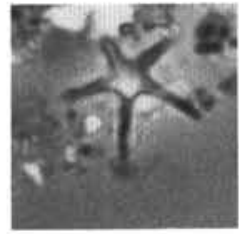

3

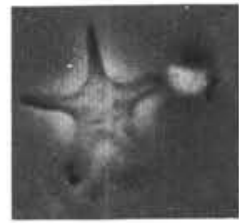

6

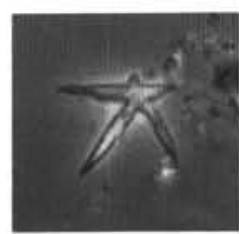

9

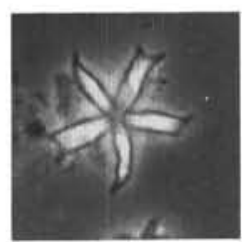

12

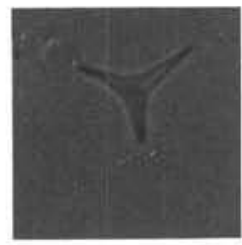

15

Plate 1. 1. $(\times 1600)$ Cribrocentrum reticulatum Gartner and Smith. Sample 134-828B-1R-4, 121-122 cm, (a) cross-nicols, (b) phase contrast. 2. $(\times 4000)$ Clausicoccus fenestratus Deflandre and Fert. Sample 134-828B-1R-4, 121-122 cm, (a) cross-nicols, (b) phase contrast. 3. ( $\times 850)$ Discoaster quinqueramus Gartner. Sample 134-832B-70R-5, 42-44 cm, phase contrast. 4. (×3500) Semihololithus sp.?, Sample 134-832B-70R-5, 42-44 cm, (a) cross-nicols, (b) phase contrast. 5. $(\times 4000)$ Gephyrocapsa oceanica. Kamptner. Sample 134-830A-1H-2, 60-61 cm, (a) cross-nicols, (b) phase contrast. 6. $(\times 850)$ Discoaster berggrenii. Bukry. Sample 134-832B-70R-5, 42-44 cm. 7. (×1200) Ceratolithus telesmus. Norris. Sample 134-830A-1H-1, 60-61 cm, (a) cross-nicols, (b) phase contrast. 8. $(\times 1200)$ Ceratolithus cristatus, Kamptner. Sample 134-832A-7H-1, 108-109 cm, (a) cross-nicols, (b) phase contrast. 9. ( $\times 850)$ Discoaster asymmetricus, Gartner. Sample 134-828A-8R-2,15-16 cm, cross-nicols. 10. $(\times 1300)$ Ceratolithus separatus, Bukry. Sample 134-832B-62R-1, 51-52 cm, (a) cross-nicols, (b) phase contrast. 11. (×1200) Ceratolithus cf. separatus, Bukry. Sample 134-832B-60R-4, 51-52 cm, (a) cross-nicols, (b) phase contrast. 12. $(\times 850)$ Discoaster pentaradiatus, Tan. Sample 134-828A-8R-2, 15-16 cm, cross-nicols. 13. $(\times 1300)$ Amaurolithus amplificus, Bukry and Percival. Sample 134-832B-70R-5, 42-44 cm, (a) phase contrast, (b) plane light. 14. ( $\times 850)$ Ceratolithus armatus, Muller. Sample 134-832B-62R-5, 77-78 cm, (a) cross-nicols, (b) phase contrast. 15. $(\times 850)$ Discoaster triradiatus, Tan. 134-832B-60R-1, 51-52 cm, phase contrast. 


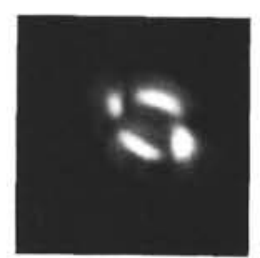

1.

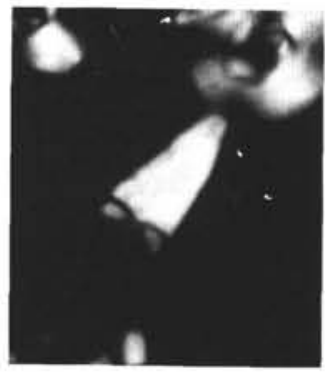

2

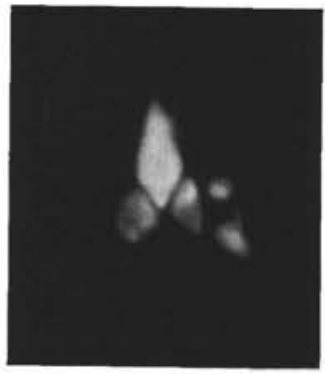

5

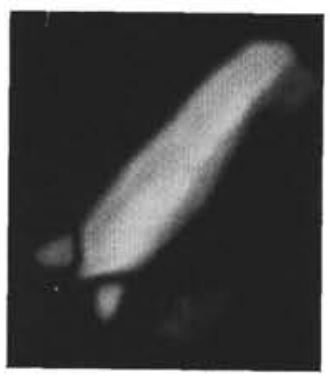

6

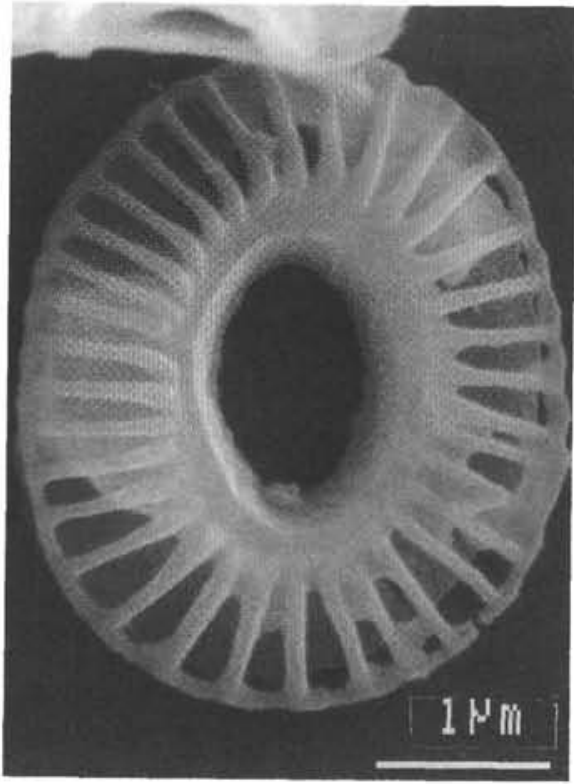

3

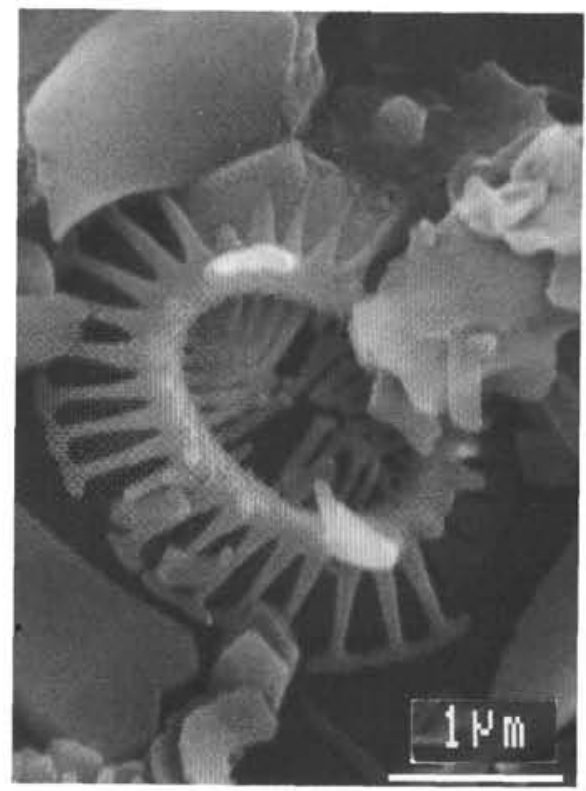

7

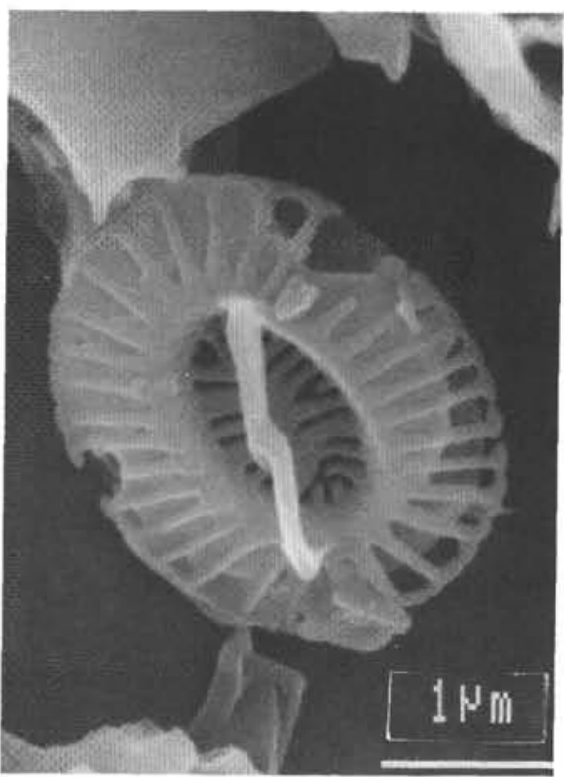

4

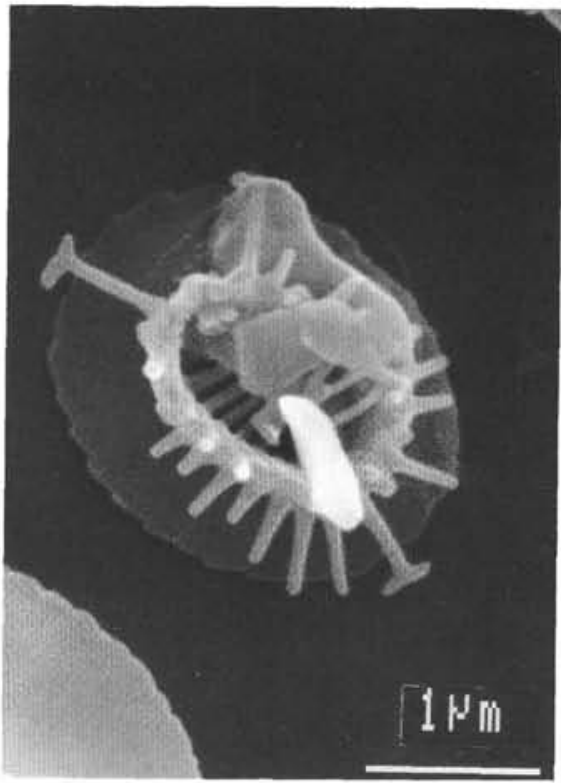

8

Plate 2. 1. $(\times 5000)$ Emiliania huxleyi, Lohmann. Sample $134-830 \mathrm{~A}-1 \mathrm{H}-2,60-61 \mathrm{~cm}$, cross-nicols. 2. $(\times 2400)$ Sphenolithus predistentus, Bramlette and Wilcoxon. Sample 134-828A-9R-4, 89-90 cm, cross-nicols. $(\times 18,000)$ 3. Emiliania huxleyi, Lohmann. Sample 134-830A-2H-6, 30-31 cm, SEM. 4. $(\times 18,000)$ Gephyrocapsa protohuxleyi, McIntyre. Sample 134-828A-7H-2, 101-102 cm, SEM. 5. $(\times 2400)$ Sphenolithus distentus, Martini. Sample 134828A-9R-4, 89-90 cm, cross-nicols. 6. (×3200) Sphenolithus distentus s.l., Sample 134-828B-1R-4, 121-122 cm, cross-nicols. 7. ( $\times 18,000)$ Gephyrocapsa protohuxleyi, McIntyre. Sample 134-828A-7H-2,101-102 cm, SEM. 8. $(\times 18,000)$ Gephyrocapsa protohuxleyi, McIntyre. Sample 134-828A-7H-2, 101-102 $\mathrm{cm}$, SEM 


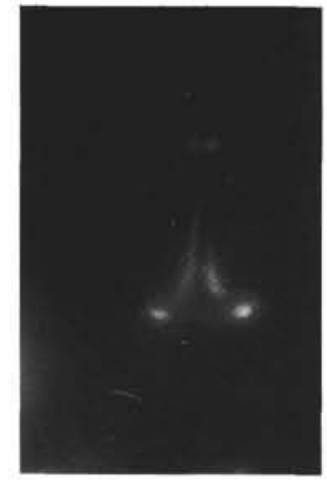

1

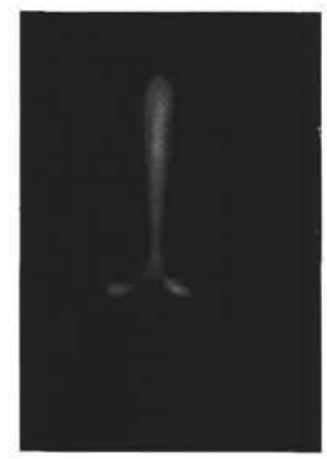

3

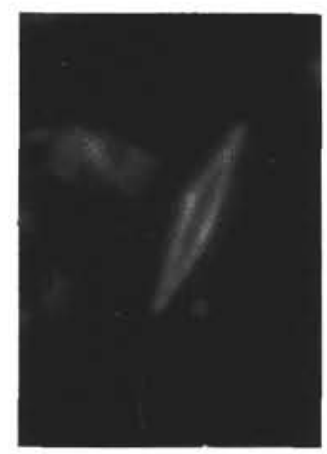

6

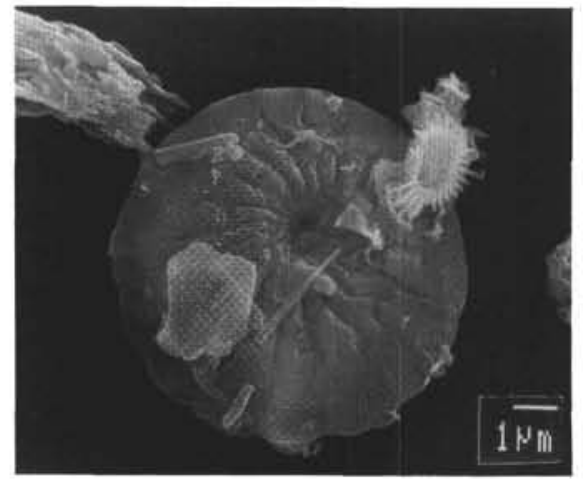

2

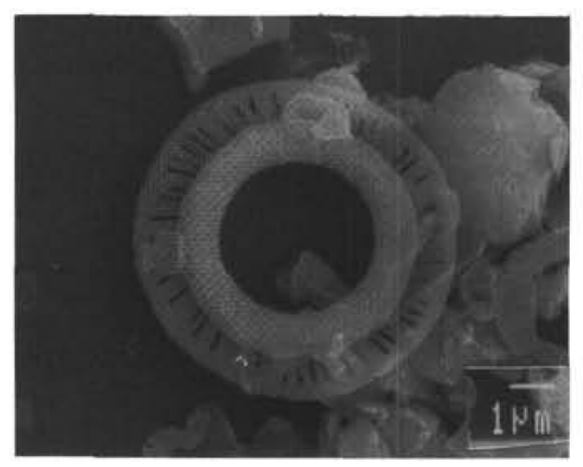

4

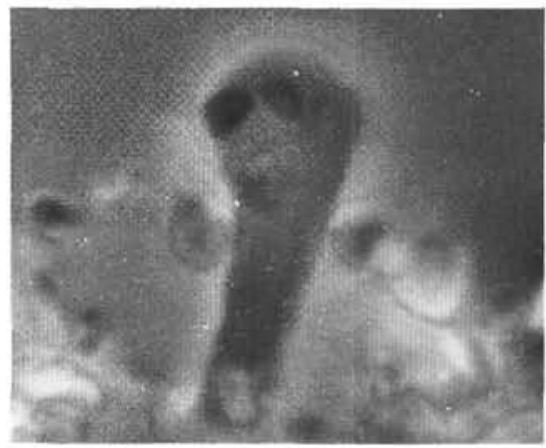

7

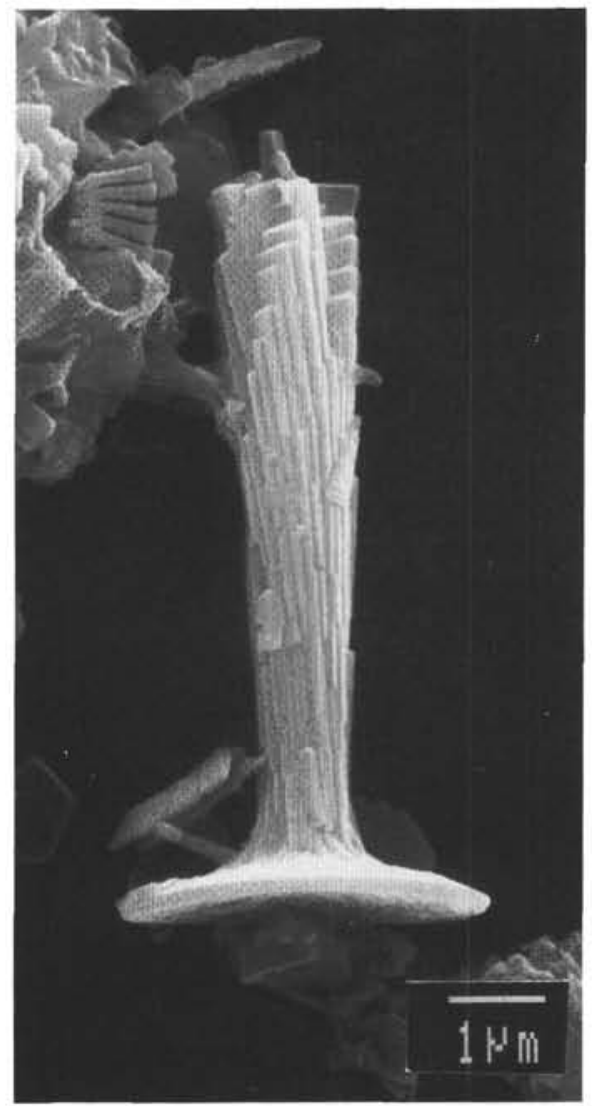

5

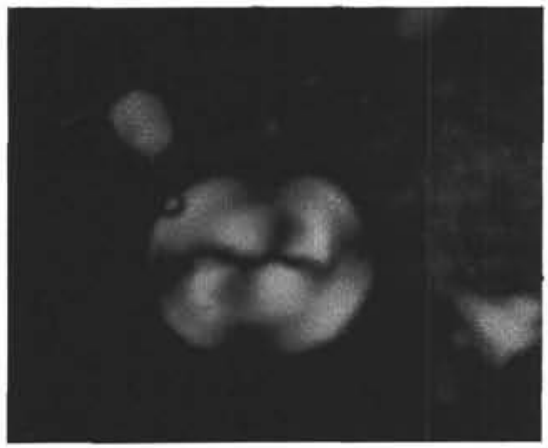

8

Plate 3. 1. $(\times 4500)$ Discosphaera tubifer, Murray and Blackman. Sample $134-828$ A-7H-6, 40-41 cm, cross nicols. 2. ( $\times 7000)$ Emiliania huxleyi, Lohmann, and Calcidiscus leptoporus, Murray and Blackman. Sample 134-831A-2H-2, 29-30 cm, SEM. 3. ( $\times 4500)$ Rhabdosphaera claviger, Murray and Blackman. Sample 134-830A-2H-6, 30-31 cm. 4. (×6500) Pseudoemiliania lacunosa, Kamptner. Sample 134-828A-7H-6, 40-41 cm, SEM. 5. ( $\times 10,000)$ Rhabdosphaera claviger, Murray and Blackman. Sample 134-828A-7H-6, 40-41 cm, SEM. 6. ( $\times 4500)$ Scapholithus fossils, Deflandre. Sample 134-830A-1H-2, 60-61 cm, cross-nicols. 7. Bramletteius serraculoides, Gartner. Sample 134-828B-1R-4, 121-122 cm, phase contrast. 8. $(\times 2800)$ Dictyococcites cf. scrippsae, Bukry and Percival. Sample 134-828B-1R-4, 121-122 cm, cross-nicols. 